UNIVERSIDADE DE SÃO PAULO

FACULDADE DE MEDICINA DE RIBEIRÃO PRETO

DEPARTAMENTO DE BIOQUÍMICA E IMUNOLOGIA

Schistosoma mansoni: Caracterização do perfil de resposta aos estresses oxidativo, térmico e químico

RENATO GRACIANO DE PAULA

Ribeirão Preto 


\section{Schistosoma mansoni: Caracterização do perfil de resposta aos estresses oxidativo, térmico e químico}

Dissertação apresentada à Faculdade de Medicina de Ribeirão Preto da Universidade de São Paulo para obtenção do título de Mestre em Ciências.

Área de Concentração: Bioquímica

Orientador: Prof. Dr. Vanderlei Rodrigues 
AUTORIZO A REPRODUÇÃO E DIVULGAÇÃO TOTAL OU PARCIAL DESTE TRABALHO, POR QUALQUER MEIO CONVENCIONAL OU ELETRÔNICO, PARA FINS DE ESTUDO E PESQUISA, DESDE QUE CITADA A FONTE.

\section{FICHA CATALOGRÁFICA}

De Paula, Renato Graciano

Schistosoma mansoni: Caracterização do perfil de resposta aos estresses oxidativo, térmico e químico. Ribeirão Preto: USP, 2013.

170p. il., $30 \mathrm{~cm}$.

Dissertação apresentada à Faculdade de Medicina de Ribeirão Preto da Universidade de São Paulo, para obtenção de título de Mestre em Ciências. Área de Concentração: Bioquímica.

Orientador: Prof. Dr. Vanderlei Rodrigues

1. Schistosoma mansoni. 2. Sistema Ubiquitina-Proteassoma. 3. Expressão gênica. 


\section{FOLHA DE APROVAÇÃO}

\section{RENATO GRACIANO DE PAULA}

Schistosoma mansoni: Caracterização do perfil de resposta aos estresses oxidativo, térmico e químico.

Dissertação apresentada à Faculdade de Medicina de Ribeirão Preto da Universidade de São Paulo para obtenção do título de Mestre em Ciências. Área de Concentração: Bioquímica.

Aprovada em:

Banca examinadora

Prof. Dr. Instituição:

Julgamento: Assinatura:

Prof. Dr. Instituição:

Julgamento: Assinatura:

Prof. Dr. Instituição:

Julgamento: Assinatura: 
"A menos que modifiquemos nossa maneira de pensar, não seremos capazes de resolver os problemas causados pela forma como nos acostumamos a ver o mundo"

Albert Enstein 


\section{DEDICO}

A Deus,

A minha familia que mesmo estando longe sempre apoiaram $e$ respeitaram minhas decisões. Obrigado por sempre torcerem pelo meu sucesso e me incentivarem.

A minha mãe, Ruti Néia Graciano, pela dedicação, carinho e amor de mãe.

A minha irmã. Bruna Graciano Calassara, uma pessoa especial e que me faz melhor a cada dia.

Aos meus avós, Maria da Penha Silva Graciano e João Simões Graciano, pela excelente criação e pelos valores ensinados.

Aos meus Tios José dos Santos, Gilberto, Gilmar, Lucinéia, Rosa e também Toninho por me apoiar e muitas vezes financiar.

Aos meus primos e primas, muito obrigado por alegrar minha vida. 


\section{AGRADECIMENTOS}

A Deus e a minha família.

Ao grande professor e amigo Dr. Olavo dos Santos Pereira Júnior por ter me introduzido à ciência, pela oportunidade e pelo grande aprendizado durante toda minha iniciação científica. Obrigado por sua amizade e conselhos acadêmicos.

Ao Prof. Dr. Vanderlei Rodrigues, por me receber em seu laboratório e pela confiança depositada em mim durante a execução deste trabalho, pelos conselhos e principalmente pela liberdade para exercer o meu "pensar científico".

À Prof ${ }^{a}$. Dr ${ }^{\mathrm{a}}$. Lizandra Guidi Magalhães, pela amizade sincera, pelas inúmeras discussões, pelo auxílio na correção do trabalho, por ser essa pessoa tão alegre e ao mesmo tempo tão prestativa, sempre pronta a ajudar. Obrigado pela ajuda sempre que precisei.

Às técnicas Elenice Aparecida Macedo e Olinda Mara Brigato, obrigada pelo suporte técnico, imprescindível na realização deste trabalho. Obrigado pelo auxílio nas perfusões e pelo sequenciamento das minhas amostras. Mara, obrigada pela forma dedicada que cuida e mantém o ciclo do $S$. mansoni, bem como pelo auxílio nas perfusões e pelos diversos momentos engraçados que você nos proporciona.

Aos colegas de trabalho do Laboratório de Biologia Molecular de Parasitas: Alice, Enyara, Lizandra, Carla, Érika, Cláudia. Obrigado pelo auxílio durante a execução deste trabalho. Carlinha, embora em outro laboratório, tornava-se sempre presente e pronta a ajudar. Sua alegria e prontidão em ajudar as pessoas é especial e contagiante. Obrigado pelo carinho, pelo auxílio no desenho de primers e sequenciamento de amostras. Claúdia, muito obrigado pela ajuda com RNAi, a qual foi essencial no início para definição do meu trabalho.

A Dr ${ }^{\mathrm{a}}$. Enyara Rezende Morais, inicialmente colega de bancada, mas agora e sempre se tornou uma amiga com a qual eu sei que posso contar em todas as horas que necessitar. Difícil é definir suas inúmeras qualidades, no entanto, suas características mais marcantes são a alegria, gentileza, competência, inteligência e humildade. Muito obrigado por sempre me 
incentivar nos momentos de dúvida, pelos seus conselhos (profissionais e pessoais) e sugestões sempre bem vindas e que contribuíram muito para o início, meio e fim deste trabalho.

A Alice Maria de Magalhães Ornelas (ou se você preferir: Alice Ornelas), meu muito obrigado pela sua amizade sincera e por estar ao meu lado em todos os momentos que precisei. No início, amiga para ouvir os desabafos da adaptação em Ribeirão Preto, os quais muitas das vezes eram compartilhados. Você aos poucos foi se tornando cada vez mais especial e sua amizade verdadeira foi essencial nos momentos que precisei, seus conselhos diante dos momentos mais difíceis (você sabe quais), foram de grande utilidade e sempre me ajudam a ver o outro lado das coisas. Quanto bons momentos, quantas risadas, quantos apelidos criados e compartilhados, quantos delays que me faziam ter medo. Enfim, muito obrigado por tudo tenha certeza de que você ganhou um irmão para vida inteira. Te adoro.

Aos Professores Dr. Célio Lopes Silva, Dr. Hélio Vannucchi, Dr. João Santana da Silva, Dra . Vânia Luiza Deperon Bonato e Dra ${ }^{\mathrm{a}}$. Arlete A. Martins Coelho Castelo, Dr ${ }^{\mathrm{a}}$. Lúcia Helena Faccioli, Dr ${ }^{\mathrm{a}}$. Isis do Carmo Kettelhut e $\mathrm{Dr}^{\mathrm{a}}$. Maria Cristina Roque Barreira por disponibilizarem seus laboratórios para a utilização dos aparelhos imprescindíveis para realização deste trabalho.

Aos docentes do Departamento de Bioquímica e Imunologia por compartilharem seus conhecimentos teóricos, práticos e que, direta ou indiretamente, contribuíram para a minha formação científica.

Aos técnicos Maria D. Seabra Ferreira e José Augusto Maulim do Laboratório de Microscopia Eletrônica (Departamento de Biologia Celular e Molecular e Bioagentes Patogênicos) pelo auxílio no processamento e fotodocumentação das amostras para microscopia.

Às técnicas de laboratório Wendy Martin Rios, Ana Flávia, Ana Masson, Izaíra Tincani Brandão, Lívia e Mônica (Dr. Hélio Vannucchi) e Sandra Maria Oliveira Thomaz pela atenção que sempre tiveram comigo em todos os momentos que solicitei ajuda.

Aos técnicos Vander Cosme Ribeiro da Silva e Lúcia Helena Pacheco, pela alegria proporcionada, seja na hora do café ou almoço no restaurante universitário. 
Aos colegas da pós-graduação da bioquímica, em especial à Lara Aparecida Buffoni Carneiro pela ajuda nos momentos de aluno PAE, pela amizade sincera e pelas risadas e momentos de distração, e claro por incluir as tortinhas no coffee-break do Curso de Inverno da Bioquímica.

Aos meus amigos de graduação e para vida toda por me incentivarem, se alegrarem com minhas conquistas e torcerem tanto pelo meu sucesso. Vocês são essenciais na minha vida, tornando-a mais leve. Muito obrigado por me ensinarem o verdadeiro e real significado da palavra amizade.

As amigas e irmãs da vida toda: Gabriela Tonini Peterle, Lílian Bozzi, Leiliane Bozzi, Liliane Bozzi, Camila Leite Wandermurren, Christyane Bisi Tonini e Jussara Souza pelos muitos momentos de alegria e descontração.

Aos meus amigos de Ribeirão Preto por me incentivarem, se alegrarem com minhas conquistas e torcerem tanto pelo meu sucesso. Muito obrigado ao Malson, André, Amanda, Rafael, Mariana, Alecsandra (Leka), Ana Paula, Camila, Bruno e agora também ao recémchegado amigo de graduação Henrique. Obrigado por se tornarem uma família para mim em Ribeirão.

A Malson Neilson de Lucena pelas inúmeras vezes que me ouviu e procurou me compreender e ajudar. Tenho certeza que ganhei um irmão para vida toda. Sua competência, organização, humildade e alegria de viver são exemplos a serem seguidos.

À Maria Ivone de Campos, pela dedicação e eficiência na secretaria do programa e pelo auxílio em todos os momentos em que precisei da sua ajuda desde o momento da inscrição no mestrado até a minha defesa. Sua competência e prontidão em ajudar são marcantes.

À Veranilde Viana Costa pela forma tão dedicada e zelosa de limpar nosso laboratório e prédio. Obrigado pelos momentos de alegria.

Ao Laboratório de Espectrometria de Massas, Laboratório Nacional de Biociências (LNBIO) no Centro Nacional de Pesquisa em Energia e Materiais (CNPEM) - Campinas - São Paulo pela identificação das amostras proteicas. 
A Coordenação de Aperfeiçoamento de Pessoal de Nível Superior (CAPES) pela concessão da bolsa de mestrado e à Fundação de Amparo à Pesquisa do Estado de São Paulo (FAPESP) pelos auxílios financeiros para realização do projeto de pesquisa, meu sincero agradecimento.

E a todos que direta ou indiretamente contribuíram para que este trabalho fosse concretizado.

Muito obrigado. 


\section{RESUMO}

DE PAULA, R. G. Schistosoma mansoni: Caracterização do perfil de resposta aos estresses oxidativo, térmico e químico, 2013. 170f. Dissertação de Mestrado - Faculdade de Medicina de Ribeirão Preto, Universidade de São Paulo, 2013.

A esquistossomose mansônica é a segunda maior endemia parasitária do mundo em termos de extensão das áreas endêmicas e do número de pessoas infectadas com 200 milhões de pessoas acometidas. Esta doença é causada pelo parasito trematódeo Schistosoma mansoni, o qual apresenta adequados mecanismos de resposta ao estresse envolvendo a regulação da expressão gênica e proteica, reparo ou substituição de moléculas danificadas, recuperação do balanço redox, controle do ciclo celular e apoptose. O sistema ubiquitina- proteassoma é importante para manter a homeostase proteica durante o estresse celular. Inibidores do proteassoma podem interferir em processos como crescimento, progressão do ciclo celular e replicação, e os seus efeitos vem sendo caracterizados em muitos parasitos. Nosso laboratório demonstrou que MG132 reduz o número de esquistossômulos, a carga parasitária e a ovoposição em camundongos infectados com S. mansoni. Neste trabalho, são descritos os efeitos in vitro do estresse oxidativo, choque térmico e estresse químico em vermes adultos de $S$. mansoni. Observou-se alteração no perfil de expressão proteica durante estresse oxidativo e térmico, sendo identificadas dezoito proteínas upreguladas nestas condições. Estas proteínas estão envolvidas em muitas vias intracelulares como dobramento de proteínas, proteólise, ligação a íons cálcio, regulação de proteínas e resposta a estresse. Além disso, o estresse oxidativo gerou mudanças em vermes adultos de $S$. mansoni em processos como produção de ovos, motilidade, morfologia do tegumento, viabilidade e pareamento dos vermes. O estresse químico induzido com Curcumina, IBMX e MG132 aumentou a produção de ROS intracelular e alterou o perfil de expressão de enzimas antioxidantes em $S$. mansoni. As enzimas SmGPxl e SmPGx2 tiveram a expressão aumentada no estresse com Curcumina e IBMX, enquanto que SmSOD e SmTGR foram induzidas no estresse com Curcumina. As enzimas do proteassoma SmHul5 e SmUbp6 tiveram a expressão modulada durante o estresse oxidativo, choque térmico e estresse químico. Em adição, a análise de expressão no ciclo de vida de $S$. mansoni revelou que estes genes apresentam um nível alto de expressão em esporocistos, esquistossômulos e miracídios. Estes resultados sugerem que estas proteínas acessórias do proteassoma participam da resposta ao estresse e desenvolvimento do parasito. O nível de expressão de SmHul5 e SmUbp6 foi cerca 9 e 16 vezes menor em relação ao controle no estresse químico induzido com IBMX, respectivamente, sugerindo a desmontagem do proteassoma. Por outro lado, Curcumina, MG132, estresse oxidativo e choque térmico aumentaram o nível de expressão de SmHul5 e SmUbp6. Além disso, o nível de expressão da proteína de maturação do proteassoma (SmPOMP) aumentou no estresse com Curcumina, MG132 e estresse oxidativo, sugerindo a síntese de novas populações de proteassoma. Em relação ao estresse oxidativo, nós demonstramos o aumento no nível proteico de proteassoma $20 \mathrm{~S}$ e da subunidade alfa-3 do proteassoma sugerindo que em $S$. mansoni as proteínas oxidadas são degradadas pelo proteassoma 20S. Além do mais, nós observamos que vermes adultos de $S$. mansoni parecem utilizar mecanismos de resposta similares para diferentes estresses. Nossos resultados demonstraram que o estresse oxidativo, choque térmico e estresse químico modificam o perfil de expressão de genes relacionados ao sistema ubiquitina-proteassoma e sugerem que o proteassoma é importante para as respostas celulares ao estresse neste parasito. 


\begin{abstract}
DE PAULA, R. G. Schistosoma mansoni: Caracterização do perfil de resposta aos estresses oxidativo, térmico e químico, 2013. 170f. Dissertação de Mestrado - Faculdade de Medicina de Ribeirão Preto, Universidade de São Paulo, 2013.

Schistosomiasis is a neglected tropical disease caused by blood flukes (genus Schistosoma) and affecting 200 million people worldwide. This disease continues to rank, following malaria, at the second position of the world's parasitic diseases in terms of the extent of endemic areas and the number of infected people. There are different types of stress and the organisms have many mechanisms to respond to these stressor agents. The responses involve the regulation of gene and protein expression and consist in events such as repair or substitution of damaged molecules, recovery of redox balance, cell cycle control and apoptosis. The proteasomal system is important to support the protein homeostasis during the cellular stress. Effect of proteasome inhibitors has been described in many protozoans, either inhibiting growth or cell cycle progression, or blocking replication. Our laboratory's results have shown that MG132 reduces the number of lung stage schistosomula, the worm burden and consequently decreases oviposition in $S$. mansoni-infected mice. Here, we describe the in vitro effects of oxidative stress, heat shock and chemical stress in $S$. mansoni adult worms. We report that the oxidative stress and heat shock cause drastic changes in the protein profile of $S$. mansoni adult worms, and we identified a total of eighteen upregulated proteins in these conditions. These proteins are involved with many intracellular pathways as protein folding, proteolysis, calcium ion binding, regulator proteins and stress response. In addition, oxidative stress induced with $\mathrm{H}_{2} \mathrm{O}_{2}$ generated significative changes in the adult worms concerning process such as egg production, motor activity, tegument morphology, viability and pairing of worms. Chemical stress induced with Curcumin, IBMX and MG132 increases ROS production and changes the gene expression profile of antioxidant enzymes of $S$. mansoni adult worms. The enzymes SmGPxl and SmGPx2 were upregulated in Curcumin and IBMXinduced chemical stress, and both SmSOD and SmTGR were upregulated- Curcumin. The proteasomal enzymes SmHul5 and SmUbp6 had their gene expression modified during oxidative stress, heat shock and chemical stress. Besides of, expression analyses in the $S$. mansoni life cycle indicate that genes are different express in sporocyst, schistosomula and miracidia. These results suggest these accessory proteins proteasome participates of stress response and parasite development. The expression level of SmHul5 and SmUbp6 were 16 and 9 times less than the control in chemical stress induced by IBMX, and we suggest that these results are due to the proteasome disassembling. On the other hand, Curcumin, MG132, oxidative stress e heat shock increases the expression of SmHul5 and SmUbp6. Furthermore, the expression level of maturation proteasome protein (SmPOMP) increases in stress induced by Curcumin, MG132 and oxidative stress suggesting new proteasome synthesis. In addition, we demonstrate increase the both $20 \mathrm{~S}$ level and alpha-3 subunit proteasome in the oxidative stress, suggesting that in $S$. mansoni oxidized protein formed due to oxidative damage are degrade by proteasome $20 \mathrm{~S}$. We observed that $S$. mansoni adult worms utilize similar mechanisms to respond different stresses. Ours results demonstrate that oxidative stress, heat shock and chemical stress modified the expression profile of genes related with the ubiquitinproteasome system and suggest that the proteasome is important to responses the cellular stresses in the parasite.
\end{abstract}




\section{ABREVIATURAS}

BCIP - 5-Bromo-4-chloro-3-indolyl phosphate

BLAST - Basic Local Alignment Search Tool

cDNA - DNA complementar

DEPC - Dietilpirocarbonato

DMSO - Dimetilsulfóxido

dNTP - Desoxonucleosídeo trifosfatado

DTT - Ditiotreitol

GSH - Glutationa

HEPES - 2-4-(2-hidroxietil)-pperazinil-(1)-ácido etanosulfônico

HSPs - Proteínas de Choque Térmico

HSR - Resposta a choque térmico

IBMX - 3-isobutil-1-metilxantina

MEGA - Molecular Evolutionary Genetics Analysis

MG132 - Z-Leu-Leu-Leu-al

MTT - Brometo de 3-4,5-dimetiltiazol-2-il-2,5-difenil

NBT - Nitrotetrazolium Blue chloride

NCBI - National Center for Biotechnology Information

ORF - Open reading frame

PBS - Solução salina tamponada com fosfato

PFAM - Protein family database

ROS - Reactive oxygen species (espécies reativas de oxigênio)

RPMI - Roswell Park Memorial Institute

RT-PCR - Transcrição Reversa- Reação em cadeia da polimerase

SDS - Dodecil sulfato de sódio

SDS-PAGE - Sodium dodecyl sulfate polyacrylamide gel electrophoresis

TBS-T - TBS- Tween

UPR - Resposta às proteínas dobradas incorretamente 


\section{LISTA DE TABELAS}

Tabela 1. Sequências gênicas referentes a enzimas acessórias ao proteassoma de S. mansoni e genes marcadores de estresse celular..... 52

Tabela 2. Oligonucleotídeos iniciadores para amplificação dos genes referentes a enzimas acessórias ao proteassoma de S. mansoni e genes marcadores de estresse celular...... .53

Tabela 3. Conservação da proteína Hul5 nos diferentes organismos. .66

Tabela 4. Conservação da proteína Ubp6 nos diferentes organismos. . .70

Tabela 5. Efeito in vitro do estresse oxidativo com peróxido de hidrogênio em vermes adultos de S. mansoni. .78

Tabela 6. Proteínas identificadas após estresse oxidativo e térmico. 107

Tabela 7. Proteínas upreguladas no estresse oxidativo e térmico e Fold change da expressão proteica. 


\section{LISTA DE FIGURAS}

Figura 1. Distribuição global da Esquistossomose .22

Figura 2. Diagrama esquemático do ciclo de vida do parasito $S$. mansoni......

Figura 3. Sistema Ubiquitina-Proteassoma e via de ubiquitinação de substratos para degradação proteassomal.

Figura 4. Ciclo de degradação proteassomal e as atividades de Hul5 e Ubp6.

Figura 5. Estresse oxidativo: balanço entre espécies reativas de oxigênio (ROS) e antioxidantes (AOX).

Figura 6. Reconhecimento de proteínas oxidadas para degradação pelo sistema ubiquitinaproteassoma (UPP) .38

Figura 7. Sequência de aminoácidos predita para SmHul5 (Smp_130650) .65

Figura 8. Alinhamento da sequência da proteína SmHul5 (Smp_130650) com sequências ortólogas.

Figura 9. Filogenia entre sequências homólogas à proteína SmHul5 (Smp_130650).... .68

Figura 10. Sequência de aminoácidos predita para SmUbp6 (Smp_084740). . .68

Figura 11. Alinhamento da sequência da proteína SmUbp6 (Smp_084740) com sequências ortólogas

Figura 12. Filogenia entre sequências homólogas à proteína SmUbp6 (Smp_084740)..........70

Figura 13. Organização genômica de SmHul5 (Smp_130650)................................................71

Figura 14. Organização genômica de SmUbp6 (Smp_084740).............................................72

Figura 15. Validação dos oligonucleotídeos iniciadores dos genes referentes a enzimas acessórias ao proteassoma de $S$. mansoni e proteína de maturação do proteassoma. . .73

Figura 16. Expressão do gene SmHul5 nas fases evolutivas de S. mansoni .74

Figura 17. Expressão do gene SmUbp6 nas fases evolutivas de $S$. mansoni. .76

Figura 18. Efeito in vitro de estresse oxidativo com peróxido de hidrogênio na viabilidade de vermes adultos de $S$. mansoni....

Figura 19. Efeito do tempo na viabilidade de vermes adultos de $S$. mansoni submetidos a estresse oxidativo.

Figura 20. Produção de ovos de vermes adultos de $S$. mansoni submetidos a estresse oxidativo .83

Figura 21. Microscopia eletrônica de varredura do tegumento de vermes adultos de $S$. mansoni. 
Figura 22. Microscopia eletrônica de varredura do tegumento de vermes adultos machos de $S$. mansoni tratados com $10 \mu \mathrm{M}$ de Praziquantel por 24 horas.

Figura 23. Microscopia eletrônica de varredura do tegumento de vermes adultos fêmeas de $S$. mansoni tratados com $10 \mu \mathrm{M}$ de Praziquantel por 24 horas.

Figura 24. Microscopia eletrônica de varredura do tegumento de vermes adultos de $S$. mansoni tratados com $800 \mu \mathrm{M}$ de peróxido de hidrogênio $\left(\mathrm{H}_{2} \mathrm{O}_{2}\right)$ por 24 horas .88

Figura 25. Microscopia eletrônica de varredura do tegumento de vermes adultos de $S$. mansoni tratados com $1 \mathrm{mM}$ de peróxido de hidrogênio $\left(\mathrm{H}_{2} \mathrm{O}_{2}\right)$ por 24 horas.

Figura 26. Expressão dos genes SmHul5 e SmUbp6 após estresse oxidativo. .90

Figura 27. Detecção de proteassoma 20S durante estresse oxidativo. .91

Figura 28. Produção de ROS em vermes adultos de S. mansoni após estresse químico..... .93

Figura 29. Expressão de genes do sistema de defesa antioxidante de $S$. mansoni no estresse químico.

Figura 30. Expressão de genes para proteínas de choque térmico no estresse químico .95

Figura 31. Expressão do gene $S m H u l 5$ após estresse químico com IBMX. . .97

Figura 32. Expressão do gene SmUbp6 após estresse químico com IBMX .98

Figura 33. Expressão dos genes $\mathrm{SmHul5}$ e SmUbp6 após estresse químico com Curcumina e MG132.

Figura 34. Expressão diferencial dos genes SmHul5 e SmUbp6 após estresse térmico. 100

Figura 35. Expressão de SmPOMP após estresse químico e estresse oxidativo. 102

Figura 36. Viabilidade de vermes adultos de $S$. mansoni após indução de estresse térmico.103

Figura 37. Proteínas diferencialmente expressas na condição de estresse oxidativo 105

Figura 38. Proteínas diferencialmente expressas na condição de estresse térmico. 106

Figura 39. Categorização das proteínas diferencialmente expressas no estresse oxidativo quanto a Processos Biológicos 114

Figura 40. Categorização das proteínas diferencialmente expressas no estresse oxidativo quanto a Função Molecular. 115

Figura 41. Categorização das proteínas diferencialmente expressas no estresse oxidativo quanto a Componente Celular.

Figura 42. Categorização das proteínas diferencialmente expressas no estrese térmico. 116 


\section{SUMÁRIO}

1. Introdução.......................................................................................................................21

1.1. Histórico e epidemiologia da Esquistossomose no Brasil.........................................21

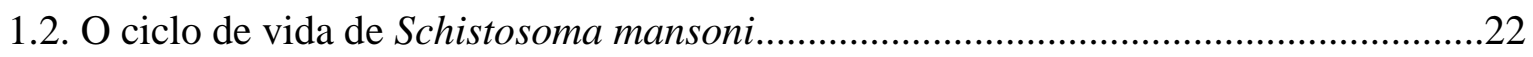

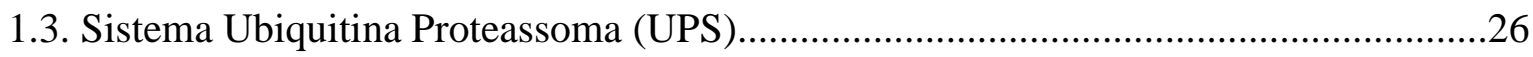

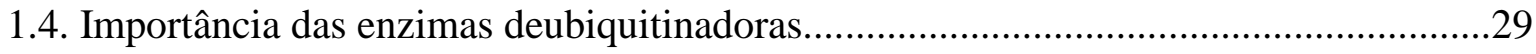

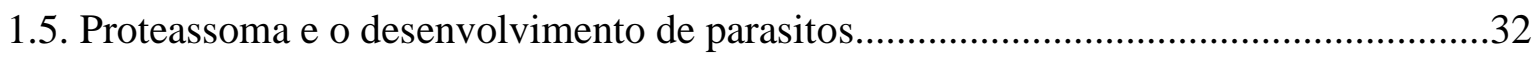

1.6. Estresse celular versus Sistema Ubiquitina-Proteassoma.............................................

1.7. Schistosoma mansoni: visão geral dos mecanismos de resposta ao estresse..................38

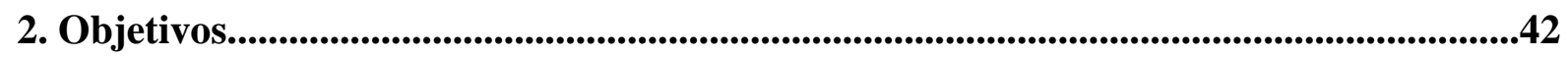

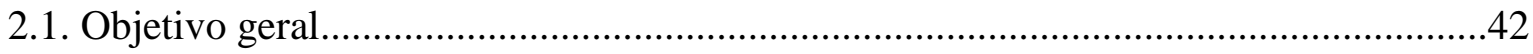

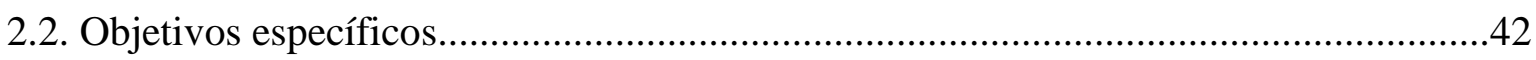

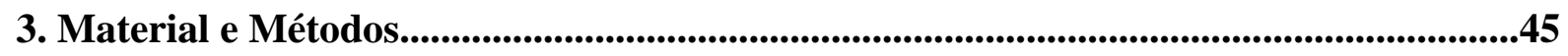

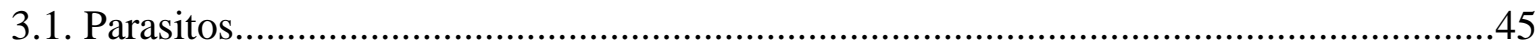

3.2. Obtenção de vermes adultos de $S$. mansoni ...................................................................

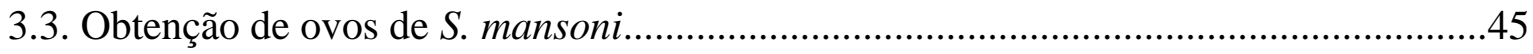

3.4. Obtenção de cercárias e transformação mecânica de cercárias em

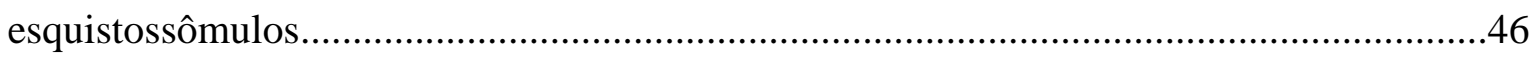

3.5. Obtenção de miracídios e esporocistos de S. mansoni................................................47

3.6. Ensaios in vitro de estresse do proteassoma de $S$. mansoni.........................................47

3.6.1. Estresse químico.........................................................................................47

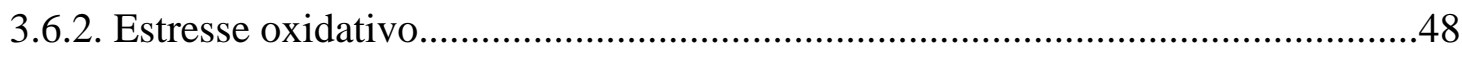

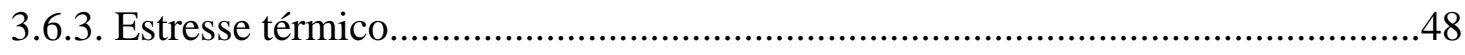

3.7. Viabilidade de vermes adultos de S. mansoni ............................................................

3.8. Produção de espécies reativas de oxigênio (ROS) após estresse químico.....................49

3.9. Microscopia eletrônica de varredura para avaliação de danos no tegumento de vermes

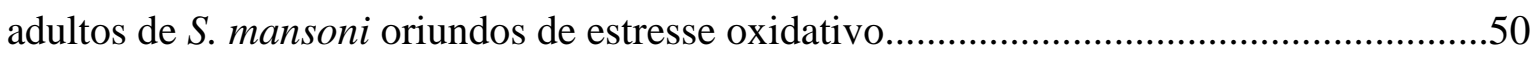

3.10. Análises de bioinformática para os genes SmHul5 e SmUbp6..................................51 
3.10.1. Banco de dados e análises in silico

3.10.2. Idealização dos oligonucleotídeos iniciadores para SmHul5, SmUbp6 e genes

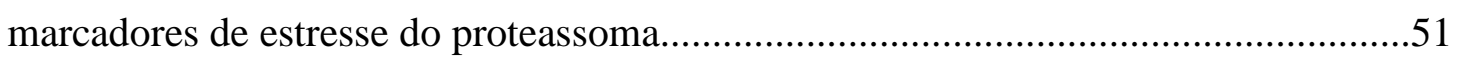

3.10.3. Análise da estrutura genômica dos genes SmHul5 e SmUbp6..........................53

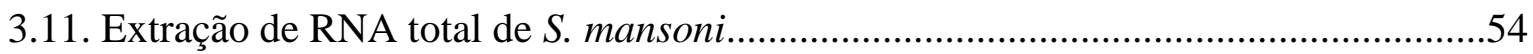

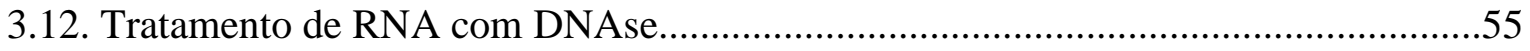

3.13. Síntese do DNA complementar pela técnica de transcrição reserva (RT)..................55

3.14. Validação dos oligonucleotídeos iniciadores para os genes SmHul5 e SmUbp6........55

3.15. Sequenciamento dos nucleotídeos e análise computacional das sequências................56

3.16. Perfil de expressão de SmHul5 e SmUbp6 no ciclo de vida de S. mansoni e em diferentes condições de estresse do proteassoma.................................................................56

3.17. Perfil de expressão de SmGPx1, SmGPx2, SmSOD, SmTGR, SmHsp70 e SmHsp40

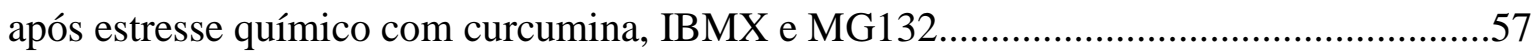

3.18. Obtenção do extrato proteico solúvel total de vermes adultos de $S$. mansoni..............58

3.19. Western Blotting para detecção de subunidades $\alpha$ do proteassoma.............................58

3.20. Proteoma para estresse oxidativo e estresse térmico..................................................59

3.20.1. Preparo das amostras e reidratação das "strips "...............................................59

3.20.2. Focalização isoelétrica...................................................................................60

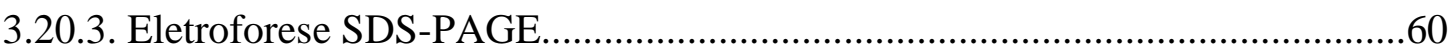

3.21. Identificação de proteínas por Espectrometria de massas................................................61

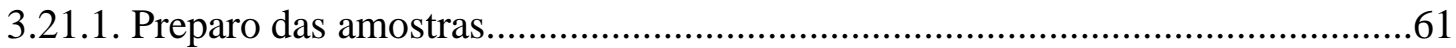

3.21.2. Espectrometria das massas......................................................................62

3.22. Categorização das proteínas diferencialmente expressas.............................................62

4. Resultados...................................................................................................................................................65

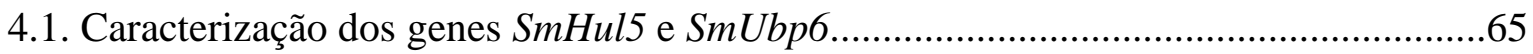

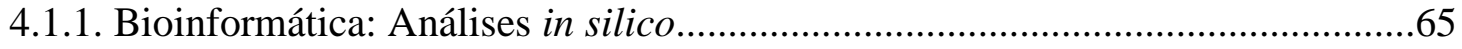

4.1.2. Validação dos oligonucleotídeos iniciadores por PCR.....................................72

4.1.3. Perfil de expressão de SmHul5 e SmUbp6 no ciclo evolutivo de $S$.

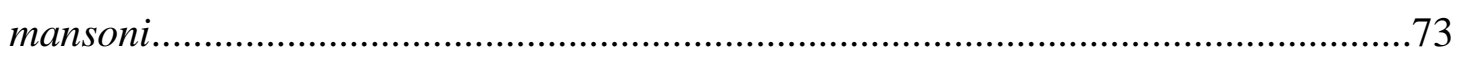

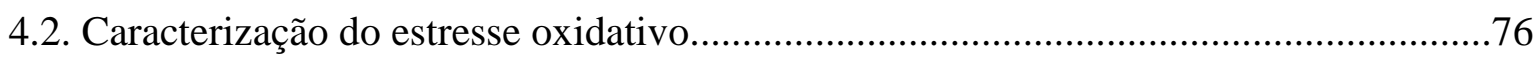

4.2.1. Resposta in vitro ao estresse oxidativo............................................................76

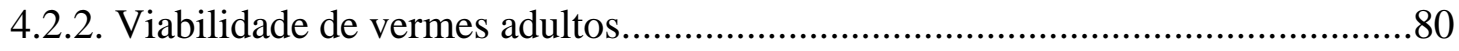


4.2.3. Produção de ovos.

4.2.4. Microscopia eletrônica de varredura para avaliação de danos no tegumento de vermes adultos de $S$. mansoni oriundos de estresse oxidativo.

4.2.5. Perfil de expressão de SmHul5 e SmUbp6 no estresse oxidativo.

4.2.6. Western blotting para detecção de proteassoma $20 \mathrm{~S}$ em extrato bruto de vermes adultos oriundos de estresse oxidativo .90

4.3. Caracterização do estresse químico e térmico. .92

4.3.1. Determinação da produção de espécies reativas de oxigênio (ROS) no estresse químico com Curcumina, IBMX e MG132.

4.3.2. Análise de expressão de genes do sistema de defesa de S. mansoni mediante condição de estresse químico. . .93

4.3.3. Perfil de expressão de SmHul5 e SmUbp6 no estresse químico e térmico. .96

4.3.3.1. Estresse químico .96

4.3.3.2. Estresse térmico 100

4.3.4. Perfil de expressão de SmPOMP em diferentes condições de estresse do proteassoma de S. mansoni 101

4.4. Resposta in vitro ao estresse térmico.

4.5. Perfil de expressão proteica de vermes adultos de $S$. mansoni em resposta a estresse oxidativo e térmico. 104

4.6. Categorização das proteínas diferencialmente expressas. 113 4.6.1. Estresse oxidativo 113

4.6.2. Estresse térmico 116

\section{Discussão.}

5.1. Caracterização dos genes $\mathrm{SmHul5}$ e SmUbp6

5.2. Perfil de expressão de SmHul5 e SmUbp6 após estresse químico, oxidativo e térmico.

5.3. Caracterização do estresse oxidativo. 126

5.4. Determinação da produção de espécies reativas de oxigênio (ROS) no estresse químico com Curcumina, IBMX e MG132.

5.5. Perfil de expressão de proteínas de vermes adultos de S. mansoni em resposta a estresse oxidativo e térmico. 


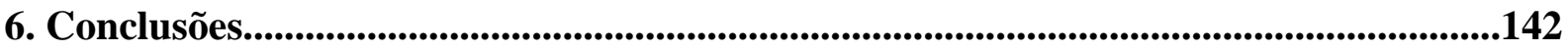

7. Perspectivas Futuras......................................................................................................144

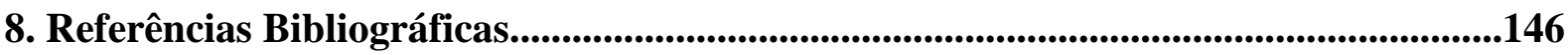




\section{Introdução}




\section{Introdução}

\subsection{Histórico e epidemiologia da Esquistossomose no Brasil}

A esquistossomose mansônica é uma doença infecto-parasitária de veiculação hídrica principalmente em áreas rurais (MARTINS JÚNIOR; BARRETO, 2003; MACCONNACHIE, 2012), causada pelo trematódeo Schistosoma mansoni, sendo o homem o seu hospedeiro definitivo (FUNASA, 2002). No mundo, estima-se que existam mais de 207 milhões de pessoas infectadas, das quais 120 milhões sofrem com os sintomas clínicos da parasitose e 779 milhões vivem em áreas com risco de infecção. Além disso, existem 20 milhões de indivíduos com alta morbidade e, anualmente, ocorrem 280 mil mortes devido a esta parasitose (VAN DER WERF et al, 2003; KING et al., 2005; STEINMANN et al., 2006; McDONALD et al, 2010). Segundo Chitsulo e colaboradores (2000) 85\% do número de pessoas infectadas estão no continente africano, onde os esforços para o controle da doença são ineficazes.

Acredita-se que a esquistossomose mansônica tenha sido trazida da África para o Brasil no século XVI, nos primórdios da colonização europeia, em virtude do tráfico de escravos oriundos de regiões de alta endemicidade da doença (MAGALHAES; DIAS, 1944; PRATA, 2008). Estima-se que no Brasil exista aproximadamente 8 a 10 milhões de indivíduos infectados (AMARAL; PORTO, 1994), fazendo desta doença um dos mais sérios problemas de saúde pública (COURA; AMARAL, 2004). Nas regiões Nordeste e Sudeste a parasitose é amplamente distribuída, enquanto que nas regiões Norte e Sul as áreas endêmicas são mais dispersas e isoladas (TELES, 2005). Os estados da Bahia e Minas Gerais correspondem, segundo o Ministério da Saúde, por $70 \%$ dos casos da doença no país (RODRIGUES; LOUZADA, 2003). As áreas endêmicas estão localizadas nos estados do Maranhão, Pará, Rio Grande do Norte, Paraíba, Pernambuco, Alagoas, Sergipe, Bahia, Minas Gerais, Espírito Santo e na cidade do Rio de Janeiro (SOUZA et al., 2001).

O parasito S. mansoni pertence à subclasse Digenea (Platyhelminthes, Neodermata, Trematoda), a qual está entre os maiores grupos de parasitos que alcançaram sucesso evolutivo (OLSON et al., 2003). A Superfamília Schistosomatoidea compreende os trematódeos parasitos do sangue do homem e de vertebrados inferiores englobando indivíduos monóicos e dióicos, e que tem cercárias com cauda bifurcada. A família Schistosomatidae pode ser dividida em duas subfamílias: Bilharziellinae (sem dimorfismo sexual) e Schistosominae (com dimorfismo sexual) (PESSOA, 1969). Dentro do gênero Schistosoma as 
principais espécies que infectam o homem são: $S$. intercalatum e $S$. haematobuim (África), $S$. mekongi (Índia), S. mansoni (América, África, Antilhas) e S. japoniucum (Indonésia, China e Filipinas) (PESSOA, 1969; REY, 2001) (Figura 1).

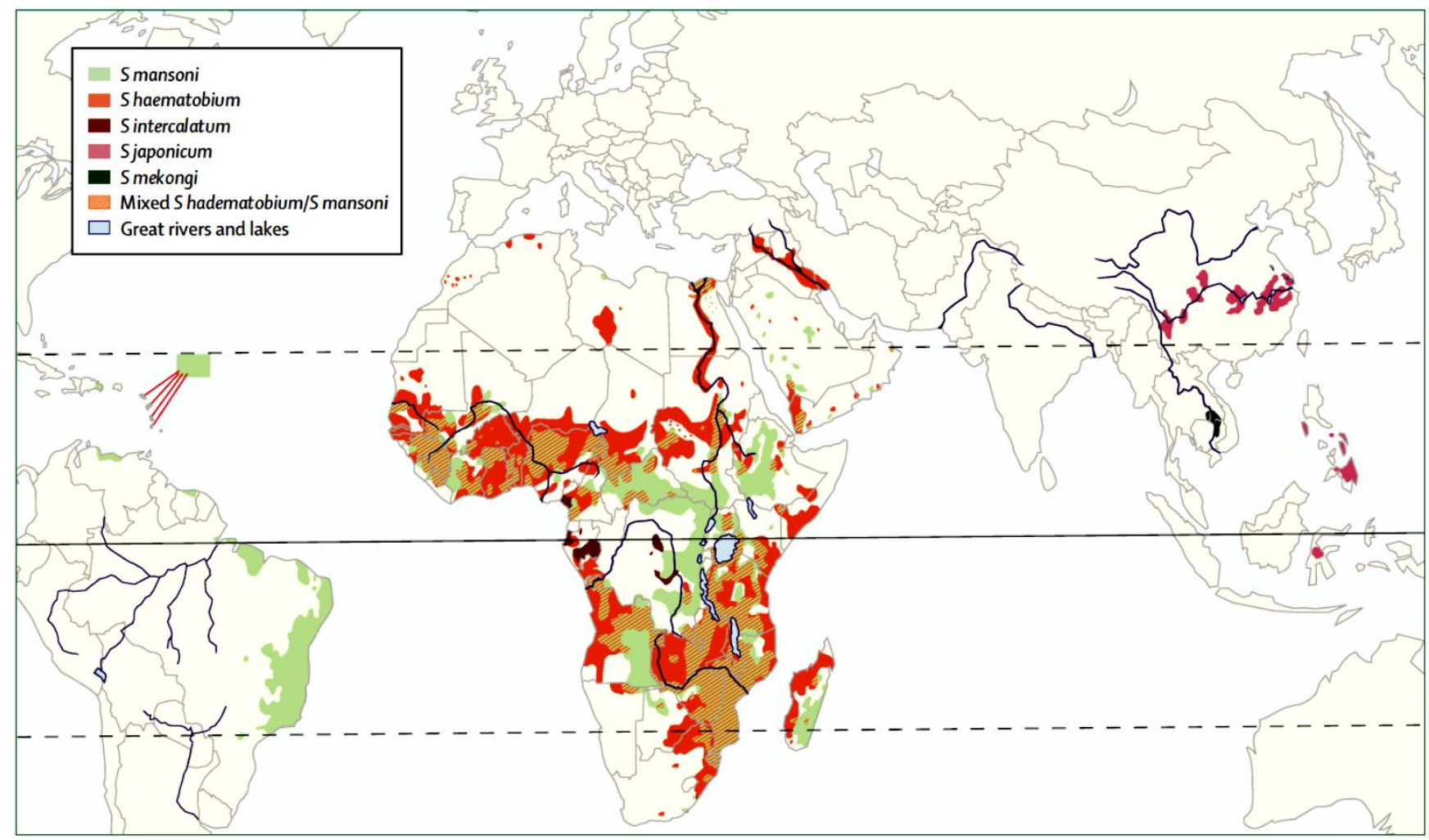

Figura 1. Distribuição global da Esquistossomose. GRYSEELS, B.; POLMAN, K.; CLERINX, J.; KESTENS, L. Human schistosomiasis. Lancet, v. 368, p. 1106-1118, 2006.

A distribuição geográfica de $S$. mansoni é muitas vezes condicionada pela presença de seus hospedeiros intermediários (moluscos do gênero Biomphalaria). Dentre as 10 espécies e uma subespécie do gênero Biomphalaria descritas, três delas são hospedeiras naturais para $S$. mansoni (B. glabrata, B. tenagophila e B. straminea) e duas (B. amazonica e B. peregrina) são consideradas hospedeiras potenciais por terem sido somente infectadas experimentalmente (PARAENSE, 1986).

\subsection{O ciclo de vida de Schistosoma mansoni}

Os vermes adultos de S. mansoni localizam-se no interior dos vasos sanguíneos, habitando preferencialmente as vênulas da parede do intestino grosso e ramificações das veias mesentéricas - causando uma infecção denominada esquistossomose mansônica. O ciclo de 
vida deste parasito é heteroxeno, ou seja, necessita de um hospedeiro intermediário (reprodução assexuada) e um hospedeiro definitivo (reprodução sexuada) (SCHNEIDER; ZELCK, 2001) (Figura 2). Estes helmintos apresentam acentuado dimorfismo sexual, sendo a fêmea delgada e cilíndrica, enquanto o macho possui um corpo mais largo com uma cavidade, o canal ginecóforo, o qual serve de abrigo para a fêmea durante a cópula (REY, 2001).

As fêmeas do parasito põem seus ovos no interior dos vasos sanguíneos, os quais posteriormente atravessam a mucosa intestinal sendo eliminados nas fezes. Na água, os ovos viáveis eclodem, liberando pequenas formas larvais, os miracídios (REY, 2001), que nadam ativamente na água em busca de seu hospedeiro intermediário (PASSOS et al., 1998). A penetração dos miracídios nos moluscos ocorre preferencialmente pela região das antenas ou pé, sendo o reconhecimento do caramujo, provavelmente controlado por dois tipos de respostas: 1) o miracídio responde a estímulos físicos do ambiente ou 2) reconhecimento de estímulos químicos originados pelo molusco (KAPP et al., 2003).

Após penetrar no hospedeiro intermediário, o miracídio dá início aos estágios posteriores de desenvolvimento. As células germinativas presentes no interior do miracídio multiplicam-se e dão origem a um esporocisto mãe, que se divide formando esporocistos filhos, os quais são liberados do esporocisto mãe e migram até a glândula digestiva (hepatopâncreas) do molusco, onde ocorre a formação das inúmeras cercárias (GRYSEELS et al., 2006) cerca de 20 a 30 dias após a infecção do hospedeiro intermediário (COELHO, 1957; PAN, 1996). As cercárias formadas migram para a região da pseudobrânquia do molusco, onde provocam a formação de pequenas vesículas no tegumento dos moluscos. O rompimento das vesículas libera as cercárias para o exterior. Os moluscos infectados liberam cercárias de forma intermitente, sendo a luz e a temperatura fatores imprescindíveis para a eliminação das larvas (REY, 2001). 


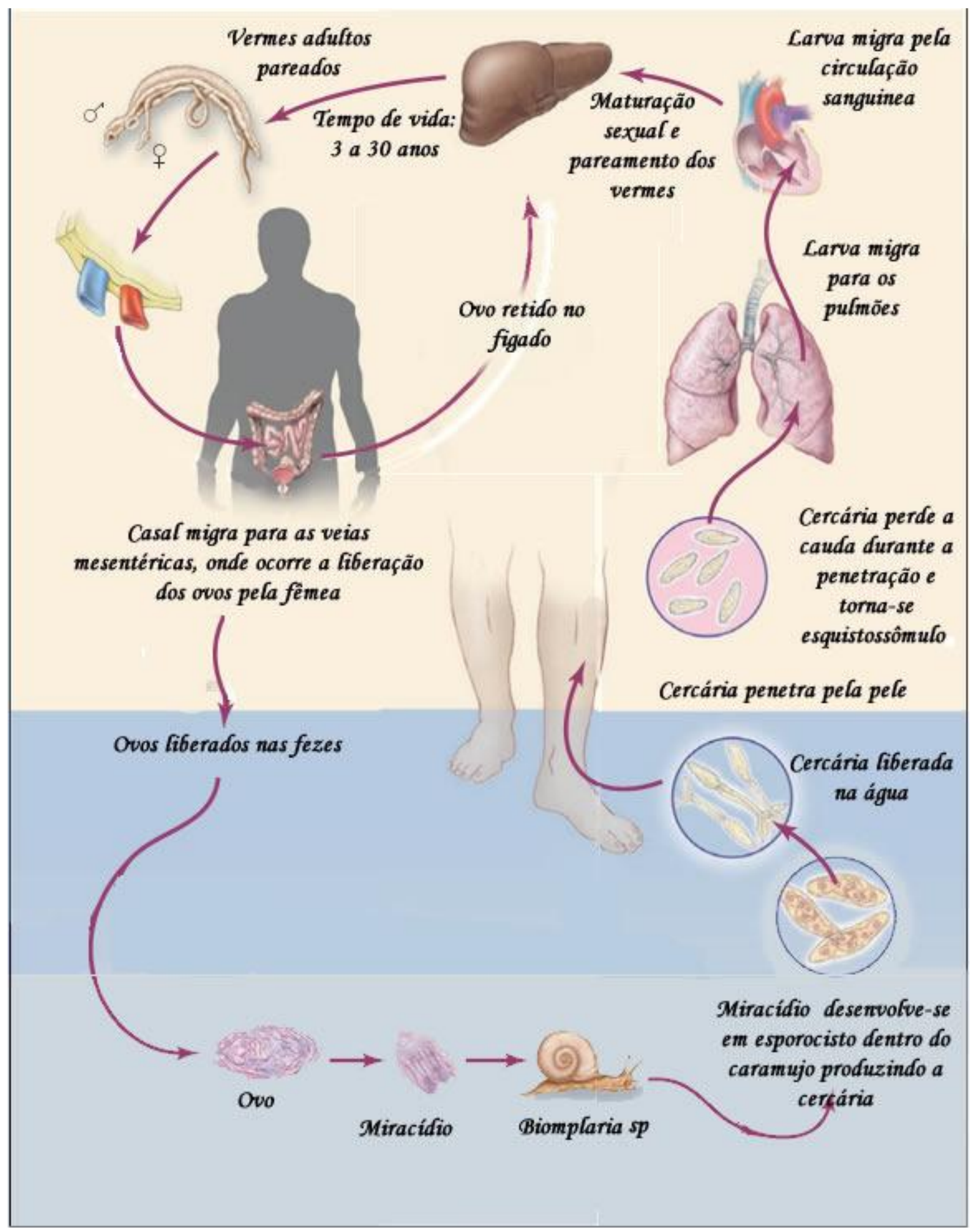

Figura 2. Diagrama esquemático do ciclo de vida do parasito $S$. mansoni. Dentro do seu hospedeiro vertebrado, os esquistossômulos dão origem a parasitas exclusivamente maduros os quais se acasalam e produzem ovos que são liberados para o meio aquático. Os ovos eclodem e liberam os miracídios, esses penetram nos caramujos dando origem a numerosos esporocistos, os quais culminam com a liberação de cercárias, a forma infectante para o hospedeiro vertebrado. Adaptado de Toward the Elimination of Schistosomiasis. KING, C. H., (2009). 
Após a eliminação, as cercárias nadam ativamente na tentativa de encontrarem um hospedeiro definitivo viável para a penetração. Seis pares de glândulas (glândulas de penetração) liberam proteases que permitem as cercárias penetrar toda camada córnea da pele do hospedeiro. Durante a penetração no hospedeiro definitivo, as cercárias perdem a cauda transformando-se em esquistossômulos. Essa transformação é acompanhada por mudanças dramáticas na fisiologia e bioquímica dos parasitos (GOBERT et al., 2007). He e colaboradores (2002) demonstram que aproximadamente 90\% dos esquistossômulos de S. mansoni ainda estão na epiderme após 24 horas. Após a passagem pela epiderme, os esquistossômulos migram para as veias da derme, e ao encontrar a artéria pulmonar estes parasitas são levados até os pulmões. O tempo de chegada e o período de permanência nos pulmões ainda não são claros, mas pesquisas demonstram a presença destes parasitos nos pulmões após 5-6 dias da infecção (GUI et al, 1995). Por volta do $8^{\circ}-15^{\circ}$ dia de infecção, os esquistossômulos deixam os pulmões migram para a circulação venosa e seguem ao sistema porta-hepático, no qual ocorre à maturação sexual e o acasalamento dos parasitos machos e fêmeas. Os casais de vermes migram então unidos em sentido contrário ao fluxo sanguíneo para o seu nicho final nas veias mesentéricas onde as fêmeas acasaladas iniciam a ovoposição, com média de 300 ovos por dia (MOORE; SANDGROUND, 1956; PELLEGRINO; COELHO, 1978). Da submucosa intestinal, parte dos ovos chegam à luz, sendo excretados com as fezes, completando o ciclo do parasito (REY, 2001; GRYSEELS et al., 2006).

Muitos dos ovos não atingem o intestino, sendo armazenados no fígado, onde são responsáveis pela formação de granulomas que podem levar à fibrose e hipertensão portal com todas as suas complicações na fase crônica da doença (DEWALICK et al., 2011). Os ovos de S. mansoni são considerados o principal causa de patologia da esquistossomose por induzirem uma forte resposta imunológica pelo hospedeiro (STADECKER, 1992; DEWALICK et al., 2011). Entretanto, apesar da indução de uma resposta imunológica, o parasita é capaz de sobreviver por vários anos, no sistema vascular do hospedeiro, exposto aos mecanismos imunológicos sem aparente dano, através de mecanismos de evasão. Isso pode ser atribuído, em parte, à expressão diferencial de antígenos que ocorre durante a maturação do verme (SNARY et al., 1980), bem como ao desenvolvimento de uma dupla membrana externa, constantemente renovada (HOCKLEY, 1973; WILSON; BARNES, 1974). Além disso, outros mecanismos podem estar relacionados com a evasão da resposta imune, tais como, a aquisição de proteínas do hospedeiro como: 1) antígenos dos grupos sanguíneos (GOLDRING et al., 1976), 2) antígenos do complexo principal de histocompatibilidade I e II (SHER et al., 1978), 3) proteínas inativadoras do sistema complemento (PEARCE et al., 
1990) e a síntese de algumas proteínas que bloqueiam a ação de determinados componentes imunitários (LACLETTE et al., 1992; GHENDLER et al., 1994; PARIZADE et al., 1994) parecem ser utilizadas pelo parasita como estratégia de defesa.

O tratamento para esquistossomose é realizado com a droga Praziquantel, a única droga utilizada no tratamento de todas as formas de esquistossomose (CIOLI; PICAMATTOCCIA, 1995; CIOLI et al., 2004). No entanto, este medicamento apresenta algumas restrições, visto que não previne reinfecções e é ineficaz contra formas juvenis do parasito. Além disso, tem sido relatado o desenvolvimento de linhagens resistentes ao tratamento com Praziquantel (ISMAIL et al., 1999). Este fato tem alertado a comunidade científica para pesquisa e desenvolvimento de novas drogas com baixo custo contra a esquistossomose (ENGELS et al., 2002; SOLIMAN; IBRAHIM, 2005).

O desenvolvimento de $S$. mansoni ocorre como resultado da expressão coordenada de um conjunto de genes distintos, necessários para as alterações bioquímicas e adaptações morfológicas observadas durante o ciclo de vida. Desta forma, o conhecimento dos genes e dos mecanismos que controlam a sua expressão, permitirão uma melhor compreensão de como o parasito está programado para viver em ambientes tão distintos. O conhecimento molecular também poderá permitir novos modelos de investigação de moléculas importantes que servirão de base para a estruturação de novas drogas quimioterápicas, que reduziriam os efeitos patológicos da doença na sua forma crônica, bem como de futuras vacinas, que poderiam resultar numa ação de desencadeamento da resposta imune protetora, ou num bloqueio do desenvolvimento do parasita no hospedeiro vertebrado.

\subsection{Sistema Ubiquitina Proteassoma (UPS)}

Em células eucarióticas, o "turnover" de proteínas intracelulares é mediado principalmente pelo sistema ubiquitina-proteassoma (GOLDBERG et al., 1997). Esta via proteolítica desempenha papel fundamental em muitos processos biológicos, sendo responsável, por exemplo, por permitir a progressão do ciclo celular, apoptose e angiogênese, uma vez que controla a degradação de muitas proteínas envolvidas nestes processos celulares (PICKART; EDDINS, 2004; CSIZMADIA et al., 2010). Pelo fato, desta via ser fundamental para a sobrevivência e proliferação celular, nos últimos anos, ela tornou-se um importante alvo molecular de terapia para o câncer (LANDIS-PIWOWAR et al., 2006; RICHARDSON et al., 2006). 
O proteassoma 26S, é uma protease multicatalítica composta por dois subcomplexos: o núcleo 20S, o qual é responsável pela atividade catalítica, e a partícula regulatória 19S (GLICKMAN; CIECHANOVER et al., 2002). O núcleo catalítico $20 \mathrm{~S}$ é uma estrutura em barril composta de quatro anéis empilhados, sendo dois externos - anéis $\alpha$ (alfa) e dois internos - anéis $\beta$ (beta) idênticos (COUX et al., 1996). Cada um dos anéis pertencentes à partícula 20S é formado por sete subunidades distintas, dando ao complexo 20S uma estrutura geral de $\alpha_{1-7} \beta_{1-7} \beta_{1-7} \alpha_{1-7}$ (SCHAUER et al. 1993; KOPP et al., 1993). A partícula 19S é formada por duas subestruturas: uma base, composta por seis subunidades ATPásicas pertencentes a família AAA, que interagem com as subunidades $\alpha$ (alfa) do proteassoma $20 \mathrm{~S}$ e subunidades não-ATPásicas que se ligam a conjugados poliubiquitinados, e uma tampa formada por oito subunidades não-ATPásicas, que atuam no processamento do substrato poliubiquitinado antes da sua degradação (DE DIEGO et al., 2001). O complexo 19S pode associar-se em cada extremidade do barril 20S desempenhando assim, um importante papel no reconhecimento de proteínas ubiquitinadas e outros substratos potenciais do proteassoma, além de permitir a entrada destes na câmara catalítica localizada em 20S (GLICKMAN; CIECHANOVER et al., 2002) (Figura 3 A).

Para que as proteínas sejam degradadas via UPS, elas primeiramente precisam sofrer uma modificação pós-traducional chamada ubiquitinação (HANNA et al., 2007; FRAPPIER; VERRIJZER, 2011). Em tal evento, um resíduo específico de lisina, na superfície do substrato proteico, é covalentemente ligado à região C-terminal de uma molécula de ubiquitina (SALOMONS et al., 2010). Os substratos podem ser modificados por monoubiquitinação, que consiste na ligação de apenas uma molécula de ubiquitina em um ou mais de seus resíduos de lisina, ou poliubiquitinados. Na poliubiquitinação, cadeias de ubiquitinas são montadas no substrato via formação de uma ligação isopeptídica entre um resíduo de lisina de uma ubiquitina anterior com o resíduo de glicina $76\left(\mathrm{Gly}^{76}\right)$ da próxima ubiquitina. A poliubiquitinação tem sido descrita por promover uma degradação rápida das proteínas marcadas via proteassoma $26 \mathrm{~S}$, enquanto que monoubiquitinação têm sido relacionada à resposta ao estresse celular, remodelação da cromatina e na regulação da estabilidade de p53 (TERRELL et al., 1998; BROOKS; GU, 2006). A ligação das moléculas de ubiquitina ao substrato, e a ligação dessas moléculas entre si, são eventos dependentes de energia (ATP), e ocorrem por intermédio de passos enzimáticos altamente regulados (PICKART, 2001), envolvendo três classes de enzimas: enzimas ativadoras de ubiquitina (E1), enzimas conjugadoras de ubiquitina (E2) e enzimas ubiquitina ligases (E3) (HERSHKO; CIECHANOVER, 1998). As enzimas ubiquitina ligases (E3) são cruciais para o processo de 
ubiquitinação, apresentando um duplo papel, seja como ativadoras das enzimas conjugadoras de ubiquitina ou como aceptoras das moléculas de ubiquitina, promovendo assim sua transferência para os substratos proteicos marcados para degradação via proteassoma (WOLF, 2004) (Figura 3 B).

A

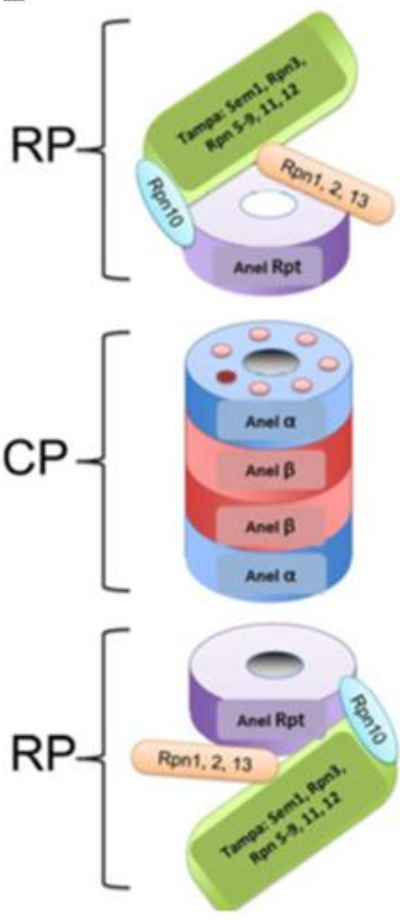

B
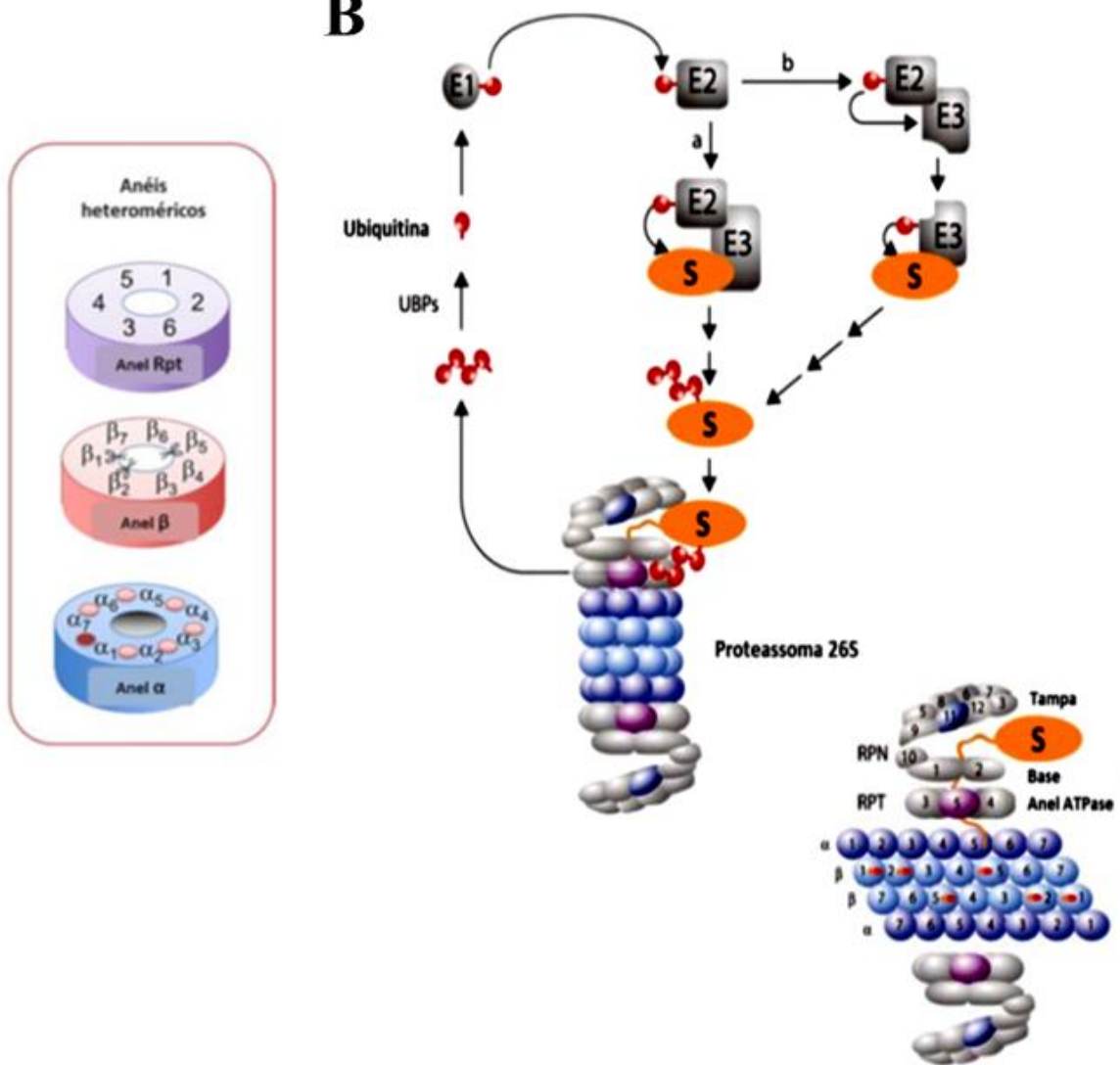

Figura 3. Sistema Ubiquitina-Proteassoma e via de ubiquitinação de substratos para degradação proteassomal. (A) Estrutura do proteassoma $26 \mathrm{~S}$ (RP) partícula regulatória e (CP) partícula central (B) Via de ubiquitinação: E1: enzimas ativadoras de ubiquitina, E2: enzimas conjugadoras de ubiquitina e E3: ubiquitina ligases. Adaptado de (A) BEDFORD (2010) e (B) KOSTOVA; WOLF 2003.

Além da partícula 19S, o núcleo 20S do proteassoma pode estar associado com outros elementos ativadores (DEMARTINO; SLAUGHTER, 1999). Um destes complexos regulatórios, o complexo PA200, é um ativador do Proteassoma 20S envolvido no reparo do DNA (USTRELL et al., 2002). Além destes, outro importante ativador do proteassoma é o complexo PA28, o qual é formado por subunidades $\alpha, \beta$ ou $\gamma$, sendo responsável pela degradação de peptídeos não poliubiquitinados de uma maneira ATP-independente (RECHSTEINER; HILL, 2005). 


\subsection{Importância das enzimas deubiquitinadoras}

A funcionalidade do proteassoma é devido à interação entre diferentes maquinarias enzimáticas. Como visto acima, as enzimas ligadoras de ubiquitina (E3) desempenham um papel chave no sistema ubiquitina-proteassoma. Além desta maquinaria ligadora de ubiquitina, as enzimas deubiquitinadoras (DBUS) são extremamente importantes, pois desempenham diversas funções na regulação da via de ubiquitina proteassoma (WILKINSON, 1997).

Primeiramente, as DUBS promovem o recrutamento de monômeros de ubiquitina, a partir de cadeias lineares de poliubiquitina ou pela clivagem de ubiquitina oriunda de próproteínas de ubiquitinas, as quais são expressas acopladas a duas proteínas ribossomais. Além disso, promovem o recrutamento das moléculas de ubiquitina que acidentalmente tenham sido ligadas a intermediários envolvidos na via de ubiquitinação, e por fim, controlam de forma negativa a degradação de proteínas via proteassoma, uma vez que podem sequestrar a ubiquitina covalentemente ligada a substratos proteicos alvos para degradação via proteassoma (KOMANDER et al., 2009; REYES-TURCU et al., 2009). Desta forma, estas enzimas são importantes para manter o pool celular de ubiquitina (AMERIK; HOCHSTRASSER, 2004).

As proteínas deubiquitinadoras pertencem à superfamília das proteases, sendo em sua maioria cisteíno-proteases, sendo organizadas em quatro subclasses: ubiquitin-specific protease (USP), ubiquitin C-terminal hydrolase (UCH), Otubain protease (OTU) e MachadoJoseph disease protease (MJD). Algumas DUBS são metalo-proteases e possuem um domínio ubiquitina-protease chamado JAMM (JAB1/MPN/Mov34). Estas subclasses de enzimas diferem quanto aos resíduos de aminoácidos presentes em seus sítios catalíticos (NIJMAN et al., 2005).

Várias proteínas acessórias têm sido recentemente descritas associadas transitoriamente com o núcleo do proteassoma, regulando assim sua atividade e a taxa de degradação proteica (PICKETT, 2007). Uma destas proteínas acessórias inclui a enzima deubiquitinadora Ubp6, proteína associada à base do complexo 19S (HANNA et al., 2006), a qual recruta moléculas de ubiquitina a partir de substratos proteicos (FINLEY, 2009). Leggett e colaboradores (2002) descreveram algumas proteínas que apresentam grande afinidade por proteassoma purificado em Saccharomyces cerevisiae, sendo Ubp6 caracterizada como uma proteína encontrada em grande quantidade associada ao proteassoma. Este mesmo autor demonstrou que Ubp6 é ativada pela ligação ao proteassoma, fazendo com que desta forma, Ubp6 funcione obrigatoriamente como um componente do proteassoma. 
Outra importante atividade de deubiquitinação associada ao proteassoma é a subunidade Rpn11, a qual é um componente estrutural presente na tampa do complexo regulatório 19S (CROSAS et al., 2006). Esta enzima é uma metalo-protease responsável pela remoção de cadeias de ubiquitina em blocos conjugados, aparentemente pela clivagem na região terminal próximo a ligação substrato-ubiquitina (VERMA et al., 2002). As atividades deubiquitinadoras de Rpn11 e Ubp6 são contrárias, sendo que a clivagem por Rpn11 é associada à degradação do substrato (YAO; COHEN, 2002), enquanto que a atividade de Ubp6 pode inibir a degradação (HANNA et al, 2006).

Nas células, o proteassoma pode estar associado com atividades deubiquitinadoras, conforme descrito acima, bem como com atividades ubiquitina ligases (CROSAS et al., 2006). As tampas do complexo $19 \mathrm{~S}$ podem associar-se com a proteína ubiquitina ligase Hul5 (LEGGETT et al., 2002), a qual tem sido descrita, em S. cerevisiae, como sendo a principal proteína associada ao proteassoma responsável por estender as cadeias de multiubiquitina nos substratos proteicos e, portanto, promover a ativação da dos substratos (ZHANG, 2009).

O processo de marcação de substratos para degradação via proteassoma é geralmente entendido como sendo dependente de longas cadeias de multiubiquitina que são formadas nos substratos. No entanto, vários trabalhos têm demonstrado a existência de uma via alternativa pela qual alguns substratos podem ser direcionados para degradação via proteassoma por meio de curtas cadeias de ubiquitina. Deste modo, a multiubiquitinação requer atividades enzimáticas adicionais de um fator de elongação de ubiquitina corrente, ou E4 (KOEGL et al., 1999; ZHANG, 2009).

Tem sido demonstrado que enzimas ubiquitinas ligases e enzimas deubiquitinadoras, muitas das vezes funcionam em conjunto. Hul5, juntamente com Ubp6 alteram a dinâmica das cadeias de ubiquitina que já se encontram associadas ao proteasoma (ZHANG, 2009) (Figura 4). Estas enzimas podem interagir bioquímica e geneticamente - mutações em um destes componentes são compensadas pelo outro, sugerindo que Hul5 e Ubp6 possuem atividades opostas, ou seja, Ubp6 desmonta cadeias de ubiquitina estendidas por Hul5, enquanto Hul5 pode elongar cadeias previamente encurtadas por Ubp6. 


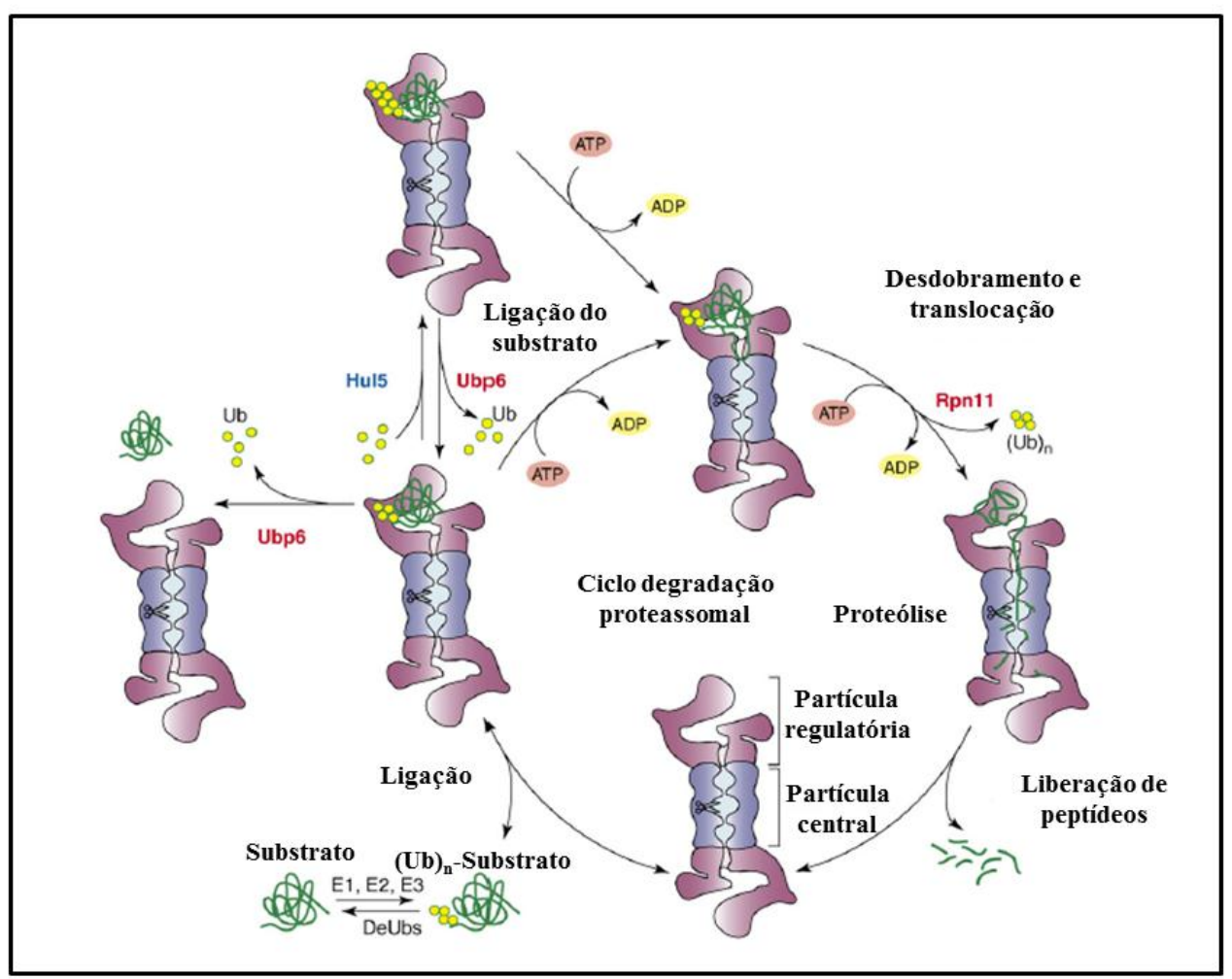

Figura 4. Ciclo de degradação proteassomal e as atividades de Hul5 e Ubp6. Os substratos são poliubiquitinados através das enzimas E1, E2 e E3 (canto inferior esquerdo). Posteriormente, o substrato se liga ao proteassoma sendo em seguida, desdobrado e degradado de maneira ATP-dependente, ou liberado com concomitante remoção da cadeia de poliubiquitina por Rpn11. A liberação pode ser acelerada pela ação da enzima Ubp6, a qual diminui a afinidade do substrato. O alongamento da cadeia de ubiquitina pela ação de Hul5 aumenta a afinidade do substrato pelo proteassoma, diminuindo a taxa de liberação e assim promovendo o aumento da taxa de degradação. O balanço entre as atividades de Hul5 e Ubp6 pode afetar o equilíbrio entre ligação e liberação por modificar o comprimento da cadeia de poliubiquitina e assim afetar a taxa de liberação. Adaptado de KRAUT et al. (2007).

Sendo assim, este mecanismo de atuação mútua das duas atividades enzimáticas pode contribuir como um mecanismo adicional para regulação da degradação proteica, uma vez que Hul5 facilita a degradação de proteínas por aumentar o tempo que os substratos permanecem no proteassoma, enquanto Ubp6 protege o proteassoma de sobrecarga por causar liberação do substrato (KRAUT et al., 2007). A abundância celular de Ubp6 é sensivel aos níveis celulares de ubiquitina, logo em uma condição onde ocorre depleção de ubiquitina na célula, haverá um aumento na expressão de Ubp6 a qual é normalizada quando os níveis de ubiquitina são restaurados. A up-regulação de Ubp6 resulta em uma grande carga de proteassomas com Ubp6, presumivelmente resultando em um aumento na eficiência de reciclar ubiquitina pelo proteassoma (HANNA et al., 2007). 


\subsection{Proteoassoma e o desenvolvimento de parasitos}

Como relatado acima, a via de degradação intracelular de proteínas ubiquitinaproteassoma é uma importante nanomáquina proteolítica descrita em uma grande diversidade de organismos, dentre eles parasitos, nos quais desempenham importantes papéis no seu desenvolvimento (GANTT et al., 1998; ROBERTSON, 1999; SHAW et al., 2000). Nosso grupo de trabalho demonstrou, em S. mansoni, a existência um sistema proteolítico dependente de ubiquitina, o qual é de extrema importância para o desenvolvimento do parasito (GUERRA-SÁ et al., 2005). Neste trabalho, foi demonstrado que a inibição da atividade catalítica do proteassoma 20 utilizando o inibidor MG-132 em vermes adultos de $S$. mansoni, reduz o número de esquistossômulos na fase pulmonar, o número de vermes adultos e consequentemente diminui a ovoposição em camundongos infectados. Estes dados demonstram que o sistema ubiquitina-proteassoma apresenta um importante papel no desenvolvimento de S. mansoni, e que inibidores do proteassoma podem ser utilizados como importantes ferramentas no estudo dos mecanismos moleculares utilizados pelo parasito durante seu desenvolvimento no hospedeiro vertebrado.

Guerra-Sá (2000) demonstrou pela primeira vez a expressão do gene SmUbi (Schistosoma mansoni poliubiquitina) em todas as formas de desenvolvimento do parasito. Posteriormente, esta expressão foi confirmada pela presença de conjugados ubiquitinados em extratos proteicos totais de cercárias, esquistossômulos e vermes adultos, sendo o nível destes conjugados poliubiquitinados relativamente maior nas fases larvais quando comparado com a fase adulta, sugerindo que via de degradação dependente de ubiquitina e proteassoma exercem papel importante nos processos de remodelagem de S. mansoni (CASTRO-BORGES, 2005).

Soares (2011) demonstrou recentemente que em S. mansoni o complexo PA28 (ativador do proteassoma) é caracterizado com sendo composto por subunidade do tipo $\gamma$. Análises de expressão de PA28y durante os diferentes estágios de vida deste parasito mostraram que este ativador é diferencialmente expresso e pode potencialmente desempenhar um importante papel no crescimento e desenvolvimento deste parasito. Além de ativadores, o proteassoma $20 \mathrm{~S}$ pode transitoriamente associar-se à proteína inibitória PI31. BotelhoMachado e colaboradores (2010) demonstraram que a proteína PI31 (inibidor competitivo do PA28) inibe a degradação de peptídeos fluorogênicos pelo proteassoma. Neste trabalho, a proteína recombinante $S m$ PI31 inibiu em até 64\% a atividade do proteassoma. Morais (2009) realizou a caracterização molecular e funcional da subunidade Rpn10 do proteassoma do parasita S. mansoni durante seu ciclo evolutivo e também avaliou o seu potencial como alvo de vacina contra a esquistossomose. Os resultados deste trabalho, demonstraram que o gene 
SmRpn10 é diferencialmente expresso nas fases do ciclo de vida do parasito e a imunização com a SmRpn10 recombinante induziu $20 \%$ de proteção contra a infecção experimental com S. mansoni.

Numerosas drogas relacionadas à inibição do proteassoma têm sido descritas na literatura e muitas delas interferem diretamente com a atividade proteolítica da partícula central 20S (DICK, 1997; ADAMS et al., 1999; MENG et al., 1999a; MENG et al., 1999b). Estes inibidores podem se ligar de forma reversível ou irreversível aos sítios ativos no complexo 20S, podendo acarretar diferentes taxas de inibição ao proteassoma $26 \mathrm{~S}$.

Nosso grupo de pesquisa tem estudado os efeitos in vitro de diversos compostos sob o parasito S. mansoni. O composto fenólico proveniente da planta Curcuma longa (Curcumina), tem sido descrito com uma droga que pode ter ação sobre o proteassoma 20S (HATCHER et al., 2008; MAGALHAES et al., 2009). Esta droga é conhecida por exibir várias atividades biológicas, incluindo atividades anti-inflamatória, antioxidante, antiviral, anti-infecção e anticarcionogênica (TODA et al., 1985; RUBY et al., 1995; ARAUJO et al., 1999; HAN et al., 2002; MAHESHWARI et al., 2006, SHIH et al., 2007). Muitos autores tem descrito também a atividade anti-protozoal desta substância em Leishmania donovani (DAS et al., 2008), Leishmania major (KOIDE et al., 2002), Giardia lamblia (PÉREZ-ARRIAGA et al., 2006) e Trypanosoma brucei (NOSE et al., 1998; NKEMGU-NJINKENG et al., 2002). Em adição, El-Ansary e colaboradores (2007), El-Banhawey e colaboradores (2007) e Allam (2009) demonstraram o efeito do extrato de $C$. longa em camundongos infectados com $S$. mansoni. Recentemente, Cheng e colaboradores (2012) mostraram que Curcumina possui atividade esquistossomicida contra a fase adulta sem sensibilidade diferencial entre machos e fêmeas e também diminui a atividade motora de vermes de $S$. japonicum.

Magalhaes e colaboradores (2009) demonstraram que a Curcumina causa a separação dos casais de vermes adultos de $S$. mansoni, infertilidade dos ovos, diminuição da ovoposição e da viabilidade dos parasitos, levando-os a morte. Morais (2012) mostrou, através de microarray, que o perfil de expressão gênica de vermes adultos de $S$. mansoni após tratamento com $15 \mu \mathrm{M}$ de Curcumina por $72 \mathrm{~h}$ é significativamente alterado. Neste trabalho, foi relatada uma diferença na expressão de 4185 genes (reprimidos e induzidos) após o tratamento com Curcumina, dentre os quais estão: Notch (Smp_105360), Proteína repressora transcricional yy (Smp_023990), Anexina (Smp_074150), Receptor TGF-beta (Smp_049760), Proteína 1 de resistência a multidrogas (Smp_171740), Quinase semelhante a Polo (Smp_009600), Proteína quinase Tousled (Smp_141580) e Precursor da isoforma A da caspase 8 (Smp_141270). Recentemente, Morais e colaboradores (2013) sugerem que efeitos 
in vitro de Curcumina descritos por Magalhaes e colaboradores (2009) estão relacionados com a alteração na expressão de genes relacionados às vias Notch e TGF- $\beta$ observada em seu trabalho.

Outra importante droga cujo efeito em S. mansoni tem sido caracterizado por nosso grupo é a substância IBMX, o qual é um inibidor competitivo e não seletivo da enzima fosfodiesterase (ESSAYAN, 2001), que interfere nas vias de sinalização por aumentar os níveis de AMPc intracelular, ativar a proteína kinase A (PKA), inibir tanto o TNF-alfa (DEREE, et al, 2008; MARQUES et al, 1999) como a síntese de leucotrieno (PETERSGOLDEN et al, 2005). IBMX também é conhecido como antagonista do receptor de adenosina não seletivo (DALY et al, 1987). Moreira (2008) demonstrou que este composto possivelmente inibi a atividade do proteassoma sendo esta inibição avaliada pelo aumento de proteínas ubiquitinadas nos parasitos. A redução da atividade do proteassoma, foi relacionada com uma possível desmontagem do complexo proteolítico, indiretamente mostrada pelo aumento da expressão da proteína de maturação do proteassoma (SmPOMP), a qual é conhecida como um marcador molecular indicando montagem de novas populações de proteassoma, bem como pela diminuição nos níveis das subunidades $\alpha$ do proteassoma. Além disso, este composto promoveu a redução no número de ovos durante o cultivo in vitro de casais de S. mansoni, sem promover a separação de casais e alteração na viabilidade dos parasitos.

Além dos efeitos de Curcumina em vermes adultos de S. mansoni, Morais (2012) também descreveu a alteração no perfil de expressão gênica após o tratamento de vermes adultos com o composto MG132. A categorização dos genes diferencialmente expressos mostrou que $26 \%$ e $22 \%$ dos produtos gênicos induzidos estão relacionados a processos celulares e metabólicos, respectivamente. Além disso, muitos genes com a expressão modificada após o tratamento com MG132 estão relacionados ao sistema ubiquitinaproteassoma, como exemplo, a proteína de maturação do proteassoma (POMP Smp_074160), Subunidade regulatória não ATPásica do proteassoma 26S (Smp_052870); Subunidade 4 ativadora do proteassoma 26S (Smp_126760); Subunidade S3 regulatória do proteassoma 26S (Smp_085310.2). Desta forma, o estudo da regulação da expressão de genes relacionados ao proteoassoma de S. mansoni sobre o efeito de diferentes compostos com atividade sobre este parasito, pode contribuir para melhor entendimento da sua biologia bem como os mecanismos utilizados para resposta ao estresse. 


\subsection{Estresse celular versus Sistema Ubiquitina-Proteassoma}

As células são expostas a muitas situações de estresse tais como calor, estresse oxidativo, inflamação, irradiação, ou outros componentes tóxicos. Estes agentes de estresse provocam danos às biomoléculas celulares, principalmente ao DNA, proteínas e lipídeos (KULTZ, 2005; KASTLE; GRUNE, 2012). Desta forma, um pequeno aumento na temperatura celular pode provocar o desdobramento de protéinas, agregação inespecífica, além de um desequilíbrio na homeostase de proteínas. Por esta razão, as células devem apresentar mecanismos de respostas aos diferentes tipos de estímulos, e como resultado das variações no ambiente celular, ocorre um ordenado controle na expressão gênica permitindo a expressão de genes relacionados aos mecanismos de proteção da célula (RICHTER et al., 2010). Este grupo de genes responsivos ao estresse podem ser divididos em: genes da família das proteínas de resposta a choque térmico (Hsps), genes relacionados ao sistema proteolítico, enzimas de reparo de ácidos nucléicos, enzimas metabólicas, proteínas regulatórias e proteínas relacionadas à estabilização do citoesqueleto, detoxificação e estabilidade da membrana (JANTSCHISTSCH; TRAUTINGER, 2003; MALMENDAL et al., 2006; AL REFAII; ALIX, 2009; WELKER et al., 2010).

O estresse térmico promove alterações drásticas na organização interna da célula. Além do desdobramento de proteínas individuais, muitos outros danos são observados, como por exemplo, o aumento na temperatura pode acarretar a formação de inclusões, aumento no número de filamentos ou a reorganização dos filamentos no citoesqueleto (TOIVOLA et al., 2010). Com a reestruturação ou até mesmo colapso nas redes de filamentos do citoesqueleto, as organelas são realocadas intracelularmente e desta forma é observado um colapso no transporte intracelular. Além disso, é possível observar uma fragmentação do sistema Complexo de Golgi-Retículo endoplasmático bem como uma diminuição no número de mitocôndria e lisossomos (WELCH; SUHAN, 1985). No núcleo, diversos processos como splicing, replicação e transcrição são alterados, além disso, ocorre a agregação de proteínas ribossomais (BOULON et al., 2010).

O sistema de defesa composto pelas chaperonas moleculares e o sistema proteassomal desempenham um papel crucial na manutenção da homeostase das proteínas durante o estresse celular. As chaperonas moleculares são um amplo grupo de proteínas citosólicas da família das Hsps (heat shock proteins) que necessitam de co-chaperonas para a sua funcionalidade. Estas proteínas são necessárias para o refolding (restruturação) e estabilização das proteínas no citoplasma, evitando desta forma a agregação proteica após situações de estresse (MAYER, 2010; TOIVOLA et al., 2010). Existe uma relação intrínseca entre as 
chaperonas moleculares e o sistema proteassomal de degradação proteica na qual uma proteína desdobrada é inicialmente estabilizada pelo sistema de chaperonas e co-chaperonas e caso esta não seja reestruturada, as chaperonas então facilitam o processo de ubiquitinação destas proteínas e sua degradação pelo proteassoma. Desta forma, podemos perceber que estes dois sistemas são estritamente relacionados e regulados (KASTLE; GRUNE, 2012).

Além das respostas em relação ao estresse térmico, o sistema proteassomal em conjunto com as chaperonas moleculares desempenham um papel importante na resposta a outros tipos de estresse, como por exemplo, o estresse oxidativo. Neste tipo de estresse existe um desequilíbrio de espécies reativas de oxigênio (ROS) e os mecanismos de defesa antioxidante, o que acarreta em mudanças na homeostase celular (Figura 5). Os organismos possuem respostas adaptativas para o estresse oxidativo os quais permitem a ativação ou silenciamento de genes que codificam para enzimas de defesa, fatores de transcrição e proteínas estruturais (DALTON et al., 1999). Em adição, o sistema de defesa formado pelas chaperonas moleculares e o sistema proteassomal possuem o aparato necessário para defender a célula neste tipo de estresse (KALMAR; GREENSMITH, 2009; JAKOB et al., 1999).

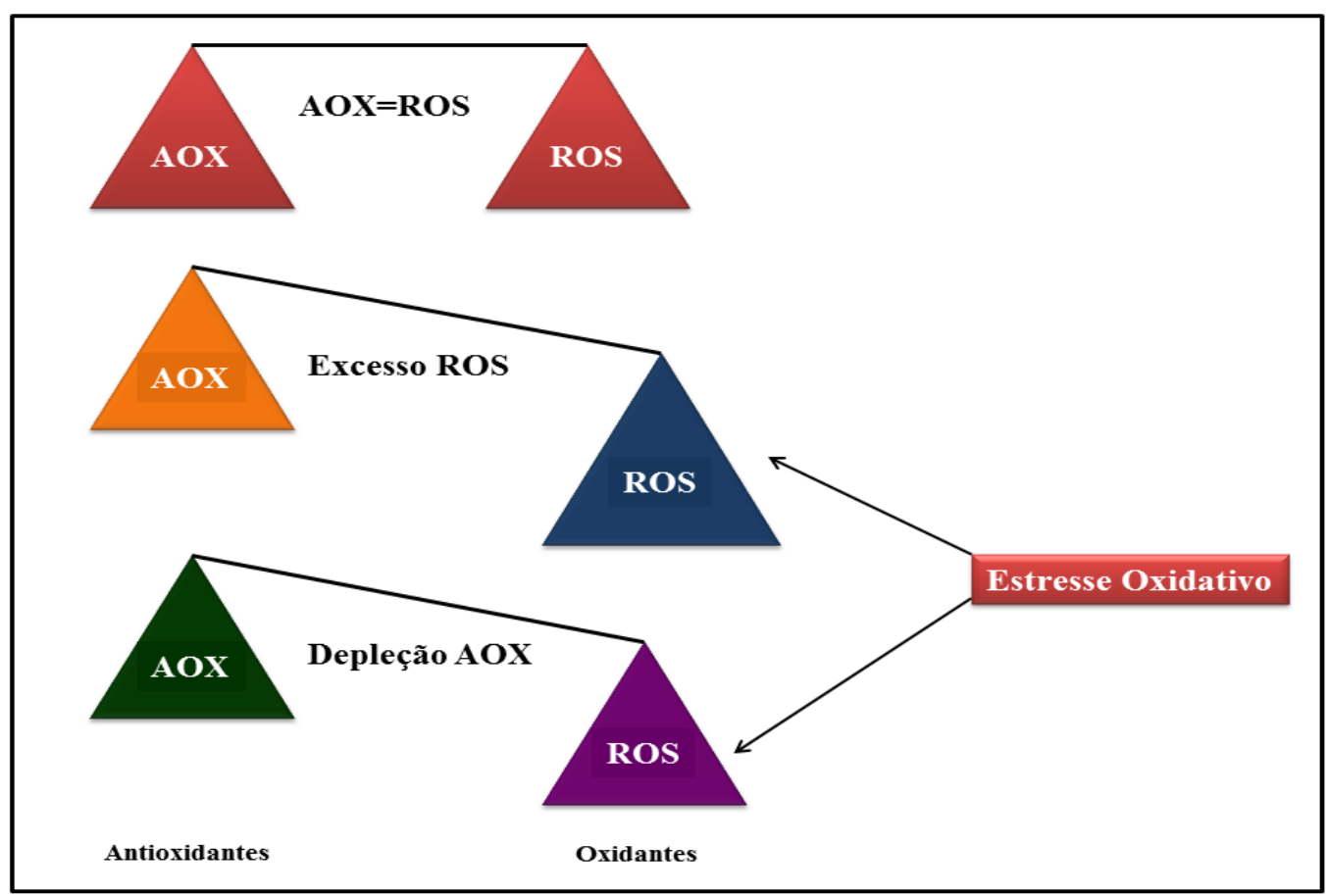

Figura 5. Estresse oxidativo: balanço entre espécies reativas de oxigênio (ROS) e antioxidantes (AOX). Em condições normais, as células são capazes de promover um equilíbrio na produção de oxidantes e antioxidantes (como por exemplo, catalase e superóxido dismutase), resultando em um balaço redox equilibrado. Estresse oxidativo promove um desbalanço entre estas duas situações, e ocorre quando as células são sujeitas a excesso de ROS, ou como resultado de depleção das defesas antioxidantes. Adaptado de SCANDALIOS (2002). 
Dentre as principais mudanças que acontecem durante o estresse oxidativo podemos citar a carbonilação de proteínas ou rompimento de pontes dissulfeto, modificações que dificultam a manutenção da conformação nativa das proteínas (KASTLE; GRUNE, 2011). No estresse oxidativo, as chaperonas moleculares ligam-se as proteínas modificadas com o objetivo de redobrar ou estabilizar a proteína para degradação proteassomal (Figura 6). Segundo Grune e colaboradores (2011) existe uma conexão direta entre estes dois sistemas de defesa da célula, especialmente na resposta inicial ao estresse oxidativo. De acordo com estes autores, neste tipo de resposta inicial ao estresse oxidativo, existe uma diminuição na população de proteassomas $26 \mathrm{~S}$, enquanto que a quantidade de proteassoma $20 \mathrm{~S}$ permanece inalterada. Nesta situação, a partícula regulatória 19S perde contato com o núcleo 20S, mas, permanece intacta e passa por um processo de remontagem para proteassoma 26S após 3h de exposição a $\mathrm{H}_{2} \mathrm{O}_{2}$. Além disso, foi sugerido que a estabilização da partícula regulatória 19S é mediada pela chaperona HSP70, uma vez que a sua inibição por RNAi ou inibidor específico impediu a remontagem de proteassomas 26S após estresse oxidativo.

A degradação de proteínas oxidadas é realizada principalmente pela partícula $20 \mathrm{~S}$ (GRUNE et al., 2011) e existem evidências de que este processo seja independente de ubiquitinação (SHRINGARPURE et al., 2003). Entretanto, Yamanaka e colaborares (2003) sugerem o envolvimento de vias de ubiquitinação na degradação de proteínas oxidadas. Além disso, tem sido relatado que componentes do sistema ubiquitina-proteassoma são altamente sensíveis ao estresse oxidativo, o que implica na inibição de ubiquitinação de proteínas ou no desacoplamento do complexo 26S (WANG et al., 2010; KRIEGENBURG et al., 2011). Estudos recentes demonstram que as proteínas HSP90/HSP70 são utilizadas pelo sistema ubiquitina-proteassoma para o reconhecimento de proteínas anormais (MURATA et al., 2001; MARQUES et al., 2006). 


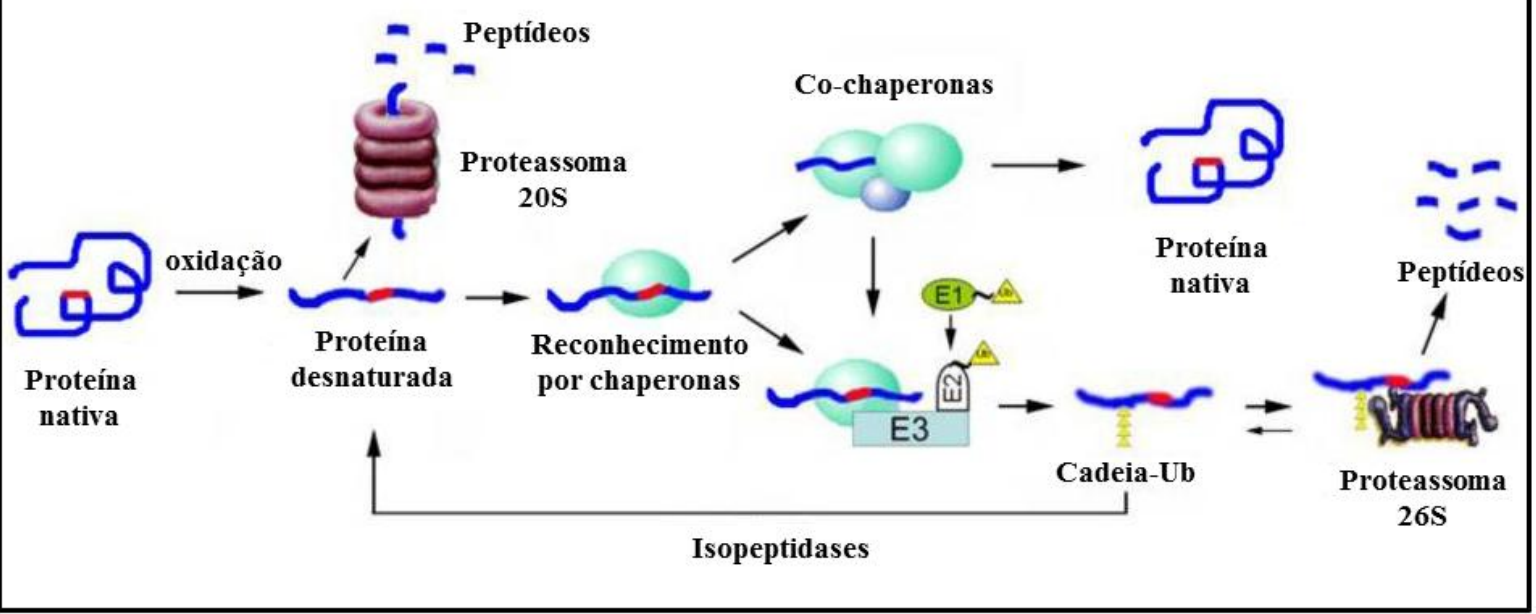

Figura 6. Reconhecimento de proteínas oxidadas para degradação pelo sistema ubiquitina-proteassoma (UPP). As proteínas apresentam sinais intrínsecos para interação com chaperonas ou sistema de ubiquitinação (vermelho). Estes sinais encontram-se escondidos nas proteínas nativas e sob condições de estresse, como oxidação, as proteínas são desdobradas e ocorre exposição dos sinais de reconhecimento, como regiões hidrofóbicas. Muitas proteínas desdobradas são reconhecidas e degradadas diretamente pelo proteassoma $20 \mathrm{~S}$ enquanto outras são reconhecidas por chaperonas moleculares. As chaperonas moleculares podem com a ajuda de outras chaperonas ou cofatores redobrar as proteínas desnaturadas de maneira ATP dependente. Caso as proteínas desnaturadas não forem rapidamente redobradas, o substrato ligado as chaperonas são ubiquitinados (triângulos amarelos) por chaperonas que interagem com enzimas E3 ligases, sendo então marcadas para degradação via proteassoma 26S. Pela ação de isopeptidases (por exemplo, DBUs), as proteínas ubiquitinadas podem ser deubiquitinadas e as proteínas desnaturadas tem uma segunda chance de ser redobradas por chaperonas moleculares. Esta relação paralela e competitiva entre UPP e chaperonas moleculares assegura a eficiência do sistema de controle de proteínas que dirige a degradação de proteínas anormais. Adaptado de SHANG; TAYLOR (2011).

\subsection{Schistosoma mansoni: visão geral dos mecanismos de resposta ao estresse}

O parasito $S$. mansoni é exposto para espécies reativas de oxigênio durante o ciclo de vida, seja através de seu próprio processo fisiológico (respiração) ou como resultado da resposta imune do hospedeiro. Desta forma, este organismo deve apresentar mecanismos de defesa que permitam o processo de detoxificação. Tem sido relatada na literatura a susceptibilidade estágio-específica na resposta ao estresse oxidativo, uma vez que esquistossômulos são mais sensíveis a este tipo de estresse quando comparado com vermes adultos de S. mansoni. Além disso, foi visto uma alta expressão de proteínas antioxidantes nos estágios mais resistentes para o estresse oxidativo (MKOJI et al., 1988; LOVERDE, 1998).

Além disso, até o momento foram descritos e caracterizados uma série de sistemas enzimáticos com atividade antioxidante. Os mecanismos de defesa já identificados são, duas isoformas de superóxido dismutase (Cu-Zn) (SOD), Peroxirredoxinas (Prxs), glutationa peroxidase (GPX), citocromo c peroxidase, cinco isoformas de glutationa-S-Transferase (GST), glutationa redutase e Tiorredoxina redutase. Curiosamente, a atividade de catalase não tem sido detectada neste parasito (CALLAHAN et al., 1988; MKOJI et al., 1988; NARE et 
al., 1990; HONG et al., 1992a; WILLIAMS et al., 1992; CAMPOS et al., 1995; SAYED et al., 2006). Alger e colaboradores (2002) relatam a evidência de que as atividades de glutationa redutase e tiorredoxina redutase tenham sido substituídas neste parasito pela enzima única tiorredoxina glutationa redutase. Esta enzima multifuncional catalisa a interconversão de ambas as formas reduzidas e oxidadas de glutationa e tiorredoxina, contribuindo assim para a manutenção do balanço redox no parasito. A co-localização de superóxido dismutase e glutationa peroxidase no tegumento e epitélio intestinal bem como seus padrões de expressão no ciclo de $S$. mansoni sugerem que estas enzimas são indispensáveis no sistema de proteção deste parasito (LOVERDE, 1998).

A infecção provocada por $S$. mansoni desencadeia inúmeros mecanismos de defesa do hospedeiro, cuja função primária consiste na manutenção de níveis parasitários compatíveis com a sobrevivência do hospedeiro. Esses mecanismos de defesa, no entanto, raramente garantem completa eliminação do parasito, que possui numerosos processos de evasão das respostas criadas pelos seus hospedeiros. Existem relatos de vermes adultos capazes de sobreviver por mais de 30 anos no organismo sem danos aparentes (VIEIRA et al., 2007).

Recentemente, novas drogas contra o S. mansoni têm sido desenvolvidas, com diferentes mecanismos de ação. A indução de estresse oxidativo em vermes adultos tem sido considerada uma abordagem extremamente interessante para novas estratégias de tratamento. Essa indução pode ocorrer tanto pela inibição do sistema antioxidante de um organismo como pelo aumento da formação de espécies reativas de oxigênio (ROS). Kuntz e colaboradores (2007) e Sayed e colaboradores (2008) demonstraram que a inibição da enzima tiorredoxina glutationa redutase promoveu a morte de esquistossômulos in vitro e parcialmente curou camundongos infectados com S. mansoni. Neste contexto, a inibição de enzimas envolvidas na proteção antioxidante de S. mansoni tem sido considerada uma abordagem interessante para o tratamento medicamentoso da esquistossomose (SIMEONOV et al., 2008).

Conforme relatado acima, a via ubiquitina-proteassoma é importante para o desenvolvimento de diversos organismos, inclusive, S. mansoni. Diante deste fato, e apoiado pela confirmação de uma via proteolítica dependente de ubiquitina neste organismo, bem como o efeito de inibidores do proteassoma em seu desenvolvimento, tornam este sistema um alvo promissor para pesquisa e desenvolvimento de novas drogas para o tratamento da esquistossomose. Desta forma, o entendimento dos mecanismos de defesa, em especial o sistema ubiquitina-proteassoma, empregados por Schistosoma mansoni para responder aos diferentes tipos de estresse, seja o estresse térmico, estresse oxidativo e estresse químico, 
pode gerar informações importantes para o desenvolvimento de novas abordagens para a terapêutica da esquistossomose. 
2. Objetivos 


\section{Objetivos}

\subsection{Objetivo geral}

Compreender os mecanismos de resposta de vermes adultos de Schistosoma mansoni ao estresse oxidativo, estresse térmico e químico bem como analisar a expressão das enzimas SmHul5 e SmUbp6 nos diferentes estágios do ciclo de vida do parasito e em diferentes condições de estresse do proteassoma de Schistosoma mansoni.

\subsection{Objetivos específicos}

\subsubsection{Caracterização dos genes $\mathrm{SmHul5}$ e SmUbp6}

2.2.1.1. Identificar in silico os genes SmHul5 e SmUbp6 em S. mansoni.

2.2.1.2. Sequenciar e analisar em banco de dados os genes em estudo.

2.2.1.3. Analisar a expressão dos genes $S m H u l 5$ e $S m U b p 6$ nas fases do ciclo de vida de S. mansoni.

\subsubsection{Caracterização do estresse oxidativo}

2.2.2.1. Avaliar o efeito do estresse oxidativo em vermes adultos de $S$. mansoni quanto à viabilidade, produção de ovos, alteração no tegumento, motilidade e mortalidade.

2.2.2.2. Analisar a expressão de $S m H u l 5$ e SmUbp6 após o estresse oxidativo.

2.2.2.3. Determinar o conteúdo proteico de proteassoma $20 \mathrm{~S}$ após estresse oxidativo.

2.2.2.4. Obter o perfil de expressão proteica de vermes adultos de $S$. mansoni submetidos a estresse oxidativo.

2.2.2.5. Categorizar as proteínas diferencialmente expressas no estresse oxidativo.

\subsubsection{Caracterização do estresse químico e térmico}

2.2.3.1. Avaliar a produção de ROS intracelular após estresse químico com IBMX, Curcumina e MG132.

2.2.3.2. Analisar a expressão de $S m G P x 1$, SmGPx2, SmSOD, SmTGR, SmHsp70 e SmHsp40 após estresse químico com IBMX, Curcumina e MG132.

2.2.3.3. Analisar a expressão de $S m H u l 5$ e $S m U b p 6$ após estresse químico (IBMX, Curcumina e MG132) e estresse térmico. 
2.2.3.4. Obter o perfil de expressão proteica de vermes adultos de $S$. mansoni submetidos a estresse térmico.

2.2.3.5. Categorizar as proteínas diferencialmente expressas no estresse térmico.

2.2.3.6. Obter o perfil de expressão de $S m P O M P$ em diferentes condições de estresse do proteassoma de S. mansoni. 
3. Material e Métodos 


\section{Material e Métodos}

\subsection{Parasitos}

O ciclo biológico de Schistosoma mansoni (cepa Luís Evangelista - LE) é mantido no Laboratório de Biologia Molecular de Parasitas, do Departamento de Bioquímica e Imunologia da Faculdade de Medicina de Ribeirão Preto (FMRP- USP), utilizando como hospedeiros definitivos camundongos das linhagens Swiss ou Balb/c e como hospedeiros intermediários caramujos da espécie Biomphalaria glabrata. Os ovos do parasito foram recuperados das fezes de camundongos infectados, pelo método de Hoffman (HOFFMAN et al., 1934), e expostos à luz por $1 \mathrm{~h}$ para eclosão dos miracídios. Cerca de 15 a 18 miracídios foram utilizados para infecção de cada caramujo. Após 43 dias de infecção, os caramujos infectados foram expostos à luz para liberação das cercárias. Para infecção dos hospedeiros definitivos, aproximadamente 100 cercárias foram inoculadas em cada camundongo por via subcutânea.

Todos os procedimentos envolvendo o uso destes animais estão de acordo com os Princípios Éticos na Experimentação Animal adotado pelo Colégio Brasileiro de Experimentação Animal (COBEA), sendo aprovado pelo protocolo nº 182/2011.

\subsection{Obtenção de vermes adultos de $S$. mansoni}

Vermes adultos foram obtidos através da perfusão do sistema porta-hepático de camundongos sacrificados após 50-55 dias de infecção, segundo condições previamente descritas por Smithers e Terry (1965). Após a coleta, os parasitos foram cultivados em atmosfera de $5 \% \mathrm{CO}_{2}$ em placas estéreis de 24 poços ou garrafas de cultura estéreis a $37^{\circ} \mathrm{C}$ contendo o meio RPMI 1640 (Invitrogen) suplementado com 25 mM de HEPES (pH 7,5), antibióticos (100 UI/mL de penicilina e $100 \mu \mathrm{g} / \mathrm{mL}$ de estreptomicina - Invitrogen), $10 \%$ de soro fetal bovino (Invitrogen). Após 24 horas de cultivo in vitro os vermes foram utilizados nos experimentos de estresse sendo em seguida armazenados a $-70^{\circ} \mathrm{C}$ até o momento do uso.

\subsection{Obtenção de ovos de $S$. mansoni}

Para a obtenção dos ovos aproximadamente 10 fígados de camundongos após 50-55 dias de infecção foram coletados durante perfusão hepática e homogeneizados em $200 \mathrm{~mL}$ de 
tampão fosfato $\left(0,06 \mathrm{M}\right.$ de $\mathrm{Na}_{2} \mathrm{HPO}_{4}, 0,0033 \mathrm{M}$ de $\left.\mathrm{KH}_{2} \mathrm{PO}_{4}, \mathrm{pH} 8,3\right)$, contendo $20 \mathrm{mg}$ de tripsina (Invitrogen). $\mathrm{O}$ homogeneizado foi mantido sob agitação a $37^{\circ} \mathrm{C}$ durante $3 \mathrm{~h} \mathrm{e}$, posteriormente, os ovos foram recuperados por dupla peneiração em malhas de 300 e $180 \mu \mathrm{m}$ em solução salina isotônica ( $\mathrm{NaCl}$ 0,9\%) (CASTRO-BORGES, 2005), e armazenados a $70^{\circ} \mathrm{C}$.

\subsection{Obtenção de cercárias e transformação mecânica de cercárias em esquistossômulos}

A transformação mecânica de cercárias em esquistossômulos foi realizada segundo o método descrito por Ramalho-Pinto e colaboradores (1974). Para isto, caramujos infectados foram expostos à iluminação artificial em banho de água a $26^{\circ} \mathrm{C}$ por $1 \mathrm{~h}$ para induzir a liberação das cercárias. Em seguida, aproximadamente 120000 cercárias foram transferidas para um béquer de vidro de $100 \mathrm{~mL}$ e incubadas em gelo por duas horas para sedimentação. Após este período, o sobrenadante foi aspirado com o auxílio de pipeta Pasteur e, as cercárias presentes no fundo do tubo foram transferidas para um tubo de poliestireno (tubo Falcon) de $15 \mathrm{~mL}$. Em seguida as cercárias foram ressuspendidas em $10 \mathrm{~mL}$ de água declorada autoclavada e deixadas em gelo por 10 minutos para sedimentação, sendo o sobrenadante posteriormente descartado. Este processo de lavagem foi repetido por três vezes. Posteriormente, a água foi retirada e foram adicionados $6 \mathrm{~mL}$ de meio RPMI 1640 (Invitrogen). Para transformação mecânica, as cercárias foram vigorosamente agitadas em vórtex (Phoenix AP-56) sob velocidade máxima durante 90 segundos para a indução do rompimento das cercárias em corpos cercarianos e caudas.

Em condições estéreis, os corpos e caudas cercarianas foram ressuspendidos e transferidos para um frasco de cultura contendo $30 \mathrm{~mL}$ de meio RPMI 1640 (Invitrogen) suplementado com $100 \mathrm{UI} / \mathrm{mL}$ de penicilina e $100 \mu \mathrm{g} / \mathrm{mL}$ de estreptomicina (Invitrogen) e, em seguida incubados em estufa umidificada contendo $5 \%$ de $\mathrm{CO}_{2}$, a $37^{\circ} \mathrm{C}$, por um período de 4 horas. Decorrido este intervalo de incubação, aproximadamente $28 \mathrm{~mL}$ de sobrenadante descartado e os $2 \mathrm{~mL}$ restantes foram distribuídos em tubos eppendorf ( $1 \mathrm{~mL} / \mathrm{tubo})$. Para remoção das caudas, $1 \mathrm{~mL}$ de meio RPMI 1640 (Invitrogen) foi adicionado em cada tubo contendo os corpos cercarianos e as caudas, procedendo-se desta forma cinco lavagens com meio RPMI com um intervalo de 4 minutos entre cada lavagem (sedimentação dos corpos cercarianos e remoção das caudas presentes no sobrenadante). As lavagens foram acompanhadas em microscópio de luz invertida (Leitz, Diavert). 
Em seguida, o material foi transferido para garrafas de cultura estéril de $50 \mathrm{~mL}$ e o volume completado para $30 \mathrm{~mL}$ com meio RPMI 1640 (Invitrogen) suplementado com $20 \mu \mathrm{M}$ de HEPES, pH 7,4, $100 \mathrm{UI} / \mathrm{mL}$ de penicilina e $100 \mu \mathrm{g} / \mathrm{mL}$ de estreptomicina e $10 \%$ de soro fetal bovino (Invitrogen). A cultura foi mantida em atmosfera umidificada contendo 5\% de $\mathrm{CO}_{2}$ a $37^{\circ} \mathrm{C}$ (HARROP; WILSON, 1993), durante 0, 2, 4, 6, 8 e 18,5 horas. Após o período de incubação, cerca de $28 \mathrm{~mL}$ de sobrenadante foi aspirado e descartado, sendo os $2 \mathrm{~mL}$ restantes distribuídos em tubos de $2 \mathrm{~mL}$ e imediatamente recuperados por centrifugação $1000 \times \mathrm{g}$, a $4^{\circ} \mathrm{C}$, durante 3 minutos (Centrífuga 5417R-Eppendorf), e mantidos a $-70^{\circ} \mathrm{C}$ até o momento do uso. As cercárias não utilizadas no processo de obtenção dos esquistossômulos foram coletadas para extração de RNA, sendo da mesma foram mantidas a $-70^{\circ} \mathrm{C}$.

\subsection{Obtenção de miracídios e esporocistos de $S$. mansoni}

As fases evolutivas de miracídio e esporocisto foram obtidas de acordo com o protocolo descrito por Yoshino e Laursen (1995) e gentilmente cedidas pela Dr. Claúdia Sossai Soares.

\subsection{Ensaios in vitro de estresse do proteassoma de $S$. mansoni}

\subsubsection{Estresse químico}

Para os testes de estresse químico in vitro com $S$. mansoni as drogas utilizadas foram diluídas em DMSO (Mallinckrodt Chemicals) e usadas nas concentrações finais de 80 e 200 $\mu \mathrm{M}$ para IBMX (MOREIRA, 2008) e 5 e $10 \mu \mathrm{M}$ para Curcumina (MAGALHAES, 2009). Após perfusão, os vermes adultos foram mantidos a $37^{\circ} \mathrm{C}$ em atmosfera de $5 \% \mathrm{CO}_{2}$ por $24 \mathrm{~h}$ para aclimatação. Aproximadamente 20 casais de vermes adultos foram cultivados em garrafas de cultura estéreis, contendo $10 \mathrm{~mL}$ de meio RPMI suplementado com $20 \mu \mathrm{M}$ de HEPES (pH 7,5), antibióticos (100 UI/mL de penicilina e $100 \mu \mathrm{g} / \mathrm{mL}$ de estreptomicina) e $10 \%$ de soro fetal bovino (Invitrogen). Os tempos de tratamento foram de 24 horas, 48 horas e 72 horas para IBMX e 24 horas para Curcumina. Como controles negativos foram utilizados vermes adultos mantidos em meio RPMI e RPMI + DMSO. Como controle positivo foram utilizados vermes adultos tratados com $50 \mu \mathrm{M}$ de MG132 (GUERRA-SÁ, 2000) por 24 horas. Após os tratamentos, os vermes foram retirados do meio, lavados com meio RPMI e 
armazenados a $-70^{\circ} \mathrm{C}$ até o momento do uso em experimentos de extração de RNA e de proteínas.

\subsubsection{Estresse oxidativo}

Para indução de estresse oxidativo os vermes foram tratados com concentrações crescentes de peróxido de hidrogênio $\left(\mathrm{H}_{2} \mathrm{O}_{2}\right)$ (Dinâmica) variando de $100 \mu \mathrm{M}$ a $5 \mathrm{mM}$. Para avaliar o efeito do estresse oxidativo na produção de ovos, os vermes foram cultivados em placas de 24 poços ( 1 casal por poço), contendo $2 \mathrm{~mL}$ de meio RPMI suplementado e mantidos a $37^{\circ} \mathrm{C}$ em atmosfera com $5 \%$ de $\mathrm{CO}_{2}$. A produção dos ovos foi analisada através de experimentos independentes. Para a produção total de ovos, após o tratamento com as concentrações definidas de $\mathrm{H}_{2} \mathrm{O}_{2}$, os vermes foram monitorados a cada 24 horas (total de 120 horas), sendo avaliada a produção de ovos ao longo deste intervalo de tempo. Cada experimento foi realizado em triplicata e os resultados analisados através de análise de variância one-way (ANOVA) e teste Tukey $(\mathrm{p}<0.05)$. Para os experimentos de análise de expressão gênica e proteica foi escolhida a uma concentração de $\mathrm{H}_{2} \mathrm{O}_{2}$ que não causou alterações significativas na viabilidade dos vermes. Desta forma, os vermes foram submetidos a estresse oxidativo por 0 minuto (controle), 30 minutos, 1 hora, 4 horas e 24 horas com 200 $\mu \mathrm{M}$ de peróxido de hidrogênio, a $37^{\circ} \mathrm{C}$ em atmosfera de $5 \%$ de $\mathrm{CO}_{2}$. Como controle negativo foram utilizados vermes mantidos em meio RPMI. Após os tratamentos, os vermes foram retirados do meio, lavados com meio RPMI e armazenados a $-70^{\circ} \mathrm{C}$ para extração de RNA e de proteínas.

\subsubsection{Estresse térmico}

Quanto ao estresse térmico, os vermes foram expostos a diferentes temperaturas por determinados períodos de tempo. Após perfusão, os vermes foram mantidos a $37^{\circ} \mathrm{C}$ em atmosfera de $5 \% \mathrm{CO}_{2}$ por $24 \mathrm{~h}$ para aclimatação. Posteriormente, os vermes foram cultivados em garrafas de cultura de $50 \mathrm{~mL}$ contendo meio RPMI suplementado (conforme descrito acima) pré-aquecido a $40^{\circ} \mathrm{C}$ (MOREIRA, 2008) ou $42^{\circ} \mathrm{C}$ (ARAGON et al., 2008). Os vermes foram recuperados 1 hora após cada tratamento. Como grupos controle, foram utilizados vermes expostos a $37^{\circ} \mathrm{C}$ por 1 hora. Após os tratamentos os vermes foram retirados do meio e utilizados para os experimentos subsequentes. 


\subsection{Viabilidade de vermes adultos de $S$. mansoni}

Vermes adultos pareados incubados por 24 horas com concentrações determinadas de $\mathrm{H}_{2} \mathrm{O}_{2}$ (estrese oxidativo) e vermes oriundos de estresse térmico (conforme descrito acima) tiveram sua viabilidade determinada através do ensaio de MTT. Após o período de cada tratamento em específico, cada par de vermes adultos foi transferido para placa de cultura (96well), sendo em seguida adicionado $100 \mu \mathrm{L}$ de tampão fosfato salino contendo $1 \mathrm{mg} / \mathrm{mL}$ de MTT (Sigma). Os vermes foram então incubados nesta solução por 30 min a $37^{\circ} \mathrm{C} \mathrm{em}$ atmosfera de $5 \%$ de $\mathrm{CO}_{2}$. A solução foi então removida e adicionou-se $200 \mu \mathrm{L}$ de DMSO e os vermes mantidos em temperatura ambiente por $1 \mathrm{~h}$. A absorbância foi lida em leitor de microplacas (Power Wavex 340, Bio-Tek Instruments, Winooski) no comprimento de 550 nm usando como grupos de controles negativos vermes mantidos em meio RPMI. Como controles positivos foram utilizados vermes mortos a $56^{\circ} \mathrm{C}$ por 15 minutos. O experimento foi realizado em triplicata e os resultados analisados através de análise de variância one-way (ANOVA) e teste Tukey ( $\mathrm{p}<0.05$ ) utilizando o software GraphPad v.5.0 (GraphPad Software, San Diego, Califórnia, USA). Além disso, a viabilidade também foi avaliada por microscopia onde foram analisadas as condições gerais do parasito como motilidade e mortalidade.

\subsection{Produção de espécies reativas de oxigênio (ROS) após estresse químico}

A produção ROS foi mensurada através do ensaio com NBT (CHOI et al., 2006). Neste método, ocorre a conversão oxidativa (liberação de ânions superóxido) de NBT em cristais de formazan, o qual pode ser determinado através da leitura de absorbância. $O$ aumento na absorbância indica um aumento na produção de ROS intracelular. Após estresse químico, vermes adultos pareados incubados por 24 horas com concentrações determinadas de Curcumina, IBMX e MG132 foram transferidos para placa de cultura (96-well), sendo em seguida adicionados $100 \mu \mathrm{L}$ de solução 2\% NBT (Sigma). Os vermes foram então incubados nesta solução por 1 hora á temperatura ambiente, sendo em seguida lavados duas vezes com PBS e 1 vez com metanol. Em seguida, os vermes foram dissolvidos pela adição de $120 \mu \mathrm{L}$ de $\mathrm{KOH} 2 \mathrm{M}$ e $140 \mu \mathrm{L}$ de DMSO sob agitação constante por 10 minutos a temperatura ambiente. A absorbância foi lida em leitor de microplacas no comprimento de onda de $620 \mathrm{~nm}$ (Power Wavex 340, Bio-Tek Instruments, Winooski). Como controle negativo foram utilizados vermes adultos tratados com DMSO 0,04\% por 24 horas. O experimento foi realizado em triplicata e os resultados analisados através de análise de variância one-way (ANOVA) e teste t de Dunnett $(\mathrm{p}<0.05)$. 


\subsection{Microscopia eletrônica de varredura para avaliação de danos no tegumento de} vermes adultos de $S$. mansoni oriundos de estresse oxidativo

Para análise de danos no tegumento os vermes adultos de $S$. mansoni oriundos de estresse oxidativo foram processados e analisados em microscópio eletrônico de varredura. Para este ensaio foram escolhidas duas concentrações de peróxido de hidrogênio, sendo a primeira, a concentração que provocou a diminuição de $50 \%$ da viabilidade dos parasitos após cultivo in vitro (IC50 foi calculado através de uma curva dose-resposta) e, a segunda, a menor concentração que provocou $100 \%$ de mortalidade dos parasitos. Desta forma, os vermes foram tratados por $24 \mathrm{~h}$ com $800 \mu \mathrm{M}$ e $1 \mathrm{mM}$ de $\mathrm{H}_{2} \mathrm{O}_{2}$, respectivamente. Como grupos controle foram utilizados vermes adultos de S. mansoni mantidos em meio RPMI (controle negativo) e vermes tratados com $10 \mu \mathrm{M}$ de Praziquantel por $24 \mathrm{~h}$ (controle positivo).

Após o cultivo in vitro os parasitos foram retirados do meio de cultura e transferidos para tubos eppendorf de $1,5 \mathrm{~mL}$, sendo lavados com $1 \mathrm{~mL}$ PBS pré-aquecido a $37^{\circ} \mathrm{C}$. Em seguida, a solução de PBS foi retirada e os vermes foram fixados com $1 \mathrm{~mL}$ de glutaraldeído $3 \%$ (solução de fixação), sendo os vermes mantidos em então a $37^{\circ} \mathrm{C}$ por 60 minutos. Em seguida, os vermes foram mantidos por 60 minutos a temperatura ambiente, e no final deste tempo, foram lavados novamente com $1 \mathrm{~mL}$ de PBS e armazenados em PBS a $4^{\circ} \mathrm{C}$ até o momento do uso.

Em seguida, procedeu-se o processo de pós-fixação com tetróxido de ósmio $1 \%$ em tampão fosfato salina por $2 \mathrm{~h}$ a $4^{\circ} \mathrm{C}$, seguido por lavagem com PBS $0,1 \mathrm{M}$ por três vezes. Em seguida foi realizada a desidratação crescente em etanol: $30 \%, 50 \%, 70 \%, 90 \%$ por 15 minutos, e três lavagens com etanol $100 \%$ de 20 minutos e então as amostras foram submetidas à secagem no CPD (Critical Point Dryer 030- Bal-Tec). Após o preparo das amostras os parasitos foram montados em stubs e submetidos a banho de ouro no Sputter Coater (SCD 050- Bal-Tec), e então realizadas as análises e documentação do material no microscópio eletrônico de varredura JEOL JSM-6610LV Scanning Electron Microscope operando a $25 \mathrm{kV}$. Todas as medidas foram feitas em micrômetros $(\mu \mathrm{m})$. O procedimento de pós-fixação e preparo final das amostras foi realizado no Laboratório de Microscopia Eletrônica (Departamento de Biologia Celular e Molecular e Bioagentes Patogênicos da Faculdade de Medicina de Ribeirão Preto - FMRP-USP). 


\subsection{Análises de bioinformática para os genes SmHul5 e SmUbp6}

\subsubsection{Banco de dados e análises in silico}

As análises in silico foram realizadas utilizando os bancos de dados http://www.ncbi.nlm.nih.gov/ e http://www.genedb.org/genedb/smansoni, o qual é mantido pelo The Wellcome Trust Sanger Institute e reúne sequência provenientes dos projetos genoma e transcriptoma de S. mansoni (VERJOVSKI-ALMEIDA et al., 2003; BERRIMAN et al., 2009). Inicialmente, foi realizada uma busca no banco de dados http://www.ncbi.nlm.nih.gov/, onde foram pesquisadas sequências já descritas para os genes Hul5 e Ubp6. Logo em seguida, as sequências obtidas após esta busca inicial foram utilizadas para pesquisa em banco de dados de $S$. mansoni (http://www.genedb.org/Homepage/Smansoni). As sequências que apresentaram maior identidade no genoma de $S$. mansoni foram utilizadas nas análises subsequentes.

Após a recuperação no banco de dados as sequências referentes aos genes SmHul5 e SmUbp6 foram submetidas a pesquisa BLAST no banco de dados NCBI para confirmar características de anotações e identidade com outros organismos. Logo em seguida, a sequência predita de aminoácidos foi determinada utilizando a ferramenta ORF Finder (http://www.ncbi.nlm.nih.gov/gorf/gorf.html). Posteriormente, as sequências preditas das proteínas foram submetidas a uma análise na base de dados do algoritmo PFAM disponível em http://pfam.sanger.ac.uk/ para identificação de domínios conservados. Por fim, as sequências de aminoácidos das protéinas Hul5 e Ubp6 de diversos organismos foram alinhadas utilizando o algoritmo ClustalW (http://www.ebi.ac.uk/Tools/msa/clustalw2/), e o alinhamento obtido foi utilizado para análises filogenéticas no programa MEGA 4.0 (TAMURA et al., 2007).

\subsubsection{Idealização dos oligonucleotídeos iniciadores para SmHul5, SmUbp6 e genes marcadores de estresse do proteassoma}

Com base nas sequências genômicas referentes aos genes SmHul5 e SmUbp6 bem como sequências gênicas relacionadas a genes marcadores para estresse oxidativo e térmico (Tabela 1) depositadas no banco de dados http://www.genedb.org/Homepage/Smansoni e identificadas durante a análise in silico foram idealizados oligonucleotídeos iniciadores (primers) para os genes em estudo. Primeiramente, as sequências foram submetidas à análise 
no algoritmo ORF Finder presente no site http://www.ncbi.nlm.nih.gov/gorf/gorf.html. Este algoritmo identifica a região codificadora predita do mRNA (RNA mensageiro) baseado na identificação do primeiro ATG (códon de início que codifica para o aminoácido metionina) e do primeiro códon de parada dentro da sequência codificadora do mRNA.

O desenho de primers foi realizado no programa Primer3 (ROZEN; SKALETSKY, 2000) disponível em (http://www.bioinformatics.nl/cgi-bin/primer3plus/primer3plus.cgi). A tabela 2 mostra as sequências dos oligonucleotídeos iniciadores utilizados com as respectivas temperaturas de anelamento e o tamanho dos produtos esperados. Os oligonucleotídeos foram desenhados para amplificar regiões dentro e fora de domínios conservados, sendo estes domínios indicados na tabela 1.

Os oligonucleotídeos iniciadores para os genes de alfa-tubulina (WEBSTER et al., 1992) e GAPDH (Gliceraldeído-3-fosfato desidrogenase) (MOURÃO et al., 2009) (Tabela 2) foram utilizados como controles endógenos nas reações de PCR e PCR quantitativo.

Tabela 1. Sequências gênicas referentes a enzimas acessórias ao proteassoma de $S$. mansoni e genes marcadores de estresse celular.

\begin{tabular}{ccccc}
\hline Sequência & Nome & Descrição & Domínio & $\begin{array}{c}\text { Tamanho } \\
\text { ORF }\end{array}$ \\
\hline Smp_130650 & SmHul5 & Proteína ubiquitina ligase & HECT (PF00632.20) & $4971 \mathrm{pb}$ \\
Smp_084740 & SmUbp6 & Ubiquitina peptidase específica 14 (família C19) & UCH (PF00443.24) & $1218 \mathrm{pb}$ \\
Smp_058690 & SmGPxl & Glutationa peroxidase 1 & GSHPx (PF00255.14) & $772 \mathrm{pb}$ \\
Smp_124360 & SmGPx2 & Glutationa peroxidase 2 & GSHPx (PF00255.14) & $540 \mathrm{pb}$ \\
Smp_176200.2 & SmSOD & Superóxido Dismutase (Cu-Zn) & Sod_Cu (PF00080.14) & $675 \mathrm{pb}$ \\
Smp_106930.2 & SmHSP70 & Proteína de choque térmico 70 (HSP70) & HSP70 (PF00012.4) & $2736 \mathrm{pb}$ \\
Smp_049600.4 & SmHSP40 & Proteína de choque térmico 40 (HSP40) & DnaJ (PF00226.25) & $1828 \mathrm{pb}$ \\
Smp_048430 & SmTGR & Tiorredoxina glutationa redutase & Pyr_redox_2 (PF07992.9) & $2223 \mathrm{pb}$ \\
& & & Glutaredoxin (PF00462.19) & \\
\hline
\end{tabular}


Tabela 2. Oligonucleotídeos iniciadores para amplificação dos genes referentes a enzimas acessórias ao proteassoma de $S$. mansoni e genes marcadores de estresse celular.

\begin{tabular}{|c|c|c|c|c|c|}
\hline Sequência & Nome & Forward (5'-3') & Reverse (5'-3') & $\begin{array}{c}\text { Tamanho } \\
\text { Fragmento }\end{array}$ & $\begin{array}{l}\text { Temperatura } \\
\text { de anelamento }\end{array}$ \\
\hline Smp_130650 & SmHul5 & caactggcttagctgaagttgg & gcagatgcttgtggatttgg & $148 \mathrm{pb}$ & $60^{\circ} \mathrm{C}$ \\
\hline Smp_084740 & SmUbp6 & acctggectcgtaaatcttg & gcgatatttcgtcgagcttc & $139 \mathrm{pb}$ & $60^{\circ} \mathrm{C}$ \\
\hline Smp_058690 & $\operatorname{SmGPxl}$ & ctgcaatcaattcggtggac & aattggacgecgtacttctc & $81 \mathrm{pb}$ & $60^{\circ} \mathrm{C}$ \\
\hline Smp_124360 & $S m G P x 2$ & ggtgaaaatgctattccgttg & ggggagttatcgaactgtaacg & $142 \mathrm{pb}$ & $60^{\circ} \mathrm{C}$ \\
\hline Smp_176200.2 & SmSOD & cgcagtttataacgcgactg & aaacgaccaccagcattacc & $150 \mathrm{pb}$ & $60^{\circ} \mathrm{C}$ \\
\hline Smp_106930.2 & SmHSP70 & tcgatgatccatcagtgcag & tctcctcagcggaaaacatc & $123 \mathrm{pb}$ & $60^{\circ} \mathrm{C}$ \\
\hline Smp_049600.4 & SmHSP40 & ttcagggcgaagaaagagtg & gggtttgagcttgctgttc & $142 \mathrm{pb}$ & $60^{\circ} \mathrm{C}$ \\
\hline Smp_048430 & SmTGR & catcggggattctcaaacag & tttagcagcetcctttccag & $142 \mathrm{pb}$ & $60^{\circ} \mathrm{C}$ \\
\hline \multicolumn{6}{|c|}{$\begin{array}{l}\text { Controles endógenos } \\
\end{array}$} \\
\hline M80214* & Alfa-tubulina & gaaatgcttgttggagttg & ttatcacttggcatctgtcc & $70 \mathrm{pb}$ & $60^{\circ} \mathrm{C}$ \\
\hline$* *$ & GAPDH & tcgttgagtctactggagtctttacg & aatatgagcctgagctttatcaatgg & $70 \mathrm{pb}$ & $60^{\circ} \mathrm{C}$ \\
\hline \multicolumn{6}{|c|}{ Controle de montagem de proteassomas } \\
\hline
\end{tabular}

*WEBSTER, P. J.; SETA, K. A.; CHUNG, S. C.; MANSOUR, T. E. A cDNA encoding an alpha-tubulin from Schistosoma mansoni. Molecular and Biochemical Parasitology, v. 51, p. 169-170, 1992. **MOURÃO, M. M.; DINGUIRARD, N.; FRANCO, G. R.; YOSHINO, T. P. Phenotypic Screen of Early-Developing Larvae of the Blood Fluke, Schistosoma mansoni, using RNA Interference. PLOS Neglected Tropical Diseases, 3(8): e502. doi:10.1371/journal.pntd.0000502, August, 2009.

Outro controle utilizado neste trabalho foi o oligonucleotídeo iniciador para a proteína de maturação do proteassoma (SmPOMP), a qual é conhecida como um marcador molecular indicando montagem e desmontagem de populações de proteassoma (MOREIRA, 2008).

\subsubsection{Análise da estrutura genômica dos genes $\mathrm{SmHul5}$ e SmUbp6}

As sequências do DNA genômico e do full transcript para SmHul5 e SmUbp6 foram recuperadas do banco de dados de $S$. mansoni e em seguida estas sequências foram alinhadas com auxílio do programa BLAST (http://blast.ncbi.nlm.nih.gov/). Essa análise permitiu definir as regiões dos éxons na estrutura destes genes. 


\subsection{Extração de RNA total de $S$. mansoni}

Para extração do RNA total foram utilizadas as diferentes fases do ciclo de vida do $S$. mansoni (ovos, miracídios, esporocistos, cercárias, esquistossômulos e vermes adultos) além de casais de vermes adultos oriundos dos diferentes tipos de estresse (oxidativo, químico e térmico).

Após obtenção do material biológico, as amostras foram homogeneizadas separadamente em Politron (JK IKA Labor Techniik Ultra Turrax T8) com $1 \mathrm{~mL}$ de Trizol (Invitrogen), sendo realizados 2 pulsos de 20 segundos por amostra até completa solubilização. Este processo foi realizado no gelo, sendo a mistura, em seguida, incubada por 15 min à temperatura ambiente para permitir a completa dissociação dos complexos de nucleoproteínas. Decorrido este intervalo de tempo, o extrato foi passado em seringa de $1 \mathrm{~mL}$ com agulha $26 \mathrm{G}(13 \times 4,5)$ por 3 vezes para a quebra do DNA genômico e em seguida, foi adicionado à mistura $200 \mu \mathrm{L}$ de clorofórmio. As amostras foram agitadas vigorosamente em vortéx (Phoenix AP-56) por 10 segundos e incubadas à temperatura ambiente durante 3 minutos. Posteriormente, a mistura foi centrifugada a $12000 \times \mathrm{g}$ por $15 \mathrm{~min}$ a $4^{\circ} \mathrm{C}$ (Centrifuga 5417R-Eppendorf). Após a centrifugação, obteve-se uma mistura com 3 diferentes fases: inferior fase fenol-clorofórmio, interfase e fase aquosa superior. A fase aquosa contendo o RNA foi transferida para um tubo eppendorf de $1,5 \mathrm{~mL}$ e precipitado pela adição de $500 \mu \mathrm{L}$ de isopropanol gelado, e incubado à temperatura ambiente por $15 \mathrm{~min}$. O RNA foi então recuperado por centrifugação a $12000 \times \mathrm{g}$ por $10 \mathrm{~min}$ a $4^{\circ} \mathrm{C}$. O sobrenadante foi desprezado e o precipitado lavado com $1 \mathrm{~mL}$ de etanol $75 \%$, sendo em seguida centrifugado a $7500 \times \mathrm{g}$ por 5 min a $4^{\circ} \mathrm{C}$. O precipitado final foi seco e, em seguida, foi adicionado ao pellet, $20 \mu \mathrm{L}$ de água DEPEC, sendo a amostra incubada a $56^{\circ} \mathrm{C}$ por 10 minutos, sem homogeneizar, no heat shock (VWR Scientific). Uma alíquota deste material foi avaliada em gel de agarose 1\%, para verificar a qualidade do RNA e o restante da amostra foi mantida a $-70^{\circ} \mathrm{C}$ até o momento de uso.

As concentrações dos RNAs foram estimadas em espectrofotômetro (Nanodrop Spectometer ND-1000, Thermo Scientific). A absorbância foi medida nos comprimentos de onda de 260, 280 e $230 \mathrm{~nm}$, visando à avaliação do grau de pureza das amostras, o qual foi estimado através da relação entre as razões de leituras A260/280 e A260/230 nm, onde as preparações foram consideradas apropriadas, quando o valor da razão A260/280 variou entre $1,8-2,1$. 


\subsection{Tratamento do RNA com DNAse}

As amostras de RNA total foram tratadas com RQ1 RNAse-Free DNAse (Promega), para degradar DNA contaminante proveniente da extração do RNA total. As reações com DNAse foram feitas como descrito: a $1 \mu \mathrm{g}$ de RNA total foi adicionado $1 \mu \mathrm{L}$ do tampão $10 \mathrm{X}$ da DNAse, $1 \mu \mathrm{L}$ de DNAse $\left(1 \mathrm{U} / \mu \mathrm{L}\right.$ ) e $\mathrm{H}_{2} \mathrm{O}$ em quantidade suficiente para $8 \mu \mathrm{L}$ (volume final da reação). Em seguida, a reação foi incubada a $37^{\circ} \mathrm{C}$ por 30 minutos e após este intervalo foi adicionado $1 \mu \mathrm{L}$ da solução de parada da reação (RQ1 DNAse Stop Solution), seguido por incubação a $65^{\circ} \mathrm{C}$ por 10 minutos.

\subsection{Síntese do DNA complementar pela técnica de transcrição reversa (RT)}

Cerca de $1 \mu \mathrm{g}$ de RNA total foi utilizado para realização da transcrição reversa com 50 pmoles do iniciador oligo (dT) combinado com $10 \mathrm{mM}$ de dNTPs e água tratada com DEPC para um volume final de $12 \mu \mathrm{L}$. Esta mistura foi incubada por 5 min a $65^{\circ} \mathrm{C}$, sendo adicionado em seguida o tampão da enzima, $15 \mathrm{U} / \mu \mathrm{L}$ da enzima transcriptase reversa, $0,1 \mathrm{M}$ de DTT e RNAout $40 \mathrm{U} / \mu \mathrm{L}$. Posteriormente, a amostra foi incubada em termociclador por $60 \mathrm{~min}$ a $65^{\circ} \mathrm{C}$. Após este intervalo de tempo, as amostras foram aquecidas a $85^{\circ} \mathrm{C}$ por 5 min. Para finalizar, $2 \mathrm{U} / \mu \mathrm{L}$ de RNAse $\mathrm{H}$ foram adicionados, seguidos por incubação de 20 min a $37^{\circ} \mathrm{C}$. $\mathrm{O}$ cDNA foi mantido a $-20^{\circ} \mathrm{C}$ até o momento do uso.

\subsection{Validação dos oligonucleotídeos iniciadores para os genes $\mathrm{SmHul5}$ e SmUbp6}

Inicialmente a validação dos primers foi realizada na fase de verme adulto. Para a reação de validação dos oligonucleotídeos específicos para os genes SmHul5 e SmUbp6 foram utilizados, aproximadamente $50 \mathrm{ng}$ de cDNA, tampão da enzima $1 \mathrm{X}, 1,5 \mathrm{mM}$ de $\mathrm{MgCl}_{2}, 0,2$ $\mu \mathrm{M}$ de oligonucleotídeos iniciadores específicos Forward e Reverse (SmHul5, SmUbp6), 0,2 $\mathrm{mM}$ de dNTPs e $1 \mathrm{U}$ da enzima Platinum Taq DNA polimerase (Invitrogen), para um volume final de reação de $50 \mu \mathrm{L}$. A reação de amplificação foi realizada da seguinte forma: uma etapa de desnaturação a $94^{\circ} \mathrm{C}$ por 3 minutos, seguida de 40 ciclos de acordo com o seguinte programa: desnaturação a $94^{\circ} \mathrm{C} / 1$ minuto, anelamento a $60^{\circ} \mathrm{C} / 1$ minuto, extensão a $72^{\circ} \mathrm{C} / 2$ minutos. Em seguida, $10 \mu \mathrm{L}$ da reação foram analisados em gel de agarose 1,5\% corado com GelRed $^{\mathrm{TM}}$ (Biotium).

Após reação de amplificação, o produto amplificado foi transferido para um tubo eppendorf, ao qual foram adicionados $1 / 10$ do volume de acetato de sódio $3 \mathrm{M}$ pH 7,0 e 2,5 
vezes o volume de etanol absoluto. Em seguida, a mistura foi incubada a $-20^{\circ} \mathrm{C}$ por 30 minutos e $\operatorname{logo}$ após, centrifugada durante 10 minutos a $14000 \times g$. O sobrenadante foi descartado e ao pellet foram adicionados $500 \mu \mathrm{L}$ de etanol $70 \%$. Após centrifugação de 5 minutos a $14000 \times \mathrm{g}$, o sobrenadante foi descartado e o pellet seco à temperatura ambiente. Posteriormente, o mesmo foi ressuspendido em $10 \mu \mathrm{L}$ de $\mathrm{H}_{2} \mathrm{O}$ DEPEC (RNAse free), e o produto de PCR purificado armazenado a $-20^{\circ} \mathrm{C}$ até o momento do uso.

\subsection{Sequenciamento dos nucleotídeos e análise computacional das sequências}

Para realizar o sequenciamento dos produtos de PCR foi utilizada a técnica do término do crescimento da cadeia, inicialmente desenvolvida por SANGER e colaboradores (1977). As reações de sequenciamento foram realizadas utilizando o kit Big-Dye Terminator (Applied Biosystems), de acordo com as instruções do fabricante e as reações analisadas no sequenciador automático de DNA, ABI 3100 Genetic Analyzer (Applied-Biosystems). Uma alíquota dos produtos de PCR purificados foi sequenciada nas direções "direta" e "reversa" com o auxílio dos oligonucleotídeos iniciadores M13 universal (S) ou M13 reverso (AS). As sequências obtidas foram submetidas à busca de homologia com o auxílio do algoritmo BLASTn, disponível no website NCBI (www.ncbi.nlm.nih.gov).

\subsection{Perfil de expressão de $S m H u l 5$ e SmUbp6 no ciclo de vida de $S$. mansoni e em diferentes condições de estresse do proteassoma}

Após a validação dos oligonucleotídeos iniciadores para os genes SmHul5 e SmUbp6, por reação da polimerase em cadeia, os níveis de transcritos nas diferentes fases de desenvolvimento do parasito (verme adulto, ovos, miracídio, esporocisto, cercária, esquistossômulos, machos e fêmeas) foram analisados através de PCR quantitativo. Inicialmente foram realizados ensaios para otimização dos primers assim como da quantidade ótima de cDNA a ser utilizada nas reações de quantificação relativa dos respectivos transcritos, além disso, foi realizada a curva padrão para cada transcrito no intuito de definir o valor do "threshold" (limiar de detecção), visando a obtenção de uma eficiência de $100 \% \pm$ $10 \%$ em cada reação.

Para um volume final de $10 \mu \mathrm{L}$ de reação, foram utilizados $250 \mathrm{nM}$ dos oligonucleotídeos Forward e Reverse, $5 \mu \mathrm{L}$ de SYBR green PCR Master Mix (Applied Biosystems) e $1 \mu \mathrm{g}$ de cDNA como amostra (ou água como controle negativo). Os níveis 
relativos de transcritos foram normalizados utilizando-se GAPDH (Gliceraldeído-3 fosfato desidrogenase) como o gene constitutivo. As condições de termociclagem foram uma incubação a $50^{\circ} \mathrm{C}$ por 2 minutos, seguida pela ativação da DNA polimerase a $95^{\circ} \mathrm{C}$ por 10 minutos, e 45 ciclos de desnaturação a $95^{\circ} \mathrm{C}$ por 15 segundos intercalados com anelamento e extensão a $60^{\circ} \mathrm{C}$ por 1 minuto. As reações de amplificação foram realizadas em triplicata. $\mathrm{O}$ aparelho ABI Prism 7500 (Applied Biosystems) foi utilizado para calcular os níveis de transcritos de SmHul5 e SmUbp6 normalizados com o controle endógeno GAPDH de acordo com o método $2^{-\Delta \mathrm{Ct}}$ (Applied Biosystems, 1997). As diferenças entre os grupos foram avaliadas utilizando a análise de variância one-way (Teste Tukey). Para admitir diferenças estatisticamente significativas foi considerado $\mathrm{P}<0,05$.

Além da análise de expressão de SmHul5 e SmUbp6 nas diferentes fases do ciclo de vida de $S$. mansoni, foi realizada também a análise de expressão destes genes mediante diferentes condições de estresse (oxidativo, térmico e químico) do proteassoma de S. mansoni. Para isto, os vermes oriundo de estresse químico com IBMX, MG132 e Curcumina, estresse oxidativo (peróxido de hidrogênio) e estresse térmico tiveram o RNA extraído, e o cDNA sintetizado (conforme descrito acima) foi usado como molde nestas reações de amplificação. Em todas as situações, os experimentos foram realizados em três réplicas biológicas independentes, sendo as reações preparadas em triplicata. O aparelho ABI Prism 7500 (Applied Biosystems) foi utilizado para calcular os níveis de transcritos de SmHul5 e SmUbp6. Neste caso, os níveis de transcritos foram normalizados em relação ao controle endógeno GAPDH, sendo em seguida corrigidos em relação ao grupo controle (vermes não tratados) de acordo com o método $2^{-\Delta \Delta C t}$ (LIVAK; SCHMITTGEN, 2001). Como controle de qualidade das reações, o coeficiente de variação máximo permitido nas triplicatas foi de $2 \%$, caso contrário, os experimentos foram repetidos. A análise estatística foi realizada utilizando o software GraphPad v.5.0 (GraphPad Software, San Diego, Califórnia, USA). As diferenças entre o grupo controle e tratados foram avaliadas utilizando a análise de variância one-way (Teste Tukey). Para admitir diferenças estatisticamente significativas foi considerado $\mathrm{P}<0,05$.

3.17. Perfil de expressão de SmGPx1, SmGPx2, SmSOD, SmTGR, SmHsp70 e SmHsp40 após estresse químico com Curcumina, IBMX e MG132

O nível de transcritos para os genes glutationa peroxidase 1 (SmGPxl), glutationa peroxidase 2 (SmGPx2), superóxido dismutase (SmSOD), tiorredoxina glutationa redutase $(S m T G R)$ e para as proteínas de choque térmico Hsp70 (SmHsp70) e Hsp40 (SmHsp40) foi 
analisado após indução de estresse químico com Curcumina, IBMX e MG132. Para isto, os vermes oriundo de estresse químico tiveram o RNA extraído, e o cDNA sintetizado foi usado como molde nestas reações de amplificação. Em todas as situações, os experimentos foram realizados em três réplicas biológicas independentes, sendo as reações preparadas em triplicata. O aparelho ABI Prism 7500 (Applied Biosystems) foi utilizado para calcular os níveis de transcritos dos genes, sendo então normalizados em relação ao controle endógeno GAPDH, e em seguida corrigidos em relação ao grupo controle (vermes não tratados) de acordo com o método $2^{-\Delta \Delta C t}$ (LIVAK; SCHMITTGEN, 2001). Como controle de qualidade das reações, o coeficiente de variação máximo permitido nas triplicatas foi de $2 \%$, caso contrário, os experimentos foram repetidos. A análise estatística foi realizada utilizando o software GraphPad v.5.0 (GraphPad Software, San Diego, Califórnia, USA). As diferenças entre o grupo controle e tratados foram avaliadas utilizando a análise de variância one-way (Teste Tukey). Para admitir diferenças estatisticamente significativas foi considerado $\mathrm{P}<0,05$.

\subsection{Obtenção do extrato proteico solúvel total de vermes adultos de $S$. mansoni}

Vermes adultos de $S$. mansoni submetidos aos diferentes tratamentos de estresse foram mantidos em cultivo como descrito anteriormente e posteriormente, foi realizada a extração de proteínas totais destes parasitos. Para isto, as amostras foram homogeneizadas em $300 \mu \mathrm{L}$ de tampão de extração contendo Tris $25 \mathrm{mM}$, pH 7,5, 0,5\% glicerol, $1 \mathrm{mM}$ DTT (GE Healthcare) e $1 \mathrm{X}$ cocktail de inibidor de proteases (Sigma) através de cinco pulsos de 10 segundos em sonicador (Vibra Cell SONICS \& MATERIALS INC. DANBURY, CT USA), com intervalos de 10 segundos em gelo. Posteriormente, as amostras foram centrifugadas por 1 hora a $20800 \times \mathrm{g}$, a $4^{\circ} \mathrm{C}$, e o sobrenadante foi transferido para outro tubo. Posteriormente, as amostras foram novamente centrifugadas por 30 minutos a $4^{\circ} \mathrm{C}$ a $15000 \times \mathrm{g}$ e o sobrenadante armazenado a $-70^{\circ} \mathrm{C}$ até o momento do uso. A concentração proteica total foi determinada segundo o Método de Bradford, conforme descrito pelo fabricante.

\subsection{Western Blotting para detecção de subunidades $\alpha$ do proteassoma}

Para a realização de Western Blotting foram utilizadas $25 \mu \mathrm{g}$ de proteínas totais de vermes adultos de $S$. mansoni oriundas dos tratamentos de estresse oxidativo. Primeiramente, as proteínas foram separadas por eletroforese em gel SDS-PAGE 12\% e, logo após, transferidas em tampão (48 mM Tris-base, $192 \mathrm{mM}$ glicina, 20\% de metanol, 0,0375\% de 
SDS, pH 9,2) para membranas de nitrocelulose Hybond ${ }^{\mathrm{TM}}$ (Amersham Biosciences - GE Healthcare). Em seguida, as membranas foram lavadas em temperatura ambiente por 5 minutos em solução de TBS-T e em seguida bloqueadas em solução de 5\% de leite desnatado em TBS-T por $1 \mathrm{~h}$ a temperatura ambiente. Após o bloqueio, as membranas foram lavadas por 4 vezes em solução de TBS-T sendo uma lavagem inicial de 10 minutos seguida por três lavagens de 5 minutos a temperatura ambiente. Posteriormente, as membranas foram incubadas overnight com os anticorpos primários específicos para subunidades do proteassoma (anticorpo de camundongo anti-20S humano, clone MCP231 (subunidades $\alpha-1$, 2, 3, 5, 6 e 7) (Biomol - PW8195) anti-IgG na diluição 1:2000), anti-19S (anticorpo de camundongo anti-19S humano subunidade não-ATPase RPN10 (Millipore - 04-259) anti-IgG na diluição de 1:2000) ou actina (anticorpo de camundongo anti-actina humana, clone C4 (Millipore - MAB1501) anti-IgG na diluição 1:3000).

Após a incubação com os anticorpos primários, as membranas foram lavadas por 4 vezes em TBS-T conforme descrito acima e incubadas com anticorpo secundário (anticorpo de galinha anit-IgG de camundongo na diluição 1:5000) conjugado com fosfatase alcalina por $1 \mathrm{~h}$ a temperatura ambiente. Posteriormente, as membranas foram reveladas na ausência de luz com auxílio do Kit BCIP/NBT Sistema de Substrato Líquido (Sigma). Como marcador de peso molecular de proteínas foi utilizado PageRuler ${ }^{\mathrm{TM}}$ Prestained Protein Ladder (Thermo Scientific).

\subsection{Proteoma para estresse oxidativo e estresse térmico}

\subsubsection{Preparo das amostras e reidratação das "strips"}

Para realização de eletroforese bidimensional foram utilizadas $300 \mu \mathrm{g}$ de proteínas totais, sendo os procedimentos realizados conforme descrito abaixo. Antes da realização da etapa de focalização isoelétrica ( $1^{\circ}$ dimensão) cerca de $25 \mu \mathrm{g}$ de proteínas totais oriundas de estresse oxidativo (vermes adultos tratados $200 \mu \mathrm{M}$ de peróxido de hidrogênio por $24 \mathrm{~h}$ ) e estresse térmico $\left(42^{\circ} \mathrm{C}\right.$ por $\left.1 \mathrm{~h}\right)$ foram resolvidas em gel SDS-PAGE $12 \%$ para avaliar a qualidade das proteínas.

Após este procedimento inicial, foi realizada a etapa de reidratação das "strips" (fitas de gradiente imobilizado - Immobiline ${ }^{\mathrm{TM}}$ DryStrip pH 3-10, $13 \mathrm{~cm}$ ) (GE Healthcare), na qual aproximadamente $60 \mu \mathrm{L}(300 \mu \mathrm{g})$ de proteínas foram mixados com $1 \mathrm{~mL}$ de solução de 
reidratação (Uréia 7M, Tiouréia 2M, CHAPS 4\%, azul de bromofenol 0,001\%) contendo DTT $(0,3 \%$ w/v), IPG buffer $(0,5 \%$ v/v) e $12 \mu \mathrm{L}$ de $1 \mathrm{X}$ cocktail inibidor de protease (Sigma). Logo em seguida, esta solução foi mixada com as proteínas totais de vermes adultos de $S$. mansoni e colocada em contato com as "strips" em placa de reidratação, sendo cobertas com $2 \mathrm{~mL}$ de óleo mineral (Plus One Dry Strip Cover Fluid / GE - Heatlhcare), e reidratadas por 16 h em temperatura ambiente.

\subsubsection{Focalização isoelétrica}

Nesta etapa, as "strips" foram transferidas para canaletas do aparelho Ettan IPGphor 3 (GE Healthcare) e cobertas com $9 \mathrm{~mL}$ de óleo mineral (Plus One Dry Strip Cover Fluid / GE - Heatlhcare). As condições da focalização isoelétrica foram: $1^{\circ}$ passo: $500 \mathrm{~V}, 1$ h e $500 \mathrm{Vh}$; $2^{\circ}$ passo: $1000 \mathrm{~V}, 1$ h e $800 \mathrm{Vh} ; 3^{\circ}$ passo: $8000 \mathrm{~V}, 2: 30$ h e $11300 \mathrm{Vh} ; 4^{\circ}$ passo: $8000 \mathrm{~V}, 30$ minutos e $3500 \mathrm{Vh}$ e $5^{\circ}$ passo: $2000 \mathrm{~V}, 5 \mathrm{~h}$ e $10000 \mathrm{Vh}$, sendo $50 \mathrm{~mA}$ por "strips" a $20^{\circ} \mathrm{C}$. Após o processo de focalização, as "strips" foram armazenadas a $-70^{\circ} \mathrm{C}$ até o momento do uso.

\subsubsection{Eletroforese SDS-PAGE}

Para o processo de $2^{\circ}$ dimensão (eletroforese SDS-PAGE), as "strips" foram equilibradas com uma solução de equilíbrio (Tris-HCl 50 mM pH 8,8, Uréia 6 M, Glicerol $30 \%$ (v/v) e SDS 2\%), contendo DTT (10 mg/mL) ou iodoacetoamida (25 mg/mL). Para isto, as "strips" foram colocadas em tubos de ensaio de $15 \mathrm{~mL}$ contendo $7 \mathrm{~mL}$ da solução de equilíbrio com $10 \mathrm{mg} / \mathrm{mL}$ de DTT e mantidas sob agitação de $80 \mathrm{rpm}$ em shaker (VERTEX, VS-2000A - VDRL) a temperatura ambiente por 15 minutos. Após este tempo, a solução contendo DTT foi retirada e adicionou-se $7 \mathrm{~mL}$ de solução de equilíbrio contendo $25 \mathrm{mg} / \mathrm{mL}$ de iodoacetoamida, sendo as "strips" incubadas novamente por 15 minutos a temperatura ambiente sob agitação em shaker como descrito anteriormente.

Após este passo, foi realizada a segunda dimensão em gel SDS-PAGE 12,5\% (Acrilamida 40\%, Bisacrilamida 2\%, Tris- $\mathrm{HCl} 1,5 \mathrm{M} \mathrm{pH} \mathrm{8,8,} \mathrm{SDS} \mathrm{10 \% ,} \mathrm{Perssulfato} \mathrm{de}$ amônio $10 \%$ e TEMED). A corrida eletroforética foi realizada em tampão Tris $25 \mathrm{mM}$, Glicina 192 mM pH8,3 e SDS 0,1\% (w/v) sob a voltagem de 20 mA/gel no sistema SE 600 Ruby (GE Healhcare). Em seguida, os géis foram fixados em temperatura ambiente com solução de fixação $\mathrm{G} 250\left(\mathrm{H}_{2} \mathrm{O} 47 \%\right.$, ácido fosfórico $3 \%$ e etanol 50\%) por $1 \mathrm{~h}$ sob agitação 
sendo, depois corados com solução de Coomassie Brilliant G-250 (Sigma) por três dias. Logo após, os géis foram escaneados no aparelho ImageScanner e as digitalizações foram realizadas em 300 dpi e 16 bits de resolução usando LabScan software (GE Heathcare). Para cada amostra foram feitas triplicatas de géis, sendo as imagens analisadas através do software ImageJ (NATALE et al., 2011) para verificar a expressão diferencial das proteínas, e após esta análise os spots proteicos foram recortados e encaminhados para identificação por espectrometria de massas.

\subsection{Identificação de proteínas por Espectrometria de massas}

\subsubsection{Preparo das amostras}

Após identificação das proteínas diferencialmente expressas os spots foram recortados do gel 2D e descorados usando solução de Destain (metanol 50\% : ácido acético 2,5\%) por $3 \mathrm{~h}$ a temperatura ambiente. Em seguida, a solução de Destain foi retirada e os spots desidratados por duas vezes com $200 \mu \mathrm{L}$ de acetonitrila $100 \%$ por 5 minutos a temperatura ambiente. Em seguida, o excesso de solução de acetonitrila foi evaporado com o auxílio de Speed Vacuum ${ }^{\circledR}$ por 3 minutos. Logo em seguida, as amostras foram reduzidas com solução de $10 \mathrm{mM}$ de DTT em bicarbonato de amônio $100 \mathrm{mM}$ por 30 minutos a temperatura ambiente. Decorrido este intervalo, solução de DTT foi retirada e os spots foram tratados com solução de iodoacetoamida $50 \mathrm{mM}$ em bicarbonato de amônio $100 \mathrm{mM}$ por 10 minutos a temperatura ambiente. $\mathrm{O}$ excesso de solução de iodoacetoamida foi retirado e os spots desidratados com $200 \mu \mathrm{L}$ de acetonitrila $100 \%$ por 5 minutos a temperatura ambiente, sendo após este período reidratados com $200 \mu \mathrm{L}$ de bicarbonato de amônio $100 \mathrm{mM}$ por 10 minutos.

Em seguida, os spots foram novamente desidratados por duas vezes com $200 \mu \mathrm{L}$ de acetonitrila $100 \%$ por 5 minutos a temperatura ambiente, sendo o excesso de solução de acetonitrila evaporado em Speed Vacuum ${ }^{\circledR}$ por 3 minutos. Por fim, as amostras foram tripsinizadas com $20 \mathrm{ng} / \mu \mathrm{L}$ de tripsina (Promega) em bicarbonato de amônio $50 \mathrm{mM}$, overnight a $37^{\circ} \mathrm{C}$ e extraídas do gel com a utilização de duas soluções de extração (Solução 1: ácido fórmico 5\%; Solução 2: ácido fórmico 5\% em acetonitrila 50\%), sendo cada processo de extração realizado por 10 minutos a temperatura ambiente. Em seguida, as amostras foram evaporadas em Speed Vacuum ${ }^{\circledR}$ por aproximadamente 40 minutos, ressuspendidas em ácido 
fórmico $0,1 \%$, centrifugadas por 5 minutos a $10000 \times$ g e submetidas a espectrometria de massas para identificação.

\subsubsection{Espectrometria de massas}

Os peptídeos obtidos a partir da digestão foram ressuspendidos em $12 \mu \mathrm{L}$ de ácido fórmico $0,1 \%$ e, aproximadamente $4,5 \mu \mathrm{L}$ de proteínas digeridas foram injetadas em uma coluna analítica C18 1,7 $\mu \mathrm{m}$ BEH $130(100 \mu \mathrm{m}$ x 100 mm) RP-UPLC (NanoAcquity UPLC, Waters) acoplada com um espectrômetro de massas Nano-Electrospray Q-Tof Ultima API (MicroMass/Waters), com uma taxa de fluxo de 0,6 $\mu \mathrm{L} / \mathrm{min}$. Uma coluna de captura Symmetry C18 (180 $\mu \mathrm{m}$ x $20 \mathrm{~mm})$ foi usada para dessalinização das amostras com uma taxa de fluxo de $5 \mu \mathrm{L} /$ min por 2 minutos. O gradiente foi de $15-90 \%$ de acetonitrila em $0,1 \%$ de ácido fórmico durante 10 minutos. O aparelho foi operado em modo MS positivo, com a aquisição de dados contínua a partir de uma relação de massa-carga (m/z) 100-2000Da, a uma velocidade de varredura de $1 \mathrm{~s}$ e um atraso de inter-varredura de $0,1 \mathrm{~s}$.

Os dados obtidos por meio do espectrômetro de massas Q-Tof Ultima API (MicroMass/Waters) foram processados usando o programa Mascot Distiller v.2.3.2.0, 2009 (Matrix Science Ldt.), e as proteínas foram identificadas correlacionando os dados obtidos com os dados de $S$. mansoni depositados no banco de dados NCBI (http://www.ncbi.nlm.nih.gov/), sendo os parâmetros do MASCOT definidos da seguinte forma: banco de dados de $S$. mansoni (setembro de 2011); clivagem com tripsina, uma falha de clivagem, modificação fixada (carbamidometilação $(\mathrm{C})$ ), modificação variável (oxidação (M)), tolerância de peptídeos $(0,1 \mathrm{Da})$ e tolerância de fragmentação de íons MS/MS de 0,1 Da. Os resultados foram considerados significantes com uma probabilidade permitida para um acerto aleatório de $\mathrm{P}<0,05$, de acordo com MASCOT. Com as sequências de aminoácidos das proteínas identificadas pelo MASCOT, foram realizadas análises in silico para confirmar a identidade destas proteínas no banco de dados de $S$. mansoni (http://www.genedb.org/Homepage/Smansoni).

\subsection{Categorização das proteínas diferencialmente expressas}

Após obtenção das sequências de aminoácidos das proteínas diferencialmente expressas oriundas de estresse oxidativo e térmico, foi utilizando o programa online Blast2GO (www.blast2go.org) para realização de análise de ontologia. O BlastX foi feito 
usando o NCBI blast server URL (http://www.ncbi.nlm.nih.gov/Blast.cgi), com e-value esperado de 1,0E-3 e no modo QBlast. Cada proteína diferencialmente expressa e identificada foi classificada de acordo com o processo biológico, componente celular e função molecular utilizando a anotação do Gene Ontology (GO), que foi obtido do banco de dados AMIGO (http://www.godatabase.org/cgi-bin/amigo/go.cgi). 
4. Resultados 


\section{Resultados}

\subsection{Caracterização dos genes $\mathrm{SmHul5}$ e SmUbp6}

\subsubsection{Bioinformática: Análises in silico}

A sequência para o gene SmHul5 (Smp_130650) foi recuperada do banco de dados de Schistosoma mansoni disponível em (http://www.genedb.org/Homepage/Smansoni). Esta sequência apresenta um tamanho de 4971 bp e a análise da sequência predita de aminoácidos realizada pelo programa ORF Finder (NCBI) revelou uma região codificadora (ORF) de 1656 aminoácidos para essa sequência (Figura 7). Além disso, na sequência predita de aminoácidos para Smp_130650 foram identificados dois domínios conservados: um domínio IQ (Calmodulin-binding motif - SM00015) localizado entre os aminoácidos 43 e 65 e um domínio HECT (HECT domain ubiquitin-transferase - PF00632.20; SM00119) presente entre os aminoácidos 1075 a 1394 na proteína (Figura 7).

1 MYSFEGNYKSKRSLVFHTQKLSTHALVQKTREERRSRENMVKOERSATKIORCIRDYVERIKUKRYFIELFNELSNQLGDTINKSDFNVEHEFEHKLMKLLQCFNTCYRGKSPDQR

118 HLFTVCRLLLSKHGKDAOISWLTNGSMDHIFTLGNSLLINIKYLSNLPSLTPSSNYTLPIRIFEELFNIFIGTSSSTKISLYSKHLYFSIEWICRYLSNHHYFNYLAYFIDQQLPSTVGYFQDVI

243 TQSRVFELVEFFLPKARAFINLLIAPLKCASNLSGNSSQFSNPMVDLYRELVFTALNDILTPAIDDYNTYTIGERVVRSVGIEMFKLPNIHQIVINGCLTEVENKNSQLNTEQRQQQPHN

364 GTISLIPSINL LHLFVTVAIPGMLVKCDPTTITLSSTVHTAESSMTODTDEDDDDNHEEAVTEEEGGDESLPVHLATESYTHYTWSGSPLEAAIIRFVAIVMFMRCLTEPHL PIVRPITNHK

486 PLQLRSGQEEELSDDDDNKIDDNHNTVKGVGINDQEMNMSAEFTRNTNNCSIISEDLSFQPITQLKKISVSLSHSLPALAASALSTVENFTSDLDNPDKLELIHSSSYLHYCLSQVCGLS

607 RTSLIRINSTYSQHTIYLRCLWKLIENTKCSDKSTTINYSDPNMYSLLNILCSGELPSHLMELQSYLPLIFTFADCLHHRLLCLTDSEICDISSEVNYTNSDDYRHQQSINNNSEPSRGGCGFR

731 ADELLHVGARLRDLMLGLIDLSHPDQVPKRTRNLQTDTHCTESMEQPNYSAVIRRIKQWVEMTDLGNSPGGDLLMRNTEWSIPDLRVLLYCWCSLLRQIERLVFQIYDWDRRCRRQ

848 QDISLPIYLLHNPQTTTTTMTCTASTNVSSPFSSPSSSITDIARVTNSPRLPIGTPSVSQTFWLKDNLFDLLNTTESQSSWFENRGYQDTLALADAPFGYYSILNPDRNQAVLESFSLSNRQ

971 IRQILLLKKVPFVIPFEKRVKLFKILINDDSTYNRNPFRRIYNISNQPSVPLIVRRTHLYEDGFEKLSKENVPNLHQRLKVTFLNPTGLAEVGIDGGGLSREFLIEIIRAGEDPTRGEIYAS

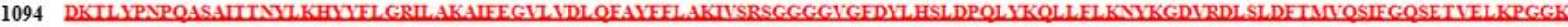

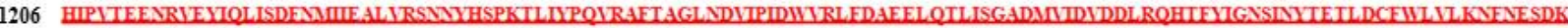

1321 BSELREVTACSRPPMIFERDLORPESTOIDEIERLPTASTCTNLLKLPNERNHIIRERLLYALNANAGEEYGLTMKSLQIEETQRQHFLRTINQRKHQSYPINFHYDQLLAQLIKE

1439 DGHIEVNLMIPKSTVNQQTYRWDECSNPTALNKSIQLRRIRHIHDCNNIIKNNNNNTVQLVENIFYPTNNNSDIDMITLNTDRQKSRKSQFSPRCSYIPKEKSSSSISSLDENEIDEVQKK

1561 LNNLKSLFQVKNQINSSSTDNDNNHNTNNIDEQLFNTSTEVNLPQTDVKNTEDVGGKIDECDQGQNLPNYATFSVKKSHEYAVRNWLLSNFNHI 1656

Figura 7. Sequência de aminoácidos predita para SmHul5 (Smp_130650). A sequência apresenta 1656 aminoácidos, sendo representado em vermelho o domínio HECT de ligase de ubiquitina (HECT domain ubiquitintransferase - PF00632. 20; SM00119) e em verde é mostrado o domínio IQ (Calmodulin-binding motif - SM00015). 
O domínio IQ foi identificado somente quando a sequência predita de aminoácidos foi pesquisada no programa SMART (http://smart.embl-heidelberg.de/). Este domínio é composto por 23 aminoácidos e apresenta um núcleo conservado importante para interação com outras proteínas como calmodulina, proteínas EF-hand e cadeia leve da miosina. Este domínio adicional sugere outra função para SmHul5 além da atividade de transferase de ubiquitina.

A sequência da proteína Hul5 é conservada entre os organismos como demonstrado pela análise de homologia realizada pelo algoritmo BLASTp (NCBI). Esta análise revelou que a sequência de SmHul5 apresenta uma ORF com $76 \%$ de identidade com a ORF de $S$. japonicum (Tabela 3). Da mesma forma, podemos observar após o alinhamento das sequências preditas de aminoácidos para a proteína Hul5 dos diferentes organismos que o domínio HECT é muito conservado entre organismos (Figura 8). Conforme observado na figura 9, as sequências da proteína Hul5 de Schistosoma mansoni e Schistosoma japonicum foram agrupadas em um mesmo clado revelando a homologia entre as sequências.

Tabela 3. Conservação da proteína Hul5 nos diferentes organismos

\begin{tabular}{cccc}
\hline Organismo & Número de acesso & Cobertura (\%) & Identidade (\%) \\
\hline \multirow{2}{*}{ Mus musculus } & SmHul5 (Smp_130650) & & \\
Drosophila melanogaster & AAH21525. 1 & 26 & 45 \\
Homo sapiens & NP_611896.1 & 25 & 47 \\
Schistosoma japonicum & AAX26342.2 & 26 & 45 \\
Aedes aegypti & XP_001663643.1 & 25 & 76 \\
Culex quinquefasciatus & XP_001844549.1 & 42 & 46 \\
\hline
\end{tabular}

Assim como para o gene SmHul5, a sequência para o gene SmUbp6 foi recuperada do banco de dados Schistosoma mansoni, sendo encontrada uma sequência (Smp_084740) com 1218 pb. Além disso, a sequência para SmUbp6 apresenta uma ORF predita composta por 405 aminoácidos e a busca por domínios revelou a presença de um domínio único conservado presente entre os aminoácidos 40 e 402 (Figura 10). Esse domínio, UCH (Ubiquitin carboxyl-terminal hydrolase - PF00443.24) é altamente conservado entre os organismos (Figura 11). 
Hul5 Aedes_asgypti

Hul5 Culex_quinquefarciatus

Hul5 Drosophila_melanogaster

Hul5 Mus_musuculus

Hul5 Homo_sapiens

Hul5 Schistosma_mansoni

Hul5 Schistosoma joponicun

Hul5 Aedes_aegypti

Hul5 Culex_quinguefarciatus

Hul5 Drosophila_melanogaster

Hul5 Mus_musuculus

Hul5 Homo_sapiens

Hul5 Schistosma_mansoni

Hul5 Schistosoma japonicun

Hul5 Aedes_asgypti

Hul5 Culex_quinquefasciatus

Hul5 Drosophila melano gaster

Hul5 Mus_musuculus

Hul5 Homo_sqpiens

Hul5 Schistosma_mansoni

Hul5 Schistosoma japonicun

Hul5 Aedes_aegrpti

Hul5 Culex_quinquefasciatus

Hul5 Drosophila_melanogaster

Hul5 Mus_musuculus

Hul5 Homo_sapiens

Hul5 Schistosma mansoni

Huls Schistosoma_japonicuon

Hul5 Aedes_asgupti

Hul5 Culex_quinquefarciatus

Hul5 Drosophila_melanogaster

Hul5 Mus_musuculus

Hul5 Homo_sapiens

Hul5 Schistosma_mansoni

Hul5 Schistosoma japonicwon
HICCT (domain ubiquitin-transforase)

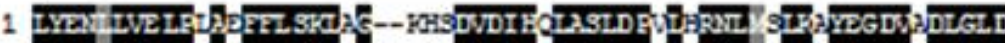

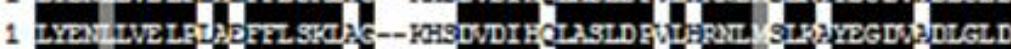

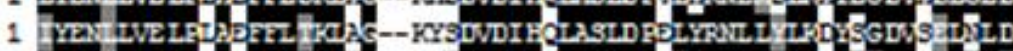

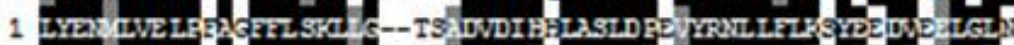

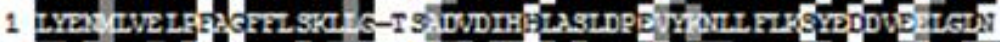

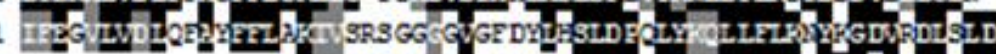

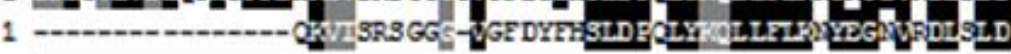

HIFCT (domain mbiquitin-transferase)

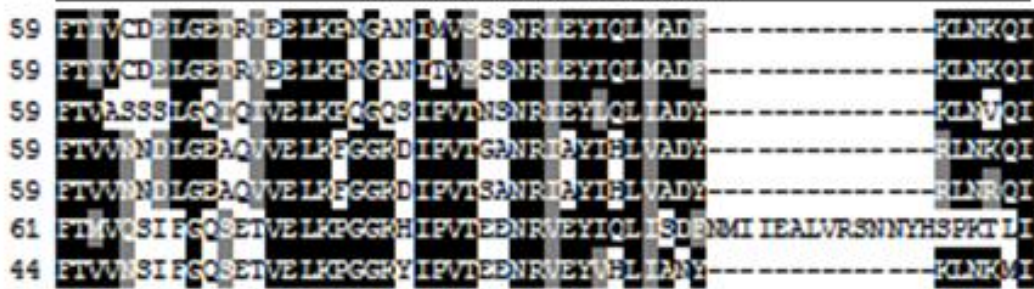

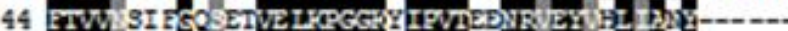

HECT (domain ubiquirin-transferase)

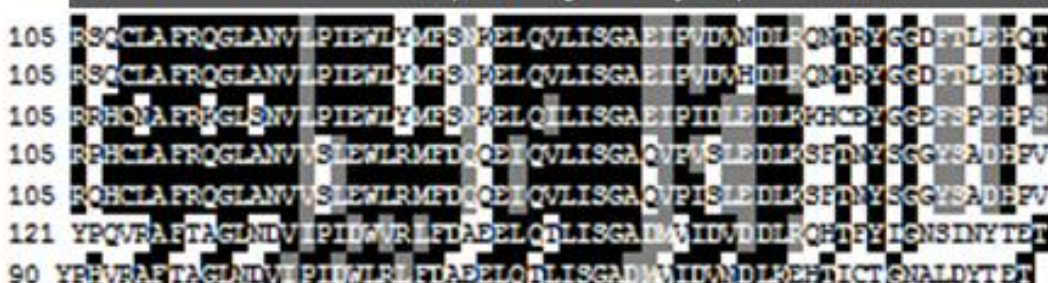

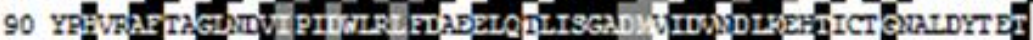

HECT (domin nbiquitin-tranfforase)

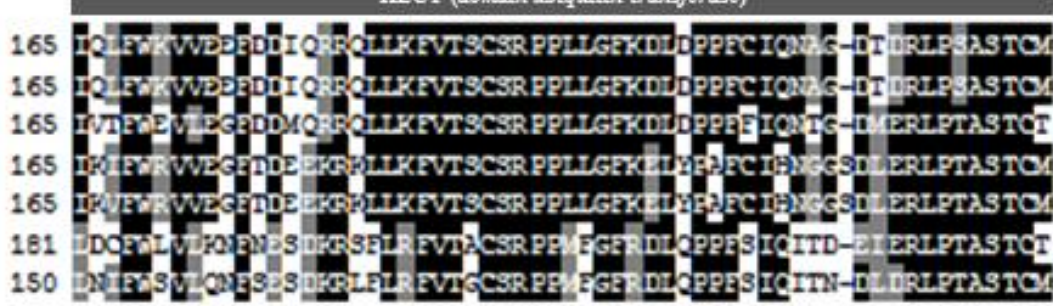

HIFCT (domain ubiquitin-trangferase)

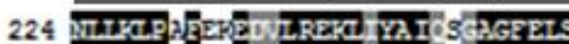

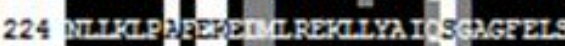

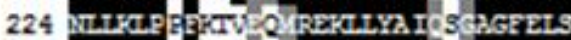

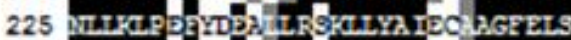

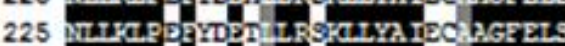

240 RTIKP

209 arr:Lp:

Aminoácidos idênticos

Aminoácidos conservados

Figura 8. Alinhamento da sequência da proteína SmHul5 (Smp_130650) com sequências ortólogas. As sequências preditas de aminoácidos para cada um dos organismos foram recuperadas através do algoritmo BLASTp no banco de dados do NCBI e alinhadas com a sequência Smp_130650 usando ClustalW. 


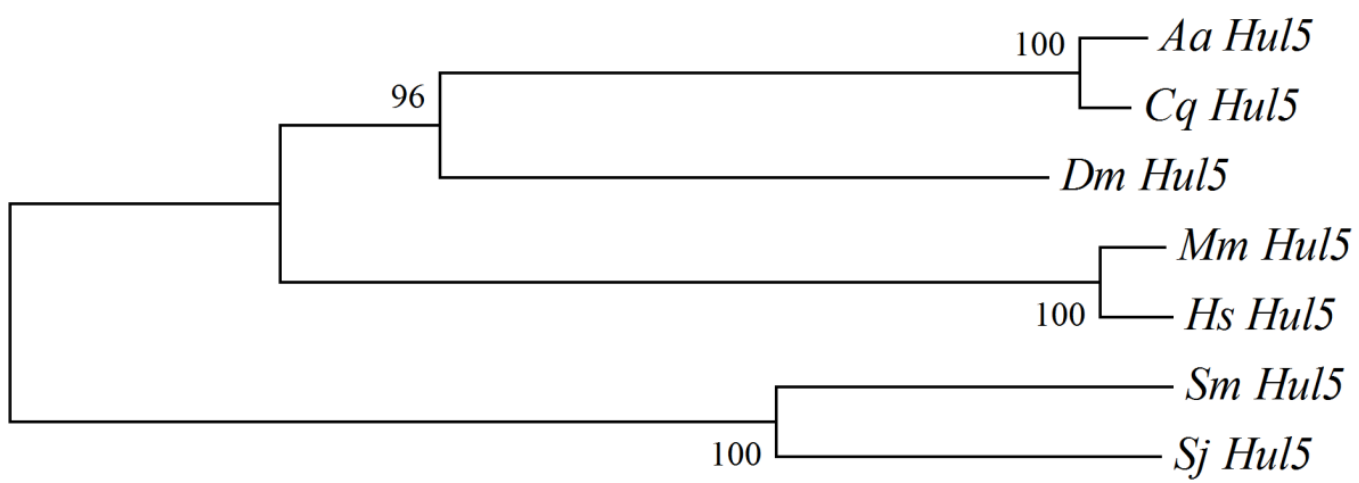

Figura 9. Filogenia entre sequências homólogas à proteína SmHul5 (Smp_130650). O alinhamento das sequências preditas de aminoácidos da proteína de cada organismo foi realizado utilizando o algoritmo CLUSTALW. Para confecção da árvore filogenética foi utilizado o Método Neighbor-Joining (NJ), sendo utilizado o teste de Boostrap para 1000 replicatas. A porcentagem de árvores replicadas nas quais os taxa foram agrupados juntos é demonstrada na árvore. As posições contendo gaps foram eliminadas do conjunto de dados analisados. As análises filogenéticas foram conduzidas no programa MEGA 4.0. Mm: Mus musculus; Sj: Schistosoma japonicum; Sm: Schistosoma mansoni; Dm: Drosophila melanogaster; Aa: Aedes aegypti; Hs: Homo sapiens; Cq: Culex quinquefasciatus.

1 MFIIKGINIMLVGSVDEIPISETPCLDNSKVAHSTEDSIKIPPGLVNLGNTCIMNAAVOLLESIPELRIALOI

74 CREPOTSPDSPNLGSLCESLKELENSLSKTEKPVTPLLELTCLHSVCPOEAARASSSDASKSAPGALSMIS

145 RGEEOODASECWVTELIRALOSSKIISOVYASTVSLPPSELTTSOWNPVDRELTGOLSCKLRCTESDEPE

214 TDSLETETOLSCEMHODVKYLITGIRNGLTGNLTKHSSLLDRNAVYKRESLISRLPAVICCIHEVRFFYK

283 EDKOINAKILKDVKEPLTLDMHEFCTPELOOKLLPMREKORLKEDEVANPSSOTNTEKSKPDSVOPDP

351 EONPDLYEPNFEADDPGSNNSGYYELOGVLSHOGRTSTSGHYVAWVKKOGMLFEV 405

Figura 10. Sequência de aminoácidos predita para SmUbp6 (Smp_084740). A sequência apresenta 405 aminoácidos, sendo representado em vermelho o domínio UCH (Ubiquitin carboxyl-terminal hydrolase - PF00443.24).

A sequência da proteína Ubp6 é conservada entre os organismos como demonstrado pela análise de homologia realizada pelo algoritmo BLASTp (NCBI). Esta análise revelou que a sequência de SmUbp6 apresenta uma ORF com $84 \%$ de identidade com a ORF de S. japonicum (Tabela 4). 
Ubp6Mus musculus Thp 6 Homo sapiens Ubp6Danio rerio Ubp6Drosophila melanogaster Ubp6Schistosoma mansoni Ubp6Schistosoma_japonicum

Ubp6Mus musculus Ubp6 Homo- sapiens Ubp6Danio rerio

Ubp6Drosophila melanogaster Ubp6Schistosomá mansoni Ubp6Schistosoma japonicum

Uop6Mus musculus Ubp6 Homo sapiens Ubp6Danio rerio

Tho6 Drosophila melanogaster Ubp6Schistosomä mansoni Ubp6Schistosoma_japonicum

Ubp6Mus musculus Tbp6 Homo sapiens Ubp6Danio rerio Ubp6Drosophila melanogaster Ubp6Schistosoma manson Ubp6Schistosoma_japonicum

Ubp6Mus musculus Ubp 6 Homo sapiens Ubp6Danio rerio Ubp6Drosophila melanogaster Ubp6Schistosomā mansoni Ubp6Schistosoma_japonicum

Tbp6Mus musculus Ubp6Homo sapiens Ubp6Danio rerio

Ubp6 Drosophila melanogaster Ubp6Schistosomä manson: Ubp6Schistosoma_japonicum

Ubp6Mus musculus Ubp6 Homo sapiens Ubp6Danio rerio Ubp6Drosophila_melanogaster Ubp6Schistosoma manson: Ubp6Schistosoma_japonicum

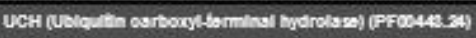

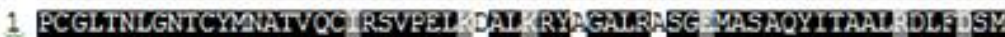
PCGLTNLGNTCYMATVQCIRSVPEL DAL RYAGALASG MASAQYITAALRDLADSM PCGLTNLGNTCYAATVOCLRSVPEL GAT RYSGALRS SGANAPSQYITAALRDL YT SY

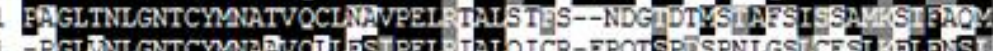

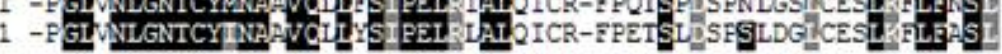

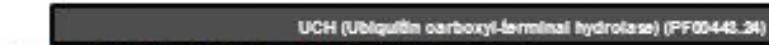

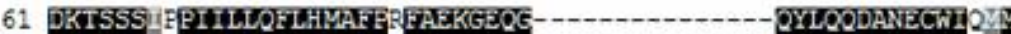

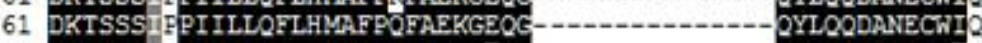

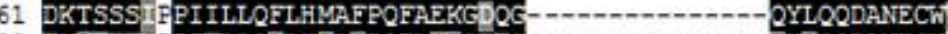

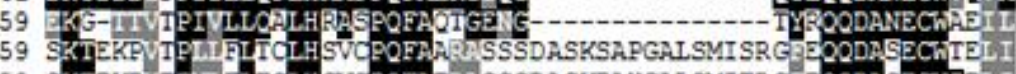
59 SKTEKPUTEVIFLICLHSVOPQFATPRSSSDASKPAHGALSMITRGBEQQDASECWTELI

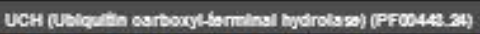

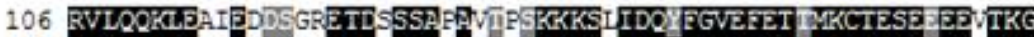
106 RVLOOKLEAIEDDSVRETDSSSASAMUPSKKKSIIDQFEGVEFET TYKCTESE EEVTKG

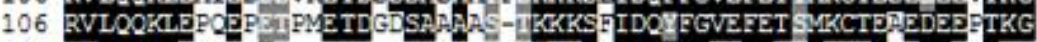

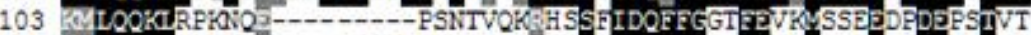
119 EALOSSKIDSQVYAS---TVSLPPSFLTISOWNPVFFLTGLLSCKLCTES-DEPETDS 119 BArd

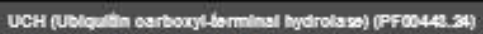

166 FENQLQLSCFINQEVKY I T TGLKLRLQE ITR OSPTLQRNASYIKSSKISRLFAYLTIQY 166 KENQLOLSCEINOEVKYLFTGLKLRLOE IT KSPTLORNA YIKSSKISRLPAYLTIOY 165 TESOLQLSCFINQEVKY D TGLRLRLQED IT K ASSLORNA YIKSSKI SRLPAYPTVOY

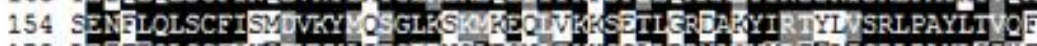

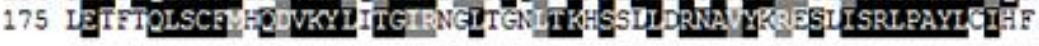

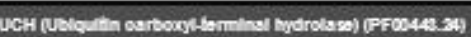

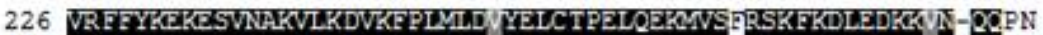

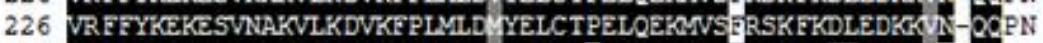
225 VR FFYKEKESVNAKVLKDVKFPLYLD YELCT SELOEKMNS RSKFKDIEDKKIEKOCKS

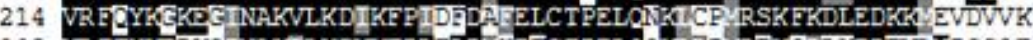

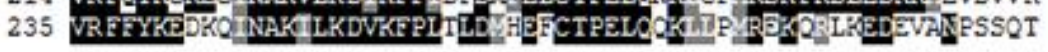

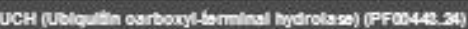

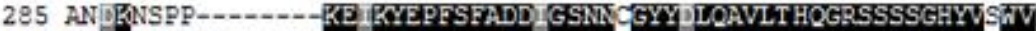

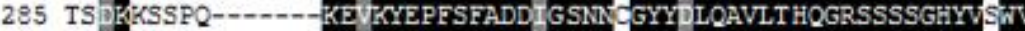
285 EPNGKPGAL-.---.KETKYEPFSAFDD GSNSGYY LOAVLT HQGRSSSSGHYVAWV

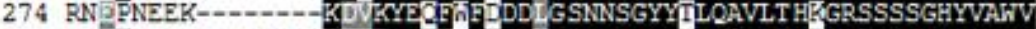

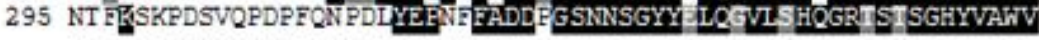

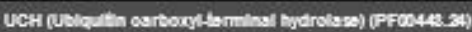

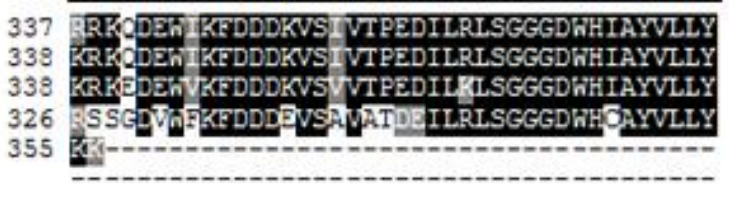

Aminoácidos idênticos

Aminoácidos conservados

Figura 11. Alinhamento da sequência da proteína SmUbp6 (Smp_084740) com sequências ortólogas. As sequências preditas de aminoácidos para cada um dos organismos foram recuperadas através do algoritmo BLASTp no banco de dados do NCBI e alinhadas com a sequência Smp_084740 usando ClustalW. 
Tabela 4. Conservação da proteína Ubp6 nos diferentes organismos

\begin{tabular}{cccc}
\hline Organismo & Número de acesso & Cobertura (\%) & Identidade (\%) \\
\hline & SmUbp6 (Smp_084740) & & \\
Mus musculus & BAA93551.1 & 97 & 41 \\
Drosophila melanogaster & NP_609377. 1 & 98 & 40 \\
Homo sapiens & NP_001032411. & 89 & 44 \\
Schistosoma japonicum & AAX27253.2 & 39 & 84 \\
Danio rerio & NP_956267.1 & 97 & 41 \\
\hline
\end{tabular}

Conforme observado para $\mathrm{SmHul5}$, a análise filogenética revelou uma alta homologia entre as sequências ortólogas para a proteína Ubp6 sendo desta forma Schistosoma mansoni e Schistosoma japonicum agrupados em um mesmo clado (Figura 12).

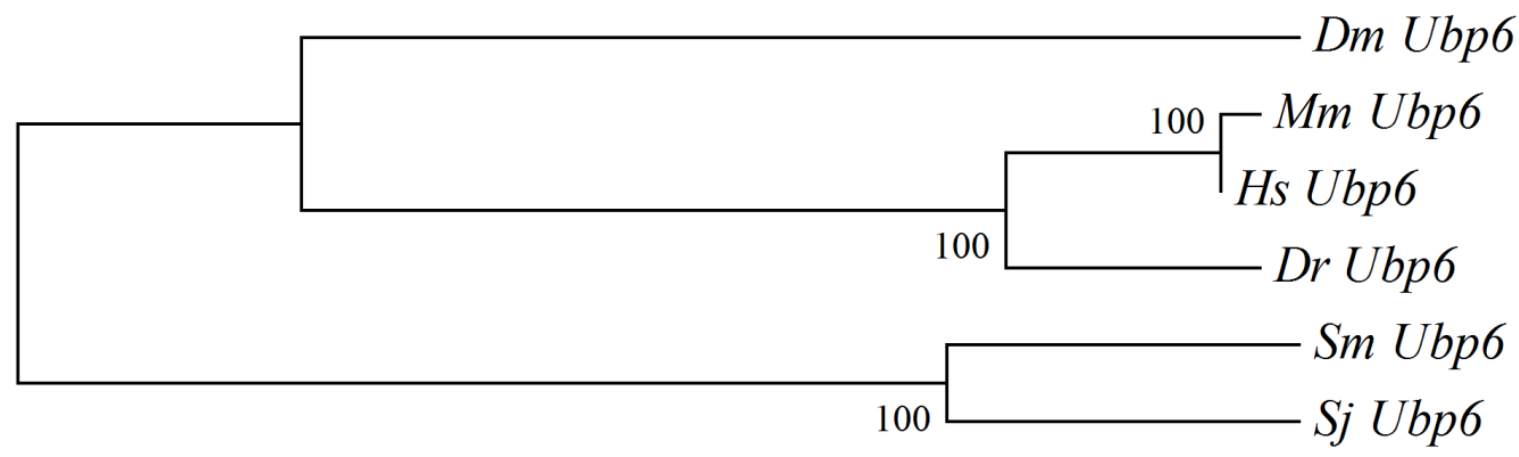

Figura 12. Filogenia entre sequências homólogas à proteína SmUbp6 (Smp_084740). O alinhamento das sequências preditas de aminoácidos da proteína de cada organismo foi realizado utilizando o algoritmo CLUSTALW. Para confecção da árvore filogenética foi utilizado o Método Neighbor-Joining (NJ), sendo utilizado o teste de Boostrap para 1000 replicatas. A porcentagem de árvores replicadas nas quais os taxa foram agrupados juntos é demonstrada na árvore. As posições contendo gaps foram eliminadas do conjunto de dados analisados. As análises filogenéticas foram conduzidas no programa MEGA 4.0. Mm: Mus musculus; Sj: Schistosoma japonicum; Sm: Schistosoma mansoni; Dm: Drosophila melanogaster; Hs: Homo sapiens; Dr: Danio rerio. 
A organização genômica para SmHul5 e SmUbp6 foi obtida através do algoritmo BLAST (bl2seq - NCBI). Para isto a sequência genômica para os respectivos genes foram alinhadas com a sequência do RNA mensageiro, sendo possível desta forma realizar a identificação dos éxons e sua localização relativa no genoma. Como podemos observar na figura 13, o gene SmHul5 apresenta uma região genômica de 57136 nucleotídeos organizados em 23 éxons. A sequência do RNA mensageiro (mRNA) para esse apresenta é constituída por 4971 nucleotídeos a qual codifica uma proteína de 1656 aminoácidos.

DNA genômico

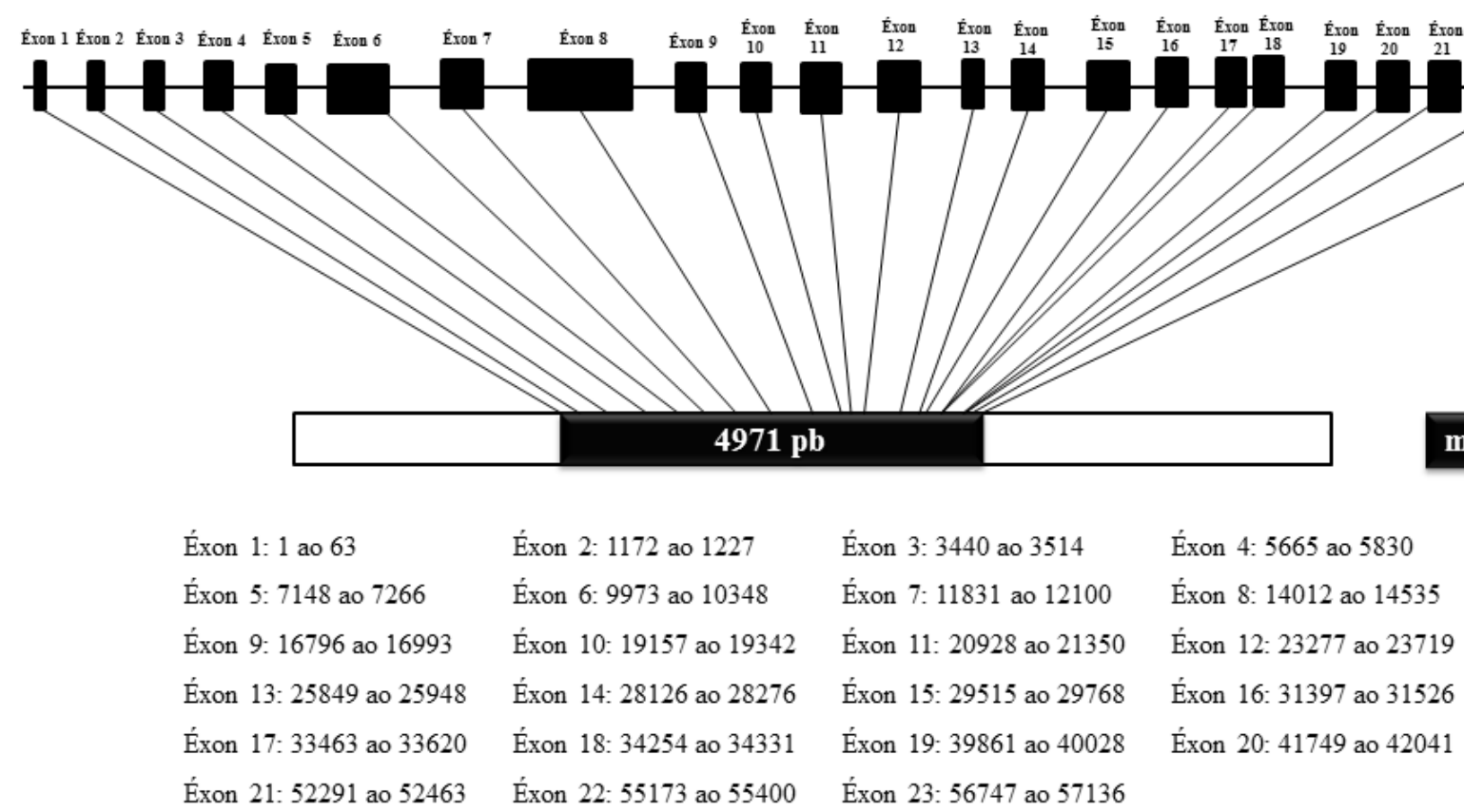

Figura 13. Organização genômica de SmHul5 (Smp_130650). Representação esquemática da estrutura gênica de SmHul5. No esquema é mostrada a região genômica $(57136$ pb), a região codificadora (mRNA - RNA mensageiro) composta por 4971 pb e a localização genômica dos éxons e suas posições relativas. O tamanho dos éxons é representado em pares de bases (pb).

Em relação a $S m U b p 6$, a região genômica é organizada em 6 éxons e composta por 12766 nucleotídeos (figura 14). A sequência completa do RNA mensageiro apresenta 1218 nucleotídeos que codificam uma proteína com 405 aminoácidos. 


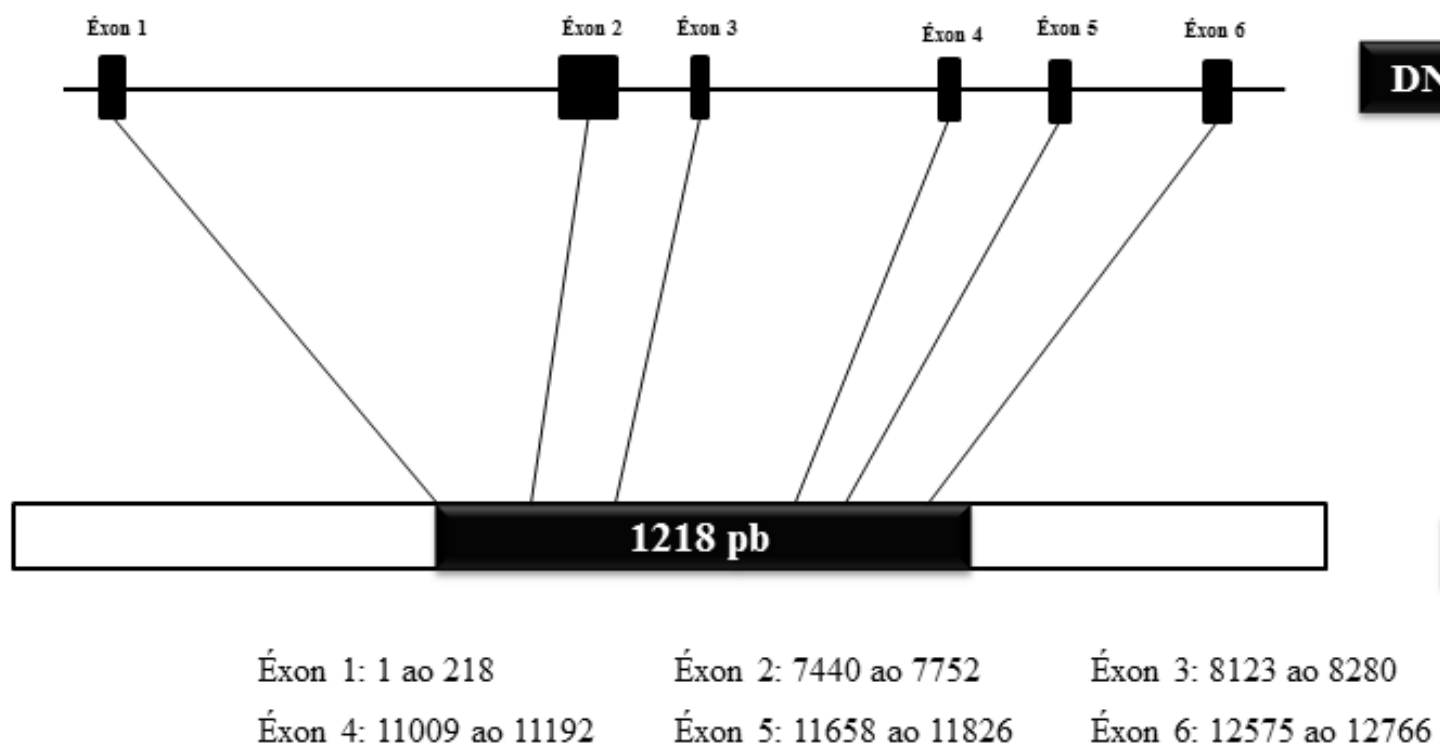

Figura 14. Organização genômica de SmUbp6 (Smp_084740). Representação esquemática da estrutura gênica de SmUbp6. No esquema é mostrada a região genômica (12766 pb), a região codificadora (mRNA - RNA mensageiro) composta por 1218 pb e a localização genômica dos éxons e suas posições relativas. O tamanho dos éxons é representado em pares de bases (pb).

\subsubsection{Validação dos oligonucleotídeos iniciadores por PCR}

Com o objetivo de confirmar se os oligonucleotídeos iniciadores para os genes descritos na tabela 2 (Material e Métodos) permitiam a amplificação dos genes para as proteínas acessórias do proteassoma $S m H u l 5$ e $S m U b p 6$ e para a proteína de maturação do proteassoma $(S m P O M P)$ foram realizadas reações de amplificação para identificação dos transcritos na fase evolutiva de vermes adultos.

A figura 15 mostra os diferentes transcritos obtidos dessas reações de amplificação. Como mostrado, todos os transcritos apresentam o tamanho em pares de bases conforme esperado, demonstrando que os oligonucleotídeos iniciadores foram corretamente desenhados e dirigem a amplificação dos genes em estudos. Para SmHul5 foi observado um fragmento de 148 pb, enquanto que para SmUbp6 os oligonucleotídeos iniciadores dirigiram a síntese de um fragmento de aproximadamente $139 \mathrm{pb}$. 


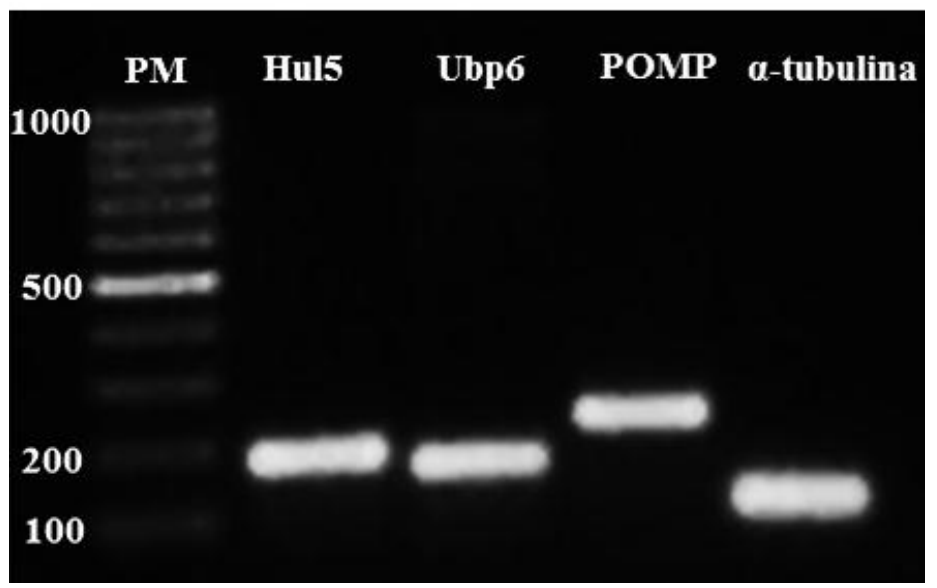

Figura 15. Validação dos oligonucleotídeos iniciadores dos genes referentes a enzimas acessórias ao proteassoma de $\boldsymbol{S}$. mansoni e proteína de maturação do proteassoma. Validação dos genes $\operatorname{SmHul5}$ (148 pb), SmUbp6 (139 pb) e SmPOMP (191 pb). Gel de Agarose 1,5\% corado com GelRed ${ }^{\mathrm{TM}}$. (PM) Peso molecular (100 pb) e $\alpha$-tubulina (controle interno - $70 \mathrm{pb}$ ).

\subsubsection{Perfil de expressão de $S m H u l 5$ e SmUbp6 no ciclo de vida de $S$. mansoni}

A expressão dos genes SmHul5 e SmUpb6 foi analisada nas fases de ovo, miracídio, esporocisto, cercária, esquistossômulos e verme adulto. Para a fase de esquistossômulos vários tempos de cultivo in vitro foram testados esquistossômulo recém-transformado (0h), esquistossômulo 2h, esquistossômulo 4h, esquistossômulo $6 \mathrm{~h}$, esquistossômulo $8 \mathrm{~h}$ e esquistossômulo 18,5h. Anteriormente a análise de expressão através de qPCR, reações de PCR foram realizadas para avaliar se os genes em estudo eram expressos em cada fase específica. Está ensaio inicial permitiu identificar que os genes SmHul5 e SmUbp6 não são expressos na fase de cercária.

Como demonstrado na figura 16 A, o perfil de expressão de $\mathrm{SmHul5}$ varia muito entre as diferentes fases, sendo significativamente diferente de verme adulto nos estágios de esporocisto, esquistossômulo $2 \mathrm{~h}$, esquistossômulo $4 \mathrm{~h}$ e esquistossômulo $6 \mathrm{~h}$. Além disso, foi mostrado que o nível de expressão para o gene $\mathrm{SmHul5}$ é relativamente baixo para as fases de ovo, miracídio, verme adulto e esquistossômulos 0 h, 8 h e 18,5 h (Figura 16 A). A expressão deste gene é alta no estágio de esporocisto e apresenta uma brusca diminuição em esquistossômulos recém-transformados (esquistossômulo 0h). Quando analisamos a expressão deste gene somente no estágio de esquistossômulo, verificamos que sua expressão inicia-se no estádio de esquistossômulo $\mathrm{Oh}$ apresentando um pico de expressão nas fases de esquistossômulo $2 \mathrm{~h}$, esquistossômulo $4 \mathrm{~h}$ e esquistossômulo $6 \mathrm{~h}$, o qual começa a declinar na 
fase de esquistossômulo $8 \mathrm{~h}$ atingindo níveis relativamente baixos e sem diferença significativa em relação a vermes adultos no estádio de esquistossômulos de 18,5 h (Figura 16 A). O alto nível de expressão deste gene para alguns estádios de esquistossômulo e para o estágio de esporocisto sugere que este gene é extremamente importante para o desenvolvimento do parasito nestas duas fases do seu ciclo de vida.

A expressão gênica de SmHul5 foi comparada entre vermes adultos macho e fêmea, e como demonstrado na figura 16 B não existe diferença estatística entre os gêneros, sendo a expressão deste gene maior em vermes adultos pareados.

A

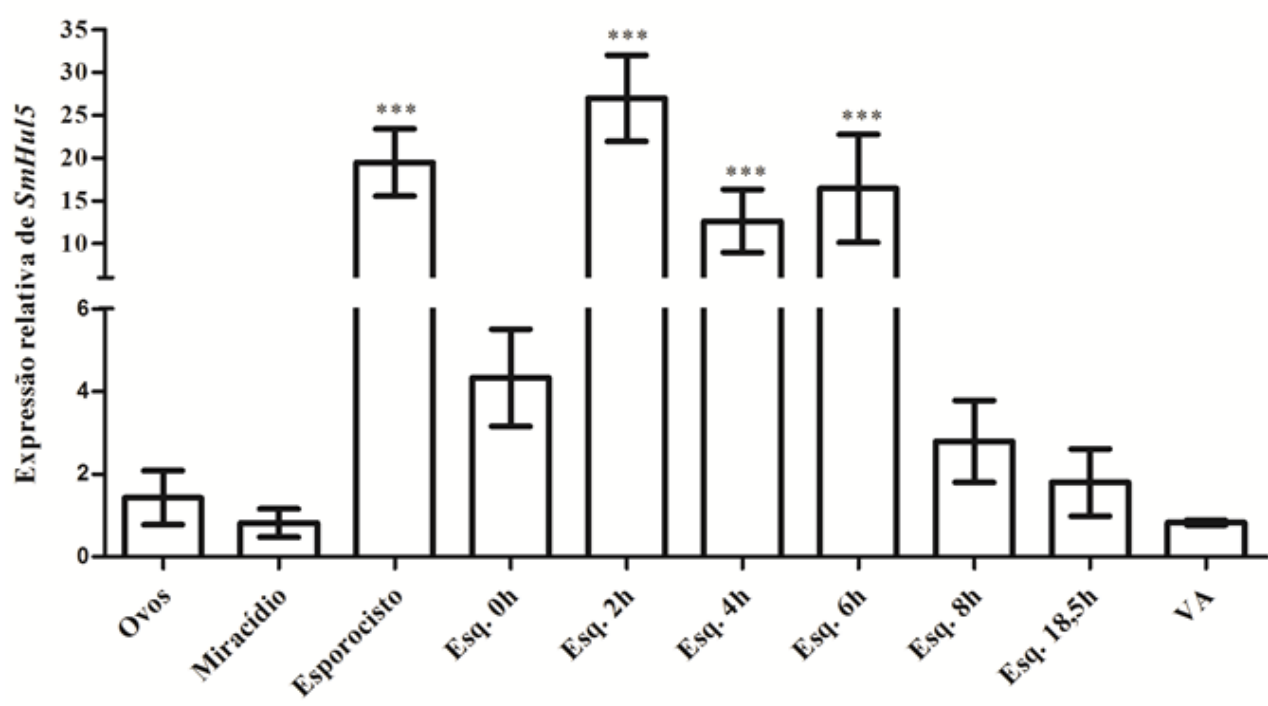

B

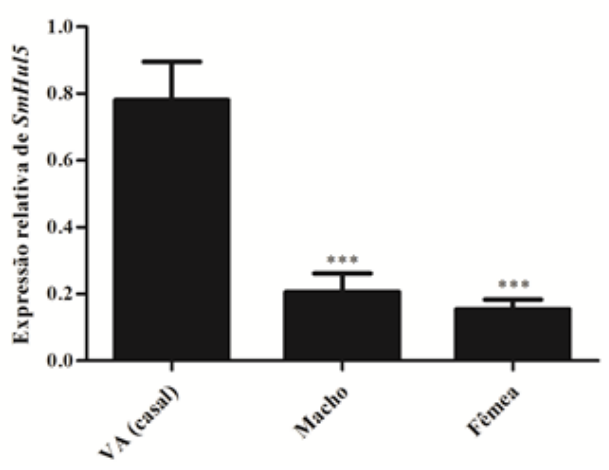

Figura 16. Expressão do gene SmHul5 nas fases evolutivas de $\boldsymbol{S}$. mansoni . (A) Análise de expressão nas fases de verme adulto (VA), ovos, miracídio, esporocisto, esquistossômulos ( 0 h, 2 h, 4 h, 6 h, 8 h, 18,5 h) e (B) Expressão diferencial de $\mathrm{SmHul5}$ em vermes adultos macho e fêmea. *** Diferem de verme adulto através de Teste Tukey $(\mathrm{P}<0,0001)$. O número relativo de transcritos de $S m H u l 5$ foram normalizados em relação ao gene endógeno GAPDH (Gliceraldeído-3 fosfato desidrogenase). Os resultados foram multiplicados por 100 para facilitar a visualização dos mesmos. Os resultados são provenientes de três experimentos independentes, e as reações foram preparadas em triplicata, sendo expressos como média \pm desvio padrão. 
Na figura 17, podemos observar que os níveis de transcritos para SmUbp6 são relativamente baixos para as fases de verme adulto, ovos, esquistossômulo $0 \mathrm{~h}$, esquistossômulo 4 h, esquistossômulo 6 h, esquistossômulo 8 h e esquistossômulo 18,5 h (Figura 17 A). Quando comparados somente os estádios de esquistossômulos, observa-se que o nível de expressão de SmUbp6 é estatisticamente diferente de vermes adultos em esquistossômulo 2h (Figura 17 A). Além disso, foi encontrado um nível de expressão relativamente alto para este gene nas fases de miracídio, esporocisto e esquistossômulo $2 \mathrm{~h}$, sugerindo deste modo, que este gene seja importante para o desenvolvimento do parasito nestas três fases evolutivas. Uma redução significativa na expressão deste gene é observada na transição das fases de miracídios para esporocistos (Figura 17 A).

Interessantemente, o nível de expressão de SmUbp6 em vermes adultos machos foi estatisticamente diferente de vermes adultos pareados e fêmeas, sugerindo que este gene é importante para o desenvolvimento de vermes adultos machos (Figura 17 B). O perfil de expressão de $S m U b p 6$, assim com para $S m H u l 5$, vai diminuindo ao longo do desenvolvimento dos esquistossômulos até atingir níveis similares a vermes adultos. 


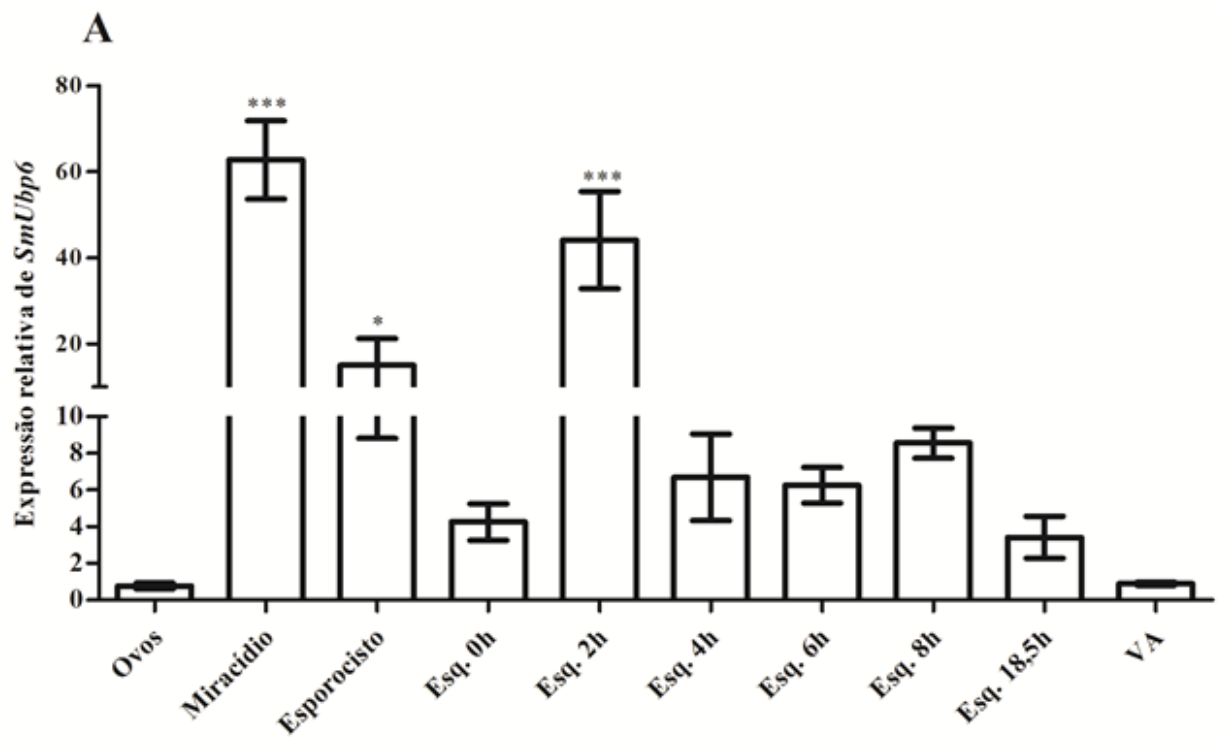

B

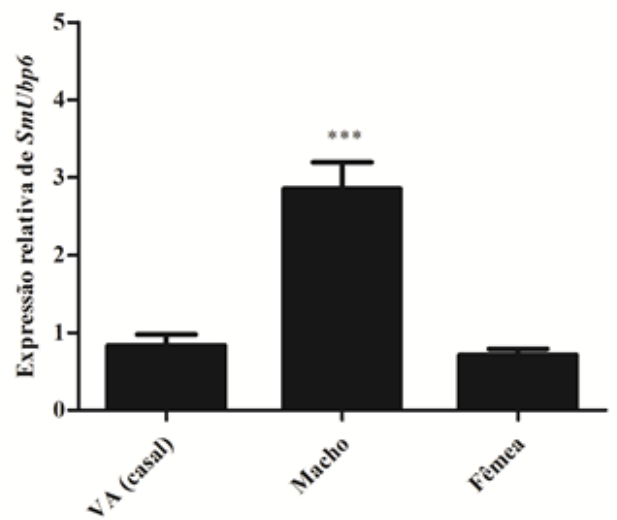

Figura 17. Expressão do gene SmUbp6 nas fases evolutivas de $\boldsymbol{S}$. mansoni . (A) Análise de expressão nas fases de verme adulto (VA), ovos, miracídio, esporocisto e esquistossômulos ( 0 h, 2 h, 4 h, 6 h, 8 h, 18,5 h), (B) Expressão diferencial de SmUbp6 em vermes adultos macho e fêmea. *** Diferem de verme adulto através de Teste Tukey $(\mathrm{P}<0,0001)$, * Difere de verme adulto através de Teste Tukey $(\mathrm{P}<0,05)$. O número relativo de transcritos de SmUbp6 foram normalizados em relação ao gene endógeno GAPDH (Gliceraldeído-3 fosfato desidrogenase). Os resultados foram multiplicados por 100 para facilitar a visualização dos mesmos. Os resultados são provenientes de três experimentos independentes, e as reações foram preparadas em triplicata, sendo expressos como média \pm desvio padrão.

\subsection{Caracterização do estresse oxidativo}

\subsubsection{Resposta in vitro ao estresse oxidativo}

A resposta in vitro dos vermes adultos de $S$. mansoni ao estresse oxidativo foi medida analisando os parâmetros de pareamento dos casais, mortalidade, alteração na atividade 
motora, alterações no tegumento, viabilidade e produção de ovos. A cada 24 h de cultivo, os vermes foram monitorados em microscópio de luz invertida e as alterações analisadas.

A tabela 5 apresenta as alterações de vermes adultos de $S$. mansoni em reposta ao estresse oxidativo. Como podemos observar, nas concentrações de $100 \mu \mathrm{M}, 200 \mu \mathrm{M}, 300 \mu \mathrm{M}$ e $400 \mu \mathrm{M}$ não ocorreram mudanças aparentes quanto ao pareamento, mortalidade e alterações no tegumento dos vermes adultos. Na concentração de $400 \mu \mathrm{M}$ foi possível observar uma redução na atividade motora de $100 \%$ dos vermes analisados, no entanto, esta redução foi não significativa. Para estas concentrações os efeitos foram semelhantes e independentes do tempo de cultivo (24 h ou $120 \mathrm{~h}$ ).

As alterações decorrentes de resposta ao estresse oxidativo foram mais evidentes nas concentrações a partir de $500 \mu \mathrm{M}$ de peróxido de hidrogênio. Para a concentração de $500 \mu \mathrm{M}$, podemos observar já em 24 h de cultivo a separação de $75 \%$ dos casais de vermes, sendo este valor igual a 100\% após 120 h. Além disso, foi possível identificar uma redução significativa na motilidade dos vermes, sendo esta redução mais aparente para os vermes adultos machos. Na concentração de $800 \mu \mathrm{M}$ foi possível identificar $100 \%$ de separação dos casais de vermes já a partir de 24 h de cultivo in vitro e 100\% de mortalidade dos casais após 120 h. Para esta concentração foi observada significativa redução na atividade motora dos vermes bem como formação de pequenas vesículas no tegumento.

Nas concentrações a partir de $1 \mathrm{mM}$ de peróxido de hidrogênio foi possível identificar $100 \%$ de mortalidade e significativa redução na atividade motora dos vermes adultos nas primeiras 24 h de cultivo in vitro. Na concentração de $1 \mathrm{mM}$ foi possível identificar $100 \%$ de separação de casais após 24 h de cultivo e também a formação de vesículas no tegumento. Já nas concentrações de $2 \mathrm{mM}, 3 \mathrm{mM}, 4 \mathrm{mM}$ e $5 \mathrm{mM}$ não foi possível identificar a separação dos casais, estes apresentam 100\% de mortalidade e apresentaram aspecto de concha (vermes mortos não separados - resultado semelhante ao tratamento com Praziquantel). Nessas concentrações, os vermes morreram logo nas primeiras horas de cultivo in vitro. 
Tabela 5. Efeito in vitro do estresse oxidativo com peróxido de hidrogênio em vermes adultos de $S$. mansoni

\begin{tabular}{|c|c|c|c|c|c|c|c|}
\hline \multirow{2}{*}{ Concentração } & \multirow{2}{*}{$\begin{array}{c}\text { Período } \\
\text { Incubação (h) }\end{array}$} & \multirow{2}{*}{$\begin{array}{c}\text { Casais } \\
\text { Separados }(\%)\end{array}$} & \multirow{2}{*}{$\begin{array}{c}\text { Vermes } \\
\text { Mortos } \\
(\%)\end{array}$} & \multicolumn{2}{|c|}{$\begin{array}{c}\text { Redução na } \\
\text { Atividade motora }(\%)\end{array}$} & \multicolumn{2}{|c|}{ Alterações no tegumento (\%) } \\
\hline & & & & $\begin{array}{c}\text { Não } \\
\text { significativo }\end{array}$ & Significativo & Parcial & Extensiva \\
\hline \multirow{2}{*}{ Controle } & $24 \mathrm{~h}$ & 0 & 0 & - & - & - & - \\
\hline & $120 \mathrm{~h}$ & 0 & 0 & - & - & - & - \\
\hline \multicolumn{8}{|c|}{ Peróxido de hidrogênio } \\
\hline \multirow{2}{*}{$100 \mu \mathrm{M}$} & $24 \mathrm{~h}$ & 0 & 0 & - & - & - & - \\
\hline & $120 \mathrm{~h}$ & 0 & 0 & - & - & - & - \\
\hline \multirow{2}{*}{$200 \mu \mathrm{M}$} & $24 \mathrm{~h}$ & 0 & 0 & - & - & - & - \\
\hline & $120 \mathrm{~h}$ & 0 & 0 & - & - & - & - \\
\hline \multirow{2}{*}{$300 \mu \mathrm{M}$} & $24 \mathrm{~h}$ & 0 & 0 & - & - & - & - \\
\hline & $120 \mathrm{~h}$ & 0 & 0 & - & - & - & - \\
\hline \multirow{2}{*}{$400 \mu \mathrm{M}$} & $24 \mathrm{~h}$ & 0 & 0 & - & - & - & - \\
\hline & $120 \mathrm{~h}$ & 25 & 0 & 100 & - & - & - \\
\hline \multirow{2}{*}{$500 \mu \mathrm{M}$} & $24 \mathrm{~h}$ & 75 & 0 & - & 100 & - & - \\
\hline & $120 \mathrm{~h}$ & 100 & 0 & - & 100 & - & - \\
\hline \multirow{2}{*}{$800 \mu \mathrm{M}$} & $24 \mathrm{~h}$ & 100 & 0 & - & 100 & - & 100 \\
\hline & $120 \mathrm{~h}$ & 100 & 100 & - & 100 & - & 100 \\
\hline
\end{tabular}




\begin{tabular}{|c|c|c|c|c|c|c|c|}
\hline \multirow{2}{*}{ Concentração } & \multirow{2}{*}{$\begin{array}{c}\text { Período } \\
\text { Incubação (h) }\end{array}$} & \multirow{2}{*}{$\begin{array}{c}\text { Casais } \\
\text { Separados } \\
(\%)\end{array}$} & \multirow{2}{*}{$\begin{array}{c}\text { Vermes } \\
\text { Mortos } \\
\%\end{array}$} & \multicolumn{2}{|c|}{$\begin{array}{c}\text { Redução na } \\
\text { Atividade motora }(\%)\end{array}$} & \multicolumn{2}{|c|}{ Alterações no tegumento (\%) } \\
\hline & & & & $\begin{array}{c}\text { Não } \\
\text { significativo }\end{array}$ & Significativo & Parcial & Extensiva \\
\hline \multicolumn{8}{|c|}{ Peróxido de hidrogênio } \\
\hline $1 \mathrm{mM}$ & $24 \mathrm{~h}$ & 100 & 100 & - & 100 & - & 100 \\
\hline \multirow{2}{*}{$2 \mathrm{mM}$} & $24 \mathrm{~h}$ & 0 & 100 & - & 100 & & n.a \\
\hline & $120 \mathrm{~h}$ & 0 & 100 & - & 100 & & n.a \\
\hline \multirow{2}{*}{$3 \mathrm{mM}$} & $24 \mathrm{~h}$ & 0 & 100 & - & 100 & & n.a \\
\hline & $120 \mathrm{~h}$ & 0 & 100 & - & 100 & & n.a \\
\hline $5 \mathrm{mM}$ & $120 \mathrm{~h}$ & 0 & 100 & - & 100 & & n.a \\
\hline
\end{tabular}

*Os resultados são provenientes de três experimentos independentes, sendo: (\%) Porcentagens referentes a 12 casais de vermes adultos analisados. n.a: Alterações do tegumento não avaliadas devido à morte dos vermes. 
Para avaliar o efeito de reversibilidade do tratamento de estresse oxidativo, após 120 h de cultivo in vitro, os vermes tratados com concentrações de peróxido de hidrogênio que provocaram apenas separação dos casais e alterações na motilidade foram plaqueados em placas de cultura estéril contendo meio de cultivo (RPMI suplementado) sem peróxido de hidrogênio e foram então mantidos em cultura por mais $48 \mathrm{~h}$. Após monitoramento em microscópio de luz invertida, foi possível observar a não reversibilidade dos efeitos oriundos do estresse oxidativo (dados não mostrados).

\subsubsection{Viabilidade de vermes adultos}

A viabilidade de vermes adultos pareados submetidos a estresse oxidativo com concentrações crescentes de peróxido de hidrogênio foi analisada através do ensaio de MTT. Os resultados são apresentados na figura 18, e como podemos observar, houve diferença significativa na viabilidade de vermes adultos de $S$. mansoni tratados com concentrações a partir de $400 \mu \mathrm{M}$ de peróxido de hidrogênio quando comparados com o tratamento controle negativo (vermes mantidos em meio RPMI). Além disso, quando os valores são comparados com o controle positivo (vermes mortos a $56^{\circ} \mathrm{C}$ ) podemos perceber que todos os valores a partir de $100 \mu \mathrm{M}$ de peróxido de hidrogênio são estatisticamente diferentes deste tratamento. A viabilidade dos vermes submetidos à estresse oxidativo com as concentrações de 100, 200 e $300 \mu \mathrm{M}$ de peróxido de hidrogênio não diferem em relação ao controle negativo.

Diante destes resultados, foi escolhida a concentração de $200 \mu \mathrm{M}$ para os experimentos posteriores (análise de expressão gênica e proteoma), uma vez que é uma concentração intermediária em relação às outras duas $(100 \mu \mathrm{M}$ e $300 \mu \mathrm{M})$, e foi capaz de induzir estresse oxidativo de forma significativa sem, no entanto, causar mudanças na viabilidade dos casais de vermes. 


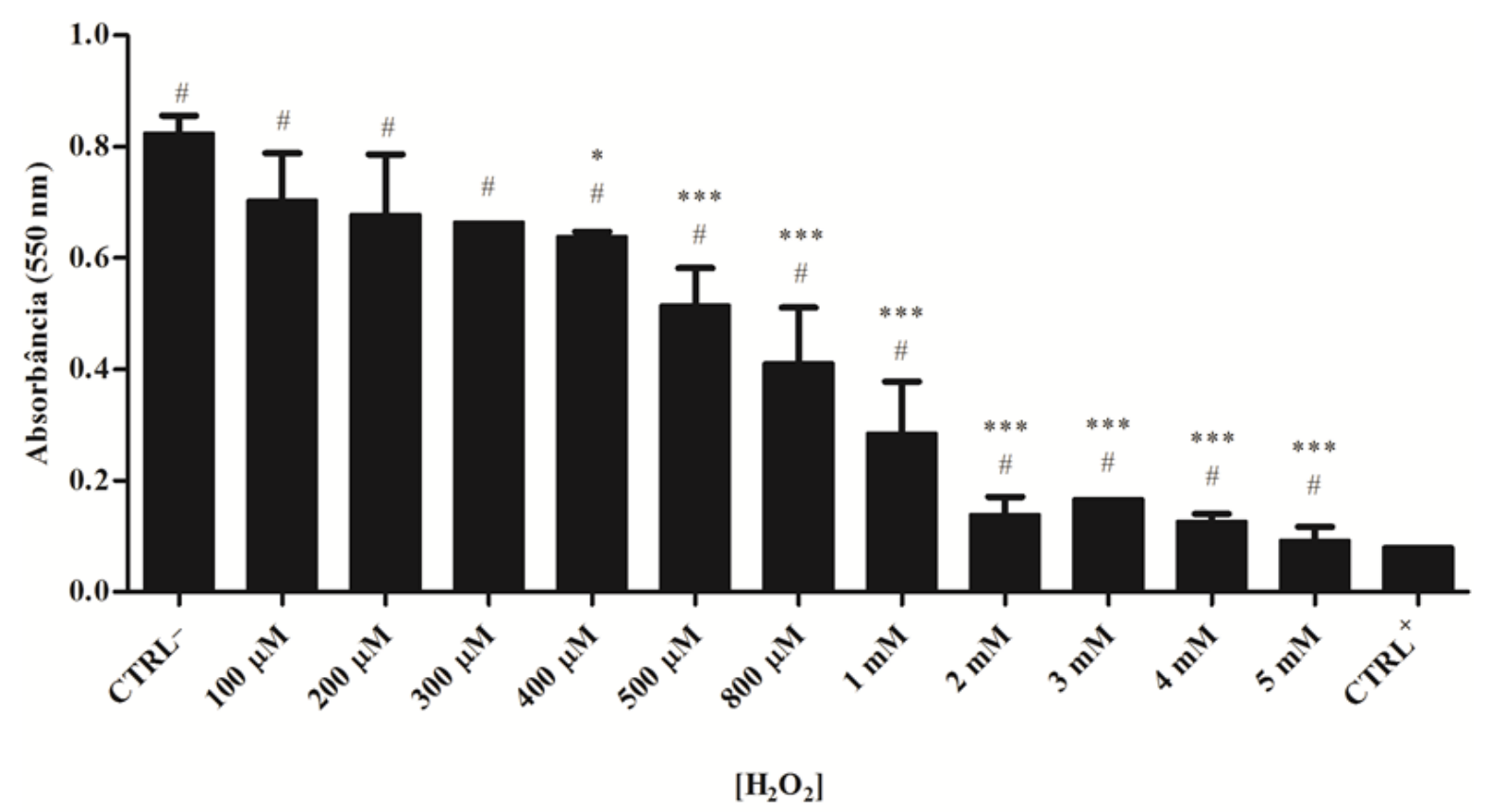

Figura 18. Efeito in vitro de estresse oxidativo com peróxido de hidrogênio na viabilidade de vermes adultos de S.mansoni. Viabilidade inferida através do ensaio de MTT 24 h após de estresse oxidativo. Vermes adultos sem tratamento foram utilizados como controle negativo e vermes adultos mortos pelo calor a $56^{\circ} \mathrm{C}$ por 15 minutos como controle positivo. *** Diferem do controle negativo (vermes não tratados) através de teste Tukey $(\mathrm{P}<0,0001)$, * Diferem do controle negativo $(\mathrm{P}<0,05)$ e \# Diferem do controle positivo $(\mathrm{P}<0,05)$. Os dados são representativos de três experimentos independentes, e as reações foram preparadas em quadruplicata, sendo os valores expressos como média \pm desvio padrão.

Para determinar se o tempo de tratamento não afetaria de maneira significativa a viabilidade de vermes adultos, foi realizado um experimento no qual os vermes foram tratados com $200 \mu \mathrm{M}$ de peróxido de hidrogênio por 24 h, 48 h, 72 h, 96 h e 120h. Como podemos observar na figura 19, não houve diferença significativa na viabilidade dos vermes adultos quanto ao tempo de cultivo in vitro, sendo desta forma escolhido o tempo de $24 \mathrm{~h}$ de cultivo para os experimentos posteriores. 


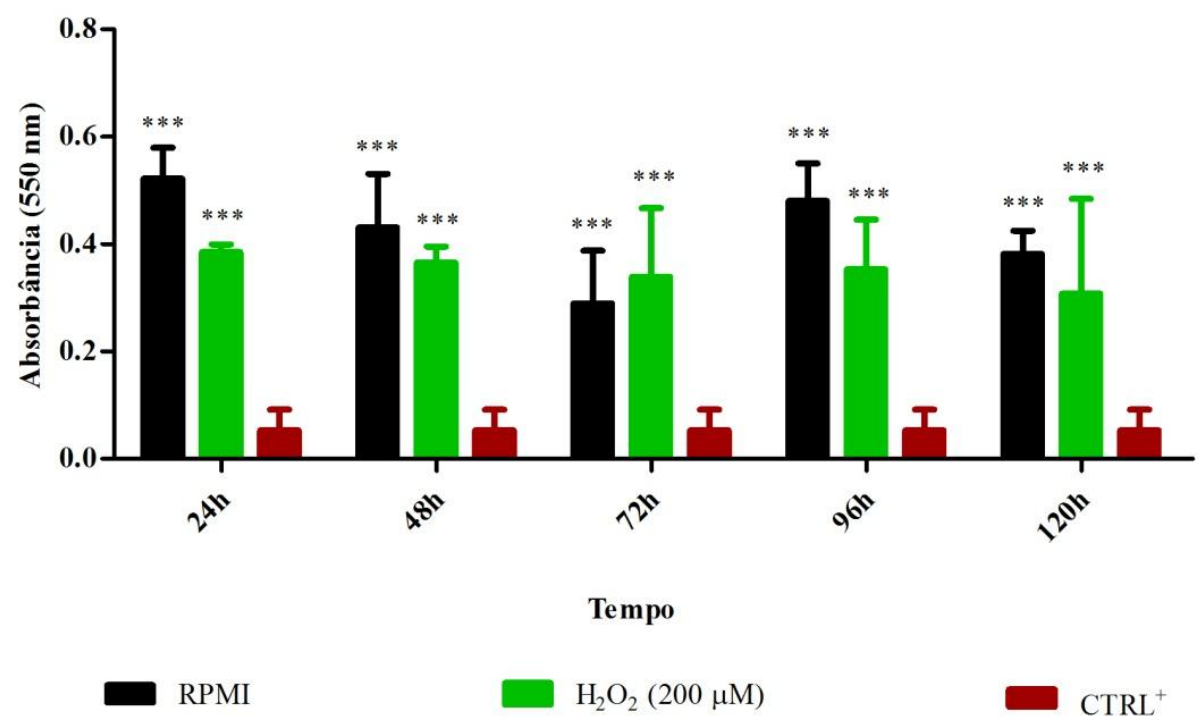

Figura 19. Efeito do tempo na viabilidade de vermes adultos de $S$. mansoni submetidos a estresse oxidativo. Viabilidade inferida através do ensaio de MTT 24 h, 48h, 72 h, 96 h e 120 h após de estresse oxidativo. Vermes adultos sem tratamento foram utilizados como controle negativo e vermes adultos mortos pelo calor a $56^{\circ} \mathrm{C}$ por 15 minutos como controle positivo. *** Diferem do controle positivo através de teste Tukey $(\mathrm{P}<0,0001)$. Os dados são representativos de três experimentos independentes, e as reações foram preparadas em quadruplicata, sendo os valores expressos como média \pm desvio padrão.

\subsubsection{Produção de ovos}

Para avaliar os efeitos do estresse oxidativo na ovoposição, casais de vermes adultos foram incubados durante $120 \mathrm{~h}$ com concentrações de peróxido de hidrogênio que variaram de $100 \mu \mathrm{M}$ a $5 \mathrm{mM}$. Para isto, os casais de vermes mantidos no cultivo in vitro foram monitorados a cada $24 \mathrm{~h}$, sendo a produção total de ovos determinada após $120 \mathrm{~h}$ de cultivo.

Como demonstrado na figura 20, houve uma redução significativa na produção de ovos nas concentrações a partir de $300 \mu \mathrm{M}$ de peróxido de hidrogênio. A diminuição na ovoposição pode ter sido provocada principalmente pela alta porcentagem de separação dos casais de vermes adultos nas concentrações acima de $400 \mu \mathrm{M}$ de peróxido de hidrogênio. A viabilidade de vermes adultos de $S$. mansoni tratados com $300 \mu \mathrm{M}$ de peróxido de hidrogênio não diminui em relação ao controle negativo após 24 horas de cultivo in vitro. No entanto, a diminuição ovoposição observada, nesta concentração, pode estar relacionada com uma diminuição na viabilidade dos casais de vermes após 120 horas, efeito este não analisado em nosso trabalho. Nas concentrações acima de $800 \mu \mathrm{M}$ a diminuição na ovoposição pode ser explicada pela mortalidade dos vermes adultos. Para as concentrações de $100 \mu \mathrm{M}$ e $200 \mu \mathrm{M}$ não houve diferença significativa na produção de ovos em comparação com o tratamento controle (vermes adultos mantidos em meio RPMI). 


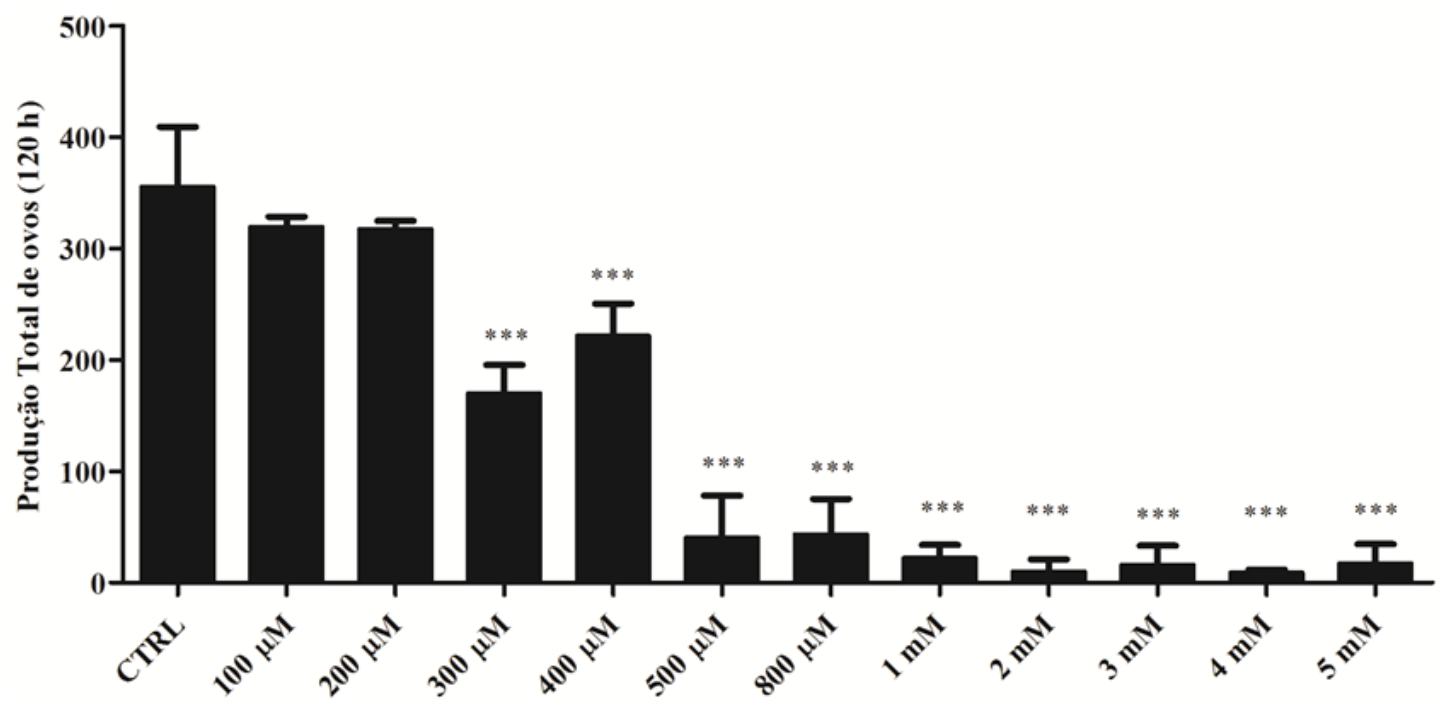

$\left[\mathrm{H}_{2} \mathrm{O}_{2}\right]$

Figura 20. Produção de ovos de vermes adultos de $S$. mansoni submetidos a estresse oxidativo. Após indução de estresse oxidativo os vermes adultos foram monitorados a cada $24 \mathrm{~h}$, sendo a produção total de ovos determinada após $120 \mathrm{~h}$ de cultivo in vitro. *** Diferem do controle (vermes não tratados) através de teste Tukey $(\mathrm{P}<0,0001)$. Os dados são representativos de três experimentos independentes, sendo os valores expressos como média \pm desvio padrão.

\subsubsection{Microscopia eletrônica de varredura para avaliação de danos no} tegumento de vermes adultos de $\mathrm{S}$. mansoni oriundos de estresse oxidativo

Como demonstrado na tabela 5, nas menores concentrações de peróxido de hidrogênio (100-500 $\mu \mathrm{M})$, não ocorreram mudanças significativas na morfologia do tegumento de vermes adultos submetidos a este tipo de estresse. No entanto, a partir da concentração de $800 \mu \mathrm{M}$, os danos no tegumento foram mais evidentes. Desta forma para analisar estes danos provocados por altas concentrações de peróxido de hidrogênio, a morfologia do tegumento foi analisada através de microscopia eletrônica de varredura em vermes tratados com as concentrações de $800 \mu \mathrm{M}$ e $1 \mathrm{mM}$, nas quais tais os danos foram mais evidentes. A concentração de $800 \mu \mathrm{M}$ foi escolhida como concentração inicial, pois nesta concentração podemos observar uma diminuição de 50\% na viabilidade dos vermes adultos.

$\mathrm{Na}$ figura 21 A está representado a morfologia do tegumento de vermes adultos controle (mantidos em meio RPMI). Como podemos observar, existe a presença de uma grande quantidade de tubérculos com espinhos ( $21 \mathrm{~B}$ e C) no tegumento de vermes adultos 
de S. mansoni. Além disso, na figura $21 \mathrm{D}$ podemos observar a morfologia normal da ventosa ventral.

$\mathrm{Na}$ figura 22 são mostradas as microscopias de vermes oriundos do tratamento com $10 \mu \mathrm{M}$ de Praziquantel (controle positivo) por um período de $24 \mathrm{~h}$. Como podemos observar ocorreram intensas mudanças na morfologia do tegumento dos vermes oriundos deste tratamento. Primeiramente, podemos observar uma ampla diminuição no número de tubérculos no tegumento (22 A e B) bem como o aparecimento de bolhas entre os tubérculos e a descamação do tegumento (22 B). Além da diminuição do número de tubérculos, podemos também identificar uma diminuição no número de espinhos nos tubérculos $(22 \mathrm{C})$. Outra alteração marcante na morfologia do tegumento de vermes adultos tratados com Praziquantel foi o aparecimento de buracos no tegumento como demonstrado em (22 C, D e E), sendo estes buracos oriundos do rompimento das bolhas formadas entre os tubérculos. Foi possível observar também o enrugamento do tegumento dos vermes (22 C). Além disso, podemos observar a formação de bolhas, descamação e enrugamento na região da ventosa ventral (22 F e G).

Os efeitos causados pelo tratamento de vermes adultos de $S$. mansoni são também evidentes em fêmeas. Estas apresentam uma morfologia do tegumento marcadamente diferente em relação aos machos. Pode-se perceber a completa ausência de tubérculos dando ao tegumento um aspecto liso (Figura 23 A-D). Quando tratadas com $10 \mu \mathrm{M}$ Praziquantel por 24 horas, podemos notar assim como nos machos, a formação de bolhas, o enrugamento, descamação e a formação de buracos no tegumento (Figura 23 E-H). No entanto, uma característica diferente em relação aos machos é a ausência de espinhos no tegumento de fêmeas tratadas com Praziquantel, característica esta determinada pelo acentuado enrugamento do tegumento das fêmeas.

Os vermes adultos de S. mansoni também tiveram sua morfologia do tegumento analisada após tratamento com duas concentrações de peróxido de hidrogênio (estresse oxidativo). Os resultados deste experimento estão representados nas figuras 24 e 25 . As alterações causadas pelo tratamento com $800 \mu \mathrm{M}$ de $\mathrm{H}_{2} \mathrm{O}_{2}$ são semelhantes às alterações provocadas com o tratamento com Praziquantel. Podemos observar extensa descamação (p) e formação de bolhas (b) entre os tubérculos (figura 24 A e B). Em um aumento maior é possível observar a diminuição de espinhos nos tubérculos (sp) bem como um inchaço (s) em alguns tubérculos (figura $24 \mathrm{C}$ e D). Outra característica marcante é a emergência de bolhas a partir dos tubérculos, o que provoca descamação e diminuição de espinhos nos tubérculos (figura $24 \mathrm{D}$ e E). Nas figuras $24 \mathrm{~F}, \mathrm{G}$ e $\mathrm{H}$ podemos observar as principais 
alterações que ocorrem no tegumento de vermes adultos fêmeas quando tratados com 800 $\mu \mathrm{M}$ de $\mathrm{H}_{2} \mathrm{O}_{2}$. Como mostrado nas imagens, ocorre extensa descamação (p) e a formação de pequenas erupções (o) no tegumento. Estas erupções posteriormente rompem-se ocasionando descamação (p) e buracos (h) no tegumento.

O tratamento dos vermes com $1 \mathrm{mM}$ de peróxido de hidrogênio provocou alterações principalmente na região da ventosa ventral. Como é mostrado na figura $25 \mathrm{~A}, \mathrm{~B}, \mathrm{C}$ e D ocorrem extensa descamação e formação de bolhas nesta região.
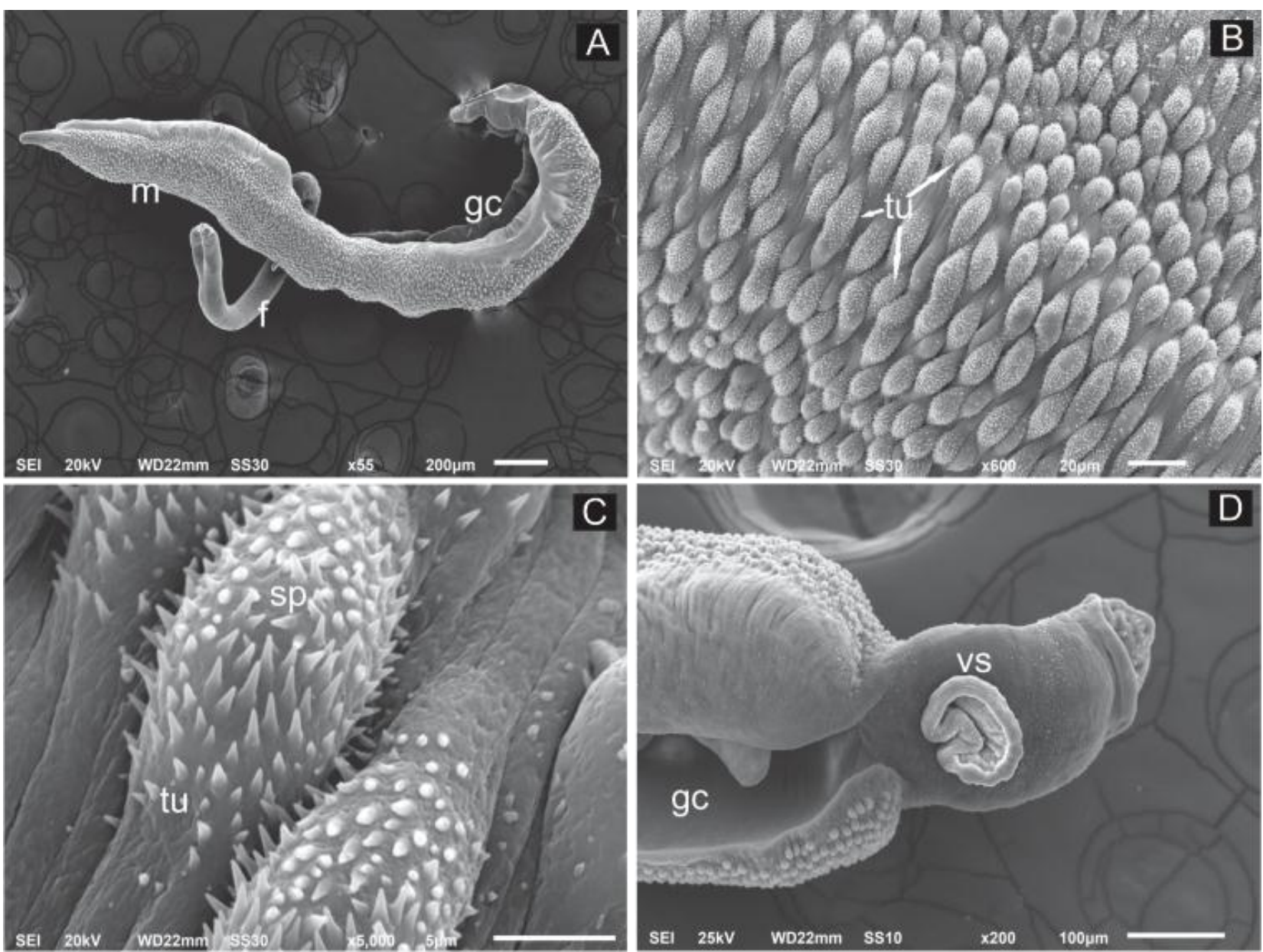

Figura 21. Microscopia eletrônica de varredura do tegumento de vermes adultos de $S$. mansoni. (A, 55x) Vermes adultos com morfologia do tegumento normal (m: machos; f: fêmeas; gc: canal ginecóforo). (B, 600x) Morfologia normal do tegumento de $S$. mansoni evidenciando o grande de número de tubérculos (tu). (C, 5000x) Magnificação de um tubérculo para demonstrar a presença de espinhos (sp). (D, 200x) Morfologia normal da ventosa ventral (vs) de vermes machos de S. mansoni. 

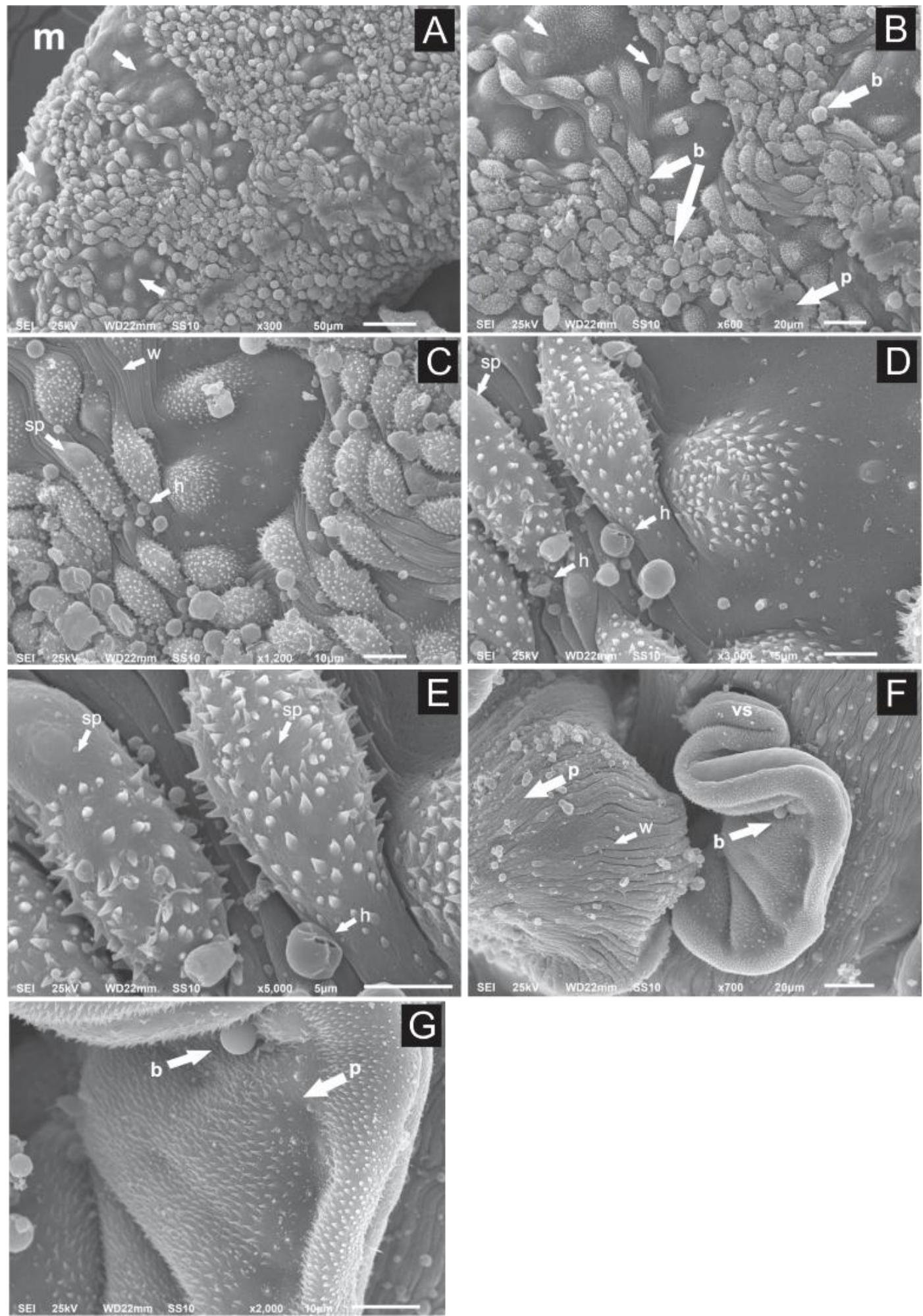

Figura 22. Microscopia eletrônica de varredura do tegumento de vermes adultos machos de $S$. mansoni tratados com $10 \mu \mathrm{M}$ de Praziquantel por 24 horas. (A, 300x) Morfologia do tegumento de vermes adultos alterada (setas: diminuição da quantidade de tubérculos no tegumento; m: machos). (B, 600x) Aparecimento de bolhas e descamação no tegumento de S. mansoni (b: bolhas; p: peeling (descamação). (C, 1200x) Diminuição do número de espinhos nos tubérculos (sp: espinhos); Enrugamento do tegumento (w); e rompimento de bolhas com aparecimento de buracos no tegumento (h).(D, 3000x; E, 5000x) Magnificação para melhor visualização do rompimento das bolhas e a formação de buracos no tegumento (h); (F, 700x; G, 2000) Enrugamento (w), descamação (p) e formação de bolhas (b) na região da ventosa ventral (vv). 

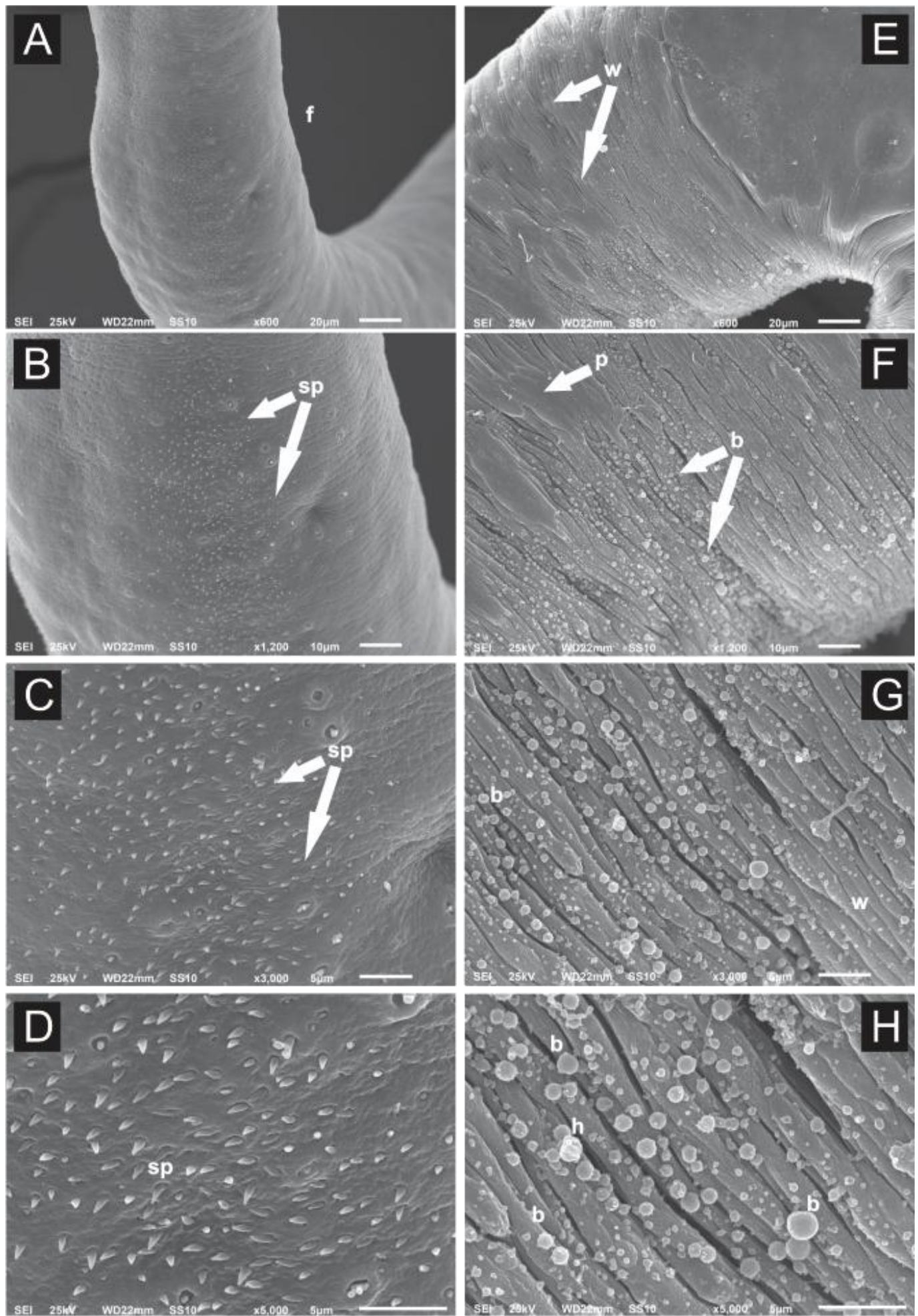

Figura 23. Microscopia eletrônica de varredura do tegumento de vermes adultos fêmeas de $S$. mansoni tratados com $10 \mu \mathrm{M}$ de Praziquantel por 24 horas. (A-D) Morfologia do tegumento de vermes adultos fêmeas controle. (A, 600x; B, 1200x; C, 3000x; D, 5000x) Demonstrando a morfologia do tegumento normal para fêmeas de vermes adultos de $S$. mansoni (f: fêmea; sp: espinhos). (E-H) Vermes adultos fêmeas tratados. (E, 600x; F, 1200x; G, 3000x; H, 5000x) Formação de bolhas, descamação e enrugamento do tegumento, ruptura das bolhas e completa ausência de espinhos no tegumento. 

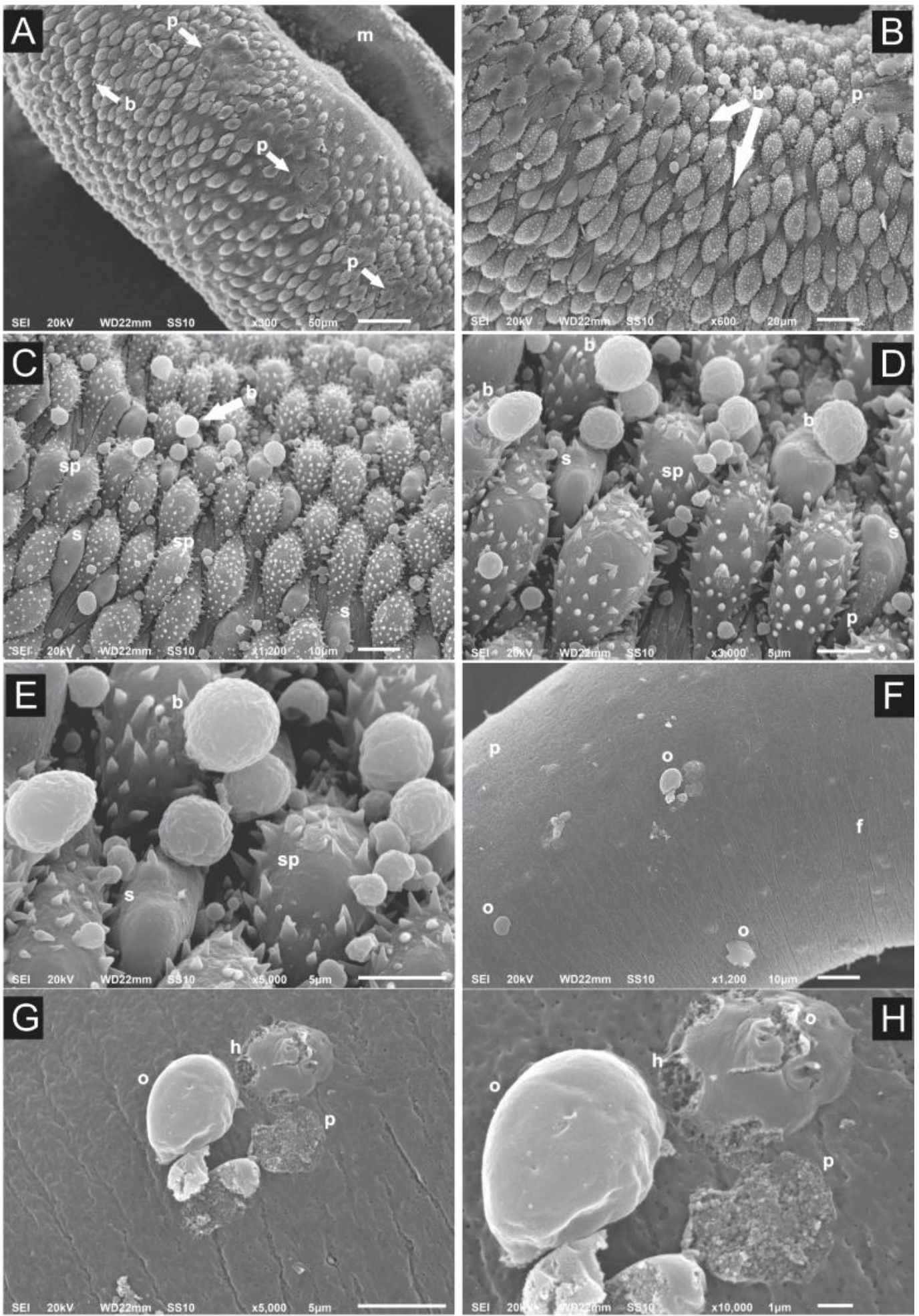

Figura 24. Microscopia eletrônica de varredura do tegumento de vermes adultos de $S$. mansoni tratados com $800 \mu M$ de peróxido de hidrogênio $\left(\mathrm{H}_{2} \mathrm{O}_{2}\right)$ por 24 horas. (A-E) Morfologia do tegumento de vermes adultos machos. (A, 300x; B, 600x; C, 1200x; D, 3000x; E, 5000x) Demonstração das principais alterações na morfologia no tegumento: (m: macho) (A, B) Em diferentes aumentos demonstram descamação (peeling) e formação de bolhas no tegumento. (C, D, E) Magnificação para mostrar bolhas formadas a partir dos tubérculos (b), diminuição de espinhos nos tubérculos (sp), descamação e inchaço (s). (F-H) Vermes adultos fêmeas tratados. (F, 1200x; G, 5000x; H, 10000x) Descamação (p) e formação de erupções (o) que posteriormente rompem-se formando buracos no tegumento (h). 

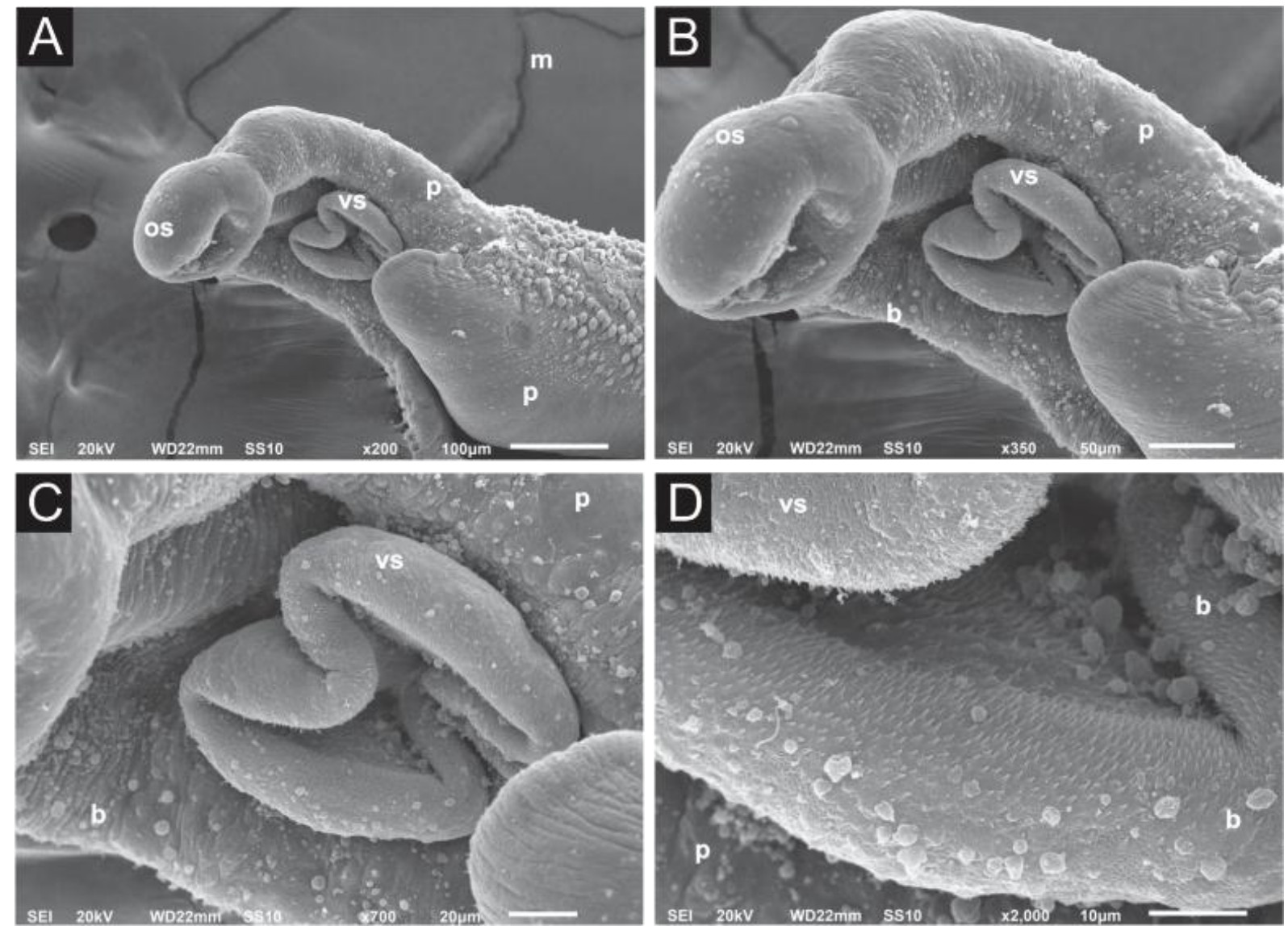

Figura 25. Microscopia eletrônica de varredura do tegumento de vermes adultos de $S$. mansoni tratados com $1 \mathrm{mM}$ de peróxido de hidrogênio $\left(\mathrm{H}_{2} \mathrm{O}_{2}\right)$ por 24 horas. (A-D) Morfologia do tegumento de vermes adultos machos. (A, 200x; B, 350x; C, 700x; D, 2000x) Demonstrando as principais alterações na morfologia no tegumento e na ventosa ventral. m: machos; os: ventosa oral; vs: ventosa ventral; p: descamação; b: bolhas.

\subsubsection{Perfil de expressão de SmHul5 e SmUbp6 no estresse oxidativo}

O estresse oxidativo com $200 \mu \mathrm{M}$ de peróxido de hidrogênio provocou um aumento na expressão dos genes SmHul5 e SmUbp6. Conforme mostrado na figura 26 A, a expressão de SmHul5 apresenta um aumento de 4 vezes após 30 minutos de tratamento. Este aumento na expressão deste gene é mantido após 1 h, atingindo um valor de 6 vezes após 24 horas de tratamento. 
A

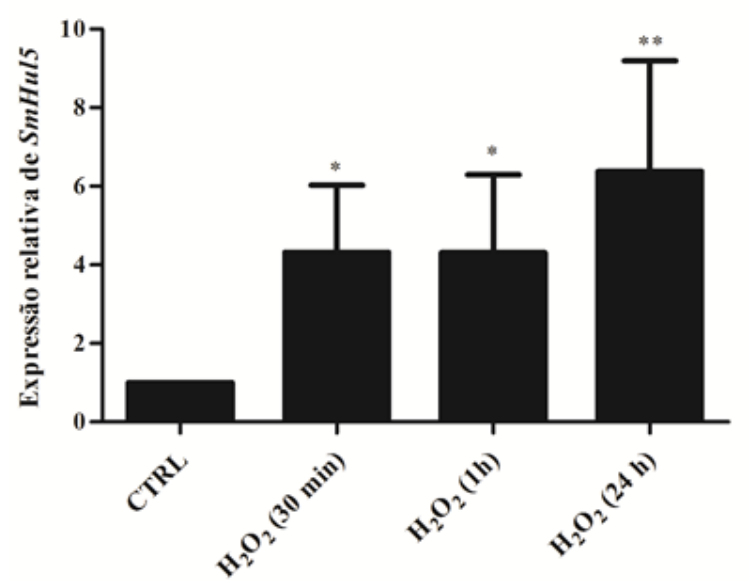

B

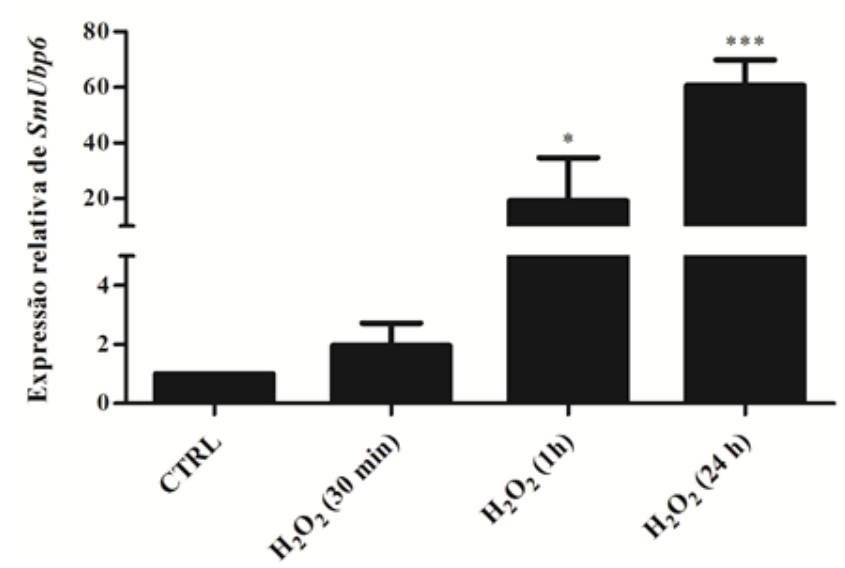

Figura 26. Expressão dos genes SmHul5 e SmUbp6 após estresse oxidativo. (A) Análise da expressão de SmHul5 e (B) Expressão de SmUbp6 após tratamento com peróxido de hidrogênio $(200 \mu \mathrm{M})$ por $30 \mathrm{~min}, 1 \mathrm{~h}$ e 24 h. *** Diferem significativamente do grupo controle (DMSO) através de Teste Tukey $(\mathrm{P}<0,0001)$, ** Diferem do controle através de Teste Tukey $(\mathrm{P}<0,001)$, * Diferem do controle através de Teste Tukey $(\mathrm{P}<0,05)$. O número relativo de transcritos de $S m H u l 5$ e SmUbp6 foi normalizado em relação ao gene endógeno GAPDH (Gliceraldeído-3 fosfato desidrogenase). Os resultados são provenientes de três experimentos independentes, e as reações foram preparadas em triplicata, sendo expressos como média \pm desvio padrão.

O nível de expressão do gene codificante da proteína Ubp6 também aumentou mediante condição de estresse oxidativo. Este aumento aconteceu inicialmente após $1 \mathrm{~h}$ de tratamento dos vermes adultos de $S$. mansoni, sendo a expressão cerca de 20 vezes maior em relação ao controle (Figura 26 B). Diferentemente do gene SmHul5, não foi observado um aumento na expressão deste gene após 30 minutos de tratamento. Por fim, foi possível observar altos níveis de expressão de SmUbp6 após 24 horas de tratamento com peróxido de hidrogênio.

\subsubsection{Western blotting para detecção de proteassoma $20 \mathrm{~S}$ em extrato bruto de vermes adultos oriundos de estresse oxidativo}

Inicialmente, $25 \mu \mathrm{g}$ de proteínas totais de vermes adultos oriundos de estresse oxidativo foram separadas em gel de poliacrilamida $12 \%$. Como mostrado na figura $27 \mathrm{~A}$, as proteínas foram corretamente carregadas no gel e apresentam uma boa qualidade. Na figura $27 \mathrm{~B}$, podemos observar um aumento no conteúdo proteico de proteassoma $20 \mathrm{~S}$ em vermes adultos após 30 minutos, 1 hora, 4 horas e 24 horas de tratamento com $200 \mu \mathrm{M}$ de peróxido 
de hidrogênio. $\mathrm{O}$ aumento no conteúdo proteico ocorre de forma mais evidente após 30 minutos e 1 hora de tratamento, tornando-se constante após 4 horas e 24 horas de tratamento. Assim, a partícula 20S parece estar relacionada com a resposta inicial ao estresse oxidativo.

Por outro lado, como mostrado na figura $27 \mathrm{~B}$, o nível proteico para a proteína endógena actina não variou devido ao estresse oxidativo. Além disso, podemos perceber que no nível de proteassoma $26 \mathrm{~S}$ indiretamente analisado pelo conteúdo intracelular da proteína RPN10 (subunidade do proteassoma), também não apresentou variações devido estresse oxidativo. Diante desta evidência, sugere-se que a resposta ao estresse oxidativo em vermes adultos de S. mansoni está relacionada com um aumento de subunidades $20 \mathrm{~S}$ do proteassoma, o qual pode envolvido na degradação de proteínas modificadas durante o estresse oxidativo.

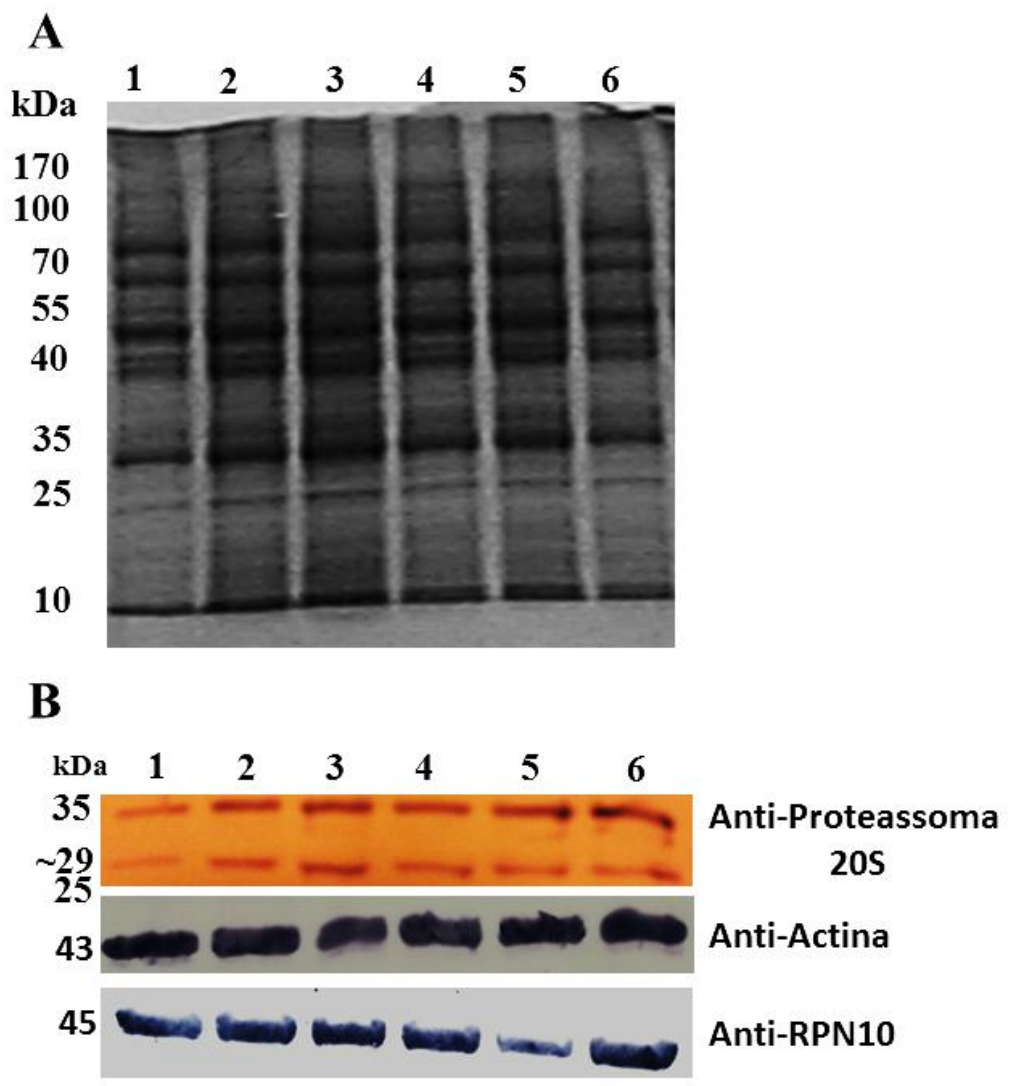

Figura 27. Detecção de proteassoma 20S durante estresse oxidativo. (A) Gel de poliacrilamida 12,5\% para $25 \mu \mathrm{g}$ de proteína total de vermes adultos de $S$. mansoni após estresse oxidativo e (B) Detecção dos níveis proteicos de proteassoma $20 \mathrm{~S}$ utilizando o anticorpo humano anti-proteassoma 20S. Como controle interno, foi utilizando o anticorpo anti-actina. (1) Controle (24 h), (2) $\mathrm{H}_{2} \mathrm{O}_{2}$ (30 minutos), (3) $\mathrm{H}_{2} \mathrm{O}_{2}$ (1 hora), (4) $\mathrm{H}_{2} \mathrm{O}_{2}$ (4 horas), (5) $\mathrm{H}_{2} \mathrm{O}_{2}$ (24 horas) e (6) MG132 (24 horas). Os resultados são provenientes de três experimentos independentes. kDa: Peso molecular de proteínas (PageRuler ${ }^{\mathrm{TM}}$ Prestained Protein Ladder - Thermo Scientific. 


\subsection{Caracterização do estresse químico e térmico}

\subsubsection{Determinação da produção de espécies reativas de oxigênio (ROS) no estresse químico com Curcumina, IBMX e MG132}

Para determinar se o estresse químico induzido com Curcumina, IBMX e MG132 está relacionado com a produção de ROS intracelular, a produção de ROS através do ensaio de NBT. A figura 28 mostra a produção de ROS intracelular mensurada através do ensaio de NBT após estresse químico com Curcumina, IBMX e MG132. Como podemos observar todos os compostos utilizados promoveram um aumento no nível intracelular de ROS quando comparado com o controle negativo (vermes adultos de $S$. mansoni tratados com DMSO 0,04\%).

A indução da produção de ROS intracelular pelo composto Curcumina tem sido descrita na literatura como sendo dependente da concentração e alguns autores sugerem um papel antioxidante para este composto em baixas concentrações. Para analisar este efeito, testamos aqui quatro concentrações de Curcumina: $5 \mu \mathrm{M}, 10 \mu \mathrm{M}, 15 \mu \mathrm{M}$ e $30 \mu \mathrm{M}$. Como podemos observar na figura $28 \mathrm{~A}$, todas as concentrações de Curcumina testadas induziram um aumento na produção de ROS intracelular em níveis que variaram de 2 a 3 vezes quando comparados como o controle positivo. Além disso, podemos observar também que a concentração de $5 \mu \mathrm{M}$ de Curcumina difere significativamente da outras concentrações testadas, apresentando uma produção de ROS menor em relação as maiores concentrações da substância.

Analisando as figuras $28 \mathrm{~B}$ e $\mathrm{C}$, podemos perceber que os compostos IBMX e MG132 provocaram um aumento no ROS intracelular igual a 2 vezes em relação ao controle e, além disso, é possível observar que as duas concentrações de IBMX testadas neste trabalho não diferem entre si quanto à geração de ROS intracelular. 
$\mathbf{A}$

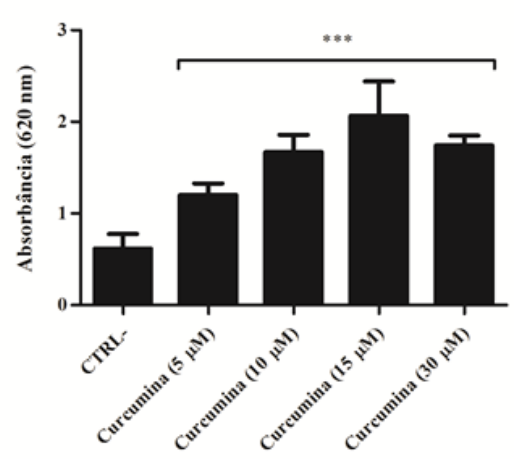

B

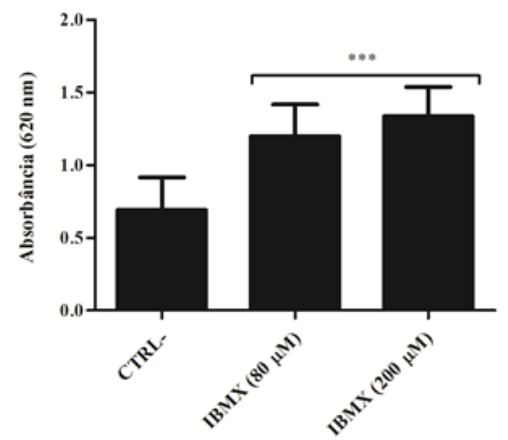

$\mathrm{C}$

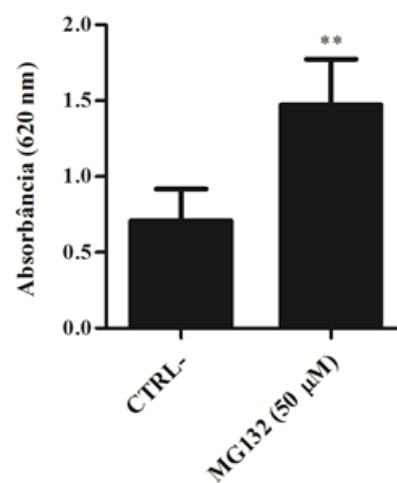

Figura 28. Produção de ROS em vermes adultos de $S$. mansoni após estresse químico. A produção de ânions superóxidos foi mensurada pela conversão de NBT em cristais de formazan, onde um incremento na absorbância indica um aumento na produção de ROS celular. (A) Curcumina e produção de ROS, (B) IBMX e produção de ROS e (C) MG132 e produção de ROS. Controle negativo (CTRL-): vermes adultos de $S$. mansoni tratados com DMSO 0,04\%. *** Diferem do controle negativo através de Teste $\mathrm{t}$ de Dunnett $(\mathrm{P}<0,0001)$, ** Difere do controle negativo através de Teste $\mathrm{t}$ de Dunnett $(\mathrm{P}<0,001)$. Os resultados são provenientes de três experimentos independentes, e as reações foram preparadas em triplicata, sendo expressos como média \pm desvio padrão.

\subsubsection{Análise de expressão de genes do sistema de defesa de $S$. mansoni mediante condição de estresse químico}

Para analisar se o aumento na produção de ROS por vermes adultos de S. mansoni após estresse químico modula a expressão de genes relacionados aos sistemas de defesa antioxidante bem como de protéinas de choque térmico do parasito, foi realizada a análise

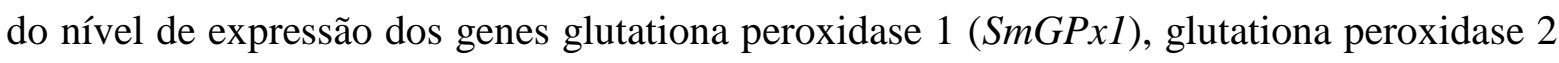
$(S m G P x 2)$, superóxido dismutase $(S m S O D)$, tiorredoxina redutase $(S m T G R)$ e para as 
proteínas de choque térmico $S m H s p 70$ e $S m H s p 40$ após estresse químico induzido com Curcumina, IBMX e MG132.

Como mostrado na figura 29 alguns genes do sistema de defesa antioxidante de $S$. mansoni tiveram sua expressão induzida após estresse químico de vermes adultos com Curcumina, IBMX e MG132. O nível de expressão dos quatro genes analisados (SmGPxl, SmGPx2, SmSOD e SmTGR) não variaram em relação ao controle nos tratamentos com 80 $\mu \mathrm{M}$ de IBMX e $50 \mu \mathrm{M}$ de MG132.

A

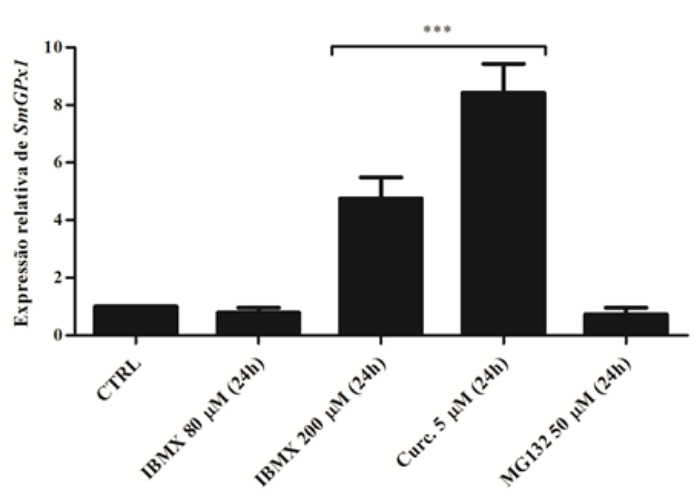

C

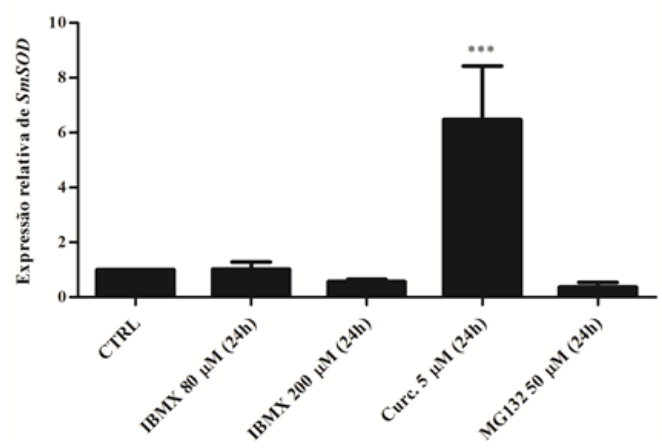

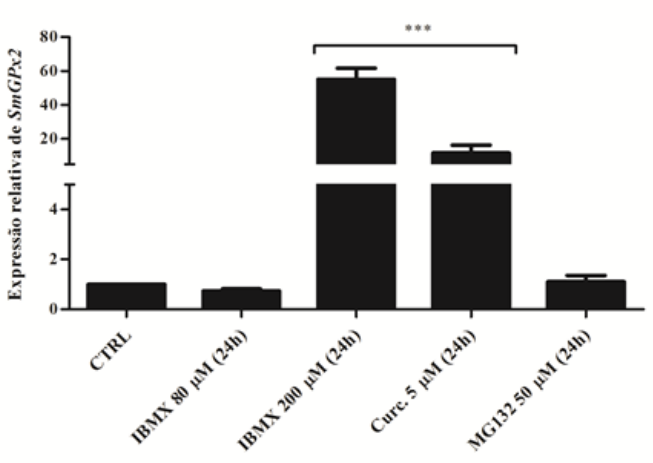

D

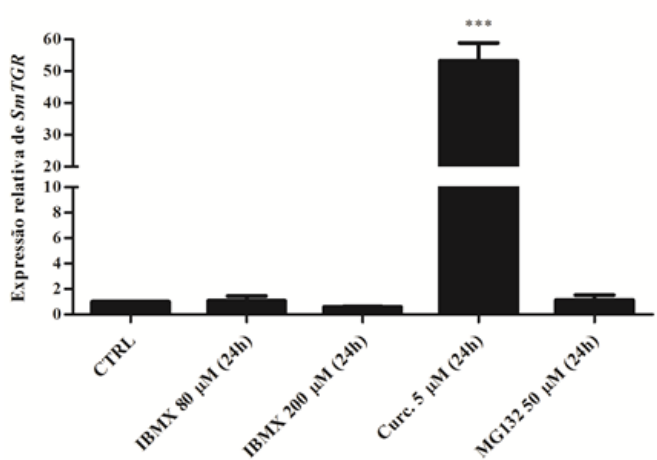

Figura 29. Expressão de genes do sistema de defesa antioxidante de $S$. mansoni no estresse químico. Análise da expressão dos genes (A) SmGPxl, (B) SmGPx2, (C) $S m S O D$ e (D) $S m T G R$. *** Diferem significativamente do grupo controle (DMSO) através de Teste Tukey $(\mathrm{P}<0,0001)$. O número relativo de transcritos foi normalizado em relação ao gene endógeno GAPDH (Gliceraldeído-3 fosfato desidrogenase). Os resultados são provenientes de três experimentos independentes, e as reações foram preparadas em triplicata, sendo expressos como média \pm desvio padrão. 
Por outro lado, o tratamento com $200 \mu \mathrm{M}$ de IBMX e $5 \mu \mathrm{M}$ de Curcumina promoveram um aumento no nível de expressão de $\operatorname{SmGPx1}$ e $\operatorname{SmGPx2}$ (Figura 29 A e B). Por fim, podemos observar que em relação aos genes $S m S O D$ e $S m T G R$, houve alteração no nível de expressão somente no tratamento com $5 \mu \mathrm{M}$ de Curcumina (Figura $29 \mathrm{C}$ e D). Deste modo, o estresse químico com os compostos Curcumina, IBMX e MG132 modula de forma diferencial a expressão de genes do sistema de defesa de vermes adultos de $S$. mansoni.

Outros dois genes cuja expressão foi avaliada mediante estresse químico foram os genes para as proteínas de choque térmico $S m H s p 70$ e $S m H s p 40$. Como mostrado na figura 30 A e B, os dois genes apresentam um aumento na sua expressão mediante tratamento de vermes adultos de $S$. mansoni com $80 \mu \mathrm{M}$ de IBMX e $5 \mu \mathrm{M}$ de Curcumina. O aumento na expressão para $S m H s p 70$ e SmHsp40 não observado para o tratamento com $200 \mu \mathrm{M}$ de IBMX. As protéinas de choque térmico são chaperonas moleculares descritas como importantes para resposta a diferentes tipos de estresse, principalmente o estresse oxidativo. Deste modo, aumento da expressão desses dois genes no estresse com IBMX e Curcumina evidencia a participação destas chaperonas como parte do mecanismo de resposta ao estresse químico gerado por estes dois compostos.

A

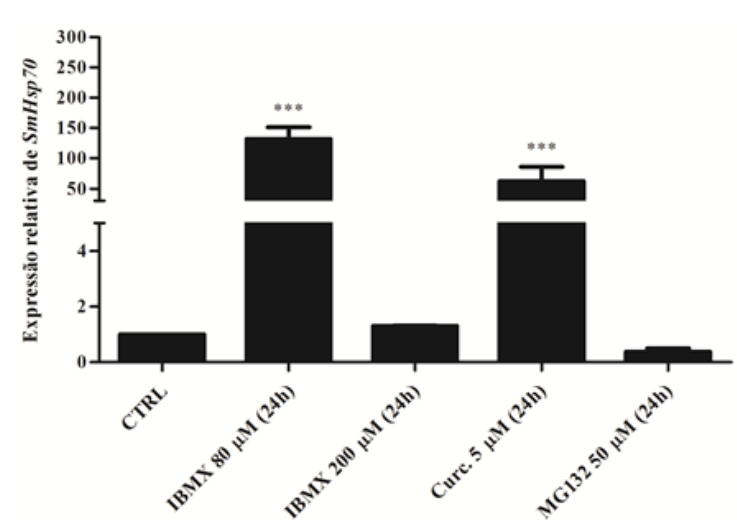

B

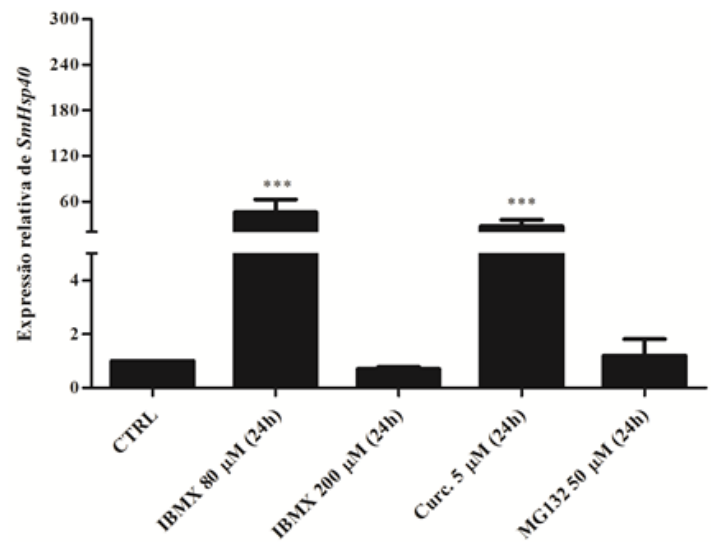

Figura 30. Expressão de genes para proteínas de choque térmico no estresse químico. Análise da expressão dos genes (A) $S m H s p 70$ e (B) $S m H s p 40$. *** Diferem significativamente do grupo controle (DMSO) através de Teste Tukey $(\mathrm{P}<0,0001)$. O número relativo de transcritos foi normalizado em relação ao gene endógeno GAPDH (Gliceraldeído-3 fosfato desidrogenase). Os resultados são provenientes de três experimentos independentes, e as reações foram preparadas em triplicata, sendo expressos como média \pm desvio padrão. 


\subsubsection{Perfil de expressão de $\mathrm{SmHul5}$ e $S m U b p 6$ no estresse químico e térmico}

\subsubsection{Estresse químico}

O nível de transcritos para os genes SmHul5 e SmUbp6 foram analisados após estresse químico com os compostos IBMX, Curcumina e MG132. O perfil de expressão de SmHul5 após tratamento dos vermes adultos de S. mansoni com o composto IBMX é demonstrado na figura 31. Conforme observado na figura 31 A, o nível de expressão de SmHul5 apresenta um pico após 48 h de cultivo in vitro, sendo relativamente baixo em $24 \mathrm{~h}$ e 72 h de cultivo. O tratamento com IBMX promoveu uma drástica diminuição na expressão deste gene após o tratamento de vermes adultos de $S$. mansoni por 48 h e 72 h com 80 e 200 $\mu \mathrm{M}$ do composto IBMX (Figura $31 \mathrm{~B}$ e C). Na figura $31 \mathrm{C}$, observamos um perfil de expressão semelhante em vermes adultos de S.mansoni tratados com $200 \mu \mathrm{M}$ de IBMX, no entanto, em contraste com a concentração de $80 \mu \mathrm{M}$, ocorre um aumento na expressão de SmHul5 no tempo de 24 h de cultivo, sendo a diminuição da expressão gênica mantida após $48 \mathrm{~h}$ ou $72 \mathrm{~h}$ de tratamento. 

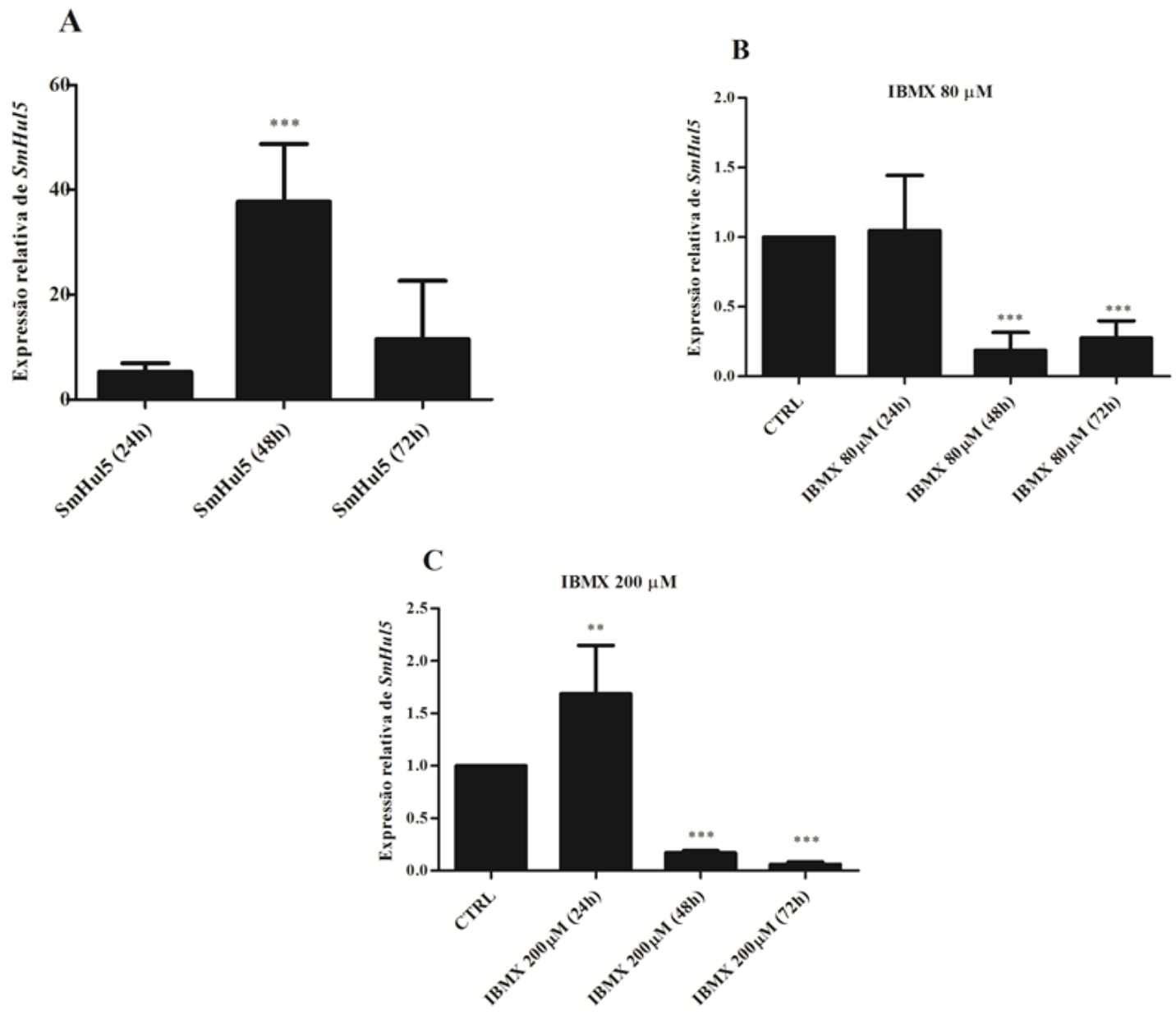

Figura 31. Expressão do gene SmHul5 após estresse químico com IBMX. (A) Análise de expressão de SmHul5 após 24 h, 48 h e 72 h de cultivo in vitro em vermes adultos não tratados, (B) Análise da expressão SmHul5 após tratamento com $80 \mu \mathrm{M}$ de IBMX por 24 h, 48 h e 72 h e (C) Análise da expressão SmHul5 após tratamento com $200 \mu \mathrm{M}$ de IBMX por $24 \mathrm{~h}, 48 \mathrm{~h}$ e $72 \mathrm{~h}$. (A) *** Diferem significativamente de $S m H u l 524 \mathrm{~h}$ e SmHul5 $72 \mathrm{~h}$ através de Teste Tukey $(\mathrm{P}<0,0001)$, (B) *** Diferem do controle através de Teste Tukey $(\mathrm{P}<0,0001)$, (C) *** Difere do controle $(\mathrm{P}<0,0001)$. O número relativo de transcritos de SmHul5 foram normalizados em relação ao gene endógeno GAPDH (Gliceraldeído-3 fosfato desidrogenase). Os resultados são provenientes de três experimentos independentes, e as reações foram preparadas em triplicata, sendo expressos como média \pm desvio padrão.

O perfil de expressão de SmUbp6 é semelhante a SmHul5, e como mostrado na figura 32 A, existe um pico de expressão de SmUbp6 após $48 \mathrm{~h}$ de cultivo in vitro. $\mathrm{O}$ tratamento com IBMX levou a uma diminuição na expressão de SmUbp6 após 48 h de cultivo in vitro com a concentração de $80 \mu \mathrm{M}$ (Figura $32 \mathrm{~B}$ ). Além disso, não houve diferença significativa entre os tratamentos de $24 \mathrm{~h}$ e $72 \mathrm{~h}$ quando comparados com o tratamento controle (Figura $32 \mathrm{~B}$ ).

Para a concentração de $200 \mu \mathrm{M}$ de IBMX os efeitos foram diferentes dos observados para a concentração de $80 \mu \mathrm{M}$. Após 24 h de tratamento, a expressão de SmUbp6 
mostrou níveis similares em relação ao tratamento controle. Já nos tempos de 48 h e 72 h de cultivo foi observada brusca redução na expressão gênica de $\operatorname{SmUbp6}$, sendo os níveis de expressão cerca de 7 vezes (IBMX $200 \mu$ M 48h) a 8 vezes (IBMX $200 \mu$ M 72h) menores em comparação ao grupo controle.

O perfil de expressão de SmHul5 e SmUbp6 após tratamento dos vermes adultos de S. mansoni com os compostos Curcumina e MG132 são mostrados na figura 33. Como podemos observar, o tratamento com Curcumina nas concentrações de $5 \mu \mathrm{M}$ e $10 \mu \mathrm{M}$ por 24 h promoveu um aumento de aproximadamente 4 vezes na expressão de SmHul5 (Figura 33 A). Além disso, quando os vermes foram tratados com o inibidor do proteassoma (MG132) na concentração de $50 \mu \mathrm{M}$, houve aumento significativo na expressão de SmHul5 nos tempos de $24 \mathrm{~h}$ e $48 \mathrm{~h}$ de tratamento (Figura $33 \mathrm{~A}$ ).
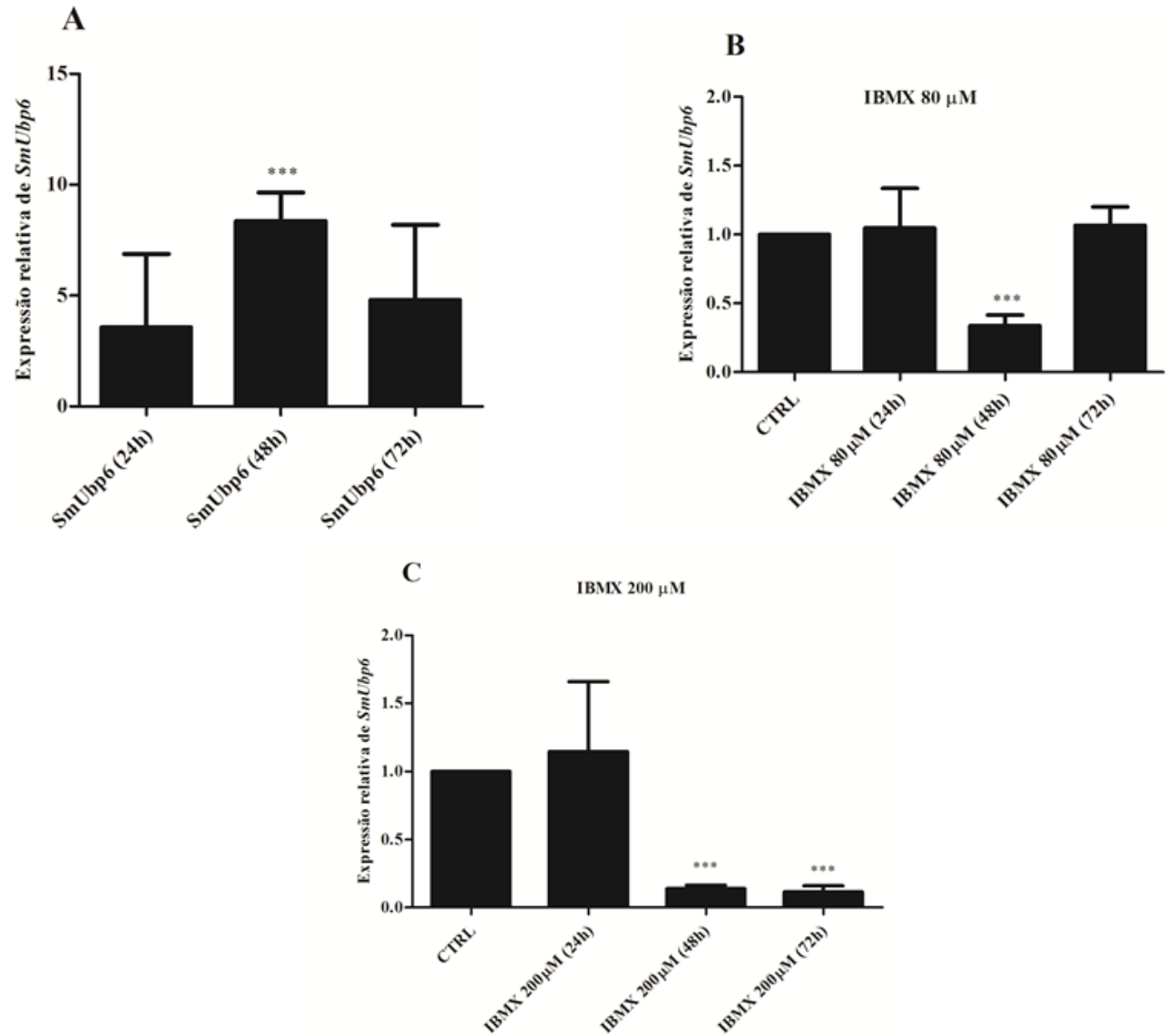

Figura 32. Expressão do gene SmUbp6 após estresse químico com IBMX. (A) Análise de expressão de SmUbp6 após 24 h, 48 h e 72 h de cultivo in vitro em vermes adultos não tratados, (B) Análise da expressão SmUbp6 após tratamento com $80 \mu \mathrm{M}$ de IBMX por 24 h, 48 h e 72 h e (C) Análise da expressão SmUbp6 após tratamento com $200 \mu \mathrm{M}$ de IBMX por $24 \mathrm{~h}, 48 \mathrm{~h}$ e $72 \mathrm{~h}$. (A) *** Diferem significativamente de SmUbp6 24h e SmUbp6 $72 \mathrm{~h}$ através de Teste Tukey $(\mathrm{P}<0,0001)$, (B) *** Diferem do controle através de Teste Tukey, (C) *** Difere do controle $(\mathrm{P}<0,0001)$. O número relativo de transcritos de SmUbp6 foram normalizados em relação ao gene endógeno GAPDH (Gliceraldeído-3 fosfato desidrogenase). Os resultados são provenientes de três experimentos independentes, e as reações foram preparadas em triplicata, sendo expressos como média \pm desvio padrão. 
A

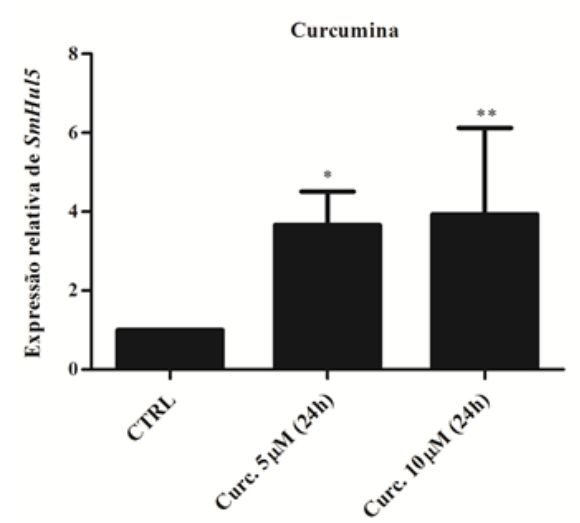

B

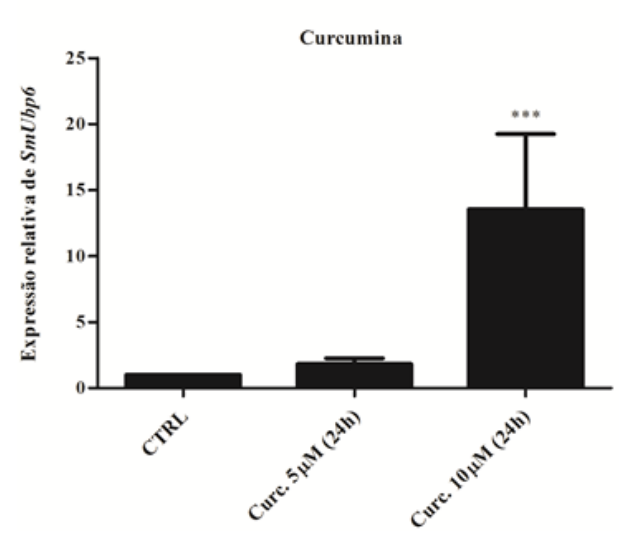

MG132

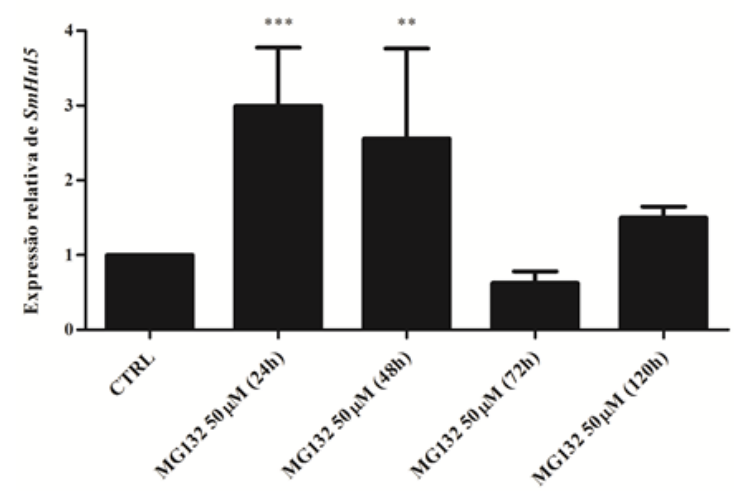

MG132

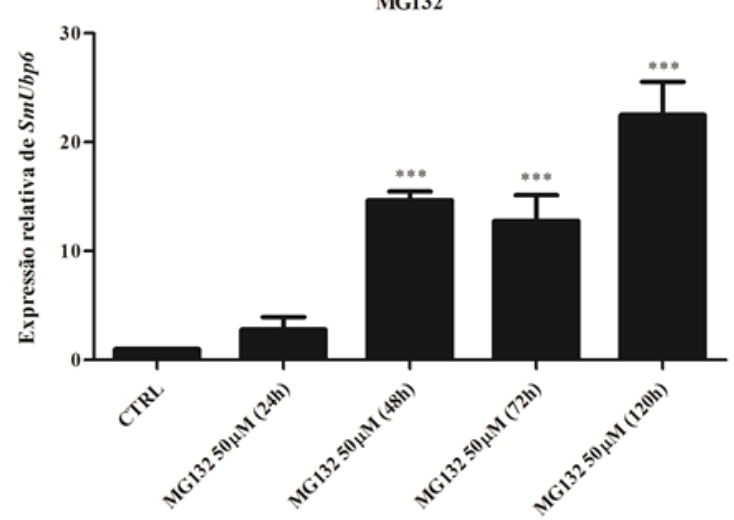

Figura 33. Expressão dos genes SmHul5 e SmUbp6 após estresse químico com Curcumina e MG132. (A) Análise da expressão de $S m H u l 5$ e (B) Expressão de SmUbp6 após tratamento com Curcumina $(5$ e $10 \mu \mathrm{M})$ por $24 \mathrm{~h}$ e MG132 $(50 \mu \mathrm{M})$ por $24 \mathrm{~h}, 48 \mathrm{~h}, 72 \mathrm{~h}$ e $120 \mathrm{~h}$. *** Diferem significativamente do grupo controle (DMSO) através de Teste Tukey $(\mathrm{P}<0,0001)$, ** Diferem do controle através de Teste Tukey $(\mathrm{P}<0,001)$, * Diferem do controle através de Teste Tukey $(\mathrm{P}<0,05)$. O número relativo de transcritos de SmHul5 e SmUbp6 foi normalizado em relação ao gene endógeno GAPDH (Gliceraldeído-3 fosfato desidrogenase). Os resultados são provenientes de três experimentos independentes, e as reações foram preparadas em triplicata, sendo expressos como média \pm desvio padrão.

Para o gene SmUbp6 os níveis de expressão também variaram após o tratamento de vermes adultos com Curcumina $(10 \mu \mathrm{M})$ por $24 \mathrm{~h}$ e MG132 $50 \mu \mathrm{M}$ nos tempos de $48 \mathrm{~h}, 72 \mathrm{~h}$ e 120 h, sendo o nível de expressão após 120 h de tratamento cerca de 20 vezes maior em relação ao controle (Figura $33 \mathrm{~B}$ ). Desta forma, observamos que tanto o tratamento com Curcumina quanto com MG132 promoveu de maneira similar um aumento na expressão de SmHul5 e SmUbp6, indicando, que os dois compostos podem de alguma maneira regular a expressão de genes relacionados ao sistema de ubiquitina-proteassoma. 


\subsubsection{Estresse térmico}

A expressão gênica pode ser regulada diante de uma grande diversidade de situações de estresse celular. Como podemos observar a expressão de SmHul5 e SmUbp6 da mesma forma, mostrou ser regulada mediante diferentes condições de estresse. Na figura 34 observamos o nível de transcritos de SmHul5 e SmUbp6 após tratamento de estresse térmico. O nível de expressão de $\operatorname{SmHul5}$ a $40^{\circ} \mathrm{C}$ não difere do controle (vermes adultos mantidos a $37^{\circ} \mathrm{C}$ por 1 hora). No entanto, a elevação da temperatura para $42^{\circ} \mathrm{C}$ promoveu um aumento na expressão deste gene, sendo o nível de expressão 2,5 vezes maior em relação ao grupo controle (Figura 34 A). Para o gene SmUbp6 o nível de expressão gênica não foi alterado na temperatura de $42^{\circ} \mathrm{C}$, porém, foi observado um aumento de aproximadamente uma vez em sua expressão na temperatura de $40^{\circ} \mathrm{C}$ (Figura $34 \mathrm{~B}$ ). Estes resultados sugerem que o gene SmHul5 pode estar regulado por mecanismos que estão relacionados com a resposta a elevação de temperatura, enquanto que o gene SmUbp6 está regulado em condições de menores temperaturas.

A

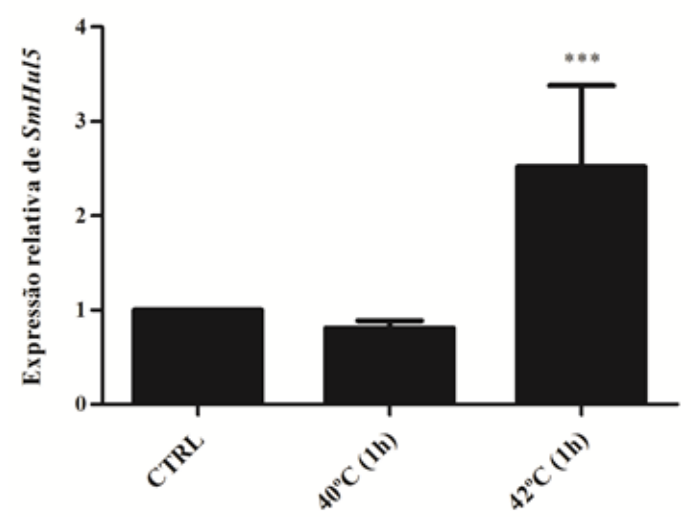

B

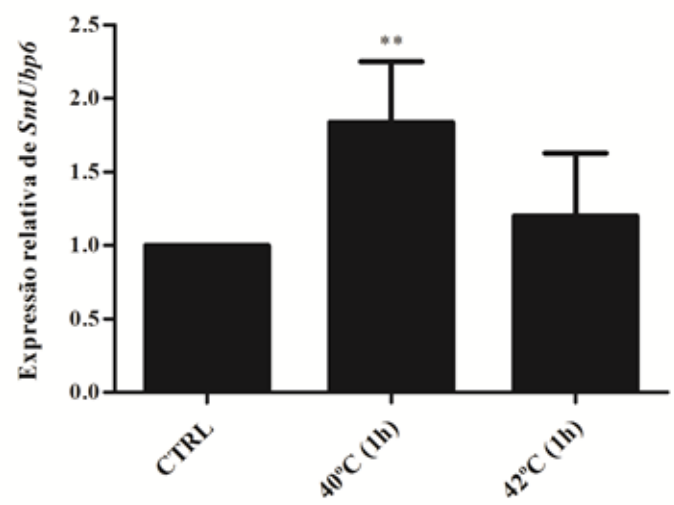

Figura 34. Expressão diferencial dos genes $S m H u l 5$ e SmUbp6 após estresse térmico. (A) Análise da expressão de SmHul5 e (B) Expressão de SmUbp6 após estresse térmico nas temperaturas de $40^{\circ} \mathrm{C}$ e $42^{\circ} \mathrm{C}$ por 1 h. *** Diferem significativamente do grupo controle (vermes mantidos a $37^{\circ} \mathrm{C}$ ) através de Teste Tukey $(\mathrm{P}<0,0001)$, ** Diferem do controle através de Teste Tukey $(\mathrm{P}<0,001)$. O número relativo de transcritos de SmHul5 e SmUbp6 foi normalizado em relação ao gene endógeno GAPDH (Gliceraldeído-3 fosfato desidrogenase). Os resultados são provenientes de três experimentos independentes, e as reações foram preparadas em triplicata, sendo expressos como média \pm desvio padrão. 


\subsubsection{Perfil de expressão de $\operatorname{SmPOMP}$ em diferentes condições de estresse do proteassoma de $S$. mansoni}

A proteína POMP (Proteína de Maturação do Proteassoma) é um marcador molecular de montagem e desmontagem do proteassoma. Esta proteína está presente em complexos precursores e, é imediatamente degradada após a completa montagem da partícula 20S, estando presente em situações fisiológicas onde é necessária a síntese de novas populações de proteassoma. Nosso grupo de trabalho caracterizou inicialmente esta proteína na condição de estresse químico induzido com IBMX e na condição de estresse térmico. Neste trabalho, foi analisado o nível de expressão do gene SmPOMP após estresse químico induzido com Curcumina e MG132 bem como na condição de estresse oxidativo.

Como podemos observar na figura 35 A, a expressão de SmPOMP aumentou após o tratamento com Curcumina nas concentrações de $5 \mu \mathrm{M}$ e $10 \mu \mathrm{M}$ após $24 \mathrm{~h}$. O aumento na expressão de SmPOMP também pode ser observado no tratamento com MG132. Neste caso, o aumento na expressão deste gene ocorreu de forma crescente a partir de $48 \mathrm{~h}$ de tratamento, atingindo um nível máximo no tempo de 120 h, onde o nível de expressão foi cerca de 10 vezes maior em comparação ao grupo controle (Figura 35 B). No entanto, os valores de expressão para este gene não apresentaram diferença estatística significativa entre os tempos de 48 h, $72 \mathrm{~h}$ e $120 \mathrm{~h}$ de tratamento.

Em relação ao estresse oxidativo podemos observar um aumento significativo na expressão de SmPOMP após 30 minutos e $1 \mathrm{~h}$ de tratamento de vermes adultos de $S$. mansoni com $200 \mu \mathrm{M}$ de peróxido de hidrogênio. Este aumento foi de aproximadamente 3 vezes e 4 vezes maior em relação ao grupo controle para os tratamento de 30 minutos e de 1 hora, respectivamente (Figura $35 \mathrm{C}$ ). Quanto ao tratamento de $24 \mathrm{~h}$, não foi observada diferença significativa no nível de expressão de SmPOMP quando comparado com o grupo controle. 
A

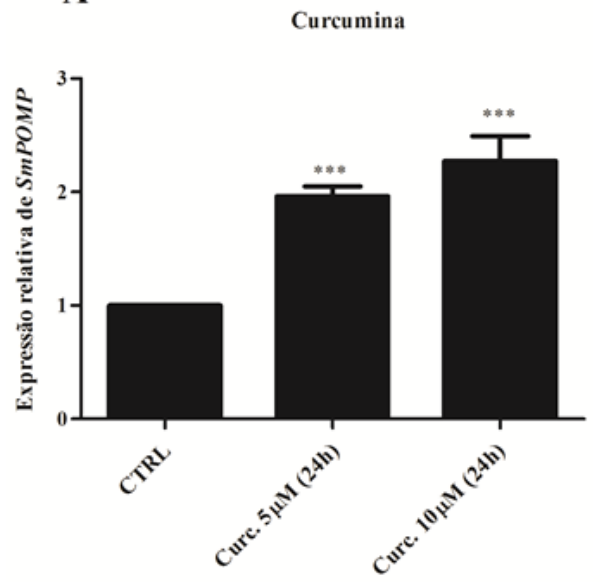

B

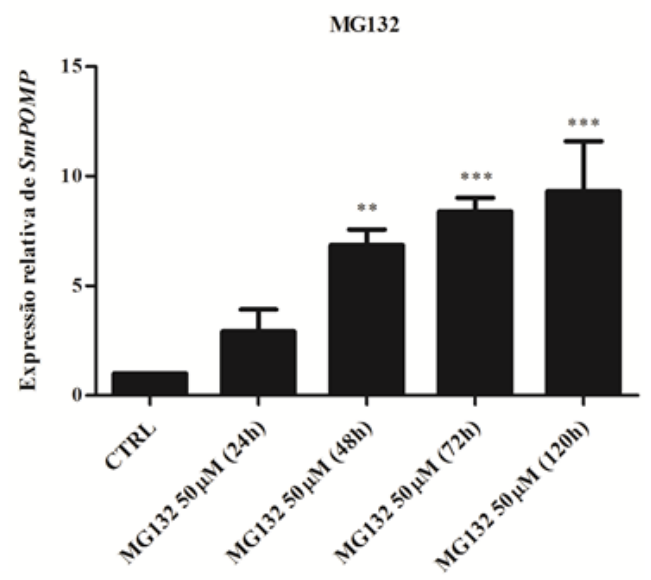

C

$\mathrm{H}_{2} \mathrm{O}_{2}$

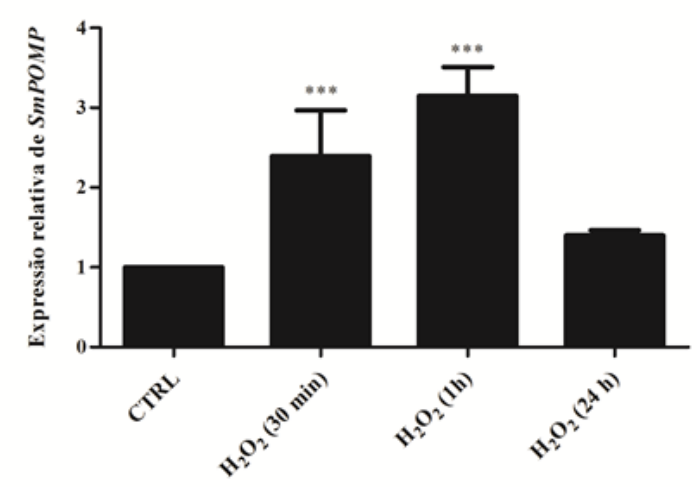

Figura 35. Expressão de SmPOMP após estresse químico e estresse oxidativo. Análise da expressão de SmPOMP mediante condição de estresse químico (A) Curcumina, (B) MG132 e (C) estresse oxidativo $\left(\mathrm{H}_{2} \mathrm{O}_{2}\right)$. *** Diferem significativamente do grupo controle (DMSO) através de Teste Tukey $(\mathrm{P}<0,0001)$, ** Diferem do controle através de Teste Tukey $(\mathrm{P}<0,001)$. O número relativo de transcritos de SmPOMP foi normalizado em relação ao gene endógeno GAPDH (Gliceraldeído-3 fosfato desidrogenase). Os resultados são provenientes de três experimentos independentes, e as reações foram preparadas em triplicata, sendo expressos como média \pm desvio padrão.

\subsection{Resposta in vitro ao estresse térmico}

Quanto ao estresse térmico, vermes adultos de $S$. mansoni foram expostos a diferentes temperaturas $\left(37^{\circ} \mathrm{C}, 40^{\circ} \mathrm{C}, 42^{\circ} \mathrm{C}\right)$, sendo recuperados 1 hora após cada tratamento. Conforme demonstrado na figura 36 , a viabilidade dos vermes não foi alterada nas diferentes temperaturas. Os dados diferentes somente em relação ao controle positivo (vermes adultos mortos a $56^{\circ} \mathrm{C}$ por 15 minutos). 


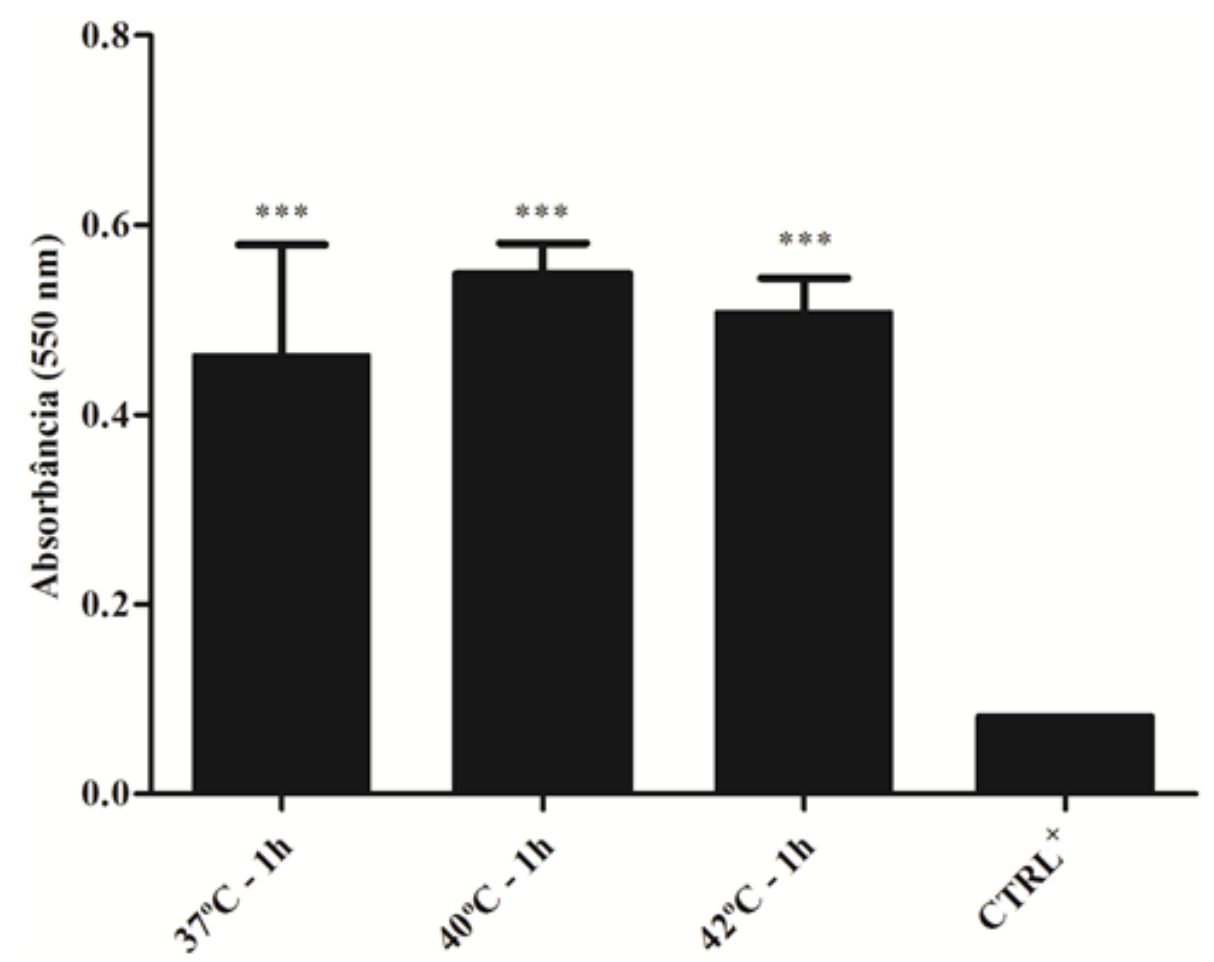

Figura 36. Viabilidade de vermes adultos de $S$. mansoni após indução de estresse térmico. Estresse térmico foi induzido em três diferentes temperaturas $\left(37^{\circ} \mathrm{C}, 40^{\circ} \mathrm{C}, 42^{\circ} \mathrm{C}\right)$ por $1 \mathrm{~h}$. Resultado obtido após três experimentos independentes, sendo as reações preparadas em quadruplicata. $* * *$ Diferem do controle positivo (vermes adultos mortos a $56^{\circ} \mathrm{C}$ por 15 minutos) após Teste Tukey com $\mathrm{P}<0,0001$.

Como o objetivo de entender os mecanismos envolvidos na resposta de vermes adultos de $S$. mansoni ao estresse térmico, realizamos a identificação de proteínas diferencialmente expressas nesta condição através de eletroforese bidimensional e espectrometria de massas. Para isto, utilizamos extratos proteicos totais de vermes adultos submetidos a estresse térmico a $42^{\circ} \mathrm{C}$ por 1 hora. Esta temperatura e tempo foram escolhidos pelo fato de não alterarem a viabilidade de vermes adultos e também por terem sido citados em outros trabalhos na literatura como sendo capazes de induzir estresse térmico em $S$. mansoni. 


\subsection{Perfil de expressão proteica de vermes adultos de $S$. mansoni em resposta a estresse oxidativo e térmico}

Proteínas totais de vermes adultos submetidos a estresse oxidativo e térmico foram separadas através de eletroforese bidimensional e as proteínas expressas foram identificadas por espectrometria de massas. Na figura (37 B), está representado o gel bidimensional para proteínas totais de vermes adultos oriundas de estresse oxidativo $(200 \mu \mathrm{M}$ de peróxido de hidrogênio) em comparação com proteínas totais de vermes adultos controle (Figura 37 A) e na figura 38 está representado o gel para o estresse térmico. Como podemos observar as proteínas representadas na figura 37 B pelos números $1,2,3,4,5,6,7,8,10,11,12,13,15$, $16,17,21,22,23,29,32,33$ e 36 tiveram sua expressão induzida após estresse oxidativo. $\mathrm{Na}$ figura 38, podemos visualizar as proteínas que tiveram sua expressão induzida após estresse térmico, desta forma, as proteínas representadas na figura pelos números $1,4,5,7$, $8,9,10,11,13,14,17,18,19,20,21,23,24,27,30,31,33,34,35$ e 38 indicam proteínas upreguladas nesta condição.

Na tabela 6 mostra a descrição completa de todas as proteínas expressas na condição de estresse oxidativo e térmico, mostrando o número do spot em cada gel, o número de acesso no banco de dados do NCBI, gene Smp (identificação no banco de dados de $S$. mansoni), descrição da proteína, score, massa molecular, ponto isoelétrico, porcentagem de cobertura, sublocalização celular e condição de expressão. 


\section{Controle}

$200 \mu \mathrm{M}$ H2O2

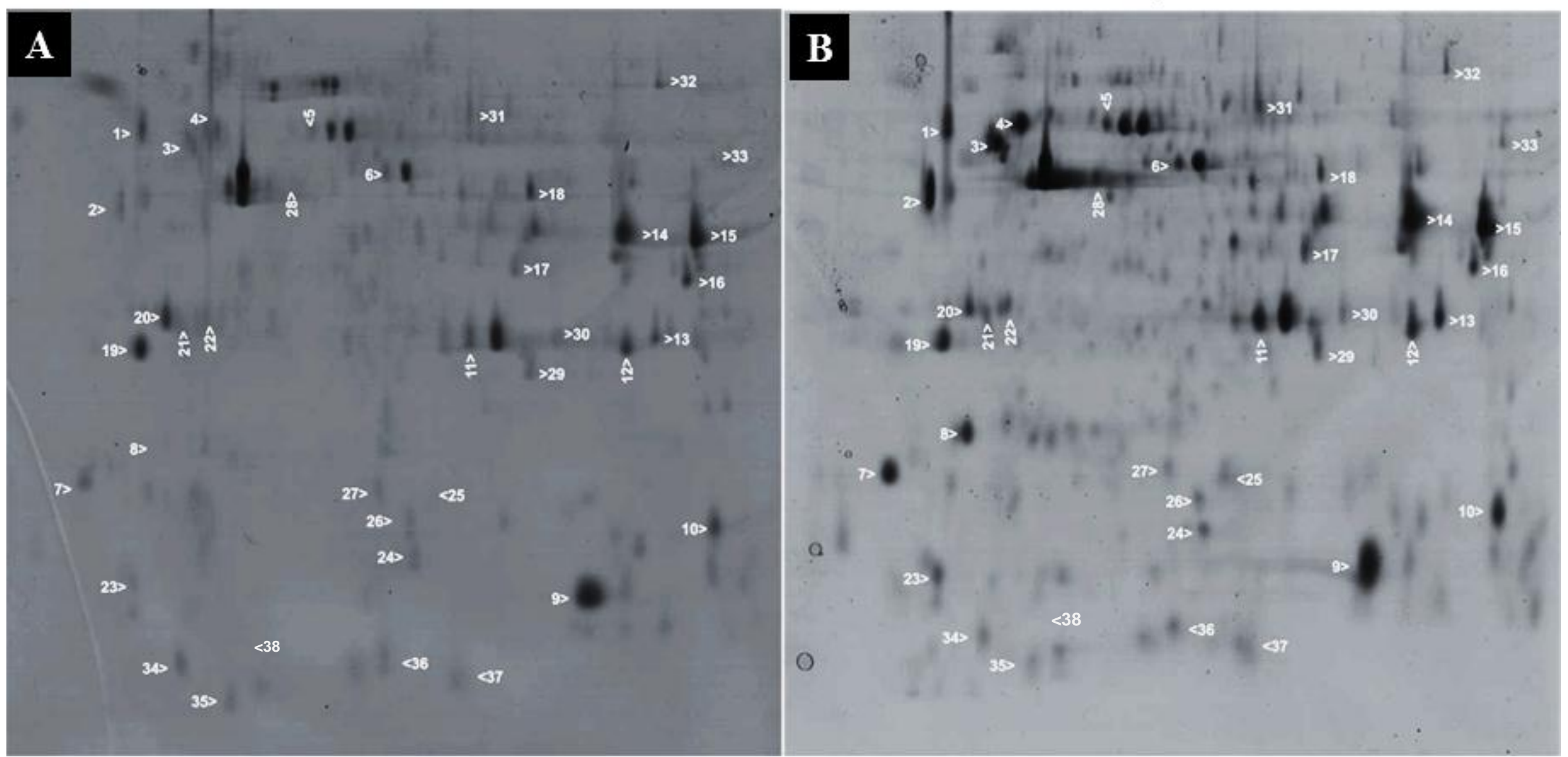

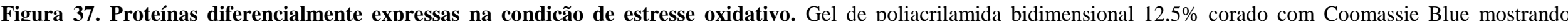

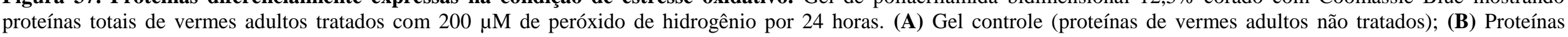
oriundas de vermes adultos submetidos a estresse oxidativo. Os números e as setas indicam as proteínas com expressão diferencial. 


\section{Controle}

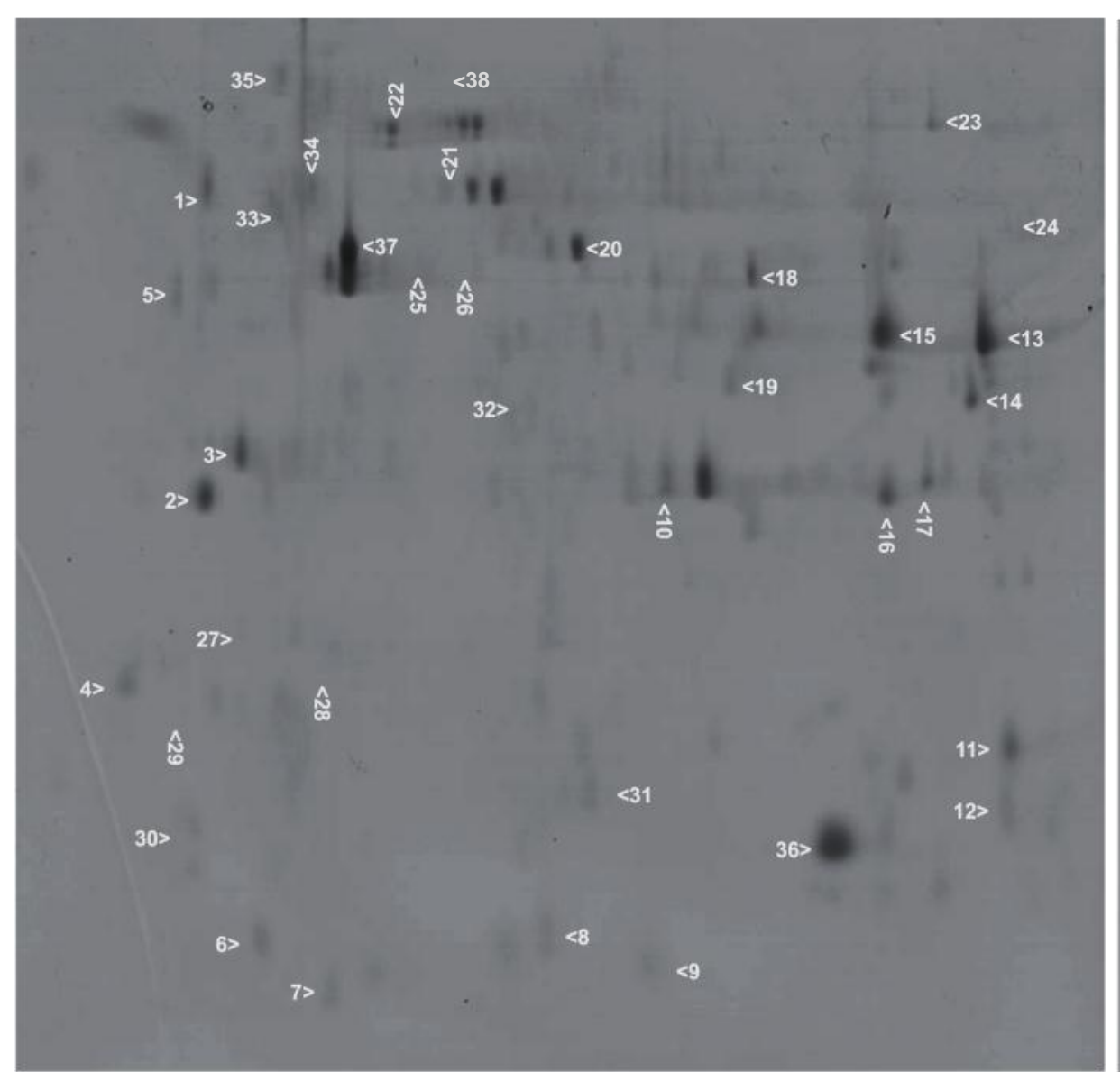

$42^{\circ} \mathrm{C}$

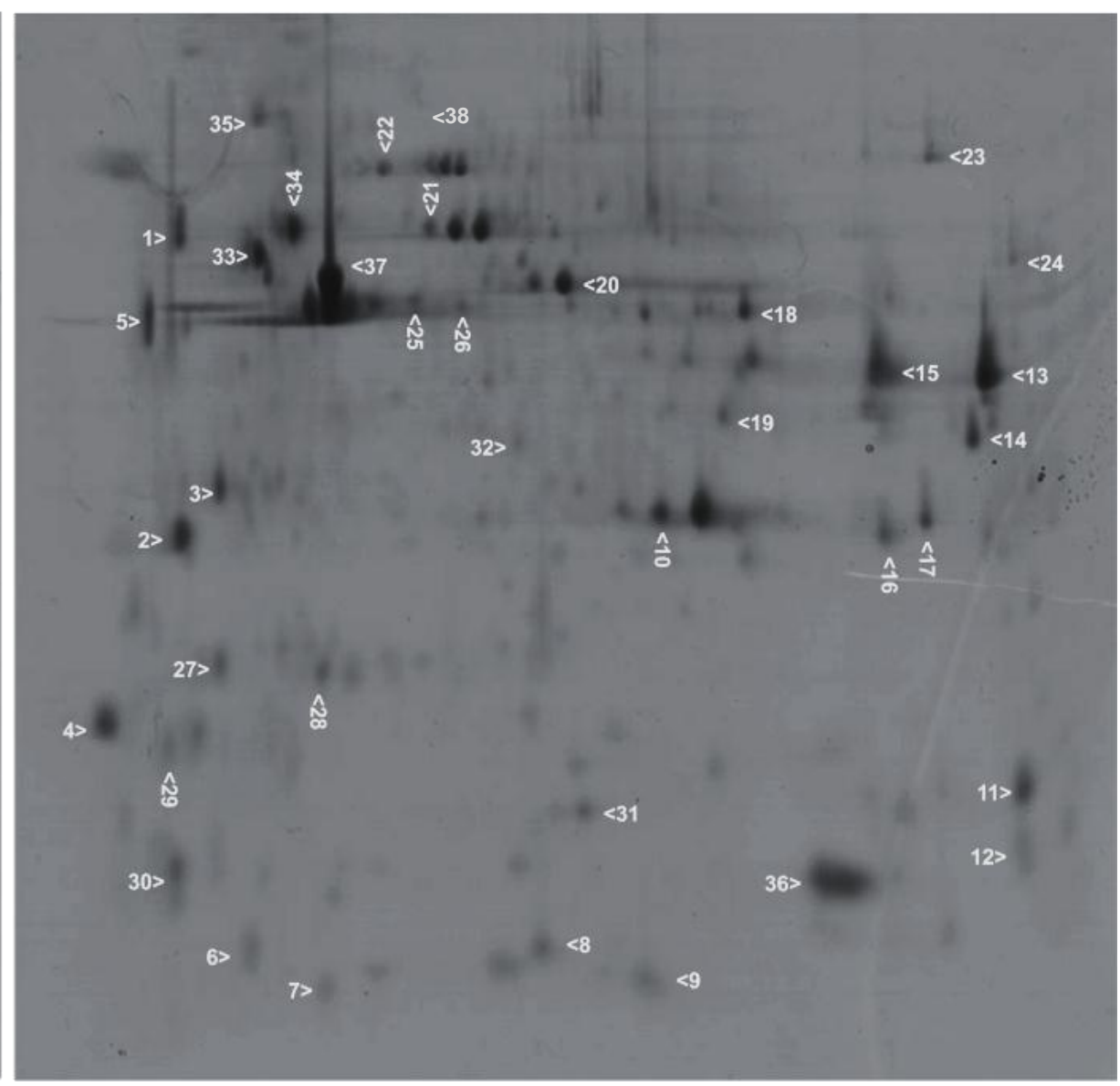

Figura 38. Proteínas diferencialmente expressas na condição de estresse térmico. Gel de poliacrilamida bidimensional 12,5\% corado com Coomassie Blue mostrando proteínas totais de vermes adultos submetidos a estresse térmico a $42^{\circ} \mathrm{C}$ por 1 hora. (A) Gel controle (proteínas de vermes adultos mantidos a $37^{\circ} \mathrm{C}$ por 1 hora); (B) Proteínas oriundas de vermes adultos submetidos a estresse térmico. Os números e as setas indicam as proteínas com expressão diferencial. 
Tabela 6. Proteínas identificadas após estresse oxidativo e estresse térmico.

$\begin{array}{cccc}\begin{array}{c}\text { Spot } \\ \text { O }\end{array} & \begin{array}{c}\text { Spot } \\ \text { T }\end{array} & \text { NCBI } & \text { Gene Smp } \\ 1 & 1 & \text { CAZ30718.2 } & \text { Smp_030370.1 } \\ 2 & 5 & \text { XP_002574611.1 } & \text { Smp_031770.4 } \\ 3 & 33 & \text { CCD59122.1 } & \text { Smp_030730.1 } \\ 4 & 34 & \text { XP_002580033.1 } & \text { Smp_090120.1 } \\ 5 & 21 & \text { XP_002576343.1 } & \text { Smp_050390.1 } \\ 6 & 20 & \text { CCD82493.1 } & \text { Smp_024110.1 } \\ 7 & 4 & \text { XP_002572005.1 } & \text { Smp_005350.1 } \\ 8 & 27 & \text { XP_002573367.1 } & \text { Smp_132670.1 } \\ 9 & 36 & \text { XP_002580432.1 } & \text { Smp_095360.1 } \\ 10 & 11 & \text { XP_002575376.1 } & \text { Smp_040130.1 } \\ 11 & 10 & \text { XP_002576704.1 } & \text { Smp_054160.1 } \\ 12 & 16 & \text { XP_002571861.1 } & \text { Smp_003990.1 } \\ 13 & 17 & \text { XP_002580559.1 } & \text { Smp_096760.1 } \\ 14 & 15 & \text { XP_002575564.1 } & \text { Smp_042160.2 } \\ 15 & 13 & \text { XP_002576993.1 } & \text { Smp_056970.1 } \\ 16 & 14 & \text { ACA13258.1 } & \text { Smp_048560.1 } \\ 17 & 19 & \text { XP_002582123.1 } & \text { Smp_035270.2 } \\ 18 & 18 & \text { XP_002573337.1 } & \text { Smp_018890.1 } \\ 19 & 2 & \text { XP_002572444.1 } & \text { Smp_009760.1 }\end{array}$


3 XP_002582070.1 Smp_034840.3 XP_002569974.1 Smp_092280.1 XP_002571710.1 Smp_002410.1

30 XP_002575845.1 Smp_045220.1

31 XP_002580684.1 Smp_176200.2 XP_002579290.1 Smp_082030.1 XP_002571343.1 Smp_120700.1 XP_002571573.1 Smp_200240.1

37 XP_002575979.1 Smp_046600.1 XP_002582203.1 Smp_102070.1 XP_002580559.1 Smp_096760.1 XP_002577807.1 Smp_065610.2 23 ABU49846.1 Smp_194770.1

24 XP_002571755.1 Smp_002880.1

6 XP_002569898.1 Smp_086480.1

7 XP_002569900.1 Smp_086530.1

8 XP_002580444.1 Smp_095520.1

$9 \quad$ AAR85354.1 Smp_046690.1

AAL79841.1 Smp_008070.1

12 XP_002579726.1 Smp_086330.1

$$
\text { 14-3-3 epsilon }
$$

Proteasome subunit alpha 3

$$
\text { 14-3-3 epsilon } 2
$$

Myosin light chain

$\mathrm{Cu} / \mathrm{Zn}$-superoxide dismutase

family C56 non-peptidase homologue (C56

$$
\text { family) }
$$

Cofilin, actophorin, putative

Hypothetical conserved - Usp - Universal stress protein family

$$
\text { Actin }
$$

Glutathione S-transferase $26 \mathrm{kDa}$

Phosphoglycerate mutase

Pyruvate kinase, putative

$$
\text { Creatine kinase }
$$

ATP synthase alpha subunit mitochondrial, putative

$$
\text { Sm24 }
$$

Tegumental antigen Sm20.8

$$
\text { Dynein light chain }
$$

Ubiquitin

Thioredoxin

Calponin-related

$\begin{array}{cccc}391 & 28850 & 4,85 & 48 \\ 234 & 28354 & 4,89 & 22 \\ 152 & 28756 & 5,2 & 21 \\ 67 & 18461 & 4,5 & 28 \\ 67 & 15869 & 6,08 & 41 \\ 121 & 19307 & 7,66 & 22 \\ 110 & 16001 & 6,43 & 37 \\ 72 & 91724 & 9,53 & 1 \\ 181 & 41990 & 5,3 & 17 \\ 215 & 25424 & 6,84 & 27 \\ 145 & 28579 & 7,71 & 30 \\ 143 & 55147 & 6,79 & 15 \\ 86 & 77352 & 8,08 & 10 \\ 443 & 59835 & 9,16 & 22 \\ & & & \\ 86 & 21789 & 6,85 & 27 \\ 84 & 20869 & 6,9 & 19 \\ 72 & 10450 & 6,13 & 28 \\ 85 & 11554 & 8,82 & 17 \\ 289 & 12030 & 5,84 & 64 \\ 138 & 21362 & 8,68 & 22\end{array}$

Núcleo

Citoplasma/

Núcleo

Núcleo

Citoplasma/

Núcleo

Citoplasma

Citoplasma

Citoplasma

Núcleo/

Citoplasma

Citoplasma

Citoplasma

Núcleo

Citoplasma

Mitocôndria

Mitocôndria

Citoplasma/ Núcleo

Citoplasma/ Núcleo

Citoplasma

Núcleo/

Citoplasma

Citoplasma/

Mitocôndria

Núcleo/Citoplasma
$-$ 


$\begin{array}{rrrrcrcrcr}22 & \text { CCD76164.1 } & \text { Smp_106930.1 } & \text { Antigen/hsp70 homologue } & 222 & 68331 & 5,4 & 21 & \text { Citoplasma } \\ 25 & \text { XP_002572342.1 } & \text { Smp_008660.1 } & \text { Gelsolin, putative } & 178 & 41968 & 5,57 & 23 & \text { Citoplasma } & - \\ 26 & \text { XP_002577298.1 } & \text { Smp_059980.1 } & \text { Arginase } & 298 & 40234 & 5,72 & 11 & \text { Citoplasma } & - \\ 28 & \text { XP_002570504.1 } & \text { Smp_179810.1 } & \text { Troponin t, invertebrate, putative } & 36 & 37472 & 5,89 & 4 & \text { Núcleo } \\ 29 & \text { XP_002574611.1 } & \text { Smp_031770.4 } & \text { Tropomyosin } & 70 & 32676 & 4,5 & 13 & \text { Citoesqueleto } & - \\ 32 & \text { XP_002575877.1 } & \text { Smp_045560.1 } & \text { Annexin, putative } & 108 & 37319 & 5,96 & 18 & \text { Núcleo } \\ 35 & \text { XP_002578417.1 } & \text { Smp_072330.1 } & \text { Heat shock protein, putative } & 236 & 81104 & 4,92 & 20 & \text { Citoplasma } & * \\ 38 & \text { CAZ37624.1 } & \text { Smp_106130.2 } & \text { Heat shock protein 70 (hsp70), putative } & 303 & 71595 & 6,09 & 21 & \text { Mitocôndria } & *\end{array}$

(+): proteínas upreguladas no estresse oxidativo; (*): proteínas upreguladas no estresse térmico; (\#): proteínas upreguladas nos dois tipos de estresse; (-) proteínas identificadas sem alteração de expressão. Spot O: número do spot no gel para estresse oxidativo (Figura 37) e Spot T: número do spot no gel para estresse térmico (Figura 38). 
Como podemos observar o perfil de expressão de proteínas foi modulado durante o estresse oxidativo e térmico. Através de espectrometria de massas, 47 proteínas foram identificadas tanto no estresse oxidativo como no estresse térmico. Deste total de proteínas identificadas, 23 proteínas tiveram sua expressão aumentada após estresse oxidativo e 24 proteínas foram upreguladas no estresse térmico (Tabela 6). Além disso, podemos observar que 18 proteínas foram igualmente upreguladas no estresse oxidativo e térmico (Tabela 6).

As proteínas que apresentaram aumento de expressão após o tratamento de vermes adultos de $S$. mansoni com peróxido de hidrogênio e estresse térmico podem ser divididas em cinco categorias principais, sendo elas: processos metabólicos (enzimas da via glicolítica, ciclo de Krebs, via da pentose-fosfato, síntese de ácidos graxos), proteínas associadas aos microtúbulos, proteínas de resposta ao estresse, proteínas de ligação (á íons cálcio, ATP ou outras proteínas) e proteínas regulatórias.

Dentre as proteínas relacionadas com processos metabólicos, as proteínas que tiveram sua expressão induzida foram: Enolase (Smp_024110.1), uma proteína citoplasmática de ligação a íons magnésio, Malato Desidrogenase (Smp_035270.2), a qual participa das reações do ciclo de Krebs, Triose Fosfato Isomerase (Smp_003990.1), uma proteína envolvida na síntese de ácidos graxos, glicólise, gliconeogênese e rota das pentosesfosfato, Fosfoglicerato Mutase (Smp_096760.1) e Fosfoglicerato Kinase (Smp_018890.1) envolvidas da via glicolítica, Aldeído Desidrogenase (Smp_050390.1), envolvida em processos de oxirredução e Gliceraldeído-3-Fosfato Desidrogenase (Smp_056970.1), uma proteína citoplasmática que participa da glicólise. Outra proteína de expressão induzida após os estresses foi a proteína Antigen/Calreticulin (Smp_030370.1), uma proteína presente no retículo endoplasmático que apresenta a função de ligação a íons cálcio e a proteínas desdobradas, sendo responsável pelo correto dobramento (folding) de outras proteínas. Como uma função semelhante e com um aumento de 2,07 vezes na sua expressão (estresse oxidativo), podemos citar a proteína Ciclofilina (Smp_040130.1) a qual apresenta atividade de peptidil-prolil cis-trans isomerase responsável pelo dobramento de proteínas, fazendo que estas adquiram sua estrutura terciária correta.

Em relação às proteínas ligadoras de íons cálcio foi observado um aumento na expressão das proteínas nucleares e citoplasmáticas Proteína ligadora de cálcio (Smp_005350.1), Miosina regulatória de cadeia leve (Smp_132670.1) e Miosina de cadeia leve (Smp_045220.1). Em relação às proteínas associadas aos microtúbulos observamos a indução na expressão das proteínas Tropomiosina (Smp_031770.4), a qual é uma proteína citoplasmática de ligação a actina, Alfa-tubulina (Smp_090120.1), Cadeia $\beta$ da tubulina 
(Smp_030730.1) e a cadeia leve da proteína motora associada ao movimento dos microtúbulos, Dineína (Smp_095520.1). No estresse térmico, foi possível identificar a upregulação da proteína Antígeno do tegumento Sm 20.8 (Smp_086530.1).

O estresse oxidativo e térmico também provocaram um aumento na expressão de proteínas envolvidas em mecanismos de resposta ao estresse. No estresse oxidativo, observamos a upregulação das proteínas Glutationa S-Transferase (28k) (Smp_054160.1), Glutationa S-Transferase (26k) (Smp_102070.1) e Thioredoxin (Smp_008070.1). Por outro lado, as proteínas Superóxido dismutase (Smp_176200.2), Glutationa S-Transferase (28k) (Smp_054160.1), assim como duas isoformas da proteína de resposta a estresse térmico HSP70 (Smp_072330.1 e Smp_106130.2) foram upreguladas. Muitas vias parecem estar alteradas após indução de estresse oxidativo. Foi observado um aumento na expressão da proteína alfa-3 (Smp_092280.1), uma proteína citoplasmática e nuclear que faz parte da subunidade $20 \mathrm{~S}$ do proteassoma e está envolvida em processos catabólicos dependentes de ubiquitina. A proteína nuclear regulatória 14-3-3 epsilon 2 (Smp_002410.1) apresenta função de ligação a outras proteínas podendo desta forma controlar diversas vias de sinalização, e foi também upregulada após estresse oxidativo. A proteína Ubiquitina (Smp_046690.1) importante em processos de ubiquitinação teve sua expressão alterada 1,16 vezes após o estresse térmico.

Por fim, no estresse oxidativo e térmico foi observado um aumento na expressão da proteína Creatina kinase (Smp_194770.1), na proteína ATP sintase mitocondrial (subunidade alfa) (Smp_002880.1), na proteína Limpetin (Smp_048560.1) e as proteínas Gelsolin (Smp_008660.1), Troponin t (Smp_ 179810.1) e uma isoforma de Tropomiosina (Smp_031770.4), Arginase (Smp_059980.1) e Annexin (Smp_045560.1), foram expressas após estresse térmico em vermes adultos.

Na tabela 7 são mostradas as proteínas que foram upreguladas na condição de estresse oxidativo e no estresse térmico bem como o número de vezes (Fold change) de aumento na sua expressão. Este parâmetro foi calculado dividindo a área do spot no gel tratado pela área do spot correspondente no gel controle, sendo consideradas com upreguladas as proteínas com fold change $>1$. 
Tabela 7. Proteínas upreguladas no estresse oxidativo e térmico e Fold change da expressão proteica.

\begin{tabular}{|c|c|c|c|}
\hline \multicolumn{4}{|c|}{ Estresse Oxidativo } \\
\hline Spot & Gene Smp & Proteína & Fold change \\
\hline 1 & Smp_030370.1 & Antigen/Calreticulin & 2,02 \\
\hline 2 & Smp_031770.4 & Tropomyosin & 3,55 \\
\hline 3 & Smp_030730.1 & Tubulin beta chain, putative & 2,2 \\
\hline 4 & Smp_090120.1 & Alpha tubulin & 1,49 \\
\hline 5 & Smp_050390.1 & Aldehyde dehydrogenase, putative & 3,43 \\
\hline 6 & Smp_024110.1 & Enolase & 1,29 \\
\hline 7 & Smp_005350.1 & Calcium binding protein & 2,8 \\
\hline 8 & Smp_132670.1 & Myosin regulatory light chain, putative & 3,65 \\
\hline 10 & Smp_040130.1 & Cyclophilin & 2,07 \\
\hline 11 & Smp_054160.1 & $28 \mathrm{k}$ antigen & 1,02 \\
\hline 12 & Smp_003990.1 & Triose phosphate isomerase & 1,02 \\
\hline 13 & Smp_096760.1 & Phosphoglycerate mutase & 2,7 \\
\hline 15 & Smp_056970.1 & Glyceraldehyde-3-phosphate dehydrogenase & 2,58 \\
\hline 16 & Smp_048560.1 & Limpetin & 1,57 \\
\hline 17 & Smp_035270.2 & Malate dehydrogenase, putative & 2,16 \\
\hline 21 & Smp_092280.1 & Proteasome subunit alpha 3 (T01 family) & 1,82 \\
\hline 22 & Smp_002410.1 & 14-3-3 epsilon 2 & 1,32 \\
\hline 23 & Smp_045220.1 & Myosin light chain & 2,25 \\
\hline 29 & Smp_102070.1 & Glutathione S-transferase $26 \mathrm{kDa}$ & 1,35 \\
\hline 32 & Smp_194770.1 & Creatine kinase & 2,66 \\
\hline 33 & Smp_002880.1 & ATP synthase alpha subunit mitochondrial, putative & 1,2 \\
\hline 36 & Smp_095520.1 & Dynein light chain & 1,15 \\
\hline 38 & Smp_008070.1 & Thioredoxin & 1,60 \\
\hline \multicolumn{4}{|c|}{ Estresse Térmico } \\
\hline Spot & Gene Smp & Proteína & Fold change \\
\hline 1 & Smp_030370.1 & Antigen/Calreticulin & 1,75 \\
\hline 4 & Smp_005350.1 & Calcium binding protein & 1,93 \\
\hline 5 & Smp_031770.4 & Tropomyosin & 1,89 \\
\hline 7 & Smp_086530.1 & Tegumental antigen Sm20.8 & 1,96 \\
\hline 8 & Smp_095520.1 & Dynein light chain & 1,75 \\
\hline 9 & Smp_046690.1 & Ubiquitin & 1,16 \\
\hline 10 & Smp_054160.1 & $28 \mathrm{~K}$ antigen & 1,32 \\
\hline 11 & Smp_040130.1 & Cyclophilin & 1,23 \\
\hline 13 & Smp_056970.1 & Glyceraldehyde-3-phosphate dehydrogenase & 1,05 \\
\hline 14 & Smp_048560.1 & Limpetin & 1,64 \\
\hline 17 & Smp_096760.1 & Phosphoglycerate mutase & 2,41 \\
\hline 18 & Smp_018890.1 & Phosphoglycerate kinase & 1,40 \\
\hline 19 & Smp_035270.2 & Malate dehydrogenase, putative & 1,67 \\
\hline
\end{tabular}


20 Smp_024110.1

21 Smp_050390.1

23 Smp_194770.1

24 Smp_002880.1

27 Smp_132670.1

30 Smp_045220.1

31 Smp_176200.2

33 Smp_030730.1

34 Smp_090120.1

35 Smp_072330.1

38 Smp_106130.2
Enolase

1,21

Aldehyde dehydrogenase, putative

1,44

Creatine kinase

1,15

ATP synthase alpha subunit mitochondrial, putative

1,01

Myosin regulatory light chain, putative

1,03

Myosin light chain

1,02

$\mathrm{Cu} / \mathrm{Zn}$-superoxide dismutase

1,33

Tubulin beta chain, putative

1,78

Alpha tubulin

1,98

Heat shock protein, putative

1,78

Heat shock protein 70 (hsp70), putative

\subsection{Categorização das proteínas diferencialmente expressas}

\subsubsection{Estresse oxidativo}

O programa Blast2GO foi utilizado para obter as ontologias para as proteínas diferencialmente expressas oriundas do processo de estresse oxidativo. As proteínas foram agrupadas de acordo com o segundo nível de hierarquia do Gene Ontology (GO) sendo identificadas com termos GO nas classificações: Processo Biológico, Função Molecular e Componente Celular.

Quanto à categoria de Processo Biológico, podemos observar na figura 39 que $32 \%$ das proteínas estão envolvidas com processos celulares, $27 \%$ com processos metabólicos, $6 \%$ com processos de desenvolvimento, $4 \%$ com processos de multi-organismos, $2 \%$ com processos de crescimento, $9 \%$ com componentes de organização celular, $2 \%$ com resposta a estímulo, $4 \%$ com regulação biológica, $6 \%$ com processos de biogênese de componentes celulares, $2 \%$ com processos reprodutivos e $2 \%$ com sinalização, proliferação e localização celular. 


\section{Processo Biológico}

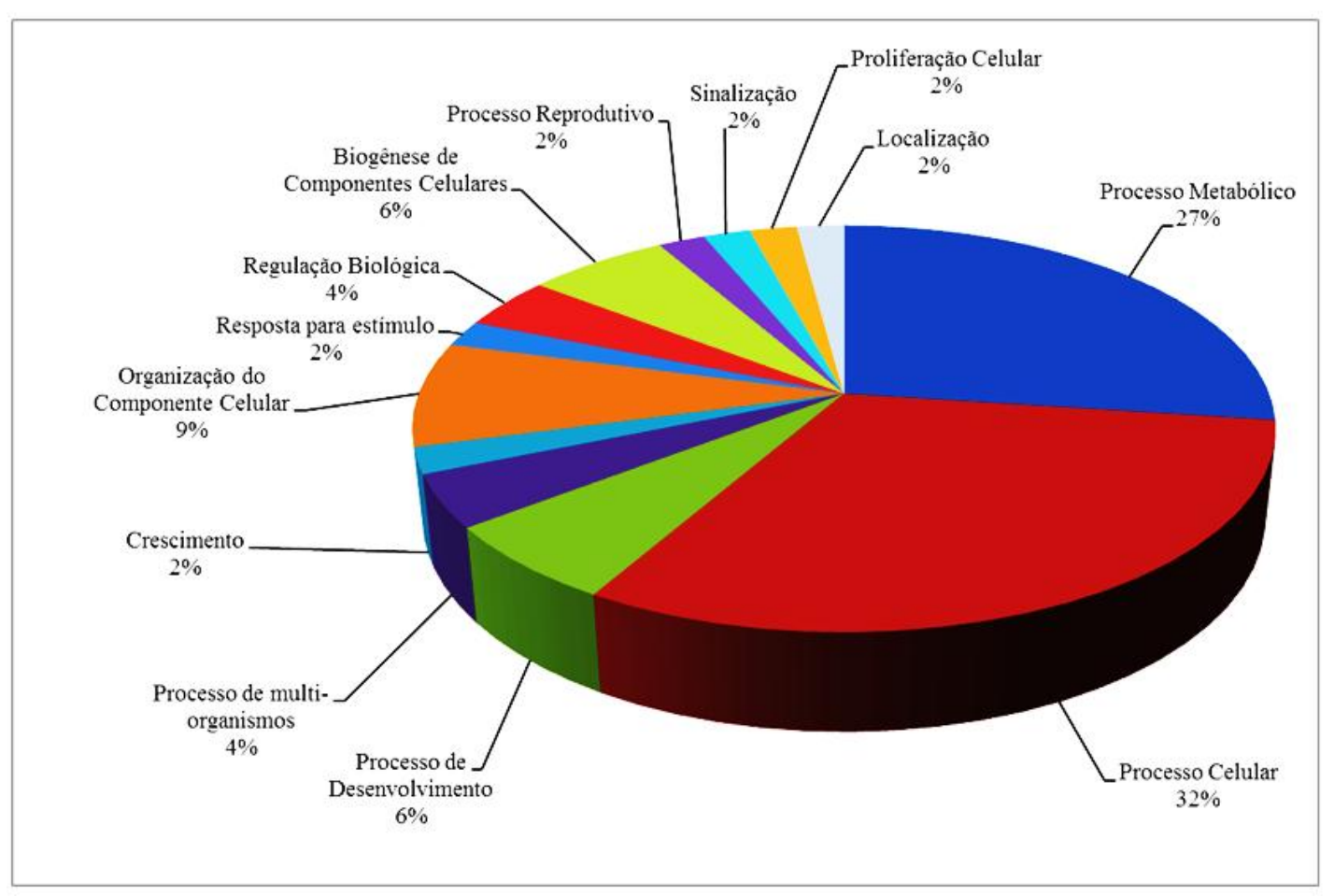

Figura 39. Categorização das proteínas diferencialmente expressas no estresse oxidativo quanto a Processos Biológicos. Termos de Gene Ontology (GO) foram atribuídos as proteínas usando nível 2 de anotação do Blast2GO.

Quando as proteínas foram categorizadas quanto à Função Molecular, foi possível observar que $41 \%$ das proteínas estão envolvidas em funções de ligação, seja a outras proteínas ou íons, $47 \%$ das proteínas estão envolvidas com atividades catalíticas, $6 \%$ com atividade Estrutural, 3\% com atividade regulatória de enzimas e 3\% com atividade de transporte (Figura 40). Finalmente, quanto a Componentes celulares, observamos que $41 \%$ das proteínas são componentes intracelulares, $24 \%$ compõem complexos macromoleculares, $26 \%$ estão em organelas, $6 \%$ das proteínas encontram-se no lúmen de membranas e 3\% localizam-se em regiões extracelulares (Figura 41). 


\section{Função Molecular}

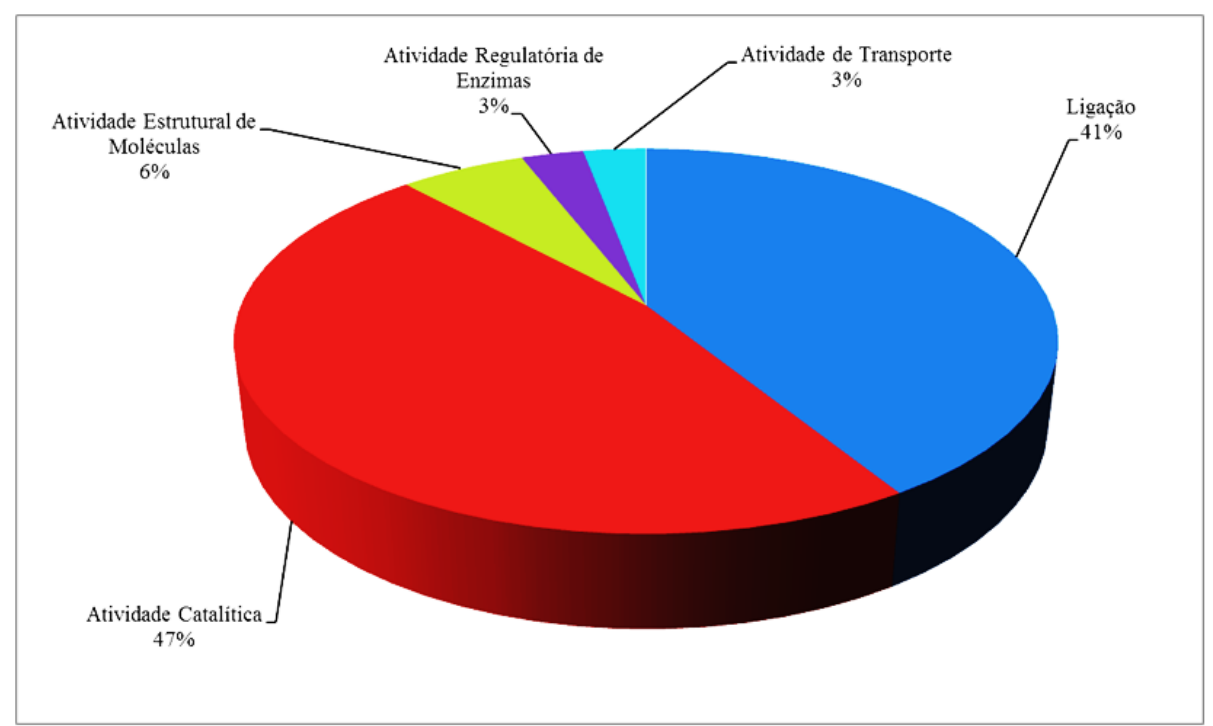

Figura 40. Categorização das proteínas diferencialmente expressas no estresse oxidativo quanto a Função Molecular. Termos de Gene Ontology (GO) foram atribuídos as proteínas usando nível 2 de anotação do Blast2GO.

\section{Componente Celular}

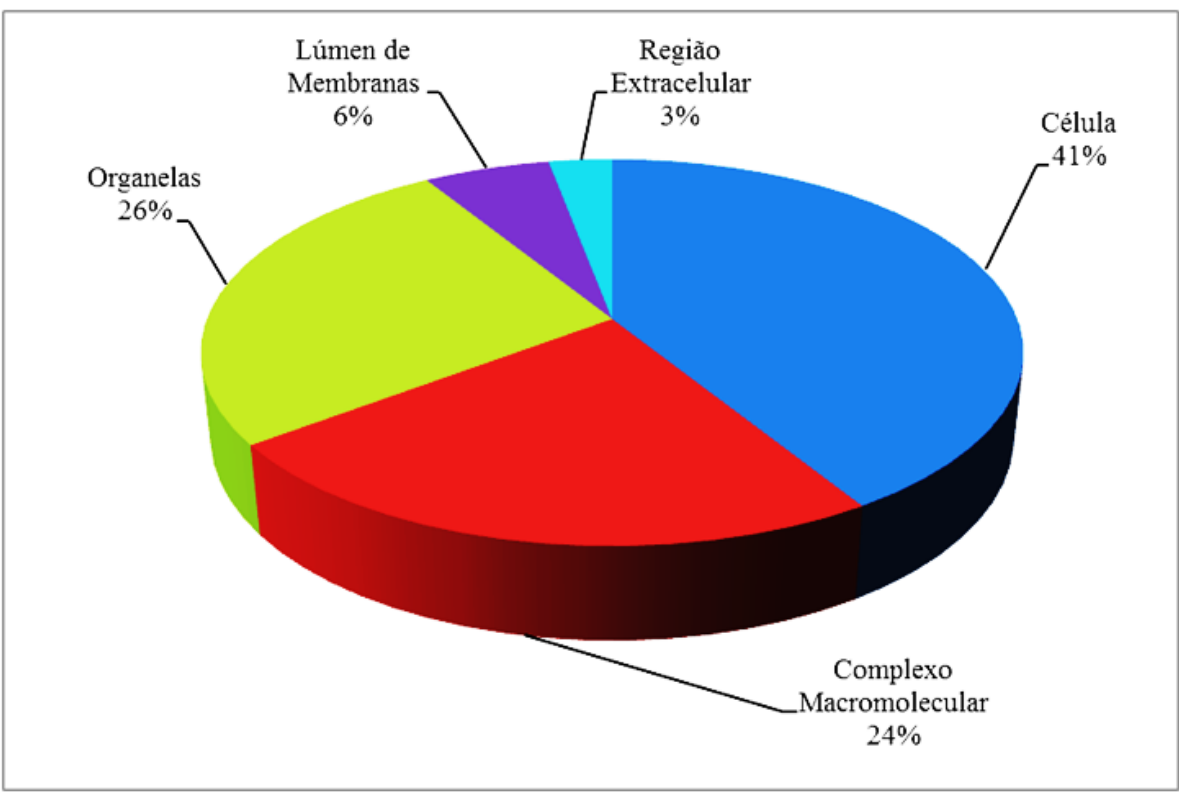

Figura 41. Categorização das proteínas diferencialmente expressas na condição de estresse oxidativo quanto a Componente Celular. Termos de Gene Ontology (GO) foram atribuídos as proteínas usando nível 2 de anotação do Blast2GO. 


\subsubsection{Estresse térmico}

Podemos observar na figura 42 que $38 \%$ das proteínas estão envolvidas com processos celulares, $35 \%$ com processos metabólicos, 6\% com processos de desenvolvimento, 3\% com processos de multi-organismos, $9 \%$ com componentes de organização celular e biogênese, 3\% com regulação biológica e 3\% em proliferação e localização celular. Além disso, $46 \%$ e $43 \%$ das proteínas estão envolvidas em processos de ligação e atividade catalítica, respectivamente. Quanto ao componente celular, observamos que $39 \%$ das proteínas são componentes intracelulares e $25 \%$ encontram-se em organelas.

A

\section{Processo Biológico}

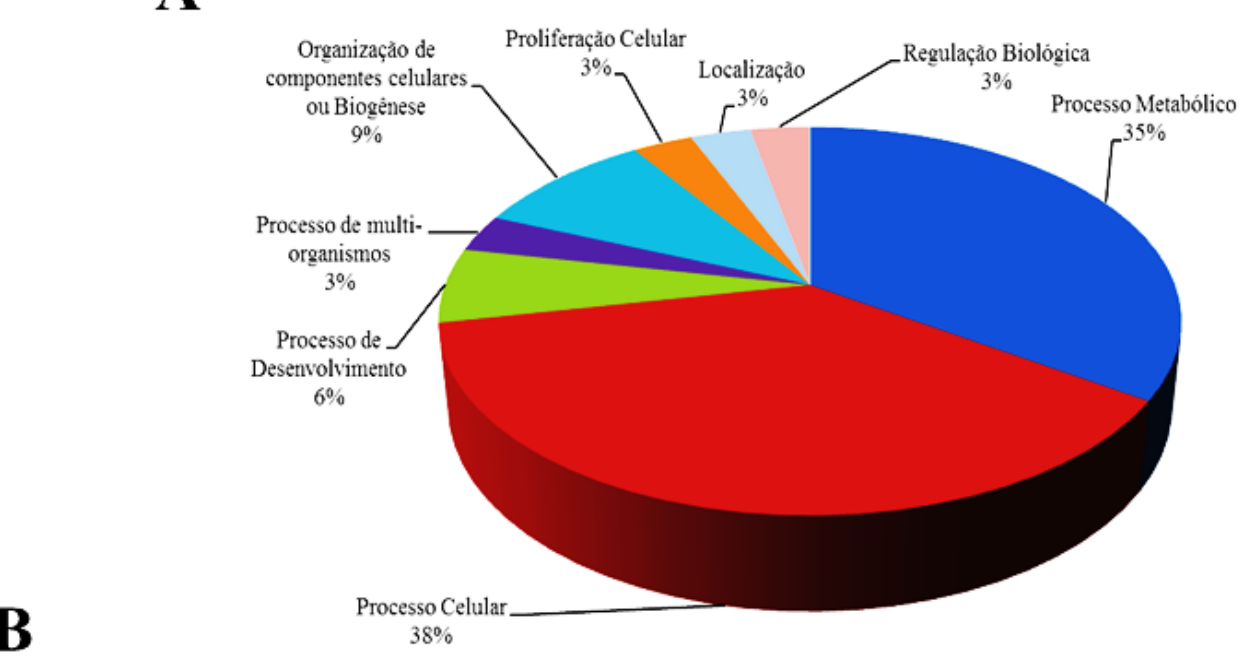

C
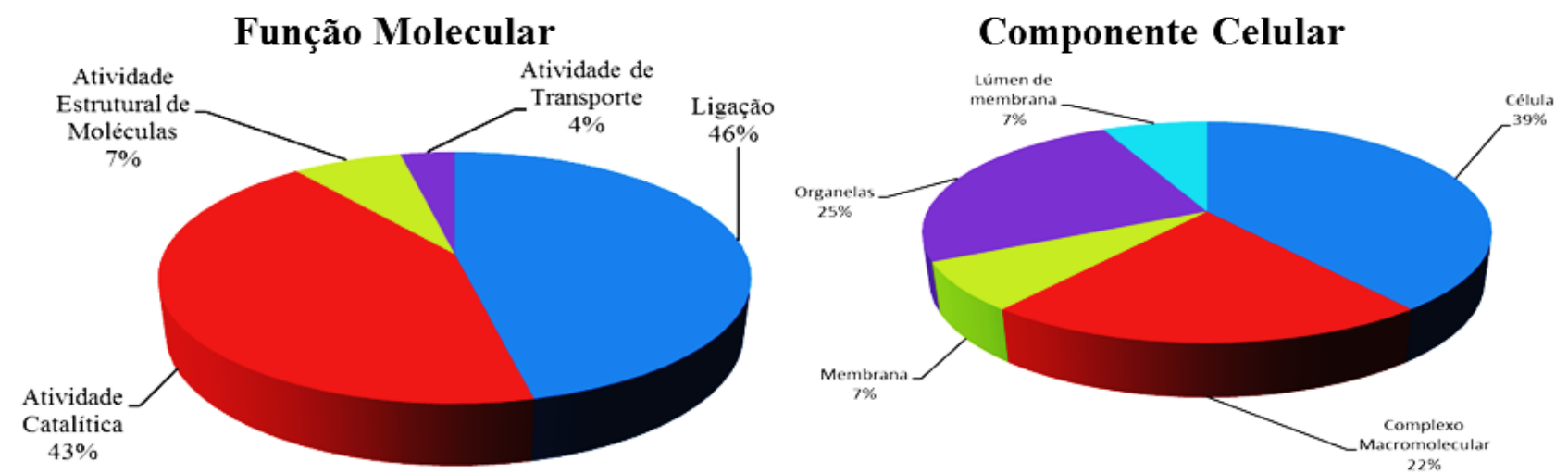

Figura 42. Categorização das proteínas diferencialmente expressas na condição de estresse térmico. Termos de Gene Ontology (GO) foram atribuídos as proteínas usando nível 2 de anotação do Blast2GO. (A) Processo Biológico, (B) Função Molecular e (C) Componente Celular. 
5. Discussão 


\section{Discussão}

\subsection{Caracterização dos genes $\mathrm{SmHul5}$ e SmUbp6}

O sistema proteolítico ubiquitina-proteassoma é formado pela partícula central $20 \mathrm{~S}$ e um conjunto de outras proteínas regulatórias que controlam a sua atividade e especificidade (JUNG et al., 2009). Este complexo sistema é uma nanomáquina que controla a degradação de proteínas relacionadas a diversos processos celulares, como o controle do ciclo celular, resposta ao estresse, expressão gênica, "controle de qualidade" de proteínas, resposta imune, reparo do DNA e carcinogênese (DAVIES, 2001; NAUJOKAT et al., 2007; CSIZMADIA et al., 2010). O proteassoma 20S é um componente essencial e altamente conservado tanto em eucariotos (plantas e animais) como em procariotos fundamental do sistema proteassomal. A partícula 20S é formada pelos anéis alfa (externos) e beta (internos), sendo as subunidades $\beta 1, \beta 2$ e $\beta 5$ os núcleos catalíticos do proteassoma (LOIDL et al., 1999; GROLL; HUBER, 2004).

Este sistema proteolítico é importante para manter para manter a homeostase proteica durante o estresse celular (MAYER, 2010; TOIVOLA et al., 2010), e pode associar-se transitoriamente com proteínas acessórias. Muitas proteínas acessórias tem sido descritas como reguladoras da atividade e da taxa de degradação proteica pelo proteassoma $20 \mathrm{~S}$ (PICKET, 2007). A enzima deubiquitinadora Ubp6 encontra-se associada à base do complexo 19S (HANNA et al., 2006) e promove o recrutamento de moléculas de ubiquitina a partir de substratos proteicos (FINLEY, 2009), regulando desta forma a degradação do substrato pelo proteassoma. Em S. cerevisiae a enzima ubiquitina ligase Hul5 é a principal proteína associada ao proteassoma responsável por estender as cadeias de multiubiquitina nos substratos proteicos e, portanto, promovendo a sua ativação (ZHANG, 2009).

Borodovsky e colaboradores (2002) relataram a associação da partícula 19S com enzimas deubiquitinadoras (DBUS) ativas, tornando esta classe de enzimas importantes reguladores do sistema ubiquitina-proteassoma. Esta grande família de proteínas tem sido identificada em uma variedade de organismos e parecem regular uma série de processos biológicos (KIM et al., 2003; TSE et al., 2011; BURROWS; JOHNSTON, 2012). Trabalhos recentes em leveduras tem mostrado que a deleção de Ubp6 interfere no processo de montagem da partícula 19S (SAKATA et al., 2011), sugerindo que esta proteína é fundamental no processo de organização do proteassoma e consequentemente para sua função. 
Nossos resultados de bioinformática permitiram a identificação da sequência homóloga para Ubp6 em Schistosoma mansoni (SmUbp6). Esta proteína apresenta um domínio UCH característico de uma classe de enzimas deubiquitinadoras e é altamente conservada entre os organismos sugerindo uma conservação estrutural e funcional. A sequência de SmUbp6 apresentou uma identidade de $84 \%$ com a proteína de S. japonicum demonstrando uma alta similaridade interespecífica. A organização estrutural de SmUbp6 revelou que este gene apresenta um processo de splicing altamente conservado, sendo o transcrito para esta proteína oriundo de 6 éxons.

Esse gene é expresso nas fases de esquistossômulos, vermes adultos (casal, machos e fêmeas), ovo, esporocistos, miracídios e não apresenta expressão na fase de cercária. Além disso, observamos a expressão diferencial desse gene nas fases evolutivas, sendo a expressão relativamente alta nas fases de miracídios, esporocistos e esquistossômulos. Os miracídios apresentam mecanismos específicos que permitem sua penetração no hospedeiro. Uma vez em contato com o molusco, os miracídios aderem-se e penetram neles através das secreções glandulares da papila apical (terebratorium) e movimentos rotatórios. Desta forma, os miracídios que penetraram em seu hospedeiro necessitam de rápidas modelações estruturais que culminam com a perda de seu revestimento epitelial ciliado e demais estruturas externas (órgãos de penetração) (MACHADO-SILVA et al., 2008).

Os esporocistos, por sua vez, apresentam grande quantidade de mitocôndrias, ribossomos e retículo endoplasmático, sustentando a evidência de síntese proteica e elevada atividade metabólica, consistentes com as mudanças adaptativas que ocorrem nesta fase. Segundo Burrows e Johnston (2012) as enzimas deubiquitinadoras podem estar relacionadas com diversos processos, como por exemplo, de reciclagem da membrana plasmática. A transição de cercárias para esquistossômulos é marcada por profundas mudanças bioquímicas e morfológicas que envolvem respiração anaeróbica, perda da cauda, eliminação progressiva do glicocálix, esvaziamento de glândulas secretoras e reorganização do tegumento, com marcado acúmulo da proteína transportadora de glicose (SGTP4) (SKELLY; SHOEMAKER, 2000). Deste modo, a alta expressão de SmUbp6 na fase de miracídio, esporocistos e esquistossômulos pode estar relacionada com a alta taxa de turnover de membranas e com regulação da degradação de proteínas estágio-específicas via proteassoma, modificações necessárias para permitir a progressão do ciclo celular e desenvolvimento das fases larvais.

Fang e Mayor (2012) identificaram recentemente que a enzima ligase de ubiquitina Hul5 desempenha um importante papel na via de controle de qualidade de proteínas. Estes 
autores relataram a importância desta enzima para a adaptação das células e aumento da ubiquitinação de proteínas de baixa solubilidade após choque térmico em leveduras. Aviram e Kornitzer (2010) demonstraram que Hul5 é responsável pela poliubiquitinação de proteínas específicas, controlando desta forma a processividade do proteassoma. Em $S$. mansoni a sequência homóloga para Hul5 foi recuperada do banco de dados schistodb.net com o número de acesso Smp_130650 e observamos que este gene é expresso em todas as fases de desenvolvimento do parasito menos na fase de cercária. Além disso, o nível de transcrito para $S m H u l 5$ é alto para as fases de esporocisto e esquistossômulos ( $2 \mathrm{~h}, 4 \mathrm{~h}$ e $6 \mathrm{~h}$ ).

Da mesma maneira que para $S m U p b 6$, a alta expressão de $S m H u l 5$ nas fases de esporocisto e esquistossômulos pode ser explicada pelo aumento na síntese proteica e remodelamento bioquímico e morfológico necessário para o desenvolvimento intrahospedeiro. O elevado nível de expressão de SmHul5 e SmUbp6 pode indicar um mecanismo de regulação do proteassoma nas fases larvais que é importante para o desenvolvimento do parasito. Esta evidência esta de acordo com resultados recentes sugerindo que o proteassoma está sujeito a modos de regulação subunidades específicos que servem para regular sua função e podem geram conjuntos de proteassomas com composições distintas de acordo com as condições da célula (HANNA; FINLEY, 2007; TAI et al., 2010).

\subsection{Perfil de expressão de SmHul5 e SmUbp6 após estresse químico, oxidativo e térmico}

O nível de expressão dos genes SmHul5 e SmUbp6 foram diferentemente modulados diante dos estresses químico, oxidativo e térmico. Como observado incialmente, estes genes apresentam um nível de expressão relativamente alto após 48 horas de cultivo in vitro e são expressos em todas as fases do ciclo de vida de S. mansoni, exceto na fase de cercária.

O estresse químico com IBMX provocou uma diminuição na expressão de $\mathrm{SmHul5}$ após 48 horas e 72 horas de cultivo in vitro nas concentrações de $80 \mu \mathrm{M}$ e $200 \mu \mathrm{M}$, sendo essa diminuição cerca de 5 vezes e 16 vezes menor em relação ao controle, respectivamente. Por outro lado, o gene SmUbp6 apresentou uma diminuição em sua expressão cerca de 3 vezes (IBMX $80 \mu \mathrm{M} 48$ horas) e aproximadamente 7 vezes (IBMX $200 \mu \mathrm{M}$ 48horas) e 9 vezes (IBMX $200 \mu \mathrm{M} 72$ horas) em relação ao controle. Além disso, a expressão de SmUbp6 após tratamento por 72 horas com $80 \mu \mathrm{M}$ de IBMX exibiu níveis similares ao controle. Deste modo, observamos que ambos os genes relacionados a sistema ubiquitinaproteassoma são diferentemente modulados diante de estresse químico com IBMX. 
Conforme descrito por Moreira (2008), IBMX inibi a atividade do proteassoma de $S$. mansoni, sendo esta inibição avaliada pelo aumento de proteínas poliubiquitinadas em extratos proteicos totais de vermes adultos do parasito. Além disso, foi sugerido que essa redução da atividade do proteassoma, é devido a desmontagem do complexo proteolítico, indiretamente mostrada pelo aumento da expressão da proteína de maturação do proteassoma $(S m P O M P)$ bem como pela diminuição nos níveis das subunidades $\alpha$ do proteassoma 20S. A diminuição na expressão de SmHul5 observada neste trabalho, pode estar relacionada com a inibição da atividade do proteassoma e pela diminuição no conteúdo proteico de proteassoma 20S, o que resulta em regulação ao nível transcricional levando a uma redução da transcrição deste gene e consequentemente diminuição em seu conteúdo proteico. Em adição, a desmontagem das populações de proteassoma podem também explicar a diminuição da expressão deste gene, uma vez que não está ocorrendo síntese proteica de novas populações de proteassoma.

O perfil de expressão do gene SmUbp6 também apresentou diminuição após estresse com IBMX. Esta proteína é uma enzima deubiquitinadora associada ao proteassoma responsável por regular os níveis intracelulares de ubiquitina na célula (KRAUT et al., 2007). Segundo Hanna e colaboradores (2007) a up-regulação de Ubp6 resulta em uma grande quantidade de proteassoma contendo esta enzima, fato este que aumenta a eficiência do proteassoma em reciclar ubiquitina. Diante dos nossos resultados, sugerimos que a diminuição na expressão de SmUbp6 após estresse com IBMX diminui a quantidade de proteassomas contendo a proteína Ubp6 associada, o que por sua vez influencia o processo de reciclagem das moléculas de ubiquitina a partir dos conjugados poliubiquitinados resultantes da inibição do proteassoma, o que favorece o acúmulo de proteínas poliubiquitinadas. Deste modo, a ausência de proteassomas com Ubp6 associada favorece positivamente o processo de degradação do substrato proteico o qual não ocorre devido a inibição do proteassoma provocada pelo tratamento com IBMX. Sendo assim, a diminuição da expressão deste gene parece ser regulada negativamente pela inibição do proteassoma.

Para analisar se a diminuição na expressão dos genes SmHul5 e SmUbp6 é devido a inibição do proteassoma, nós analisamos a expressão destes dois genes após estresse com MG132, um composto inibidor da atividade do proteassoma. Nossos resultados, curiosamente, revelaram um aumento na expressão dos dois genes após tratamento com 50 $\mu$ M de MG132 por 24 e 48 horas (para SmHul5) e 48, 72 e 120 horas (para SmUbp6). Além disso, podemos observar um aumento na expressão de SmPOMP após 48, 72 e 120 horas de tratamento com mesma concentração do composto MG132. O aumento na expressão da 
proteína SmPOMP possivelmente está relacionado com a síntese de novas populações de proteassoma, uma vez que temos também um aumento na expressão de SmHul5 e SmUbp6 os quais possivelmente são necessários para organização de novas subpopulações de proteassoma em resposta ao estresse com MG132. A expressão de SmPOMP mostrou-se aumentada tanto no tratamento com IBMX quanto com MG132, no entanto, no tratamento com IBMX existe evidência de que o aumento na expressão deste gene esteja relacionado a desmontagem do proteassoma (MOREIRA, 2008) enquanto que no tratamento com MG132, este aumento pode relacionar-se a montagem de novas populações de proteassoma, evidência esta suportada pelo aumento na expressão das proteínas acessórias SmHul5 e SmUbp6 observado neste tratamento após estresse químico com MG132.

Deste modo, nossos resultados estão de acordo com Morais (2012) e sugerem que a maquinaria de expressão gênica dos parasitos responde a inibição pelo MG132 produz mais populações de proteassoma. Neste trabalho, os autores demonstraram por análises de microarray a indução na expressão de genes relacionados ao proteassoma $26 \mathrm{~S}$ e também repressão na expressão de genes relacionados a montagem da partícula 19S e 20S, sugerindo que a recuperação da atividade proteolítica não consegue ser normalizada acarretando em danos celulares ao parasito. Sendo assim, analisando o perfil de expressão de SmHul5 e SmUbp6 após estresse químico com IBMX e MG132, sugerimos que a expressão destes genes parece ser regulada de maneira diferente, o que sugere mecanismos de ação diferente entre os dois compostos.

O composto Curcumina oriundo da planta Curcuma longa tem demonstrado resultados promissores em estudos in vitro com S. mansoni. Magalhaes (2009) demonstrou que Curcumina nas concentrações de 20, 50 e $100 \mu \mathrm{M}$ provoca separação casais de vermes adultos após 24 horas de cultivo e 100\% de mortalidade após 120 horas nas concentrações de 50 e $100 \mu \mathrm{M}$. Além disso, em concentrações menores (5 a $20 \mu \mathrm{M})$ foi observada diminuição da atividade motora dos parasitos bem como uma redução significativa no número de ovos. Recentemente, vários trabalhos demonstraram a eficácia do composto Curcumina contra muitos parasitos como: Angiostrongylus cantonensis, Giardia lamblia e Trypanosoma (PÉREZ-ARRIAGA, et al. 2006; SHIH et al., 2007; NAGAJYOTHI et al., 2012). El-Agamy e colaboradores (2011) demonstram que Curcumina exibe uma potente atividade anti-fibrótica, promovendo ao mesmo tempo uma repressão e reversão da fibrose hepática induzida por S. mansoni. Morais e colaboradores (2013) descrevem a alteração na expressão de genes relacionados com as vias TGF- $\beta$ e Notch em vermes adultos de $S$. mansoni após tratamento com Curcumina e sugerem que esta alteração possa explicar efeitos 
como a diminuição na ovoposição e desenvolvimento de ovos observados após tratamento com Curcumina.

Muitos autores têm relatado a possível influência deste composto sobre o proteassoma 20S (HATCHER et al., 2008; MAGALHAES et al., 2009). Jana e colaboradores (2004) demonstraram que a exposição de células neuro2a de camundongos a Curcumina causa um decréscimo na atividade do proteassoma, aumento na acumulação de proteínas ubiquitinadas e ativação de uma via de apoptose mitocondrial. Dikshit e colaboradores (2006) demonstraram que Curcumina inibe diretamente atividade enzimática do proteassoma 20S, sendo a falha na função proteassomal responsável por induzir resposta ao estresse e reprimir a ativação de NF-אB. Si e colaboradores (2007) demonstraram que células HeLa tratadas com Curcumina apresentam tanto uma redução na atividade catalítica da partícula 20S quanto na atividade de deubiquitação da célula, o que acarreta na acumulação de proteínas ubiquitinadas e decréscimo no nível de ubiquitina livre. O tratamento de linhagens celulares de câncer de cólon humano com Curcumina promoveu a inibição da atividade do proteassoma gerando o acúmulo de proteínas alvo de degradação pelo proteassoma e subsequente indução de apoptose (MILACIC et al., 2008).

O tratamento de vermes adultos de $S$. mansoni com 5 e $10 \mu \mathrm{M}$ de Curcumina por 24 horas alterou o perfil de expressão de genes relacionados ao sistema ubiquitina-proteassoma. Nossos resultados mostraram um aumento de cerca de 4 vezes na expressão de SmHul5 e 13 vezes na expressão do gene SmUbp6 após tratamento com 5 e $10 \mu \mathrm{M}$ (para SmHul5) e 10 $\mu \mathrm{M}$ (para SmUbp6). Além disso, observamos um aumento na expressão de SmPOMP após tratamento com as duas concentrações de Curcumina. Diante destes resultados, sugerimos que Curcumina inibe a atividade do proteassoma de vermes adultos de S. mansoni e como medida compensatória ocorre indução da síntese novas populações de proteassoma, o que explica a aumento na expressão das enzimas acessórias do proteassoma (SmHul5 e SmUbp6) e da proteína de maturação do proteassoma (SmPOMP). Além disso, o aumento de 13 vezes na expressão da enzima deuquitinadora SmUbp6 sugere que Curcumina interfere também com a atividade de deubiquitinação da célula. Neste caso, o aumento na expressão da enzima deubiquitinadora estaria relacionado ao recrutamento das moléculas de ubiquitina a partir dos conjugados proteicos poliubiquitinados acumulados devido à inibição do proteassoma em resposta ao tratamento com Curcumina. Esta evidência está de acordo com os resultados demonstrados por Si e colaboradores (2007).

A via ubiquitina-proteassoma é alterada mediante condição de estresse oxidativo. A exposição de células endoteliais da retina para concentrações fisiológicas de peróxido de 
hidrogênio levou a um aumento na atividade do sistema ubiquitina proteassoma e bem como aumento no turnover de conjugados de ubiquitina (FERNANDES et al., 2006). A formação de proteínas oxidadas é uma das principais alterações durante o estresse oxidativo (JUNG et al., 2007). Para manter o seu funcionamento e integridade a célula possui sistemas capazes de reconhecer e degradar proteínas danificadas ou dobradas incorretamente de forma rápida e eficiente, prevenindo a sua agregação (GRUNE et al., 2004). O sistema ubiquitinaproteassoma tem sido caracterizado como principal sistema responsável pela degradação de proteínas oxidadas (BADER; GRUNE, 2006; JUNG et al., 2007). Silva (2009) demonstrou um perfil semelhante entre a atividade do proteassoma $20 \mathrm{~S}$ e $26 \mathrm{~S}$ em vermes adultos de $S$. mansoni após $5 \mathrm{~h}$ de estresse oxidativo com peróxido de hidrogênio. Shringarpure e colaboradores (2003) descrevem a independência da conjugação de ubiquitina para a degradação de proteínas oxidadas, sugerindo que a degradação dessas proteínas é medida de maneira ATP independente pelo proteassoma 20S. Corroborando com esta hipótese, Costa e colaboradores (2007) observaram um aumento na expressão de genes que codificam para diversas subunidades que compõem o centro $20 \mathrm{~S}$.

Nossos resultados, apontam para um aumento na expressão dos genes $\mathrm{SmHul5}$ e SmUbp6 durante o estresse oxidativo. Foi observado, para o gene SmHul5, um aumento na expressão a partir de 30 minutos sendo este aumento mantido após 1 hora e 24 horas de estresse oxidativo. Já o gene SmUbp6 teve sua expressão aumentada após 1 hora de tratamento e apresentou um pico máximo de expressão após 24 horas de tratamento. Além disso, observamos que o perfil de expressão de SmPOMP apresentou um aumento de 2 a 3 vezes após 30 minutos e 1 hora, respectivamente. Estes resultados sugerem que durante condição de estresse oxidativo em vermes adultos de $S$. mansoni, ocorre à síntese de novas populações de proteassoma conforme demonstrado pelo aumento na expressão de subunidades do proteassoma e também pelo aumento da proteína de maturação do proteassoma. Corroborando com estes resultados, a análise western blotting revelou um aumento do conteúdo proteico de proteassoma 20S após 30 minutos, 1 hora, 4 horas e 24 horas de indução de estresse oxidativo, sugerindo que está ocorrendo uma intensa síntese de novas partículas 20S necessárias para organização de novas populações de proteassoma durante a resposta ao estresse oxidativo. Esta hipótese pode ser reforçada também pelo aumento na expressão da proteína alfa-3 (subunidade do proteassoma) observada em nossos resultados de proteoma. Sendo assim, sugerimos a síntese de novas partículas $20 \mathrm{~S}$ e também que a degradação das proteínas modificadas durante o estresse oxidativo de vermes de $S$. mansoni seja realizada através do proteassoma 20 S. 
Chondrogianni e Gonos (2007) demonstraram que a overexpressão de hUMP1/POMP (homólogo humano da proteína de maturação do proteassoma) em fibroblastos está relacionada com um aumento nos níveis de montagem e funcionalidade do proteassoma bem como com a capacidade de responder de forma rápida e eficaz ao estresse oxidativo. Estes resultados corroboram com o aumento de expressão do gene SmPOMP observado em nosso trabalho, o qual pode, da mesma forma, estar relacionado com a montagem de novas populações de proteassoma e com a resposta ao estresse oxidativo.

Fujimuro e colaboradores (1997) demonstraram um acúmulo de proteínas multiubiquitinadas após estresse térmico $\left(42^{\circ} \mathrm{C}-44^{\circ} \mathrm{C}\right)$ por 30 minutos em células HeLa, sendo a acumulação das proteínas multiubiquitinadas aumentada com a elevação na temperatura. Além disso, foi demonstrado que o aumento da temperatura aparentemente não altera a atividade do proteassoma 26S e induz a atividade do sistema de ubiquitinação da célula. Fang e colaboradores (2011) demonstram, em leveduras, que o choque térmico induz um aumento na ubiquitinação de proteínas citoplasmáticas mal-dobradas e que Hul5 é requerida para a manutenção da viabilidade celular e degradação de proteínas citosólicas de vida curta modificadas após choque térmico. Além disso, foi sugerido que esta enzima está envolvida na ubiquitinação de proteínas citosólicas de baixa solubilidade. Os mecanismos pelos quais Hul5 medeia o aumento na ubiquitinação após choque térmico e como reconhece as proteínas mal-dobradas permanecem não esclarecidos (FINLEY, 2011). No entanto, foi recentemente demonstrado que Hul5 é recrutada para o proteassoma em diversas condições de estresse, inclusive no estresse térmico (PARK et al., 2011). Fang e Mayor (2012) sugerem que diferentes vias do controle de qualidade proteínas podem direcionar a degradação de proteínas citosólicas deformadas e que a enzima Hul5 é fundamental para o funcionamento da via de degradação de proteínas alteradas após estresse térmico.

Moreira (2008) demonstrou que mediante condições de estresse térmico $\left(25^{\circ} \mathrm{C}, 42^{\circ} \mathrm{C}\right.$ e $47^{\circ} \mathrm{C}$ ) ocorre uma expressão diferencial de SmPOMP e aumento na atividade $20 \mathrm{~S}$ do proteassoma. Além disso, os níveis proteicos correspondentes às subunidades $20 \mathrm{~S}$ proteassomais aumentam de maneira dependente a elevação da temperatura. Em relação às proteínas poliubiquitinadas o mesmo perfil foi observado, sugerindo, desta forma, um controle a nível transcricional, possivelmente ativando a transcrição de enzimas pertencentes ao sistema de ubiquitinação. Analisando os nossos resultados, podemos observar que o perfil de expressão dos genes SmHul5 e SmUbp6 foram diferentemente regulados após estresse térmico. A expressão de $\mathrm{SmHul5}$ foi positivamente regulada na temperatura de $42^{\circ} \mathrm{C}$ enquanto que um aumento na expressão do gene SmUbp6 foi observado somente na 
temperatura de $40^{\circ} \mathrm{C}$. Estes resultados sugerem que estes dois genes são regulados por mecanismos diferentes em resposta a elevações na temperatura. Deste modo, nossos resultando estão de acordo com os dados descritos por Moreira (2008) e apontam para a síntese de novas populações de proteassoma durante o estresse térmico. Em adição, o aumento na expressão da enzima ubiquitina ligase $\mathrm{SmHul5}$, parece estar relacionado com o aumento na expressão da maquinaria de ubiquitinação da célula conforme sugerido por Fujimuro e colaboradores (1997) e também evidenciam o importante papel desta enzima na resposta ao estresse térmico como foi relatado por Fang e Mayor (2012). O aumento na atividade 20S do proteassoma observado por Moreira (2008) sugere que o acúmulo de proteínas poliubiquitinadas provavelmente está relacionado ao aumento na expressão de enzimas do sistema de ubiquitinação e não com a inibição do proteassoma. Por fim, o aumento na expressão da enzima deubiquitinadora SmUbp6 pode estar relacionado com o acúmulo de proteínas poliubiquitinadas, sendo um evento compensatório na tentativa de diminuir o acúmulo das proteínas ubiquitinadas pelo parasito.

\subsection{Caracterização do estresse oxidativo}

O parasito S. mansoni apresenta diversos estágios de desenvolvimento e necessita se adaptar as condições do ambiente e do hospedeiro (BENDER et al., 2002). Para que possa sobreviver a diferentes condições que são impostas ao longo do seu ciclo de vida, este parasito deve-se adaptar a estas condições, modulando a sua expressão gênica para o controle de diversos processos celulares (EL-ANSARY, 2003). Deste modo, o parasito apresenta um constante desafio de se manter vivo em ambientes desfavoráveis, o que resultou na seleção de diversos processos capazes de reparar os danos resultantes, evitar a formação e eliminar as espécies reativas de oxigênio. Assim, os vermes adultos são capazes de sobreviver por muitos anos no interior do sistema vascular de seres humanos sem que sejam danificados ou eliminados pelo hospedeiro (VIEIRA et al., 2007).

Os vermes adultos de S. mansoni residem no sistema porta-hepático e são expostos a espécies reativas de oxigênio oriundas do seu processo respiratório ou como resultado das respostas imunes do hospedeiro. Sendo assim, para minimizar o estresse oxidativo, estes parasitos possuem um elaborado sistema de detoxificação (ALGER; WILLIAMS, 2002). Já foram descritos e caracterizados diversos sistemas de defesa antioxidante em S. mansoni, sendo os principais representados por duas isoformas de superóxido dismutase $(\mathrm{Cu}-\mathrm{Zn})$ (SOD), Peroxirredoxinas (Prxs), glutationa peroxidase (GPX), citocromo c peroxidase, cinco 
isoformas de glutationa-S-Transferase (GST), glutationa redutase e Tiorredoxina redutase. $\mathrm{Na}$ maioria das células, o peróxido de hidrogênio é removido pela enzima catalase, no entanto, em S. mansoni esta enzima não tem sido detectada (CALLAHAN et al., 1988; MKOJI et al., 1988; NARE et al., 1990; HONG et al., 1992a; WILLIAMS et al., 1992; CAMPOS et al., 1995; SAYED et al., 2006). Além disso, Girardini e colaboradores (2005) demonstraram que a enzima Ferredoxina-NADP(H) oxidoredutase $(\operatorname{SmFNR})$ apresenta níveis elevados de expressão nas fases de cercárias, esquistossômulos, miracídios e esporocistos conferindo ao parasito proteção contra o estresse oxidativo. Moskovitz (2005) descreveu o sistema de defesa antioxidante composto pela enzima metionina sulfóxido redutase (Msr), o qual funciona como um antioxidante que reduz resíduos de metionina oxidada em proteínas. Oke e colaboradores (2009) demonstraram um alto nível de expressão do gene Msr em ovos de S. mansoni, indicando assim, que existe expressão da proteína Msr em resposta ao estresse oxidativo e que estas enzimas podem ser necessárias para a sobrevivência do parasito.

Resultados anteriores demonstraram que esporocistos de $S$. mansoni mantidos em cultura in vitro são altamente sensíveis a estresse oxidativo induzido com peróxido de hidrogênio (HAHN et al., 2001), e que a exposição de esporocistos in vitro para ROS, em especial $\mathrm{H}_{2} \mathrm{O}_{2}$, desencadeia a indução de genes que codificam para várias proteínas antioxidantes (ZELCK; VON JANOWSKY, 2004; VERMEIRE; YOSHINO, 2007). Mkoji e colaboradores (1988) demonstraram que concentrações de peróxido de hidrogênio menores que $0,1 \mathrm{mM}$ não tem efeito tóxico em esquistossômulos e vermes adultos, enquanto que a concentração de $1 \mathrm{mM}$ provocou a morte de $100 \%$ dos esquistossômulos e vermes adultos. Além disso, foi demonstrado que na concentração de $0,25 \mathrm{mM}, 100 \%$ dos esquistossômulos são mortos, ao passo que $100 \%$ dos vermes adultos sobrevivem. Este estudo demonstrou a diferença de sensibilidade entre os estágios de desenvolvimento de S. mansoni ao estresse oxidativo e de acordo com outros trabalhos na literatura (NARE et al., 1990; HONG et al., 1992b).

Nossos resultados demonstram que vermes adultos de $S$. mansoni são extremamente sensíveis a estresse oxidativo induzido com altas concentrações de peróxido de hidrogênio. Neste trabalho, nós testamos uma faixa crescente de concentrações de peróxido de hidrogênio $(100 \mu \mathrm{M}-5 \mathrm{mM})$ a fim de definir a maior concentração de peróxido de hidrogênio que não alterasse a viabilidade de vermes adultos de $S$. mansoni em relação ao tratamento controle. A padronização da concentração de peróxido de hidrogênio a ser utilizada na indução de estresse oxidativo permitiu a escolha de uma concentração que não 
comprometesse as análises bioquímicas devido á perda de funções, decorrentes dos danos celulares causados pelo estresse oxidativo.

Como observado, nas concentrações de $100 \mu \mathrm{M}, 200 \mu \mathrm{M}$ e $300 \mu \mathrm{M}$ não houve alteração da viabilidade dos vermes adultos de $S$. mansoni após 24 h de cultivo in vitro. Estes resultados demonstram a alta tolerância de vermes adultos a baixas concentrações peróxido de hidrogênio. Os danos provocados pelo estresse oxidativo foram mais evidentes nas maiores concentrações de peróxido de hidrogênio, sendo a mortalidade de vermes adultos na concentração de $500 \mu \mathrm{M}$ igual a $75 \%$ nas primeiras $24 \mathrm{~h}$ de cultivo in vitro e de $100 \%$ após 120 h de cultivo. Nas concentrações acima de $1 \mathrm{mM}$ foi possível observar $100 \%$ de mortalidade dos vermes. Nossos resultados estão de acordo com outros trabalhos na literatura que demonstraram a susceptibilidade de vermes adultos de $S$. mansoni ao estresse oxidativo (MKOJI et al., 1988).

O estresse oxidativo alterou diversos processos em vermes adultos de $S$. mansoni. Os resultados do nosso trabalho demonstraram uma redução significativa na produção de ovos nas concentrações acima de $200 \mu \mathrm{M}$ de peróxido de hidrogênio. Nas concentrações a partir de $500 \mu \mathrm{M}$ a diminuição das ovoposição foi relacionada à alta porcentagem de separação dos casais e a mortalidade dos vermes adultos. No entanto, na concentração de $300 \mu \mathrm{M}$ foi observada uma diminuição na ovoposição sem alteração na viabilidade dos vermes e sem a separação dos casais, sugerindo que esta concentração de peróxido de hidrogênio pode estar afetando vias de sinalização e processos relacionados com a ovoposição. A produção de ovos é responsável pela progressão do ciclo de vida e imunopatologia durante esquistossomose, e as moléculas associadas ao parasito estão sendo investigadas como potenciais novos alvos quimioterapêuticos (FITZPATRICK et al., 2007).

O tegumento de esquistossômulos e vermes adultos apresenta uma estrutura intrigante formada por uma única camada citoplasmática multinucleada (sincício) que cobre todo o verme e está ligada à corpos celulares nucleados por conexões citoplasmáticas que atravessam a musculatura (HELLEMOND et al., 2006). A superfície de interação com o hospedeiro consiste de duas bicamadas lipídicas que revestem o sincício. As duas membranas da superfície externa do tegumento são heptalaminares e formam poços superficiais que aumentam substancialmente a área de superfície dos vermes (HOCKLEY, 1973; GOBERT et al., 2003). O tegumento apresenta importância para modulação da resposta do hospedeiro e a sobrevivência do parasito, absorção de nutrientes, absorção seletiva de drogas, metabolismo de lipídeos e colesterol, além de outros processos 
fisiológicos (RUPPEL; MCLAREN, 1986; PEARCE; MACDONALD, 2002; VAN DER KLEIJ; YAZDANBAKHSH, 2003; FAGHIRI; SKELLY, 2009; PEREIRA et al., 2011).

$\mathrm{Na}$ literatura vários compostos exibindo atividade esquistossomicida tem sido descritos. Em sua maioria, estes compostos apresentam como alvo as moléculas presentes no tegumento de Schistosoma. Recentemente, Luz e colaboradores (2012) descreveram a atividade esquistossomicida de nanopartículas de PLGA carregadas com Curcumina, as quais promoveram a morte de $100 \%$ dos parasitos nas concentrações de $50 \mu \mathrm{M}$ e $100 \mu \mathrm{M}$, além de alterações parciais no tegumento nas concentrações acima de $40 \mu \mathrm{M}$. Mostafa e colaboradores (2011) demonstraram que vermes adultos de S. mansoni recuperados de camundongos tratados com extrato de Zingiber officinale apresentam diminuição do número de espinhos nos tubérculos, extensiva erosão e aparecimento de bolhas ao redor dos tubérculos no tegumento.

Keiser e colaboradores (2011) descreveram a extensiva formação de bolhas no tegumento de vermes adultos machos recuperados após perfusão hepática de camundongos tratados com uma combinação de $60 \mathrm{mg} / \mathrm{kg}$ de mefloquine e $170 \mathrm{mg} / \mathrm{kg}$ praziquantel. Miltefosine, primeira droga a ser liberada para o tratamento da leishmaniose, demonstrou-se um composto promissor para síntese de derivados com atividade esquistossomicida (EISSA et al., 2011). Neste trabalho, miltefosine mostrou atividade in vivo contra diferentes estágios de desenvolvimento de $S$. mansoni e $S$. haematobium, induzindo severas alterações no tegumento de vermes adultos. Além disso, de acordo com os resultados obtidos, a membrana externa e a bicamada de lipídeos de $S$. mansoni demonstrou ser extremamente sensível ao tratamento com miltefosine. Bertão e colaboradores (2012) demonstraram que o tratamento de vermes adultos de $S$. mansoni com miltefosine provocou a morte dos parasitos $3 \mathrm{~h}$ após incubação com o composto, sendo a mortalidade máxima após 24 h de tratamento. Neste trabalho, a morte dos parasitos foi precedida por danos provocados no tegumento, caracterizados por descamação, redução de espinhos e erosão, formação e ruptura de bolhas e emergência de buracos no tegumento. Como podemos perceber, o tegumento de $S$. mansoni é importante para o sobrevivência do parasito e a análise dos danos provocados por diferentes tratamentos permite o entendimento dos mecanismos de defesa utilizados por este parasito para adaptar-se as variadas condições de estresse.

Os nossos resultados de microscopia eletrônica de varredura revelaram que vermes adultos de $S$. mansoni são extremamente resistentes a danos oxidativos nas menores concentrações de peróxido de hidrogênio, sendo esta resistência observada na ausência de danos no tegumento de vermes adultos tratados com as concentrações de $100 \mu \mathrm{M}, 200 \mu \mathrm{M}$, 
$300 \mu \mathrm{M}, 400 \mu \mathrm{M}$ e $500 \mu \mathrm{M}$. Nos vermes adultos tratados com $10 \mu \mathrm{M}$ de praziquantel (controle positivo) podemos observar bruscas mudanças na morfologia do tegumento, tais como diminuição do número de tubérculos no tegumento, aparecimento de bolhas entre os tubérculos, diminuição no número de espinhos nos tubérculos, ruptura das bolhas com emergência de buracos e extensiva descamação no tegumento. Estes resultados estão de acordo com outros trabalhos na literatura (SHUHUA et al., 2000; NEVES et al., 2011).

Praziquantel induz modificações nos fosfolipídeos e na fluidez da membrana, e estas mudanças podem produzir alterações na permeabilidade da membrana para íons ou efeitos indiretos em receptores ou canais (HARDER et al., 1988; LIMA et al., 1994; GREENBERG, 2005). O tratamento de vermes adultos de $S$. mansoni com praziquantel afeta a homeostase de cálcio, por um mecanismo molecular ainda desconhecido (REDMAN et al., 1996). A exposição de vermes adultos a praziquantel promove uma rápida e permanente contração muscular (FETTERER et al., 1980), rompimento no tegumento (BECKER et al., 1980), o que consequentemente acarreta a exposição de antígenos do parasito na superfície (HARNETT; KUSEL, 1986).

Os canais iônicos são importantes alvos de drogas que demonstram um papel crucial no controle de diversos processos fisiológicos (HILLE, 2001). De acordo com Kaczorowski e colaboradores (2008), os canais iônicos controlados por voltagem são responsáveis por gerar e controlar o potencial de membrana em células excitáveis, sendo desta forma, essenciais para a homeostase iônica. Ishii e colaboradores (2006) e Wyrsch e colaboradores (2012) demonstraram que o estresse oxidativo com peróxido de hidrogênio promove a mobilização de $\mathrm{Ca}^{2+}$ e regulação de canais de cálcio. Recentemente, tem sido relatados exemplos de drogas efetivas visando canais de sódio, de potássio e cálcio (BERRIMAN et al., 2009). Morais (2012) demonstrou que o tratamento de vermes adultos de S. mansoni com MG132 promoveu o repressão de genes relacionados com diversos canais de íons como: canal de potássio ativado por cálcio (Smp_156150), canal ativado por hiperpolarização de sódio/potássio (Smp_153100), canais de potássio da família Twik (Smp_046640, Smp_155970) e canais de cálcio dependentes de voltagem (Smp_020270, Smp_020170, Smp_004730).

Analisando nossos resultados observamos que a morfologia do tegumento de vermes adultos oriundos de estresse oxidativo com $800 \mu \mathrm{M}$ de $\mathrm{H}_{2} \mathrm{O}_{2}$ apresentou extensa descamação, formação de bolhas entre os tubérculos, diminuição de espinhos e inchaço nos tubérculos. Além disso, em vermes adultos fêmeas observamos extensa descamação e formação de erupções no tegumento, as quais rompem-se ocasionando descamação e 
buracos no tegumento. $\mathrm{O}$ tratamento dos vermes com $1 \mathrm{mM}$ de peróxido de hidrogênio provocou alterações principalmente na região da ventosa ventral. Como podemos perceber, neste trabalho, foi possível identificar que as mudanças provocadas no tegumento de vermes adultos de $S$. mansoni após estresse oxidativo são semelhantes às alterações provocadas pelo tratamento com $10 \mu \mathrm{M}$ de praziquantel, sugerindo, desta forma, um mecanismo de ação semelhante entre os dois tipos de estresse (oxidativo e químico). Este mecanismo parece ser influenciado pelos níveis de cálcio intracelular, os quais estão sob o controle de canais de cálcio na membrana dos vermes adultos de S. mansoni, cujo funcionamento e regulação podem estar alterados na condição de estresse oxidativo.

\subsection{Determinação da produção de espécies reativas de oxigênio (ROS) no estresse químico com Curcumina, IBMX e MG132}

O aumento na expressão de genes relacionados aos sistemas de defesa antioxidante bem como de protéinas de choque térmico sugerem que o estresse químico provocado com Curcumina, IBMX e MG132 podem estar relacionados com o aumento de ROS intracelular e estresse no sistema de controle de qualidade de proteínas celulares.

Lin e colaboradores (2008) sugerem que Curcumina diretamente aumenta o estresse oxidativo intracelular e gera espécies reativas de oxigênio (ROS), além disso, existem várias evidências apontando para a produção ROS induzida por Curcumina em linhagens de células cancerígenas, levando a apoptose destas células (LEE et al. 2010; WATSON et al. 2010). Cheng e colaboradores (2010) demonstraram que Curcumina induz resposta a proteínas desdobradas (UPR) por induzir estresse no retículo endoplasmático, regulando a expressão de protéinas envolvidas na homeostase do retículo endoplasmático. Tem sido descrito que diferentes tipos de estresses comprometem o retículo endoplasmático interferindo no processo de maturação o que resulta na acumulação de proteínas maldobradas e na ativação do mecanismo de resposta a estresse conhecido como UPR (unfolded protein response) (DIEHL et al, 2011). A UPR é caracterizada pelo aumento na transcrição de genes que codificam para chaperonas moleculares do retículo endoplasmático incluindo BIP/GRP78, GRP94, proteína dissulfeto isomerase (PDI), do fator de transcrição próapoptótico CHOP e do gene de dano ao DNA-153 (GADD153) (ZINSZNER et al., 1998). Em muitas condições patofisiológicas, a ativação da UPR representa um efeito citoprotetor caracterizado por uma redução global na síntese de proteínas com aumento seletivo na síntese de proteínas com função de proteção da célula (CHAKRABARTI et al., 2011; 
KORENNYKH; WALTER, 2012). A geração de ROS intracelular aumenta o estresse sobre o retículo endoplasmático e evidências sugerem que a produção de ROS e o estresse oxidativo não só coincidem em uma situação de estresse do retículo endoplasmático, mas são componentes integrais da UPR (SANTOS et al., 2009).

Nossos resultados sugerem o aumento na produção de ROS em vermes adultos de $S$. mansoni após tratamento com Curcumina. Nayak e colaboradores (2012) mostraram que curcumina induz apoptose e estresse oxidativo no nematódeo Setaria cervi, sendo relatado o aumento na atividade das enzimas antioxidantes SOD e GST, aumento este possivelmente relacionado com a alta produção de ROS induzida por Curcumina. Aqui nós relatamos um aumento na expressão dos genes SmGPxl, SmGPx2, SmSOD e SmTGR após 24 horas de tratamento com $5 \mu \mathrm{M}$ de Curcumina. Em C. elegans, tem sido relatado a upregulação de genes do sistema antioxidante durante estresse oxidativo (RAAMSDONK; HEKIMI, 2010). Além disso, Curcumina também estimula o aumento no nível de SOD em células cancerígenas e células de fígado de mamíferos (RAJESWARI 2006; KUHAR et al. 2007).

Magalhaes (2009) demonstrou que o tratamento de vermes adultos de S. mansoni com $5 \mu \mathrm{M}$ de Curcumina induz uma redução na viabilidade sem provocar a morte dos parasitos. No entanto, em concentrações maiores $(20,50$ e $100 \mu \mathrm{M})$ ocorre $100 \%$ de mortalidade dos parasitos após tratamento com Curcumina. Sendo assim, o aumento na expressão dos genes do sistema antioxidante de S. mansoni observado neste trabalho após tratamento com curcumina pode ser devido ao aumento de ROS intracelular e pode explicar os resultados observados por Magalhaes (2009), sendo estas enzimas importantes para a sobrevivência dos parasitos. Além disso, nossos resultados não permitem dizer se o perfil de expressão destes genes continua aumentado nas concentrações maiores de Curcumina, uma vez que não analisamos o perfil de expressão destes genes nestas concentrações.

$\mathrm{O}$ estresse químico induzido com Curcumina provocou um aumento na expressão dos genes das proteínas de choque térmico ( $S m H s p 70$ e $S m H s p 40$ ). Khan e Heikkila (2011) demonstraram, em Xenopus laevis, que Curcumina inibe a atividade proteassoma e induz a acumulação de proteínas de choque térmico (HSPs). As proteínas de choque térmico representam um grande grupo de chaperonas moleculares envolvidas em muitos processos celulares incluindo síntese proteica, dobramento/montagem, translocação para membrana e degradação (KATSCHINSKI, 2004; MORIMOTO, 2008). Além disso, as HSPs são responsáveis pelo correto dobramento e função de muitas proteínas, e são também importantes componentes da resposta ao estresse do retículo endoplasmático (MARCU et al., 2002; OYADOMARI et al., 2006). Meares e colaboradores (2008) demonstraram que 
HSP105 é importante para sinalização de apoptose após ativação de UPR provocada por estresse no retículo endoplasmático por interagir com os mediadores de UPR GRP78 e GSK3. Deste modo, sugerimos que o aumento na expressão dos genes para HSPs mostrado em nossos resultados parece estar relacionado com resposta a UPR devido ao estresse no retículo endoplasmático induzido por Curcumina.

Wu e colaboradores (2002) e Emanuele e colaboradores (2002) relatam a indução de apoptose após o aumento na formação de ROS intracelular em células HEK 293 e células de hepatoblastoma HepG2. Além disso, tem sido descrito que inibidores do proteassoma causam disfunção mitocondrial com subsequente liberação de citocromo $\mathrm{C}$, a qual leva a perda da viabilidade celular, sendo estes efeitos devido a formação de ROS e diminuição dos níveis de GSH (glutationa) intracelular (QIU et al., 2000; LING et al., 2003). Han e colaboradores (2009) demonstraram que a formação de ROS e diminuição de GSH levam a inibição do crescimento celular em células HeLa. MG132 promove o aumento de ROS intracelular (HAN et al., 2010; FAN et al., 2011; YOU; PARK, 2011), e Bush e colaboradores (1997) demonstraram que inibidores do proteassoma promovem um acúmulo de proteínas mal-dobradas, o qual estimula a expressão de proteínas heat-shock citosólicas (Hsp70) e chaperonas moleculares do retículo endoplasmático (BiP, ERp72 e Grp94), dessa forma induzindo UPR e HSR.

Após o tratamento de vermes adultos de S. mansoni com $50 \mu \mathrm{M}$ de MG132 observamos um aumento de 2 vezes na produção de ROS intracelular, porém, nenhuma alteração na expressão dos genes relacionados ao sistema de defesa antioxidante e proteínas de choque térmico foi observada. Guerra-Sá (2000) demonstrou que vermes adultos tratados com $50 \mu \mathrm{M}$ de MG132 apresentam uma redução na viabilidade, diminuição da ovoposição com a separação dos casais, sem haver, entretanto a morte dos vermes. Morais (2012) relatou a repressão de vários genes envolvidos com apoptose após o tratamento de vermes adultos com a mesma concentração de MG132. Neste trabalho, Morais, sugere que a via mitocondrial regulada pela proteína Bcl-2 em S. mansoni está inibida devido a repressão da transcrição de alguns dos seus componentes chaves, e também pela alta expressão de IAP1 (homólogo ao inibidor de apoptose 1), que por sua vez inibe a via das caspases. Deste modo, com a inibição da via apoptótica o parasito perde um mecanismo essencial de controle da homeostase celular o que pode gerar danos a ele e explicar a diminuição da viabilidade dos parasitos. Sendo assim, sugerimos aqui que o aumento na produção de ROS intracelular por vermes adultos após tratamento com MG132 pode estar relacionado da mesma forma com a redução na viabilidade dos parasitos. 
O inibidor de fosfodiesterase IBMX provocou um aumento de ROS intracelular nas duas concentrações que foram testadas. Além disso, houve a indução na expressão dos genes SmGPx1 e SmGPx2 após tratamento dos parasitos com $200 \mu \mathrm{M}$ de IBMX, sendo este aumento não observado na menor concentração testada $(80 \mu \mathrm{M})$. Em relação a expressão dos genes $S m H s p 70$ e $S m H s p 40$, observamos um aumento na expressão após tratamento com $80 \mu \mathrm{M}$ de IBMX. Moreira (2008) caracterizou os efeitos in vitro de IBMX em vermes adultos de S. mansoni, sendo relatada uma drástica redução no número de ovos, sem, no entanto ocorrer a separação dos casais de vermes e alteração na viabilidade dos parasitos. Existe pouca informação na literatura sobre o efeito de inibidores de fosfodiesterase em relação a produção de ROS intracelular e estresse oxidativo (SAVAS et al., 2010). Alguns autores relatam um aumento na produção de ROS intracelular com subsequente aumento na expressão de enzimas antioxidantes e diminuição do estresse oxidativo decorrente da upregulação da enzima antioxidante (GPx) (SPERANZA et al., 2008; HATZIMOURATIDIS et al., 2009). Sendo assim, diante dos nossos resultados sugerimos que vermes adultos de $S$. mansoni tratados com o IBMX apresentam um aumento no nível de ROS, sendo o estresse oxidativo atenuado pelo aumento na expressão das enzimas SmGPx1 e SmGPx2, e podendo este efeito explicar a não diminuição da viabilidade dos parasitos observada por Moreira (2008).

\subsection{Perfil de expressão de protéinas de vermes adultos de $S$. mansoni em resposta a estresse oxidativo e térmico}

O proteoma em Schistosoma tornou-se uma ferramenta de grande importância tanto para estudo da interação parasito-hospedeiro quanto para a busca de alvos para terapêutica da esquistossomose. Os avanços nos estudos com proteoma permitiram a identificação de proteínas expressas diferencialmente nos diversos estágios de desenvolvimento do parasito, proteínas gênero-específicas, proteínas diferencialmente expressas em frações de membrana e do tegumento, proteínas das secreções dos ovos e fases larvais, proteínas expostas na superfície de vermes adultos e proteínas do hospedeiro presentes no tecido do parasito (CURWEN et al., 2004; CHENG et al., 2005; LIU et al., 2006; GUILLOU et al., 2007; DEMARCO; VERJOVSKI-ALMEIDA, 2009). A identificação destas proteínas permitiu um melhor entendimento dos mecanismos utilizados pelo parasito para evasão do sistema imune do hospedeiro, resposta ao estresse celular bem como a invasão e permanência do parasito em seu hospedeiro. Por exemplo, proteínas relacionadas à resposta a estresse, proteólise, 
detoxificação e modulação imune foram identificadas durante transformação in vitro de miracídios para esporocistos, evidenciando um possível papel protetivo crucial durante este período de transição (WU et al., 2009). Liu e colaboradores (2009) identificaram que as proteínas HSP70, HSP90 e HSP97 constituem uma grande família de proteínas secretadas/excretadas por vermes adultos de S. japonicum, demonstrando assim que estas proteínas podem ter um papel importante na imunomodulação na relação parasitohospedeiro.

Neste trabalho, observamos que indução de estresse oxidativo e estresse térmico em vermes adultos de S. mansoni alterou o perfil de expressão de proteínas do parasito. As proteínas diferencialmente expressas apresentaram um aumento na sua expressão que foi significativamente diferente dos vermes adultos não tratados. Relatamos a expressão diferencial de 23 proteínas após estresse oxidativo com $200 \mu \mathrm{M}$ peróxido de hidrogênio por 24 h e 24 proteínas após estresse térmico $\left(42^{\circ} \mathrm{C} 1 \mathrm{~h}\right)$. As protéinas diferencialmente expressas foram relacionadas as cinco processos básicos: 1) processos metabólicos, 2) proteínas associadas aos microtúbulos, 3) resposta ao estresse, 4) proteínas de ligação e 5) proteínas regulatórias. As células apresentam mecanismos de respostas adequados para uma grande diversidade de estímulos (KASTLE; GRUNE, 2012). Deste modo, após determinado estímulo ocorre à indução de genes pertencentes a sete diferentes classes, sendo elas: 1 . Genes da família das proteínas de resposta a choque térmico (Hsps), 2. Genes relacionados ao sistema proteolítico, 3. Enzimas de reparo de ácidos nucléicos, 4. Enzimas metabólicas, 5. Proteínas regulatórias, 6. Proteínas relacionadas à estabilização do citoesqueleto 7. Proteínas envolvidas com transporte, detoxificação e estabilidade da membrana (JANTSCHITSCH; TRAUTINGER, 2003; MALMENDAL et al., 2006; RICHTER et al., 2010; TOIVOLA et al., 2010; WELKER et al., 2010).

Conforme relatado acima, as proteínas que tiveram sua expressão aumentada após estresse oxidativo e térmico pertencem às classes de proteínas que apresentam indução após estresse celular. Além disso, observamos que 18 proteínas foram igualmente upreguladas tanto no estresse oxidativo como no estresse térmico. Após categorização das proteínas com expressão induzida, observamos que a maioria das proteínas (32\% e 38\%) estão envolvidas em processos celulares, $41 \%$ e $46 \%$ das proteínas estão envolvidas em funções de ligação e $41 \%$ e $39 \%$ das proteínas são componentes intracelulares. Deste modo, as proteínas que tiveram sua expressão induzida após estresse oxidativo e térmico foram: Calreticulina, Tropomiosina, Cadeia beta da Tubulina, Alfa tubulina, Aldeído desidrogenase, Enolase, proteína de ligação ao cálcio, cadeia leve regulatória da miosina, Ciclofilina, antígeno 28K, 
Fosfoglicerato mutase, Gliceraldeído-3-fosfato desidrogenase, Limpetin, Malato desidrogenase, cadeia leve da miosina, Creatina kinase, subunidade alfa da ATP sintase mitocondrial, cadeia leve da dineína. Quanto as proteínas com expressão aumentada somente no estresse oxidativo, observamos: Triose fosfato isomerase, subunidade alfa 3 do proteassoma, 14-3-3 epsilon 2, Glutationa S-transferase $26 \mathrm{kDa}$ e Tiorredoxina, e quanto as proteínas com aumento de expressão no estresse térmico tivemos: Fosfoglicerato kinase, $\mathrm{Cu} / \mathrm{Zn}$ - Superóxido dismutase, Antígeno do tegumento (Sm20.8), Ubiquitina e duas isoformas da proteína de choque térmico Hsp70.

Aqui escolhemos discutir o aumento de algumas proteínas que estão diretamente relacionadas com resposta ao estresse celular e também proteínas relacionadas a vias importantes para a sobrevivência do parasito. Calreticulina é uma proteína com alta afinidade de ligação à íons cálcio localizada no lúmen do retículo endoplasmático (ER) e em vias secretórias no citoplasma, núcleo e membrana celular (KRAUSE; MICHALAK, 1997). Esta proteína é uma chaperona molecular envolvida no sistema de controle de qualidade de protéinas, cuja função é promover a montagem e dobramento de proteínas e glicoproteínas recém-sintetizadas, antes da sua exportação do ER (MICHALAK et al., 1999; LEDERKREMER, 2009). Além disso, esta chaperona desempenha papel importante na sinalização de $\mathrm{Ca}^{2+}$ no retículo endoplasmático, afetando vias e processos dependentes de cálcio, além de prevenir o estresse oxidativo em células do epitélio renal (LIU et al., 1997; COE; MICHALAK, 2009).

Estudos em Schistosoma tem mostrado que esta proteína é expressa em ovos, esporocistos, esquistossômulos e vermes adultos, atingindo níveis relativamente altos na glândula de penetração em cercárias, o que sugere um papel importante na invasão do hospedeiro (SCOTT; MCMANUS, 1999). Park e colaboradores (2001) demonstraram, em Caenorhabditis elegans, um aumento de três vezes na expressão gênica de calreticulina (CRT-1) após estresse térmico e com etanol. Jia e colaboradores (2008) mostraram que a overexpressão de calreticulina previne acumulação de espécies reativas de oxigênio durante hipóxia prolongada por induzir a translocação nuclear do fator de transcrição Nrf2 e promover um aumento na expressão de tiorredoxina em células do epitélio alveolar. Após estresse oxidativo, uma variedade de proteínas celulares podem ser oxidadas e inativadas, desta forma, o aumento de 2,02 vezes na expressão de proteína calreticulina (Smp_030370.1) observado neste trabalho, pode estar relacionado a atividade de chaperona desta proteína, como tentativa de reestruturar proteínas alteradas e também com a regulação e manutenção dos níveis celulares de cálcio. 
As ciclofilinas constituem uma grande e conservada família de proteínas com atividade peptidil-prolil-cis-trans isomerase envolvidas em processos como dobramento de proteínas, tráfego, montagem, apoptose, tolerância a estresse e inflamação (WANG; HEITMAN, 2005). Andreeva e colaboradores (1997) relataram a indução na expressão de ciclofilinas após aumento de temperatura, sendo também demonstrado que as ciclofilinas são proteínas induzidas por calor e outras condições de estresse. Além disso, foi sugerida uma possível associação entre as ciclofilinas e as chaperonas moleculares. O possível papel da ciclofilinas na resposta ao estresse pode estar relacionado com sua propriedade de chaperona molecular sob condições normais e a sua interação com proteínas de choque térmico (HSPs) (ANDREEVA et al., 1999).

Doyle e colaboradores (1999) evidenciaram o efeito protetor de ciclofilina A contra o estresse oxidativo em cardiomiócitos em cultura. Esta proteína pode ligar-se a calreticulina e a glutationa-S-Transferase e esta interação pode favorecer a regulação neuronal de cálcio intracelular e aliviar o estresse oxidativo (REDDY; ATREYA, 1999; PIOTUKH et al., 2005). Boulos e colaboradores (2007) demonstraram que a overexpressão de ciclofilina A em células do córtex neural de ratos pode ter efeito protetor contra estresse oxidativo. Marín-Menéndez e colaboradores (2012) caracterizaram a atividade peptidil-prolil cis-trans isomerase e a atividade de chaperona de oito membros da família de ciclofilinas de Plasmodium falciparum, demonstrando que todas as proteínas apresentam função de chaperonas, demonstrando assim sua função no dobramento correto de proteínas. Vários trabalhos na literatura tem reportado a identificação de genes de ciclofilina em Schistosoma (GOURLAY et al., 2007) e recentemente Han e colaboradores (2012) demonstraram que o gene para ciclofilina A de S. japonicum pode ser um regulador do crescimento e desenvolvimento de esquistossômulos além de ser importante na interação parasitohospedeiro. Desta maneira, o aumento de expressão da proteína ciclofilina em 2,07 e 1,23 vezes no estresse oxidativo e térmico, respectivamente, mostrado por nossos resultados estão de acordo com os dados descritos na literatura.

As proteínas 14-3-3 tem um papel crucial em eventos de sinalização celular, agindo como adaptadores que estimulam a interação proteína-proteína, regulando a sublocalização celular de proteínas e ativando e inibindo enzimas (VAN HEMERT et al., 2001). Além disso, estão envolvidas no controle do ciclo celular, alterações transcricionais em respostas a eventos ambientais de morte celular programada (SILES-LUCAS; GOTTSTEIN, 2003). Em muitos organismos, as diferentes isoformas das proteínas 14-3-3 têm sido caracterizadas de acordo com sua função de chaperona (JEANCLOS et al., 2001). Em outros organismos, as 
proteínas 14-3-3 são também importantes em diversos processos, por exemplo, Lingdan e colaboradores (2012) demonstraram, recentemente, o papel destas proteínas para o ciclo de vida de G. lamblia. Em Schistosoma as proteínas tem um papel na regulação de proteínas PKC durante o desenvolvimento do parasito. A isoforma 14-3-3-1ع1 tem sido caracterizada, em S. mansoni, pela sua capacidade de interagir o domínio fosforilado do receptor de kinase1 (SmRK1), um homólogo do receptor 1 do fator de crescimento $\beta$ (T $\beta \mathrm{RI}$ ), demonstrando assim a importância das proteínas na via de sinalização intracelular mediada por TGF $\beta$ (MCGONIGLE et al., 2001). Thandavarayan e colaboradores (2011) demonstram que a proteína 14-3-3 atua como um cardioprotetor endógeno limitando o desenvolvimento de cardiopatia diabética por limitar o estresse oxidativo, inflamação miocardial, fibrose e hipertrofia, via inibição da via de sinalização envolvendo MAPK p38, MAPKAPK-2 (MAPK ativada por proteína kinase 2) e NF-אB após indução de diabete experimental. Neste trabalho, nossos dados de proteoma permitiram a identificação de três isoformas para as protéinas 14-3-3 (Smp_009760.1, Smp_034840.3 e Smp_002410.1), no entanto, somente a isoforma 14-3-3 epsilon 2 (Smp_002410.1) foi upregulada após estresse oxidativo, demonstrando um papel das isoformas que pode variar de acordo com o tipo de estímulo e função de cada isoforma.

Outra proteína upregulada após indução de estresse oxidativo e térmico foi a proteína regulatória Limpetin, caracterizada por apresentar o domínio LIM contendo motivos ricos nos aminoácidos cisteína e histidina. Estas proteínas têm sido descritas como estando envolvidas na regulação gênica, diferenciação, adesão e motilidade celular, organização do citoesqueleto e transdução de sinais (KADRMAS; BECKERLE, 2004) e também por sua capacidade de interagir com outras proteínas, sendo elementos regulatórios chaves envolvidos em diversas vias de sinalização (FURTADO et al., 2008). Muitos trabalhos na literatura têm descrito que proteínas com domínio LIM podem interagir direta ou indiretamente como o citoesqueleto da célula. Maul e colaboradores (2003) descreveram o papel da proteína EPLIN a qual pode regular diretamente as reações de polimerização e despolimerização de actina. Huot e colaboradores (1997) demonstraram que estresse oxidativo com $\mathrm{H}_{2} \mathrm{O}_{2}$ induz severa fragmentação de F-actina em fibroblastos, além disso, houve nestas células ativação da MAPK p38, a qual mostrou ter um papel central na modulação das respostas do microfilamentos para o estresse oxidativo. Deste modo, levando em consideração a evidência de associação entre proteínas com domínio LIM e os filamentos de actina, bem como a sua reorganização durante o estresse oxidativo, sugerimos aqui que a upregulação de Limpetin observada neste trabalho, pode estar relacionada com os 
danos provocados no tegumento de vermes adultos após indução de estresse oxidativo, o qual pode ter alterado a estrutura e organização dos filamentos de actina no citoesqueleto.

S. mansoni apresenta uma adequada defesa antioxidante composta por sistemas enzimáticos bem caracterizados. Como podemos observar, neste trabalho, após a indução de estresse oxidativo ocorreu um aumento na expressão das proteínas glutationa S-transferase, tiorredoxina e antígeno 28K. Estas proteínas compõem o sistema de defesa antioxidante deste parasito e apresentaram um aumento de expressão igual a 1,35, 1,60 e 1,02, respectivamente. Estas enzimas estão relacionadas ao metabolismo de espécies reativas de oxigênio (ROS) e a detoxificação de produtos oxidados, sendo deste modo, importantes para manutenção do equilíbrio redox (MOURÃO et al., 2009). Outros trabalhos na literatura corroboram com nossos resultados demonstrando que a exposição de S. mansoni à ROS promove a upregulação de diversas proteínas antioxidantes (ZELCK; VON JANOWSKY, 2004; VERMEIRE; YOSHINO, 2007). Além disso, podemos observar que a enzima tiorredoxina foi a proteína que apresentou o maior fold change em sua expressão, sugerindo deste modo que esta proteína representa o principal mecanismo de defesa antioxidante em vermes adultos de S. mansoni. Esta enzima multifuncional vem sendo caracterizada como sendo a principal enzima redox em $S$. mansoni e também como um importante alvo para o desenvolvimento de drogas para este parasito (ALGER; WILLIAMS, 2002; KUNTZ et al., 2007).

A degradação de proteínas oxidadas é realizada de forma seletiva pelo sistema ubiquitina-proteassoma, no entanto, ainda não é totalmente claro se este processo é dependente ou não de ubiquitinação (GRUNE et al., 1997; DAVIES, 2001; SHRINGARPURE et al., 2003; SHANG; TAYLOR, 2011). Fernandes e colaboradores (2006) demonstraram que o estresse oxidativo em células endoteliais da retina upregula a via ubiquitina-proteassoma e aumenta o turnover de conjugados de ubiquitina. Nossos resultados mostram uma upregulação da proteína alfa-3 que forma uma das subunidades do núcleo catalítico do proteassoma $20 \mathrm{~S}$ (subunidade alfa 3). Esta proteína apresentou um incremento de 1,82 vezes em sua expressão após estresse oxidativo com $200 \mu \mathrm{M}$ de peróxido de hidrogênio por 24 horas. Além disso, nossa análise de Western blotting mostrou um aumento do conteúdo proteico de proteassoma 20S após 30 minutos, 1 hora, 4 horas e 24 horas de indução de estresse oxidativo. Deste modo, juntamente, estes resultados sugerem a participação do proteassoma $20 \mathrm{~S}$ na degradação de proteínas oxidadas de vermes adultos de S. mansoni após condição de estresse oxidativo. 
As enzimas metabólicas aldeído desidrogenase, enolase, triose fosfato isomerase, fosfoglicerato mutase, gliceraldeído-3-fosfato desidrogenase, malato desidrogenase e creatina kinase tiveram sua expressão induzida após o estresse oxidativo juntamente com outro grande grupo de proteínas de associação aos microtúbulos (tropomiosina, cadeia beta da tubulina, alfa tubulina, cadeia leve regulatória da miosina, cadeia leve da miosina e cadeia leve da dineína), tiveram sua expressão induzida tanto no estresse oxidativo como no estresse térmico. Tem sido previamente observado que alguns organismos utilizam mecanismos moleculares semelhantes para responder ao choque térmico e ao estresse oxidativo. Young e colaboradores (2004) demonstraram, em E. coli, que estes dois tipos de estresse induzem a expressão de uma variedade de proteínas de choque térmico, como DnaK (homóloga a Hsp70) e DnaJ (homóloga a Hsp40). As propriedades de proteção das proteínas de choque térmico (Hsps), no contexto da resposta ao estresse celular estão relacionadas com o aumento em sua função de chaperona molecular, auxiliando com dobramento correto, transporte e degradação de proteínas modificadas devido ao estresse (CRAIG et al., 1993; PARSELL; LINDQUIST, 1993; AKERFELT et al., 2007; MORIMOTO, 2008). Por exemplo, a via de folding de receptores envolve nove diferentes proteínas Hsps, três peptidil-prolil cis-trans isomerases e ciclofilina. Deste modo, podemos observar que a indução de estrese oxidativo e estresse térmico em vermes de $S$. mansoni provocou a modulação da expressão proteica no intuito de reestabelecer a homeostase celular e permitir a adaptação e sobrevivência do parasito diante de diferentes estímulos estressores. 
6. Conclusões 


\section{Conclusões}

Neste trabalho, foi realizada a caracterização dos genes SmHul5 e SmUbp6 nas fases do ciclo de vida de S. mansoni assim como no estresse oxidativo, térmico e químico, visando compreender os mecanismos de resposta de vermes adultos de S. mansoni aos diferentes estresses e entender a participação do sistema ubiquitina-proteassoma na resposta ao estresse. Diante de nossos resultados, pode-se concluir que: 1. Os genes SmHul5 e SmUbp6 são expressos nas diferentes fases de desenvolvimento do parasito S. mansoni, sendo o nível de expressão significativamente elevado nas fases de esporocistos, esquistossômulos e miracídios, e ausente na fase de cercária. 2. O estresse oxidativo altera o pareamento, motilidade, mortalidade, viabilidade e morfologia do tegumento de vermes adultos de S. mansoni. 3. O perfil de expressão proteica após indução de estresse oxidativo e térmico foi alterado e dezoito proteínas tiveram sua expressão aumentada após estes estresses. 4. A análise de Western blotting para detecção de subunidades $\alpha$ do proteassoma sugere que a degradação de proteínas modificadas durante estresse oxidativo é realizada via proteassoma $20 \mathrm{~S}$ em vermes adultos de S. mansoni. 5. O estresse químico induzido com Curcumina, MG132 e IBMX aumenta a produção de ROS e provoca um aumento da expressão de genes relacionados ao sistema de defesa antioxidante e proteínas de choque térmico em vermes adultos. 6. A análise de PCR em tempo real revelou que a expressão dos genes para as proteínas acessórias do proteassoma SmHul5 e SmUbp6 bem como para a proteína de maturação do proteassoma $(S m P O M P)$ são diferentemente reguladas no estresse químico, oxidativo e térmico. Finalmente, o presente trabalho sugere que o parasito $S$. mansoni utiliza mecanismos de resposta semelhantes para os diferentes tipos de estresse, os quais envolvem a modulação da expressão gênica e proteica como medida adaptativa aos estímulos estressores. 
7.Perspectivas Futuras 


\section{Perspectivas futuras}

Nossos resultados mostram que os genes SmHul5 e SmUbp6 apresentam um alto nível de expressão nas fases de esporocistos, esquistossômulos e miracídios, sugerindo que estes genes são importantes para o desenvolvimento do parasito durante a transição entres as fases larvais. Deste modo, para desvendar a quais processos estes genes estão envolvidos nas fases do ciclo de vida de $S$. mansoni, seria interessante identificar os substratos proteicos ligantes para estas enzimas em cada estágio específico. Deste modo, faz-se necessário a produção de anticorpos específicos para as duas proteínas, os quais poderão ser utilizados tanto na avaliação da expressão proteica através do ciclo de vida de $S$. mansoni, mostrando o comportamento destas proteínas durante o desenvolvimento do parasito, como também em experimentos de coimunoprecipitação e posterior identificação dos ligantes por espectrometria de massas. Além disso, para melhor compreender e caracterizar o envolvimento da via ubiquitina-proteassoma na resposta ao estresse químico com Curcumina, é necessário realizar um ensaio de atividade do proteassoma frente ao tratamento com este composto, bem como a determinação do conteúdo de proteassoma $20 \mathrm{~S}$ e proteínas poliubiquitinadas ainda não mostrados para este parasito em resposta ao estresse induzido com Curcumina. 
8. Referências Bibliográficas 
ADAMS, J.; PALOMBELLA, V.J.; SAUSVILLE, E.A. et al. Proteasome inhibitors: a novel class of potent and effective antitumor agents. Cancer Research, v. 59, p. 2615-2622, 1999.

AKERFELT, M.; TROUILLET, D.; MEZGER, V.; SISTONEN, L. Heat shock factors at a crossroad between stress and development. Annals of the New York Academy of Sciences, v. 1113, p. 15-27, 2007.

ALGER, H. M.; WILLIAMS, D. L. The disulfide redox system of Schistosoma mansoni and the importance of a multifunctional enzyme, thioredoxin glutathione reductase. Molecular \& Biochemical Parasitology, v. 121, p. 129-139, 2002.

ALGER, H. M.; SAYED, A. A.; STADECKER, M. J.; WILLIAMS, D. L. Molecular and enzymatic characterization of Schistosoma mansoni thioredoxin. International Journal for Parasitology, v. 32, p. 1285-1292, 2002.

ALLAM, G. Immunomodulatory effects of curcumin treatment on murine schistosomiasis mansoni. Immunobiology, v. 214, p. 712-727, 2009.

AL REFAII, A.; ALIX, J. H. Ribosome biogenesis is temperature-dependent and delayed in Escherichia coli lacking the chaperones DnaK or DnaJ. Molecular Microbiology, v. 71, p. 748-762, 2009.

AMARAL, R. S.; PORTO, M. A. S. Evolução e situação atual do controle da esquistossomose no Brasil. Revista da Sociedade Brasileira de Medicina Tropical, Uberaba, v. 27, p. 73-90, 1994.

AMERIK, A. Y.; HOCHSTRASSER, M. Mechanism and function of deubiquitinating enzymes. Biochimica et Biophysica Acta, v. 1695, p. 189- 207, 2004.

ANDREEVA, L.; MOTTERLINI, R.; GREEN, C. J. Cyclophilins Are Induced by Hypoxia and Heat Stress in Myogenic Cells. Biochemical and Biophysical Research Communications, v. 237, p. 6-9, 1997.

ANREEVA, L.; HEADS, R.; GREEN, C. J. Cycophilins and ther possible role in the stress response. International Journal of Experimental Pathology, v. 80, p. 305-315, 1999.

Applied Biosystems. User Bulletin \#2. ABI PRISM 7700 Sequence Detection Systems: Relative Quantitation of Gene Expression. December, 1997.

ARAGON, A. D.; IMANI, R. A.; BLACKBURN, V. R.; CUNNINGHAM, C. Microarray based analysis of temperature and oxidative stress induced messenger RNA in Schistosoma mansoni. Molecular \& Biochemical Parasitology, v. 162, p. 134-141, 2008.

ARAUJO, C. A.; ALEGRIO, L. V.; GOMES, D. C. et al. Studies on the effectiveness of diarylheptanoids derivatives against Leishmania amazonensis. Memórias do Instituto Oswaldo Cruz, v. 94, p. 791-794, 1999.

AVIRAM, S.; KORNITZER, D. The ubiquitin ligase Hul5 promotes proteassomal processivity. Molecular and Cellular Biology, v. 30, p. 985-994, 2010. 
BADER, N.; GRUNE, T. Protein oxidation and proteolysis. Biological Chemistry, v. 387, p. 1351-1355, 2006.

BECKER, B.; MEHLHORN, H.; ANDREWS, P.; THOMAS, H.; ECKERT, J. Light and electron microscopic studies on the effect of praziquantel on Schistosoma mansoni, Dicrocoelium dendriticum, and Fasciola hepatica (Trematoda) in vitro. Zeitschrift für Parasitenkunde, v. 63, p. 113-128, 1980.

BEDFORD, L.; PAINE, S.; SHEPPARD, P. W.; MAYER, R.J.; ROELOFS, J. Assembly, Structure and Function of the $26 \mathrm{~S}$ proteasome. Trends Cell Biology, v. 20, p. 391-401, 2010.

BENDER, R. C.; BIXLER, L. M.; LERNER, J. P.; BAYNE, C. J. Schistosoma mansoni sporocysts in culture: host plasma hemoglobin contributes to in vitro oxidative stress. Journal of Parasitology, v. 88, p. 14-18, 2002.

BERRIMAN, M.; HAAS, B. J.; LOVERDE, P. T.; WILSON, R. A. et al. The genome of the blood fluke Schistosoma mansoni. Nature, v. 460, p. 352-358, 2009.

BERTÃO, H. G.; DA SILVA, R. A.; PADILHA, R. J. et al. Ultrastructural Analysis of miltefosine-induced surface membrane damage in adult Schistosoma mansoni BH strains worms. Parasitology Research, v. 110, p. 2465-2473, 2012.

BORODOVSKY, A.; OVAA, H.; KOLLI, N. et al. Chemistry-Based functional proteomics reveals novel members of the deubiquitinating enzyme family. Chemistry \& Biology, v. 9, p. 1149-1159, 2002.

BOTELHO-MACHADO, C.; CABRAL, F. J.; SOARES, C. S. et al. Characterization and mRNA expression analysis of PI31, an endogenous proteasome inhibitor from Schistosoma mansoni. Parasitology Research, v. 107, p. 1163-1171, 2010.

BOULON, S.; WESTMAN, B. J.; HUTTEN, S.; BOISVERT, F. M.; LAMOND, A. I. The nucleolus under stress. Molecular Cell, v. 40, p. 216-227, 2010.

BOULOS, S.; MELONI, B. P.; ARTHUR, P. G. et al. Evidence that intracellular cyclophilin $\mathrm{A}$ and cyclophilin A/CD147 receptor-mediated ERK1/2 signalling can protect neurons against in vitro oxidative and ischemic injury. Neurobiology of Disease, v. 25, p. 54-64, 2007.

BROOKS, C. L.; GU, W. p53 Ubiquitination: Mdm2 and Beyond. Molecular Cell, v. 21, p. 307-315, Feb., 2006.

BURROWS, J. F.; JOHNSTON, J. A. Regulation of cellular responses by deubiquitinating enzymes: an update. Frontiers in Bioscience, v. 17, p. 1184-1200, 2012.

BUSH, K. T.; GOLDBERG, A. L., NIGAM, S. K. Proteasome Inhibition Leads to a Heatshock Response, Induction of Endoplasmic Reticulum Chaperones, and Thermotolerance. The Journal of Biological Chemistry, v. 272, p. 9086-9092, 1997. 
CALLAHAN, H. L.; CROUCH, R. K.; JAMES, E. R. Helminth Anti-oxidant Enzymes: a protective mechanism against host oxidants? Parasitology Today, v. 4, p. 218-225, 1988.

CAMPOS, E. G.; SMITH, J. M.; PRICHARD, R. K. Cytochrome c peroxidase in Schistosoma mansoni: enzyme kinetics and cellular location. Comparative Biochemistry and Physiology, v. 111, p. 371-377, 1995.

CASTRO-BORGES, W. Diversidade do Proteassoma 26S e perfil de ubiquitinação durante o desenvolvimento do parasita Schistosoma mansoni: Uma abordagem proteômica. 2005, 152 f. Tese de doutorado, apresentada à Faculdade de Medicina de Ribeirão Preto - Universidade de São Paulo, Ribeirão Preto, 2005.

CHAKRABARTI, A.; CHEN, A. W.; VARNER, J. D. A review of the mammalian unfolded protein response. Biotechnology and Bioengineering, v. 108, p. 2777-2793, 2011.

CHENG, G. F.; LIN, J. J.; FENG, X. G. et al. Proteomic analysis of differentially expressed proteins between the male and female worm of Schistosoma japonicum after pairing. Proteomics, v. 5, p. 511-521, 2005.

CHENG, C. Y.; LIN, Y. H.; SU, C. C. Curcumin inhibits the proliferation of human hepatocellular carcinoma J5 cells by inducing endoplasmic reticulum stress and mitochondrial dysfunction. International Journal of Molecular Medicine, v. 26, p. 673678, 2010.

CHENG, Y. Q.; XU, Q. M.; LI, X. R.; YANG, S. L.; ZHU-GE, H. X. In vitro evaluation of schistosomicidal potencial of curcumin against Schistosoma japonicum. Journal of Asian Natural Products Research, v. 14, p. 1064-1072, 2012.

CHITSUlO, L.; ENGELS, D.; MONTRESOR, A.; SAVIOLI, L. The global status of schistosomiasis and its control. Acta Tropica, v. 77, p. 41-51, 2000.

CHOI, H. S.; KIM, J. W.; CHA, Y. N. et al. A Quantitative Nitroblue Tetrazolium Assay for Determining Intracellular Superoxide Anion Production in Phagocytic Cells. Journal of Immunoassay and Immunochemistry, v. 27, p. 31-44, 2006.

CHONDROGIANNI, N.; GONOS, E. S. Overexpression of hUMP1/POMP proteasome accessory protein enhances a proteasome-mediated antioxidant defence. Experimental Gerontology, v. 42, p. 899-903, 2007.

CIOLI, D.; PICA-MATTOCCIA, L.; ARCHER, S. Antischistosomal drugs: past, present and future? Pharmacology Therapeutics, v. 68, p. 35-85, 1995.

CIOLI, D.; BOTROS, S. S.; WHEATCROFT-FRANCKLOW, K. et al. Determination of ED50 values for praziquantel in praziquantel-resistant and susceptible Schistosoma mansoni isolates. International Journal for Parasitology, v. 34, p. 979-987, 2004.

COE, H.; MICHALAK, M. Calcium binding chaperones of the endoplasmic reticulum. General Physiology and Biophysics, v. 28, p. F96-F103, 2009. 
COELHO, M. V. Aspectos do desenvolvimento de formas larvárias de Schistosoma mansoni em Australorbis nigricans. Revista Brasileira de Biologia, v. 17, p. 325-337, 1957.

COSTA, V.; QUINTANILHA, A.; MORADAS-FERREIRA, P. Protein oxidation, repair mechanisms and proteolysis in Saccharomyces cerevisiae. IUBMB Life, v. 59, p. 293-298, 2007.

COURA, J. R.; AMARAL, R. S. Epidemiological and Control Aspects of Schistosomiasis in Brazilian Endemic Areas. Memórias do Instituto Oswaldo Cruz, Rio de Janeiro, v. 99, suppl. I, p. 13-19, 2004.

COUX, O.; TANAKA, K.; GOLDBERG, A. L. Structure and functions of the 20S and 26S proteasomes. Annual Review Biochemistry, v. 65, p. 801-47, 1996.

CRAIG, E. A.; GAMBILL, B. D.; NELSON, R. J. Heat shock proteins: molecular chaperones of protein biogenesis. Microbiological Reviews, v. 57, p. 402-414, 1993.

CROSAS, B.; HANNA, J.; KIRKPATRICK, D. S. et al. Ubiquitin Chains Are Remodeled at the Proteasome by Opposing Ubiquitin Ligase and Deubiquitinating Activities. Cell, v. 127, p. 1401-1413, 2006.

CSIZMADIA, V.; CSIZMADIA, E.; SILVERMAN, L. et al. Effect of Proteasome Inhibitors With Different Chemical Structures on the Ubiquitin-Proteasome System In Vitro. Veterinary Pathology, v. 47, p. 358-367, 2010.

CURWEN, R. S.; ASHTON, P. D.; JOHNSTON, D. A.; WILSON, R. A. The Schistosoma mansoni soluble proteome: a comparison across four life-cycle stages. Molecular \& Biochemical Parasitology, v. 138, p. 57-66, 2004.

DALTON, T. P.; SHERTZER, H. G.; PUGA, A. Regulation of gene expression by reactive oxygen. Annual Review of Pharmacology and Toxicology, v. 39, p. 67-101, 1999.

DALY, J. W.; JACOBSON, K. A.; UKENA, D. Adenosine receptors: development of selective agonists and antagonists. Progress in Clinical and Biologic Research, v. 230, p. 41-63, 1987.

DAS, R.; ROY, A.; GANGULY, A.; DATTA, N.; MAJUNDER, H, K. Curcumin, a dietary polyphenol, emerges as a novel inhibitor of DNA topoisomerase I of kinetoplastid parasite Leishmania donovani. The Biochemical Journal, doi:10.1042/BJ20081134, 2008.

DAVIES, K. J. A. Degradation of oxidized proteins by the $20 \mathrm{~S}$ proteasome. Biochimie, v. 83, p. 301-310, 2001.

DE DIEGO, J. L.; KATZ, J. M.; MARSHALL, P. et al. The Ubiquitin-Proteasome Pathway Plays an Essential Role in Proteolysis during Trypanosoma cruzi Remodeling. Biochemistry, v. 40, p. 1053-1062, 2001.

DEMARCO, R.; VERJOVSKI-ALMEIDA, S. Schistosomes - proteomics studies for potencial novel vaccines and drug targets. Drug Discovery Today, v. 14, p. 472-478, 2009. 
DEMARTINO, G. N.; SLAUGHTER, C. A. The proteasome, a novel protease regulated by multiple mechanisms. The Journal of Biological Chemistry, v. 274, p. 22123-22126, 1999.

DEREE, J.; MARTINS, J. O.; MELBOSTAD, H.; LOOMIS, W. H.; COIMBRA, R. Insights into the regulation of TNF-alpha production in human mononuclear cells: the effects of nonspecific phosphodiesterase inhibition. Clinics, v. 63, p. 321-328, 2008.

DEWALICK, S.; BEXKENS, M. L.; BALKOM, B. W. M. V. et al. The proteome of the insoluble Schistosoma mansoni eggshell skeleton. International Journal for Parasitology, v. 41, p. 523-532, 2011.

DICK, L. R. Mechanistic studies on the inactivation of the proteasome by lactacystin in cultured cells. The Journal of Biological Chemistry, v. 272, p. 182-188, 1997.

DIEHL, J. A.; FUCHS, S. Y.; KOUMENIS, C. The cell biology of the unfolded protein response. Gastroenterology, v. 141, p. 38-41, 2011.

DIKSHIT, P.; GOSWAMI, A.; MISHRA, A.; CHATTERJEE, M.; JANA, N. R. Curcumin induces stress response, neurite outgrowth and prevent NF- $\kappa \mathrm{B}$ activation by inhibiting the proteasome function. Neurotoxicity Research, v. 9, p. 29-37, 2006.

DOYLE, V.; VIRJI, S.; GROMPTON, M. Evidence that cyclophilin-A protects cells against oxidative stress. The Biochemical Journal, v. 341, p. 127-132, 1999.

EL-ANSARY, A. Biochemical and immunological adaptation in schistosome parasitism. Comparative Biochemistry and Physiology Part B: Biochemical \& Molecular Biology, v. 136, p. 227-243, 2003.

EL-ANSARY, A. K.; AHMED, S. A.; ALY, S. A. Antischistosomal and liver protective effects of Curcuma longa extract in Schistosoma mansoni infected mice. Indian Journal Of Experimental Biology, v. 45, p. 791-801, 2007.

EL-BANHAWEY, M. A.; ASHRY, M. A.; EL-ANSARY, A. K.; ALY, S. A. Effect of Curcuma longa or praziquantel on Schistosoma mansoni infected mice liver-histological and histochemical study. . Indian Journal Of Experimental Biology, v. 45, p. 877-889, 2007.

EL-AGAMY, D. S.; SHEBI, A. M.; SAID, S. A. Prevention and treatment of Schistosoma mansoni-induced liver fibrosis in mice. Inflammopharmacology, v. 19, p. 307-316, 2011.

EMANUElE, S.; CALVARUSO, G.; LAURICELLA, M. et al. Apoptosis induced in hepatoblastoma HepG2 cells by the proteasome inhibitor MG132 is associated with hydrogen peroxide production, expression of $\mathrm{Bcl}-\mathrm{XS}$ and activation of caspase-3. International Journal of Oncology, v. 21, p. 857-865, 2002.

ENGELS, D.; CHITSUlO, L.; MONTRESOR, A.; SAVIOLI, L. The global epidemiological situation of schistosomiasis and new approaches to control and research. Acta Tropica, v. 82, p. 139-146, 2002. 
EISSA, M. M.; BARDICY, S. E.; TADROS, M. Bioactivity of miltefosine against aquatic stages of Schistosoma mansoni, Schistosoma haematobium and their snail hosts, supported by scanning electron microscopy. Parasites \& Vectors, v. 4, p. 73, 2011.

ESSAYAN, D. M. Cyclic nucleotide phosphodiesterases. The Journal of Allergy and Clinical Immunology, v. 108, p. 671-680, 2001.

FAGHIRI, Z.; SKELLY, P. J. The role of tegumental aquaporin from the human parasitic worm, Schistosoma mansoni, in osmoregulation and drug uptake. The FASEB Journal, v. 23, p. 2780-2789, 2009.

FAN, W. H.; HOU, Y.; MENG, F. K.; WANG, X. F.; LUO, Y. N.; GE, P. F. Proteasome inhibitor MG-132 induces C6 glioma cell apoptosis via oxidative stress. Acta Pharmacologica Sinica, v. 32, p. 619-625, 2011.

FANG, N. N.; NG, A. H. M.; MEASDAY, V.; MAYOR, T. Hul5 HECT ubiquitin ligase plays a major role in the ubiquitylation and turnover of cytosolic misfolded proteins. Nature Cell Biology, v. 13, p. 1344-1352, 2011.

FANG, N. N.; MAYOR, T. Hul5 ubiquitin ligase: Good riddance to bad proteins. Prion, v. 6, p. 240-244, 2012.

FERNANDES, R.; RAMALHO, J.; PEREIRA, P. Oxidative stress upregulates the ubiquitin proteassome pathaway in retinal endotelial cells. Molecular Vision, v. 12, p. 1526-1535, 2006.

FETTERER, R. H.; PAX, R. A.; BENNETT, J. L. Praziquantel, potassium and 2,4dinitrophenol: analysis of their action on the musculature of Schistosoma mansoni. European Journal of Pharmacology, v. 64, p. 31-38, 1980.

FINLEY, D. Recognition and Processing of Ubiquitin-Protein Conjugates by the Proteasome. Annual Review of Biochemistry, v. 78, p. 477-513, 2009.

FINLEY, D. Misfolded proteins driven to destruction by Hul5. Nature Cell Biology, v. 13, p. 1290-1292, 2011.

FITZPATRICK, J. M.; HIRAI, Y.; HIRAI, H.; HOFFMANN, K. F. Schistosome egg production is dependent upon the activities of two developmentally regulated tyrosinases. The FASEB Journal, v. 21, p. 823-835, 2007.

FRAPPIER, L.; VERRIJZER, C. P. Gene expression control by protein deubiquitinases. Current Opinion in Genetics \& Development, v. 21, p. 207-21, 2011.

FUNASA. Guia de vigilância epidemiológica. 5. ed. Brasília: FUNASA, 2002. 842p. v. 1.

FURTADO, D. R.; OLIVEIRA, F. M. B.; MORALES, F. C. et al. Schistosoma mansoni: SmLIMPETin, a member of a novel family of invertebrate-only regulatory proteins. Experimental Parasitology, v. 120, p. 200-204, 2008. 
FUJIMURO, M.; SAWADA, H.; YOKOSAWA, H. Dynamics of ubiquitin conjugation during heat-shock response revealed by using a monoclonal antibody specific to multiubiquitin chains. European Journal of Biochemistry, v. 249, p. 427-433, 1997.

GANTT, S. M.; MYUNG, J. M.; BRIONES, M. R. S. et al. Proteasome Inhibitors Block Development of Plasmodium spp. Antimicrobial Agents and Chemotherapy, v. 42, p. 2731-2738, 1998.

GHENDLER, Y.; ARNON, R.; FISHELSON, Z. Schistosoma mansoni: isolation and characterization of Smpi56, a novel serine protease inhibitor. Experimental Parasitology, v. 78, p. 121-131, 1994.

GIRARDINI, J. E.; KHAYATH, N.; AMIRANTE, A.; DISSOUS, C.; SERRA, E. Schistosoma mansoni: Ferredoxin-NAPD $(\mathrm{H})$ oxidoreductase and the metabolism of reactive oxygen species. Experimental Parasitology, v. 110, p. 157-161, 2005.

GLICKMAN, M. H.; RUBIN, D. M.; LARSEN, C. N.; SCHMIDT, N, FINLEY, D. The regulatory particle of the yeast proteasome. In: Proteasomes: The World of Regulatory Proteolysis, Bioscience, 2000.

GLICKMAN, M. H.; CIECHANOVER, A. The Ubiquitin-Proteasome Proteolytic Pathway: Destruction for the Sake of Construction. Physiological Reviews, v. 82, p. 373-428, 2002.

GOBERT, G. N.; STENZEL, D. J.; MCMANUS, D. P.; JONES, M. K. The ultrastructural architecture of the adult Schistosoma japonicum tegument. International Journal for Parasitology, v. 33, p. 1561-1575, 2003.

GOBERT, G. N.; CHAI, MCMANUS, D. P. Biology of the schistosome lung-stage schistosomulum. Parasitology, v. 134, p. 453-460, 2007.

GOLDBERG, A. L.; AKOPIAN, T. N.; KISSELEV, A. F. et al. New insights into the mechanisms and importance of the proteasome in intracellular protein degradation. Biological Chemistry, v. 378, p. 131-140, 1997.

GOLDRING, O. L.; CLEGG, J. A.; SMITHERS, S. R.; TERRY, R. J. Acquisition of human blood group antigens by Schistosoma mansoni. Clinical and experimental immunology, v. 26, p. 181-187, 1976.

GOURLAY, L. J.; ANGELUCCI, F.; BAIOCCO, P. et al. The three-dimensional structure of two redox states of cyclophilin A from Schistosoma mansoni. Evidence for redox regulation of peptidyl-prolyl cis-trans isomerase activity. The Journal of Biological Chemistry, v. 282, p. 24851-24857, 2007.

GROLL, M.; HUBER, R. Inhibitors of the eukaryotic $20 \mathrm{~S}$ proteasome core particle: a structural approach. Biochimica et Biophysica Acta, v. 1695, p. 33-44, 2004.

GRYSEELS, B.; POLMAN, K.; CLERINX, J.; KESTENS, L. Human schistosomiasis. Lancet, v. 368, p. 1106-1118, 2006. 
GRUNE, T.; REINHECKEL, T.; DAVIES, K. J. Degradation of oxidized proteins in mammalian cells. The FASEB Journal, v. 11, p. 526-534; 1997.

GRUNE, T.; JUNG, T.; MERKER, K.; DAVIES, K. J. Decreased proteolysis caused by protein aggregates, inclusion bodies, plaques, lipofuscin, ceroid, and "aggresomes" during oxidative stress, aging, and disease. The International Journal of Biochemistry \& Cell Biology, v. 36, p. 2519-2530, 2004.

GRUNE, T.; CATALGOL, B.; LICHT, A. et al. HSP70 mediates dissociation and reassociation of the $26 \mathrm{~S}$ proteasome during adaptation to oxidative stress. Free Radical Biology \& Medicine, v. 51, p. 1355-1364, 2011.

GREENBERG, R. M. Are $\mathrm{Ca}^{2+}$ channels targets of praziquantel action? Internacional Journal for Parasitology, v. 35, p. 1-9, 2005.

GUERRA-SÁ, R. (2000). Sequenciamento e caracterização de cDNAs codificando para a cadeia leve da miosina, desidrogenase láctica e poliubiquitina em $\boldsymbol{S}$. mansoni. $220 \mathrm{f}$. Tese de Doutorado, apresentada à Faculdade de Medicina de Ribeirão Preto-Universidade de São Paulo, Ribeirão Preto, 2000.

GUERRA-SÁ, R.; CASTRO-BORGES, W.; EVANGELISTA, E. A.; KETTELHUT, I. C.; RODRIGUES, V. Schistosoma mansoni: Functional proteasomes are required for development in the vertebrate host. Experimental Parasitology, v. 109, p. 228-236, 2005.

GUI, M.; KUSEL, J. R.; SHI, R. E.; RUPPEL, A. Schistosoma japonicum and S. mansoni: comparison of larval migration patterns in mice. Journal of Helminthology, v. 69, p. 19-25, 1995.

GUILlOU, F.; ROGER, E.; MONÉ, Y. et al. Excretory-secretory proteome of larval Schistosoma mansoni and Echinostoma caproni, two parasites of Biomphalaria glabrata. Molecular \& Biochemical Parasitology, v. 155, p. 45-56, 2007.

HAHN, U. K.; BENDER, R. C.; BAYNE, C. J. Killing of Schistosoma mansoni sporocysts by hemocytes from resistant Biomphalaria glabrata: role of reactive oxygen species. The Journal of Parasitology, v. 87, p. 292-299, 2001.

HAN, S. S.; KEUM, Y. S.; SEO, H. J.; SURH, Y. J. Curcumin suppresses activation of NFkappaB and AP-1 induced by phorbol ester in cultured human promyelocytic leukemia cells. Journal of Biochemistry and Molecular Biology, v. 35, p. 337-342, 2002.

HAN, Y. H.; MOON, H. J.; YOU, B.; PARK, W. H. The effect of MG132, a proteasome inhibitor on HeLa cells in relation to cell growth, reactive oxygen species and GSH. Oncology Reports, v. 22, p. 215-221, 2009.

HAN, Y. H.; YANG, Y. M.; KIM, S. Z.; PARK, W. H. Attenuation of MG132-induced HeLa Cell Death by N-Acetyl Cysteine via Reducing Reactive Oxygen Species and Preventing Glutathione Depletion. Anticancer Research, v. 30, p. 2107-2112, 2010. 
HAN, H.; PENG, J.; HONG, Y. et al. Molecular cloning and characterization of a cyclophilin A homologue from Schistosoma japonicum. Parasitology Research, v. 111, p. 807-817, 2012.

HANNA, J.; HATHAWAY, N. A.; TONE, Y. Et al. Deubiquitinating Enzyme Ubp6 Functions Noncatalytically to Delay Proteasomal Degradation. Cell, v. 127, p. 99-111, Oct., 2006.

HANNA, J.; MEIDES, A.; PHOEBE, D.; ZHANG, D. P.; FINLEY, D. A Ubiquitin Stress Response Induces Altered Proteasome Composition. Cell, v. 129, p. 747-759, 2007.

HANNA, J.; FINLEY, D. A proteasome for all occasions. FEBS Letters, v. 581, p. 28542861, 2007.

HARDER, A.; GOOSSENS, J.; ANDREWS, P. Influence of praziquantel and $\mathrm{Ca}^{2+}$ on the bilayer-isotropic-hexagonal transition of model membranes. Molecular and Biochemical Parasitology, v. 29, p. 55-60, 1988.

HARNETT, W.; KUSEL, J. R. Increased exposure of parasite antigens at the surface of adult male Schistosoma mansoni exposed to praziquantel in vitro. Parasitology, v. 93, p. 401-405, 1986.

HARROP, R.; WILSON, R. A. Protein synthesis an release by cultures schistosomula of Schistosoma mansoni. Parasitology, v. 107, p. 265-274, 1993.

HATCHER, H.; PLANALPB, R.; CHOB, J. et al. Curcumin: From ancient medicine to current clinical trials. Cellular and Molecular Life Sciences, v. 65, p. 1631-1652, 2008.

HATZIMOURATIDIS, K.; BURNETT, A. L.; HATZICHRISTOU, D. et al. Phosphodiesterase type 5 inhibitors in postprostatectomy erectile dysfunction: A critical analysis of the basic science rationale and clinical application. European Urology, v. 55, p. 334-347, 2009.

HE, Y. X.; CHEN, L.; RAMASWAMY, K. Schistosoma mansoni, S. haematobium, and S. japonicum: early events associated with penetration and migration of schistosomula through hum skin. Experimental Parasitology, v. 102, p. 99-108, 2002.

HELLEMOND, J. J. V.; RETRA, K.; BROUWERS, J. F. H. M. et al. Functions of the tegument of schistosomes: Clues from the proteome and lipidome. International Journal for Parasitology, v. 36, p. 691-699, 2006.

HERSHKO, A.; CIECHANOVER, A. The ubiquitin system. Annual Review Biochemistry, v. 67, p. 425-79, 1998.

HILLE, B. Ion channels of excitable membranes. Third edition. Sinauer Associates, Inc., Sunderland, MA. 814p, 2001.

HOCKLEY, D. J. Ultrastructure of the tegument of Schistosoma. Advances in Parasitology, v. 11, p. 233-305, 1973. 
HOFFMANN, W. A; PONS, J. A; JANER, J. L. The sedimentation concentration method in schistosomiasis mansoni. The Puerto Rico Journal of Public Health and Tropical Medicine, v. 9, p. 283-291, 1934.

HONG, Z.; LOVERDE, P. T.; HAMMARSKJÖLD, M. L.; REKOSH, D. Schistosoma mansoni: cloning of a complementary DNA encoding a cytosolic $\mathrm{Cu} / \mathrm{Zn}$ superoxide dismutase and high-yield expression of the enzymatically active gene product in Escherichia coli. Experimental Parasitology, v. 75, p. 308-322, 1992a.

HONG, Z.; KOSMAN, D. J.; THAKUR, A. et al. Identification and purification of a second form of $\mathrm{Cu} / \mathrm{Zn}$ superoxide dismutase from Schistosoma mansoni. Infection and Immunity, v. 60 , p. 3641-3651, 1992 b.

HUOT, J.; HOULE, F.; MARCEAU, F.; LANDRY, J. Oxidative stress-induced actin reorganization mediated by the p38 mitogen-activated protein kinase/heat shock protein 27 pathway in vascular endothelial cells. Circulation Research, v. 3, p. 383-392, 1997.

ISHII, M.; SHIMIZU, S.; HARA, Y. et al. Intracellular-produced hydroxyl radical mediates $\mathrm{H}_{2} \mathrm{O}_{2}$-induced $\mathrm{Ca}^{2+}$ influx and cell death in rat $\beta$-cell line RIN-5F. Cell Calcium, v. 39, p. 487-494, 2006.

ISMAIL, M.; BOTROS, S.; METWALLY, A. et al. Resistance to praziquantel: direct evidence from Schistosoma mansoni isolated from Egyptian villagers.American Society of Tropical Medicine and Hygiene, v. 60, p. 932-935, 1999.

JAKOB, U.; MUSE, W.; ESER, M.; BARDWELL, J. C. A. Chaperone activity with a Redox Switch. Cell, v. 96, p. 341-352, 1999.

JANA, N. R.; DIKSHIT, P.; GOSWAMI, A.; NUKINA, N. Inhibition of proteasomal function by curcumin induces apoptosis through mitochondrial pathway. The Journal of Biological Chemistry, v. 279, p. 11680-11685, 2004.

JANTSCHITSCH, C.; TRAUTINGER, F. Heat shock and UV-B-induced DNA damage and mutagenesis in skin. Photochemical \& Photobiological Science, v. 2, p. 899-903, 2003.

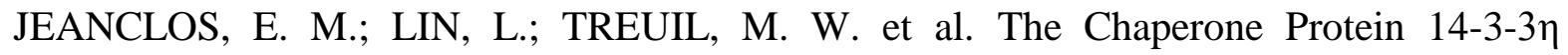
Interacts with the Nicotinic Acetylcholine Receptor $\alpha 4$ Subunit. The Journal of Biological Chemistry, v. 276, p. 28281-28290, 2001.

JIA, L.; XU, M.; ZHEN, W. et al. Novel anti-oxidative role of calreticulin in protecting A549 human type II alveolar epithelial cells against hypoxic injury. American Journal of Physiology-Cell Physiology, v. 294, p. C47-C55, 2008.

JUNG, T.; BADER, N.; GRUNE, T. Oxidized proteins: Intracellular distribution and recognition by the proteasome. Archives of Biochemistry and Biophysics, v. 462, p. 231 $237,2007$.

JUNG, T.; CATALGOL, B.; GRUNE, T. The proteassomal system. Molecular Aspects of Medicine, v. 30, p. 191-296, 2009. 
KACZOROWKI, G. J.; MCMANUS, O. B.; PRIEST, B. T.; GARCIA, M. L. Ion channels as drug targets: The next GPCRs. The Journal of General Physiology, v. 131, p. 399-405, 2008.

KADRMAS, J. L.; BECKERLE, M. C. The LIM domain: from the cytoskeleton to the nucleus. Nature Reviews: Molecular Cell Biology, v. 5, p. 920-931, 2004.

KALMAR, B.; GREENSMITH, L. Induction of heat shock proteins for protection against oxidative stress. Advanced Drug Delivery Reviews, v. 61, p. 310-318, 2009.

KAPP, K.; COUSTAU, C.; WIPPERSTEG, V.; JOURDANE, J. et al. Transplantation of in vitro-generated Schistosoma mansoni mother sporocysts into Biomphalaria glabrata. Parasitology Research, v. 91, p. 482-485, 2003.

KASTLE, M.; GRUNE, T. Protein oxidative modification in the aging organism and the role of the ubiquitin proteasomal system. Current Pharmaceutical Design, v. 17, p. 4007-4022, 2011.

KASTLE, M.; GRUNE, T. Interactions of the proteasomal system with chaperones: Protein triage and protein quality control. In: GRUNE, T. Progress in Molecular Biology and Translational Science, v. 109, Burlington: Academic Press., p. 113-160, 2012.

KATSCHINSKI, D. M. On heat and cells and proteins. News in Physiological Sciences, v. 19, p. 11-15, 2004.

KEISER, J.; MANNECK, T.; VARGAS, M. Interactions of mefloquine with praziquantel in the Schistosoma mansoni mouse model and in vitro. Journal of Antimicrobial Chemotherapy, v. 66, p. 1791-1797, 2011.

KHAN, S.; HEIKKILA, J. J. Curcumin-induced inhibition of proteasomal activity, enhanced HSP accumulation and the acquisition of thermotolerance in Xenopus laevis A6 cells. Comparative Biochemistry and Physiology, v. 158, p. 566-576, 2011.

KIM, J. H.; PARK, K. C.; CHUNG, S. S.; BANG, O.; CHUNG, C. H. Deubiquitinating enzymes as cellular regulators. Journal of Biochemistry, v. 134, p. 9-18, 2003.

KING, C.H., DICKMAN, K., TISCH, D.J. Reassessment of the cost of chronic helmintic infection: a meta-analysis of disability-related outcomes in endemic schistosomiasis. Lancet, v. 365, p. 1561-1569, 2005.

KING, C. H. Toward the elimination of schistosomiasis. The New England Journal of Medicine, v. 360, p. 106-109, 2009.

KOEGL, M.; HOPPE, T.; SCHLENKER, S.; ULRICH, H. D. et al. A Novel Ubiquitination Factor, E4, Is Involved in Multiubiquitin Chain Assembly. Cell, v. 96, p. 635-644, 1999.

KOIDE, T.; NOSE, M.; OGIHARA, Y.; YABU, Y.; OHTA, N. Leishmanicidal effect of Curcumin in vitro. Biological \& Pharmaceutical Bulletin, v. 25, p. 131-133, 2002. 
KOMANDER, D.; CLAGUE, M. J.; URBE, S. Breaking the chains: structure and function of the deubiquitinases. Molecular cell Biology, v. 10, p. 550-563, 2009.

KOPP, F.; DAHLMANN, B.; HENDIL, K. B. Evidence indicating that the human proteasome is complex dimer. Journal of Molecular Biology, v. 229, p. 14-19, 1993.

KORENNYKH, A.; WALTER, P. Structural basis of the unfolded protein response. Annual Review of Cell and Developmental, v. 28, p. 251-277, 2012.

KOSTOVA, Z.; WOLF, D. H. For whom the bell tolls: protein quality control of the endoplasmic reticulum and the ubiquitin-proteasome connection. The EMBO Journal, v. 22, p. 2309-2317, 2003.

KRAUSE, K. H.; MICHALAK, M. Calreticulin. Cell, v. 88, p. 439-443, 1997.

KRAUT, D. A.; PRAKASH, S.; MATOUSCHEK, A. To degrade or release: ubiquitin-chain remodeling. Trends in Cell Biology, v. 17, p. 419-421, 2007.

KRIEGENBURG, F.; POULSEN, E. G.; KOCH, A. et al. R. Redox Control of the Ubiquitin-Proteasome System: From Molecular Mechanisms to Functional Significance. Antioxidants \& Redox Signaling, v. 15, p. 2265-2299, 2011.

KUHAR, M.; IMRAN, S.; SINGH, N. Curcumin and quercetin combined with cisplatin to induce apoptosis in human laryngeal carcinoma hep-2 cells through the mitochondrial pathway. Journal of Cancer Molecules, v. 3, p. 121-128, 2007.

KULTZ, D. Molecular and evolutionary basis of the cellular stress response. Annual Review of Physiology, v. 67, p. 225-257, 2005.

KUNTZ, A. N; DAVIOUD-CHARVET, E.; SAYED, A. A.; CALIFF, L. L. et al. Thioredoxin glutathione reductase from Schistosoma mansoni: an essential parasite enzyme and a key drug target. PloS Medicine, v. 4, p. 1071-1086, 2007.

LAClETTE, J. P.; SHOEMAKER, C. B.; RICHTER, D. et al. Paramyosin inhibits complement C1. Journal of immunology, v. 148, p. 124-8, 1992.

LANDIS-PIWOWAR, K. R.; MILACIC, V.; CHEN, D. et al. The proteasome as a potential target for novel anticancer drugs and chemosensitizers. Drug Resistance Updates, v. 9, p. 263-273, 2006.

LEDERKREMER, G. Z .Glycoprotein folding, quality control and ER-associated degradation. Current Opinion in Structural Biology, v. 19, p. 515-523, 2009.

LEE, J. W.; HONG, H. M.; KWON, D. D. et al. Dimethoxycurcumin, a Structural Analogue of Curcumin, Induces Apoptosis in Human Renal Carcinoma Caki Cells Through the Production of Reactive Oxygen Species, the Release of Cytochrome c, and the Activation of Caspase-3. Korean Journal of Urology, v. 51, p. 870-878, 2010.

LEGGETT, D. S.; HANNA, J.; BORODOVSKY, A. et al. Multiple Associated Proteins Regulate Proteasome Structure and Function. Molecular Cell, v. 10, p. 495-507, 2002. 
LIMA, S. F.; VIEIRA, L. Q.; HARDER, A.; KUSEL, J. Effects of culture and praziquantel on membrane fluidity parameters of adult Schistosoma mansoni. Parasitology, v. 109, p. 57-64, 1994.

LINGDAN, L.; PENGTAO, G.; WENCHAO, L. et al. Differential dissolved protein expression throughout the life cycle of Giardia lamblia. Experimental Parasitology, v. 132, p. 465-469, 2012.

LIVAK, K. J.; SCHMITTGEN, T. D. Analysis of relative gene expression data using realtime quantitative PCR and the 2(T)(-Delta Delta C) method. Methods, v. 25, p. 402-408, 2001.

LOIDL, G.; GROLL, M.; MUSIOL, H. J. et al. Bivalency as a principle for proteasome inhibition. Proceedings of the National Academy of Sciences, v. 96, p. 5418-5422, 1999.

LOVERDE, P. T. Do antioxidants play a role in schistosome host-parasite interactions? Parasitology Today, v. 14, p. 284-289, 1998.

LIN, S. S.; HUANG, H. P.; YANG, J. S. et al. DNA damage and endoplasmic reticulum stress mediated curcumin-induced cell cycle arrest and apoptosis in human lung carcinoma A-549 cells through the activation caspases cascade- and mitochondrial-dependent pathway. Cancer Letters, v. 272, p. 77-90, 2008.

LING, Y. H.; LIEBES, L.; ZOU, Y.; PEREZ-SOLER, R. Reactive oxygen species generation and mitochondrial dysfunction in the apoptotic response to Bortezomib, a novel proteasome inhibitor, in human H460 non-small cell lung cancer cells. The Journal of Biological Chemistry, v. 278, p. 33714-33723, 2003.

LIU, H.; BOWES, R. C.; VAN DE WATER et al. Endoplasmic Reticulum Chaperones GRP78 and Calreticulin Prevent Oxidative Stress, $\mathrm{Ca}^{2+}$ Disturbances, and Cell Death in Renal Epithelial Cells. The Journal of Biological Chemistry, v. 272, p. 21751-21759, 1997.

LIU, F.; LU, J. HU, W. et al. New perspectives on host-parasite interplay by comparative transcriptomic and proteomic analyses of Schistosoma japonicum. PLOS Pathogenes, v. 2, p. 268-281, 2006.

LIU, F.; CUI, S. J.; HU, W.; FENG, Z. et al. Excretory/Secretory proteome of the adult developmental stage of human blood fluke, Schistosoma japonicum. Molecular \& Cellular Proteomics, v. 8, p. 1236-1251 2009.

LUZ, P. P.; MAGAlHAES, L. G.; PEREIRA, A. C. et al. Curcumin-loaded into PLGA nanoparticles: Preparation and in vitro schistosomicidal activity. Parasitology Research, v. 110, p. 593-598, 2012.

MACCONNACHIE, A. Schistosomiasis. The journal of the Royal College of Physicians of Edinburgh, v. 42, p. 47-49, 2012.

MACHADO-SILVA, J. R.; NEVES, R. H.; GOMES, D. C. Filogenia, Co-evolução, aspectos morfológicos $\mathrm{e}$ biológicos das diferentes fases de desenvolvimento de 
Schistosoma mansoni. In: Schistosoma mansoni \& Esquistossomose: uma visão multidisciplinar. Fiocruz, 2008.

MAGALHAES, B. F.; DIAS, C. B. Esquistossomose de Manson - Estudos. Memórias do Instituto Oswaldo Cruz, v. 41, p. 363-446, dez., 1944.

MAGALHAES, L. G.; BOTELHO-MACHADO, C.; MORAIS, E. R. et al. In vitro schistosomicidal activity of curcumin against Schistosoma mansoni adult worms. Parasitology Research, v. 104, p. 1197-1201, 2009.

MAGALHAES, L. G. Via Notch em Schistosoma mansoni: Aspectos moleculares e funcionais. 2009, 195 p. Tese de doutorado, apresentada à Faculdade de Medicina de Ribeirão Preto - Universidade de São Paulo, Ribeirão Preto, 2009.

MAHESHWARI, R. K.; SINGH, A. K.; GADDIPATI, J.; SRIMAL, R. C. Multiple biological activities of curcumin: a short review. Life Science, v. 78, n. 18, p. 2081-2087, 2006.

MALMENDAL, A.; OVERGAARD, J.; BUNDY, J. G. et al. Metabolomic profiling of heat stress: hardening and recovery of homeostasis in Drosophila. American Journal of Physiology - Regulatory, Integrative and Comparative Physiology, v. 291, p. R205-212, 2006.

MARCU, M. G.; DOYLE, M.; BERTOLOTTI, A. et al. Heat Shock protein 90 modulates the unfolded protein response by stabilizing IRE1 $\alpha$. Molecular and Cellular Biology, v. 22, p. 8506-8513, 2002.

MARÍN-MENÉNDEZ, A.; MONAGHAN, P.; BELL, A. A family of cyclophilin-like molecular chaperones in Plasmodium falciparum. Molecular and Biochemical Parasitology, v. 184, p. 44-47, 2012.

MARQUES, L. J.; ZHENG, L.; POULAKIS, N. et al. Pentoxifylline inhibits TNF-alpha production from human alveolar macrophages. American Journal of Respiratory and Critical Care Medicine, v. 159, p. 508-511, 1999.

MARQUES, C.; GUO, W.; PEREIRA, P.; TAYLOR, A. et al. The triage of damaged proteins: degradation by the ubiquitin-proteasome pathway or repair by molecular chaperones. The FASEB Journal, v. 20, p. 741-743, 2006.

MARTINS JÚNIOR, D. F.; BARRETO, M. L. Aspectos macroepidemiológicos da esquistossomose mansônica: análise da relação da irrigação no perfil espacial da endemia no Estado da Bahia, Brasil. Caderno de Saúde Pública, Rio de Janeiro, v. 19, n. 2, p. 383-393, mar./abr., 2003.

MAUL, R. S.; SONG, Y.; AMANN, K. J. et al. EPLIN regulates actins dynamics by crosslinking and stabilizing filaments. The Journal of Cell Biology, v. 160, p. 399-407, 2003.

MAYER, M. P. Gymnastics of molecular chaperones. Molecular Cell, v. 39, p. 321-331, 2010. 
McDONALD, C. J.; JONES, M. K.; WALLACE, D. F. et al. Increased Iron Stores Correlate with Worse Disease Outcomes in a Mouse Model of Schistosomiasis Infection. Plos One, v. 5, e. 9594, 2010.

McGONIGLE, S.; BEALL, M. J. et al. Conserved role for 14-3-3 epsilon downstream of type I TGFbeta receptors. FEBS Letters, v. 490, p. 65-69, 2001.

MEARES, G. P.; ZMIJEWSKA, A. A.; JOPE, R. S. HSP105 interacts with GRP78 and GSK3 and promotes ER stress-induced caspase-3 activation. Cellular Signalling, v. 20, p. 347-358, 2008.

MENG, L.; KWOK, B. H.; SIN, N.; CREWS, C. M. Eponemycin exerts its antitumor effect through the inhibition of proteasome function. Cancer Research, v. 59, p. 2798-2801, 1999a.

MENG, L.; MOHAN, R.; KWOK, B. H. et al. Epoxomicin, a potent and selective proteasome inhibitor, exhibits in vivo anti-inflammatory activity. Proceedings of the National Academy of Sciences, v. 96, p. 10403-10408, 1999 b.

MICHALAK, M.; CORBETT, E. F.; MESAELI, N. et al. Calreticulin: one protein M, one gene, many functions. The Biochemical Journal, v. 344, p. 281-292, 1999.

MILACIC, V.; BANERJEE, S.; LANDIS-PIWOWAR, K. R. et al. Curcumin inhibits the proteasome activity in Human Colon Cancer Cells in vitro and in vivo. Cancer Research, v. 68, p. 7283-7292, 2008.

MKOJI, G. M.; SMITH, J. M.; PRICHARD, R. K. Antioxidant systems in Schistosoma mansoni: Correlation between susceptibility to oxidant killing and the levels of scavengers of hydrogen peroxide and oxygen free radicals. International Journal for Parasitology, v. 18, p. 661-666, 1988.

MOORE, D. V.; SANDGROUND, J. H. The relative egg producing capacity of Schistosoma mansoni and Schistosoma japonicum. American Society of Tropical Medicine and Hygiene, v. 5, p. 831-840, 1956.

MORAIS, E. R. (2009). Clonagem, expressão e caracterização molecular e funcional da subunidade Rpn10 do proteassoma de Schistosoma mansoni. 123p. Dissertação de Metrado, apresentada à Faculdade de Medicina de Ribeirão Preto - Universidade de São Paulo, Ribeirão Preto, 2009.

MORAIS, E. R. (2012). Avaliação dos efeitos de Curcumina e MG132 sobre o parasita Schistosoma mansoni. 116p. Tese de doutorado, apresentada à Faculdade de Medicina de Ribeirão Preto - Universidade de São Paulo, Ribeirão Preto, 2012.

MORAIS, E. R.; OLIVEIRA, K. C.; MAGALHAES, L. G. et al. Effects of curcumin on the parasite Schistosoma mansoni: A transcriptomic approach. Molecular \& Biochemical Parasitology. Article in press. 2013.

MOREIRA, E. B. C. Influência de mediadores químicos e físicos na modelagem estrutural e funcional do proteassoma de Schistosoma mansoni. 2008, 122p. Dissertação 
de Mestrado, apresentada à Faculdade de Medicina de Ribeirão Preto - Universidade São Paulo, Ribeirão Preto, 2008.

MORIMOTO, R. I. Proteotoxic stress and inducible chaperone networks in neurodegenrative disease and aging. Genes \& Development, v. 22, p. 1427-1438, 2008.

MOSKOVITZ, J. Methionine sulfoxide reductases: ubiquitous enzymes involved in antioxidant defense, protein regulation, and prevention of aging-associated diseases. Biochimica et Biophysica Acta, v. 1703, p. 213-219, 2005.

MOSTAFA, O. M. S.; EID, R. A.; ADLY, M. A. Antischistosomal activity of ginger (Zingiber officinale) against Schistosoma mansoni harbored in C57 mice. Parasitology Research, v. 109, p. 395-403, 2011.

MOURÃO, M. M.; DINGUIRARD, N.; FRANCO, G. R.; YOSHINO, T. P. Phenotypic Screen of Early-Developing Larvae of the Blood Fluke, Schistosoma mansoni, using RNA Interference. PLOS Neglected Tropical Diseases, 3(8): e502. doi:10.1371/journal.pntd.0000502, August, 2009.

MURATA, S.; MINAMI, Y.; MINAMI, M. et al. CHIP is chaperone-dependent E3 ligase that ubiquitylates unfolded protein. EMBO Reports, v. 21, p. 1133-1138, 2001.

NAGAJYOTHI, F.; ZHAO, D.; WEISS, L. M.; TANOWITZ, H. B. Curcumin treatment provides protection against Trypanosoma cruzi infection. Parasitology Research, v. 110, p. 2491-2499, 2012.

NARE, B.; SMITH, J. M.; PRICHARD, R. K. Schistosoma mansoni: levels of antioxidants and resistance to oxidants increase during development. Experimental Parasitology, v. 70, p. 389-397, 1990.

NATALE, M.; MARESCA, B.; ABRESCIA, P.; BUCCI, E. M. Image Analysis Workflow for 2-D Electrophoresis gels based on ImageJ. Proteomic Insights, v. 4, p. 37-49, 2011.

NAYAK, A.; GAYEN, P.; SAINI, P.; MUKHERJEE, N.; BABU, S. P. S. Molecular evidence of curcumin-induced apoptosis in the filarial worm Setaria cervi. Parasitology Research, v. 111, p. 1173-1186, 2012.

NEVES, J. K. A. L.; LIMA, M. C. A.; PEREIRA, V. R. A. et al. Antischistosomal action of thioxo-imidazolidine compounds: An ultrastructural and cytotoxicity study. Experimental Parasitology, v. 128, p. 82-90, 2011.

NAUJOKAT, C.; FUCHS, D.; BERGES, C. Adaptive modification and flexibility of the proteasome system in response to proteasome inhibition. Biochimica et Biophysica Acta, v. 1773, p. 1389-1397, 2007.

NIJMAN, S. M. B.; LUNA-VARGAS, M. P. A.; VELDS, A. et al. Genomic and Functional Inventory of Deubiquitinating Enzymes. Cell, v. 123, p. 773-786, 2005. 
NKEMGU-NJINKENG, J.; ROSENKRANZ, V.; WINK, M.; STEVERDING, D. Antitrypanossomal activities of proteasome inhibitors. Antimicrobial Agents and Hemotherapy, v. 46, p. 2038-2040, 2002.

NOSE, M; KOIDE, T.; OGIHARA, Y. et al. Trypanocidal effects of curcumin in vitro. Biological \& Pharmaceutical Bulletin, v. 21, p. 643-645, 1998.

OLSON, P. D.; CRIBB, T. H.; TKACH, V. V.; BRAY, R. A. et al. Phylogeny and classification of the Digenea (Platyhelminthes: Trematoda). International Journal for Parasitology, v. 33, p. 733-755, 2003.

OKE, T. T.; MOSKOVITZ, J.; WILliAMS, D. L. Characterization of the Methionine sulfoxide reductases of Schistosoma mansoni. Journal of Parasitology, v. 95, p. 1421-1428, 2009.

OYADOMARI, S.; YUN, C.; FISHER, E. A. et al. Cotranslocational degradation protects the stressed endoplasmic reticulum from protein overload. Cell, v. 126, p. 727-739, 2006.

PAN, S. C. Schistosoma mansoni: the ultrastructure of larval morphogenesis in Biomphalaria glabrata and of associated host-parasite interactions. Japanese Journal of Medical Science \& Biology, v. 49, p. 129-149, 1996.

PARAENSE, W. L. Distribuição dos caramujos no Brasil. Modernos conhecimentos sobre esquistossomose mansônica no Brasil. Biblioteca da Academia Mineira de Medicina, v. 14, p. 117-128, 1986.

PARIZADE, M.; ARNON, R.; LACHMANN, P. J.; FISHELSON, Z. Functional and antigenic similarities between a $94-\mathrm{kD}$ protein of Schistosoma mansoni (SCIP-1) and human CD59. The Journal of experimental medicine, v. 179, p. 1625-1636, 1994.

PARK, B. J.; LEE, D. G.; YU, J. R. et al. Calreticulin, a Calcium-binding Molecular Chaperone, Is Required for Stress Response and Fertility in Caenorhabditis elegans. Molecular Biology of the Cell, v. 12, p. 2835-2845, 2001.

PARK, S.; KIM, W.; TIAN, G. et al. Structural defects in the regulatory particle-core particle interface of the proteasome induce a novel proteasome stress response. The Journal of Biological Chemistry, v. 286, p. 36652-36666, 2011.

PARSELL, D. A.; LINDQUIST, S. The function of heat-shock proteins in stress tolerance: degradation and reactivation of damaged proteins. Annual Reviews of Genetics, v. 27, p. 437-496, 1993.

PASSOS, A. D. C.; SIlleIRA, A. C.; MADRUGA, J. P. et al. Controle da esquistossomose: diretrizes técnicas. 2. ed. Brasília: Ministério da Saúde: Fundação Nacional de Saúde, 70p. 1998.

PEARCE, E. J.; HALL, B. F.; SHER, A. Host-specific evasion of the alternative complement pathway by schistosomes correlates with the presence of a phospholipase Csensitive surface molecule resembling human decay accelerating factor. Journal of immunology, v. 144, p. 2751-2756, 1990. 
PEARCE, E. J.; MACDONALD, A. S. The immunobiology of schistosomiasis. Nature Reviews Immunology, v. 2, p. 499-511, 2002.

PELLEGRINO, J.; COELHO, P. M. Schistosoma mansoni: wandering capacity of a worm couple. The Journal of parasitology, v. 64, p. 181-182, 1978.

PEREIRA, A. S.; PADILHA, R. J.; LIMA-FILHO, J. L.; CHAVES, M. E. Scanning electron microscopy of the human low-density lipoprotein interaction with the tegument of Schistosoma mansoni. Parasitology Research, v. 109, p. 1395-1402, 2011.

PÉREZ-ARRIAGA, L.; MENDOZA-MAGAÑA, M. L.; CORTÉS-ZÁRATE, R. et al. Cytotoxic effect of curcumin on Giardia lamblia trophozoites. Acta Tropica, v. 98, p. 152$161,2006$.

PESSOA, S. B. Parasitologia Médica. 7. ed. Rio de Janeiro: Guanabara Koogan S.A., 1969. 943p.

PETERS-GOLDEN, M.; CANETTI, C.; MANCUSO, P.; COFFEY, M. J. Leukotrienes: underappreciated mediators of innate immune responses. Journal of Immunology, v. 174, p. 589-94, 2005.

PICKART, C. M. Mechanisms Underlying Ubiquitination. Annual Review Biochemistry, v. 70, p. 503-533, 2001.

PICKART, C. M.; EDDINS, M. J. Ubiquitin: structures, functions, mechanisms. Biochimica et Biophysica Acta, v. 1695, p. 55-72, 2004.

PICKETT, J. A proteasome for every occasion. Molecular Cell Biology, v. 8, 2007.

PIOTUKH, K.; GU, W.; KOFLER, M. et al. Cyclophilin A binds to linear peptide motifs containing a consensus that is present in many human proteins. The Journal of Biological Chemistry, v. 280, p. 23668-23674, 2005.

PRATA, A. Comemoração do centenário da descoberta do Schistosoma mansoni no Brasil. Revista da Sociedade Brasileira de Medicina Tropical, v. 41, p. 689-691, 2008.

QIU, J. H.; ASAI, A.; CHI, S. et al. Proteasome inhibitors induce cytochrome c-caspase-3like protease-mediated apoptosis in cultured cortical neurons. The Journal of Neuroscience, v. 20, p. 259-265, 2000.

RAAMSDONK, J. M. V.; HEKIMI, S. Reactive oxygen species and aging in Caenorhabditis elegans: causal or casual relationship? Antioxidants \& Redox Signaling, v. 13, p. 1911-1953, 2010.

RAJESWARI, A. Curcumin protects mouse brain from oxidative stress caused by 1-methyl4-phenyl-1,2,3,6-tetrahydro pyridine. European Review for Medical and Pharmacological Sciences, v. 10, p. 157-161, 2006. 
RAMALHO-PINTO, F. J.; GAZZINELLI, G.; HOWELLS, R. E.et al. Schistosoma mansoni: defined system for stepwise transformation of cercaria to schistosomule in vitro. Experimental Parasitology, v. 36, p. 360-372, 1974.

RECHSTEINER, M.; HILL, C. P. Mobilizing the proteolytic machine: cell biological roles of proteasome activators and inhibitors. Trends in Cell Biology, v. 15, p. 27-33, 2005.

REDDY, P. A.; ATREYA, C. D. Identification of simian cyclophilin A as a calreticulinbinding protein in yeast two-hybrid screen and demonstration of cyclophilin A interaction with calreticulin. International Journal of Biological Macromolecules, v. 25, p. 345-351, 1999.

REDMAN, C. A.; ROBERTSON, A.; FALLON, P. G. et al. Praziquantel: an urgent and exciting challenge. Parasitology Today, v. 12, p. 14-20, 1996.

REY, L. Parasitologia. Parasitos e doenças parasitárias do homem nas Américas de na África. 3. ed. Rio de Janeiro: Guanabara Koogan S.A., 2001. 856p.

REYES-TURCU, F. E.; VENTII, K. H.; WILKINSON, K. D. Regulation and Cellular Roles of Ubiquitin-Specific Deubiquitinating Enzymes. Annual Review of Biochemistry, v. 78, p. 363-397, 2009.

RICHTER, K.; HASLBECK, M.; BUCHNER, J. The Heat Shock Response: Life on the Verge of Death. Molecular Cell, v. 40, p. 253-266, 2010.

RICHARDSON, P. G.; MITSIADES, C.; HIDESHIMA, T.; ANDERSON, K. C. BORTEZOMIB: Proteasome inhibition as an effective anticancer therapy. Annual Review of Medicine, v. 57, p. 33-47, 2006.

ROBERTSON, C. D. The Leishmania mexicana proteasome. Molecular and Biochemical Parasitology, v. 103, p. 49-60, 1999.

RODRIGUES, A. L.; LOUZADA, M. C. Boletim Epidemiológico: A Experiência no Controle da Esquistossomose no Estado do Espírito Santo (2000 a 2002). ano 3, v. 3, n. 3-4, jul./dez., 2003.

ROZEN, S.; SKALETSKY, H. J. Primer3 on the WWW for general users and for biologist programmers._In: KRAWETZ, S.; MISENER, S. (eds) Bioinformatics Methods and Protocols: Methods in Molecular Biology. Humana Press, Totowa, NJ, p. 365-386, 2000.

RUBY, A. J.; KUTTAN, G.; BABU, K. D.; RAJASEKHARAN, K. N. Anti-tumor and antioxidant activity of natural curcuminoids. Cancer Letters, v. 94, p. 79-83, 1995.

RUPPEL, A.; MCLAREN, D. J. Schistosoma mansoni: surface membrane stability in vitro and in vivo. Experimenal Parasitology, v. 62, p. 223-236, 1986.

SALOMONS, F. A.; ACS, K.; DANTUMA, N. P. Illuminating the ubiquitin/proteasome system. Experimental Cell Research, v. 316, p. 1289-1295, 2010. 
SAKATA, E.; STENGEL, F.; FUKUNAGA, K. et al. The catalytic activity of Ubp6 enhances maturation of the proteasomal regulatory particle. Molecular Cell, v. 42, p. 637649, 2011.

SANGER, F.; NICKLEN, S.; COULSON, A. R. DNA sequencing with chain terminating inhibitors. Proceedings of the National Academy of Sciences of the United States of America, v. 74, p. 5463-5467, 1977.

SANTOS, C. X.; TANAKA, L. Y.; WOSNIAK, J.; LAURINDO, F. R. Mechanisms and implications of reactive oxygen species generation during the unfolded protein response: roles of endoplasmic reticulum oxidoreductases, mitochondrial electron transport, and NADPH oxidase. Antioxidants \& Redox Signaling, v. 11, p. 2409-2427, 2009.

SAVAS, M.; YENI, E.; VERIT, A. et al. Acute effect of phosphodiesterase type 5 inhibitor on serum oxidative status and prolidase activities in men with erectile dysfunction. Clinics, v. 65 , p. 1311-1314, 2010.

SAYED, A. A.; COOK, S. K.; WILLIAMS, D. L. Redox balance mechanisms in Schistosoma mansoni rely on peroxiredoxins and albumin and implicate peroxiredoxins as novel drug targets. The Journal of Biological Chemistry, v. 281, p. 17001-17010, 2006.

SAYED, A. A.; SIMEONOV, A.; THOMAS, C. J. et al. Identification of oxadiazoles as new drug leads for the control of schistosomiasis. Nature Medicine, v. 14, p. 407-12, 2008.

SCANDALIOS, J. G. Oxidative stress responses - what have genome-scale studies taught us? Genome Biology, v. 3, p. 1019.1-1019.6, 2002.

SCHAUER, T. M.; NESPER, M.; KEHL, M. et al. Proteassomes from Dictyostelium discoideum: Characterization of structure and function. Journal of Structural Biology, v. 111, p. 135-147, 1993.

SCHNEIDER, O.; ZELCK, U. E. Differential display analysis of hemocytes from schistosome-resistant and schistosome-susceptible intermediate hosts. Parasitology Research, v. 87, p.489-491, 2001.

SCOTT, J. C.; MCMANUS, D. P. Molecular cloning and functional expression of a cDNA encoding the major endoplasmic reticulum-associated calcium-binding protein, calreticulin, from Philippine strain Schistosoma japonicum. Parasitology International, v. 48, p. 35-46, 1999.

SHANG, F.; TAYLOR. Ubiquitin-proteasome pathway and cellular responses to oxidative stress. Free Radical Biology \& Medicine, v. 51, p. 5-16, 2011.

SHAW, K.; HE, C. Y.; ROOS, D. S.; TILNEY, L. G. Proteasome inhibitors block intracellular growth and replication of Toxoplasma gondii. Parasitology, v. 121, p. 35-47, 2000.

SHER, A.; HALL, B. F.; VADAS, M. A. Acquisition of murine major histocompatibility complex gene products by schistosomula of Schistosoma mansoni. The Journal of Experimental Medicine, v. 148, p. 46-57, 1978. 
SHIH, P. C.; LEE, H. H.; LAI, S. C. et al. Efficacy of curcumin therapy against Angiostrongylus cantonensis-induced eosinophilic meningitis. Journal of Helminthology, v. 81, p. 1-5, 2007.

SHRINGARPURE, R.; GRUNE, T.; MEHLHASE, J.; DAVIES, K. J. Ubiquitin conjugation is not required for the degradation of oxidized proteins by proteasome. The Journal of Biological Chemistry, v. 278, p. 311-318, 2003.

SHUHUA, X.; BINGGUI, S.; CHOLLET, J.; TANNER, M. Tegumental changes in adult Schistosoma mansoni harboured in mice treated with praziquantel enantiomers. Acta Tropica, v. 76, p. 107-117, 2000.

SI, X.; WANG, Y.; WONG, J. et al. Dysregulation of the ubiquitin-proteasome system by curcumin suppresses Coxsackievirus B3 replication. Journal of Virology, v. 81, p. 31423150, 2007.

SILES-LUCAS, M. M.; GOTTSTEIN, B. The 14-3-3 protein: a key molecule in parasites as in other organisms. TRENDS in Parasitology, v. 19, p. 575-581, 2003.

SILVA, S. H. Caracterização bioquímica do estresse oxidativo em Schistosoma mansoni. 138p. Tese de Doutorado, apresentada à Faculdade de Medicina de Ribeirão Preto-Universidade de São Paulo, Ribeirão Preto, 2009.

SIMEONOV, A.; JADHAV, A.; SAYED, A. A. et al. Quantitative High-Throughput Screen Identifies Inhibitors of the Schistosoma mansoni Redox Cascade. Plos Neglected Tropical Diseases, v. 2, e. 127, 2008.

SNARY, D.; SMITH, M. A.; CLEGG, J. A. Surface proteins of Schistosoma mansoni and their expression during morphogenesis. European Journal of Immunology, v. 10, p. 573$575,1980$.

SKELLY, P.; SHOEMAKER, C. B. Induction cues for tegument formation during the transformation of Schistosoma mansoni cercariae. International Journal for Parasitology, v. 30, p. 625-631, 2000.

SMITHERS, S. R.; TERRY, R. J. Infection of laboratory host with cercariae of Schistosoma mansoni: and the recovery of adult worms. Parasitology, v. 55, p. 695-700, 1965.

SOARES, C. S. Caracterização molecular e funcional do Ativador do Proteassoma 20S (PA28) em Schistosoma mansoni. 166p. Tese de Doutorado, apresentada à Faculdade de Medicina de Ribeirão Preto-Universidade de São Paulo, Ribeirão Preto, 2011.

SOLIMAN, M. F. M.; IBRAHIM, M. M. Antischistosomal action of atorvastatin alone and concurrently with medroxyprogesterone acetate on Schistosoma haematobium harboured in hamster: surface ultrastructure and parasitological study. Acta Tropica, v.93, p. 1-9, 2005.

SOUZA, C. P.; CALDEIRA, R. L.; DRUMMOND, S. C. et al. Geographical Distribution of Biomphalaria Snails in the State of Minas Gerais, Brazil. Memórias do Instituto Oswaldo Cruz, v. 96, p.293-302, 2001. 
SPERANZA, L.; FRANCESCHELLI, S.; PESCE, M. et al. Phosphodiesterase type-5 inhibitor and oxidative stress. International Journal Of Immunopathology and Pharmacology, v. 21, p. 879-889, 2008.

STADECKER, M. J. The role of T-cell anergy in the immunomodulation of schistosomiasis. Parasitology Today, v. 8, p. 199-204, 1992.

STEINMANN, P.; KEISER, J.; BOS, R. et al. Schistosomiasis and Water resources development: systematic review, meta-analysis, and estimates of people at risk. The Lancet Infectious Diseases, v. 6, p. 411-425, 2006.

TAI, H. C.; BESCHE, H.; GOLDBERG, A. L.; SCHUMAN, E. M. Characterization of the brain $26 \mathrm{~S}$ proteasome and its interacting proteins. Frontiers in Molecular Neuroscience, v. 3, p. 1-19, 2010.

TAMURA, K.; DUDLEY J.; NEI, M.; KUMAR, S. MEGA4: Molecular Evolutionary Genetics Analysis (MEGA) software version 4.0. Molecular Biology and Evolution, v. 24, p. 1596-1599, 2007.

TELES, H. M. S. Distribuição geográfica das espécies dos caramujos transmissores de Schistosoma mansoni no Estado de São Paulo. Revista da Sociedade Brasileira de Medicina Tropical, v. 38, p. 426-432, 2005.

TERRELL, J.; SHIH, S.; DUNN, R.; HICKE, L. A function for monoubiquitination in the internalization of a G Protein-Coupled Receptor. Molecular Cell, v. 1, p. 193-202, 1998.

THANDAVARAYAN, R. J.; GIRIDHARAN, V. V.; SARI, F. R. et al. Depletion of 14-3-3 Protein Exacerbates Cardiac Oxidative Stress, Inflammation and Remodeling Process via Modulation of MAPK/NF- $\kappa B$ Signaling Pathways after Streptozotocin-induced Diabetes Mellitus. Cellular and Physiology and Biochemistry, v. 28, p. 911-922, 2011.

TODA, S.; MIYASE, T.; ARICHI, H. et al. Natural antioxidants. III. Antioxidative components isolated form rhizome of Curcuma longa L. Chemical \& Pharmaceutical Bulletin, v. 33, n. 4, p. 1725-1728, 1985.

TOIVOLA, D. M.; STRNAD, P.; HABTEZION, A.; OMARY, M. B. Intermediate filaments take the heat as stress proteins. Trends Cell Biology, v. 20, p. 79-91, 2010.

TSE, W. K. F.; YOU, M. S.; HO, S. H. K.; JIANG, Y. J. The deubiquitylating enzyme Cops6 regulates different developmental processes during early zebrafish embryogenesis. The International Journal of Development Biology, v. 55, p. 19-24, 2011.

USTRELL, V.; HOFFMAN, L.; PRATT, G.; RECHSTEINER, M. PA200, a nuclear proteasome activator involved in DNA repair. The EMBO Journal, v. 21, p. 3516-3525, 2002.

VAN DER KLEIJ, D.; YAZDANBAKHSH, M. Control of inflammatory diseases by pathogens: lipids and the immune system. European Journal of Immunology, v. 33, p. 2953-2963, 2003. 
VAN DER WERF, M. J.; DE VLAS, S. J.; BROOKER, S. et al. Quantification of clinical morbidity associated with schistosome infection in Sub-Saharan Africa. Acta Tropica, v. 86, p. 125-139, 2003.

VAN HEMERT, M. J.; STEENSMA, H. Y.; VAN HEUSDEN, G. P. 14-3-3 proteins: key regulators of cell division, signalling and apoptosis. BioEssays, v. 23, p. 936-946, 2001.

VERJOVSKI-ALMEIDA, S.; DEMARCO, R.; MARTINS, E. A. et al. Transcriptome analysis of the acoelomate human parasite Schistosoma mansoni. Nature Genetics, v.35, n.2, p.148-157, 2003.

VERMA, R.; ARAVIND, L.; OANIA, R.; MCDONALD, W. H. et al. Role of Rpn11 Metalloprotease in Deubiquitination and Degradation by the $26 \mathrm{~S}$ Proteasome. Science, v. 298, p. 611-615, 2002.

VERMEIRE, J.J.; YOSHINO, T. P. Antioxidant gene expression and function in vitrodeveloping Schistosoma mansoni mother sporocysts: possible role in self-protection. Parasitology, v. 134, p. 1369-1378, 2007.

VIEIRA, P.; MIRANDA, H. P.; CERQUEIRA, M. et al. Latent schistosomiasis in portuguese soldiers. Military Medicine, v. 172, p. 144-146, 2007.

WANG, P.; HEITMAN, J. The cycophilins. Genome Biology, v. 6, p. 1-6, 2005.

WANG, X.; YEN, J.; KAISER, P.; HUANG, L. Regulation of the 26S proteasome complex during oxidative stress. Science Signaling, v. 3, p. ra88-98, 2010.

WATSON, J. L.; RICHARD, H.; YAFLE, P. B. et al. Curcumin causes superoxide anion production and p53-independent apoptosis in human colon cancer cells. Cancer Letters, v. 297, p. 1-8, 2010.

WEBSTER, P. J.; SETA, K. A.; CHUNG, S. C.; MANSOUR, T. E. A cDNA encoding an alpha-tubulin from Schistosoma mansoni. Molecular and Biochemical Parasitology, v. 51, p. 169-170, 1992.

WELCH, W.; SUHAN, J. P. Morphological study of the mammalian stress response: Characterization of changes in cytoplasmic organelles, cytoskeleton, and nucleoli, and appearance of intranuclear actin filaments in rat fibroblasts after heat-shock treatment. The Journal of Cell Biology, v. 101, p. 1198-1211, 1985.

WELKER, S.; RUDOLPH, B.; FRENZEL, E. et al. Hsp12 is an intrinsically unstructured stress protein that folds upon membrane association and modulates membrane function. Molecular Cell, v. 39, p. 507-520, 2010.

WILKINSON, K. D. Regulation of ubiquitin-dependent processes by deubiquitinating enzymes. The FASEB Journal, v. 11, p. 1245-1256, Dec., 1997.

WILLIAMS, D. L.; PIERCE, R. J.; COOKSON, E.; CAPRON, A. Molecular cloning and sequencing of glutathione peroxidase from Schistosoma mansoni, Molecular and Biochemical Parasitology, v. 52, p. 127-130, 1992. 
WILSON, R. A.; BARNES, P. E. The tegument of Schistosoma mansoni: observations on the formation, structure and composition of cytoplasmic inclusions in relation to tegument function. Parasitology, v. 68, p. 239-258, 1974.

WOLF, H. D. From lysosome to proteasome: the power of yeast in the dissection of proteinase function in cellular regulation and waste disposal. Cellular and Molecular Life Sciences, v. 61, p. 1601-1614, 2004.

WU, H. M.; CHI, K. H.; LIN, W. W. Proteasome inhibitors stimulate activator protein-1 pathway via reactive oxygen species production. FEBS Letters, v. 526, p. 101-105, 2002.

WU, X. J.; SABAT, G.; BROWN, J. F. et al. Proteomic analysis of Schistosoma mansoni proteins released during in vitro miracidium-to-sporocyst transformation. Molecular \& Biochemical Parasitology, v. 164, p. 32-44, 2009.

WYRSCH, P.; BLENN, C.; BADER, J.; ALTHAUS, F. R. Cell death and autophagy under oxidative stress: Roles of Poly(ADP-Ribose) polymerases and $\mathrm{Ca}^{2+}$. Molecular and Cellular Biology, v. 32, p. 3541-3553, 2012.

YAMANAKA, K.; ISHIKAWA, H.; MEGUMI, Y. et al. Identification of the ubiquintprotein ligase that recognizes oxidized IRP2. Nature Cell Biology, v. 5, p. 336-340, 2003.

YAO, T.; COHEN, R. E. A cryptic protease couples deubiquitination and degradation by the proteasome. Nature, v. 419, p. 403-407, 2002.

YOU, B. R.; PARK, W. H. Proteasome inhibition by MG132 induces growth inhibition and death of human pulmonary fibroblast cells in a caspase-independent manner. Oncology Reports, v. 25, p. 1705-1712, 2011.

YOUNG, J. C.; AGASHE, V. R.; SIEGERS, K.; HARTL, F. U. Pathways of chaperonemediated protein folding in the cytosol. Nature Reviews Molecular Cell Biology, v. 5, p. 781-91, 2004.

ZELCK, U. E.; VON JANOWSKY, B. Antioxidant enzymes in intramolluscan Schistosoma mansoni and ROS-induced changes in expression. Parasitology, v. 128, p. 493-501, 2004.

ZHANG, D. (2009). Noncatalytic Effect of the Ubiquitin Ligase Hul5 on Proteasome Function. Dissertação apresentada à Divisão de Ciências Médicas, subárea de Células e Biologia do Desenvolvimento, Universidade de Harvard em Cambridge, Massachusetts, para obtenção do título de Doutor em Filosofia.

ZINSZNER, H.; KURODA, M.; WANG, X. et al. CHOP is implicated in programmed cell death in response to impaired function of the endoplasmic reticulum. Genes \& Development, v. 12, p. 982-995, 1998.

YOSHINO, T. P.; LAURSEN, J. R. Production of Schistosoma mansoni daughter sporocysts from mother sporocysts maintained in synxenic culture with Biomphalaria glabrata embryonic (Bge) cells. The Journal of Parasitology, v. 81, p. 714-722, 1995. 